\title{
CHANGES IN TROPHIC NICHES OF ORIBATID MITES WITH TRANSFORMATION OF TROPICAL RAINFOREST SYSTEMS - FROM RAINFOREST INTO RUBBER AND OIL PALM PLANTATIONS IN SUMATRA, INDONESIA
}

\author{
Dissertation \\ For the award of the degree \\ “Doctor rerum naturalium" (Dr.rer.nat.) \\ of the Georg-August-Universität Göttingen
}

within the doctoral program Biodiversity and Ecology

of the Georg-August University School of Science (GAUSS)

submitted by

M.Sc. Alena Krause

from

Gifhorn

Göttingen, 2020 


\section{Thesis Committee}

Stefan Scheu / Animal Ecology, J.F. Blumenbach Institute of Zoology and Anthropology, Göttingen (Name of Department / Research Group, Institution)

Marko Rohlfs / Institute of Ecology, Population and Evolutionary Biology, Bremen

(Name of Department / Research Group, Institution)

Mark Maraun / Animal Ecology, J.F. Blumenbach Institute of Zoology and Anthropology, Göttingen

(Name of Department / Research Group, Institution)

\section{Members of the Examination Board}

Reviewer Stefan Scheu / Animal Ecology, J.F. Blumenbach Institute of Zoology and Anthropology, Göttingen

(Name of Department / Research Group, Institution)

Second Reviewer Marko Rohlfs / Institute of Ecology, Population and Evolutionary Biology, Bremen (Name of Department / Research Group, Institution)

Additional Reviewer (if applicable)

(Name of Department / Research Group, Institution)

Further member of the Examination Board

Mark Maraun / Animal Ecology, J.F. Blumenbach Institute of Zoology and Anthropology, Göttingen

(Name of Department / Research Group, Institution)

Christoph Bleidorn / Animal Evolution and Biodiversity / J.F. Blumenbach Institute of Zoology and Anthropology, Göttingen

(Name of Department / Research Group, Institution)

Holger Kreft / Biodiversity, macroecology, biogeography / Faculty of Forest Sciences and Forest Ecology, Göttingen

(Name of Department / Research Group, Institution)

Klaus Hövemeyer / Animal Ecology, J.F. Blumenbach Institute of Zoology and Anthropology, Göttingen (Name of Department / Research Group, Institution) 
"Soil provides the foundation of human existence,

[...]." from "Soil Fauna Assemblages, Global to Local Scales" from Uffe N. Nielsen 



\section{Content}

Summary

General Introduction

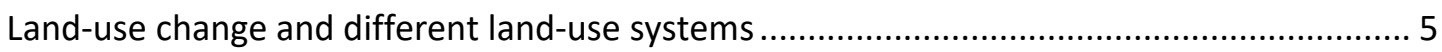

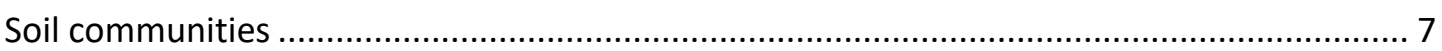

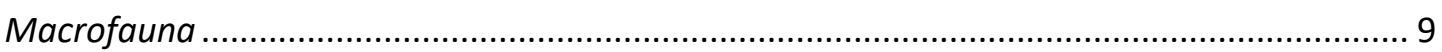

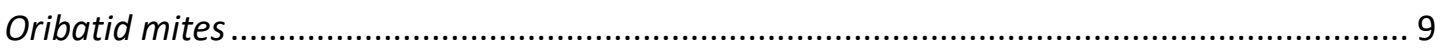

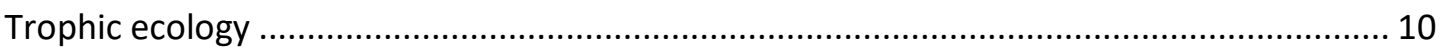

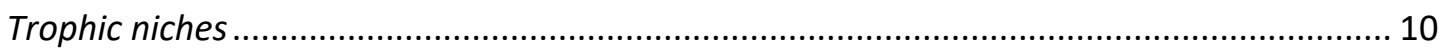

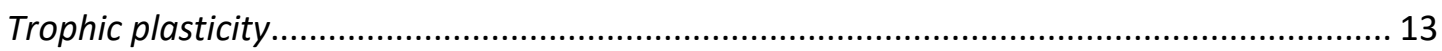

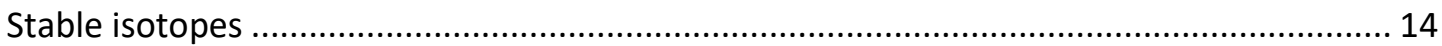

Management of oil palm plantations and the 'Biodiversity Enrichment Experiment'

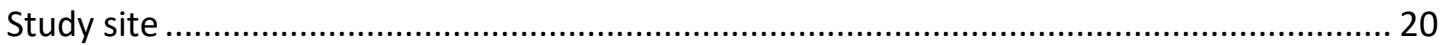

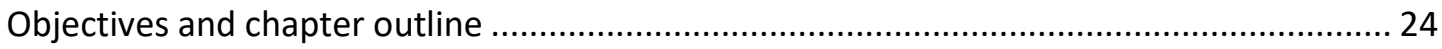

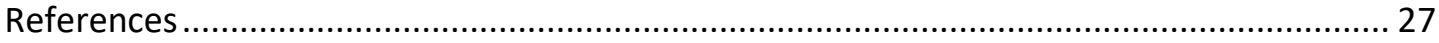

Shift in trophic niches of soil microarthropods with conversion of tropical rainforest into plantations as indicted by stable isotopes $\left({ }^{15} \mathrm{~N},{ }^{13} \mathrm{C}\right)$

Abstract

Introduction

Material and Methods 44

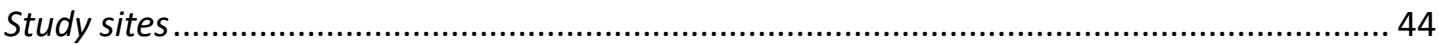

Sampling, extraction and species determination .............................................................. 45

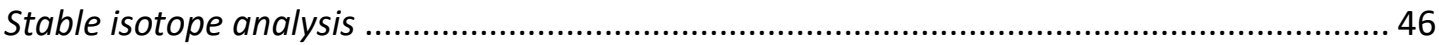

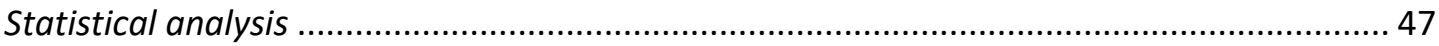

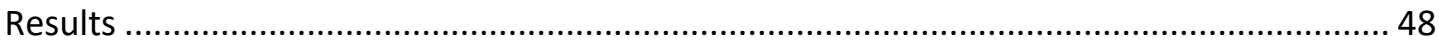

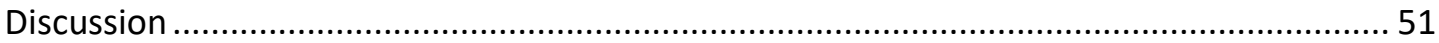

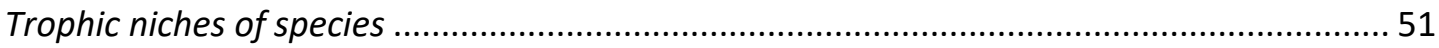

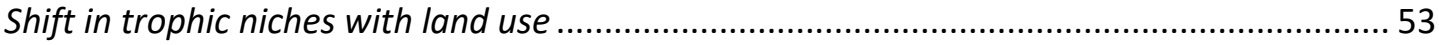

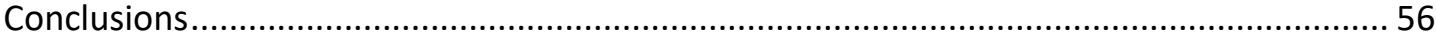

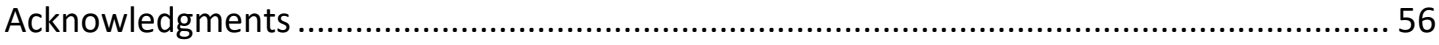

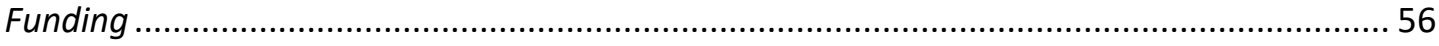

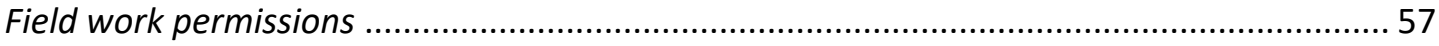

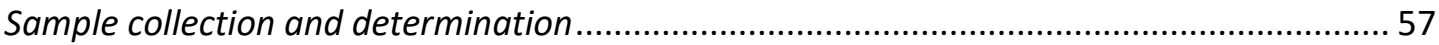

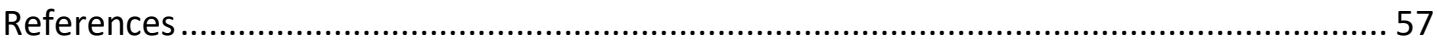

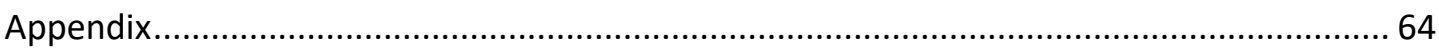


Variation in community level trophic niches of soil microarthropods with conversion of tropical rainforest into plantations systems as indicted by stable isotopes $\left({ }^{15} \mathrm{~N},{ }^{13} \mathrm{C}\right)$.

Abstract 76

Introduction 78

Material and Methods 82

Study sites. 82

Sampling, extraction and species determination 83

Stable isotope analysis 83

Statistical analysis 84

Results 88

Trophic structure 88

One-dimensional metrics. 89

Multidimensional metrics 91

Discussion .93

One-dimensional metrics.... .93

Multidimensional metrics. .97

Conclusions 98

Acknowledgments .99

Funding .99

Field work permissions 99

Sample collection and determination 100

References 100

Appendix. 106

Response of soil animal communities to tree diversity enrichment of oil palm plantations... 1

Introduction 132

Material and Methods 135

Study sites 135

Sampling, extraction and species determination 136

Statistical analysis

Results

Abundance of total macro- and mesofauna.

Richness of macro- and mesofauna taxa

Community structure.

Discussion

Abundance of macro- and mesofauna

Richness of macro- and mesofauna taxa 


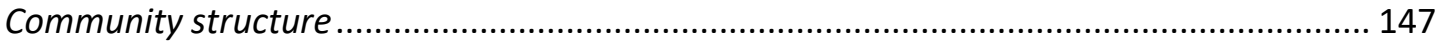

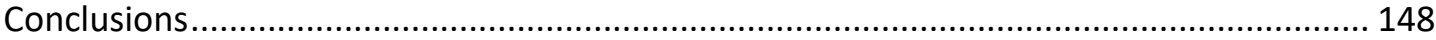

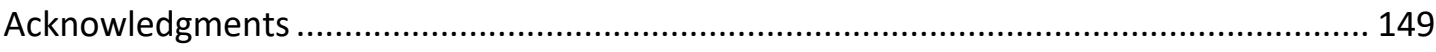

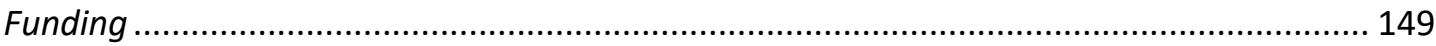

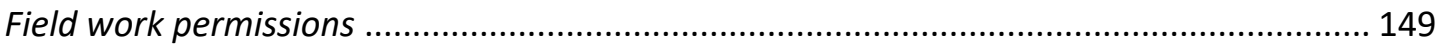

Sample collection and determination ....................................................................... 150

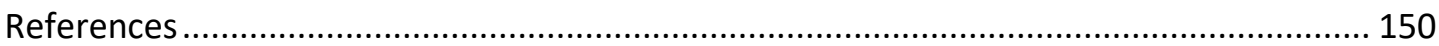

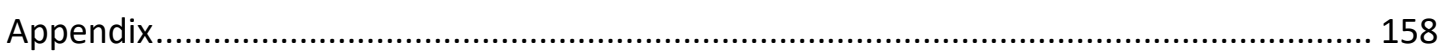

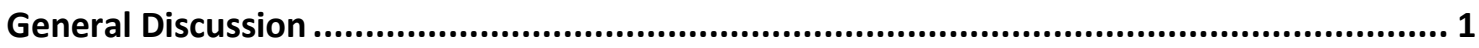

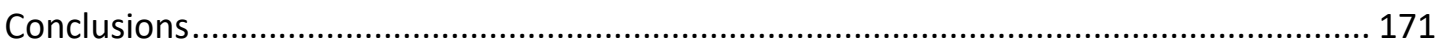

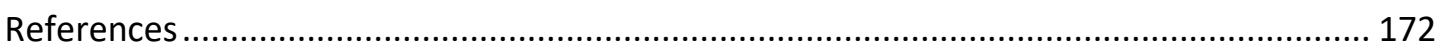

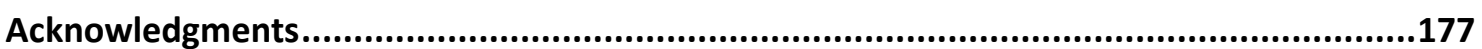

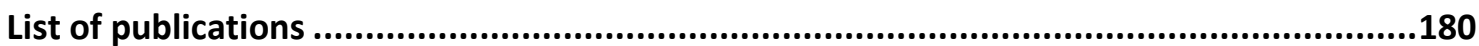

Thesis declaration ...........................................................................................181

Declaration of the author's own contribution to manuscripts with multiple authors........ 181

Plagiarism declaration .............................................................................183

Poster and oral presentation ................................... Fehler! Textmarke nicht definiert. 



\section{Summary}

During the last decades especially tropical regions suffered from degradation as well as transformation of landscapes into different land-use systems. Logged rainforest sites in Southeast Asia are often transformed into cash crop monocultures, especially oil palm and acacia plantations. Such transformation processes may threaten the functioning of ecosystems with the worldwide highest biodiversity and endemism. Effects of this transformation and degradation have mainly been studied for aboveground organisms whereas effects on the functioning and composition of soil invertebrate communities are little studied.

This thesis focuses on the effects of land-use transformation along a land-use gradient, i.e. from secondary rainforest to plantations (jungle rubber, rubber and oil palm monoculture), on microarthropod communities, using oribatid mites as model organisms. Further, I investigated the effect of management strategies within oil palm plantations on macro- and mesofauna soil animals. The field studies were conducted within the interdisciplinary project "Ecological and socioeconomic functions of tropical lowland rainforest transformation systems (Sumatra, Indonesia)" (EFForTS), established in Jambi Province, southwest Sumatra (Indonesia) in 2013.

In the first study, presented in Chapter 2, we investigated shifts in trophic niches of six soil-living oribatid mite species and their possible trophic plasticity with the conversion of lowland secondary rainforest into plantation systems (jungle rubber, rubber and oil palm monoculture plantations) in two regions of southwest Sumatra, Indonesia. Therefore, stable isotope ratios $\left({ }^{13} \mathrm{C} /{ }^{12} \mathrm{C}\right.$ and $\left.{ }^{15} \mathrm{~N} /{ }^{14} \mathrm{~N}\right)$ of single oribatid mite individuals were measured and, subsequently, we calculated shifts in stable isotope niches with changes in 
land-use systems. On the basis of significant changes in stable isotope ratios in three of six studied oribatid mite species this study demonstrated that these species are able to shift their trophic niche in land-use transformation systems. Those shifts were either due to changes in trophic level (indicated by $\delta^{15} \mathrm{~N}$ values) or due to changes in the use of basal resources (indicated by $\delta^{13} \mathrm{C}$ values) or both. Notably, the shifts were most pronounced between more natural systems (secondary rainforest and jungle rubber) on one side and monoculture plantation systems (rubber and oil palm plantations) on the other side; thereby indicating that the shifts were related to land-use intensity.

In the second study, presented in Chapter 3, we investigated shifts in community-level trophic niches of soil-living oribatid mites with the conversion of lowland secondary rainforest into plantation systems (jungle rubber, rubber and oil palm monoculture plantations) in two regions of southwest Sumatra, Indonesia. Therefore, stable isotope ratios $\left({ }^{13} \mathrm{C} /{ }^{12} \mathrm{C}\right.$ and $\left.{ }^{15} \mathrm{~N} /{ }^{14} \mathrm{~N}\right)$ of pooled oribatid mite species were measured, and subsequently, we calculated shifts in community-level trophic niche with transformation of land-use systems. This study demonstrated that the community-level trophic niche of oribatid mites is larger in rainforests than in plantation systems, suggesting that the conversion of rainforest into plantation systems is associated with reduced availability of litter resources. Results of this study further demonstrated that community-level trophic niches in rainforest and jungle rubber are separated from those in monoculture plantation systems, indicating again that the trophic niche of oribatid mite communities shifts markedly with land-use change. Additionally, ${ }^{15} \mathrm{~N} /{ }^{14} \mathrm{~N}$ ratios of oribatid mite communities indicated that the diet of microarthropods shifts towards predation and/or scavenging with changing land-use systems. This may be due to the limited amount of litter and its 
low quality in rubber and oil palm plantations. Further, exceptionally low ${ }^{13} \mathrm{C} /{ }^{12} \mathrm{C}$ ratios of oribatid mite communities in rubber plantations suggest that certain oribatid mite species in these land-use systems use resources which are lacking in the other studied ecosystems. Oribatid mite communities in plantation systems present an unusual high functional richness and uniqueness compared to natural systems.

The results of the first two studies demonstrated that soil-living oribatid mite species are able to adapt to changing land-use systems and do not suffer to the same extent from these changes as many aboveground species. The third experiment, presented in Chapter 4, focused on investigating the effect of 'tree islands' of different size $(5 \times 5,10 \times 10,20 \times$ 20 and $40 \times 40 \mathrm{~m})$ and diversity level of planted native trees (0, 1, 2, 3 and 6) within oil palm plantations. Here we investigated the response of meso- and macrofauna species to the establishment of 'tree islands' three years after the experiment started. Neither the different diversity levels of native tree species nor the plot size significantly affected the abundance of soil invertebrate taxa. However, richness of soil invertebrate taxa was positively affected in 'tree islands' of diversity level 2 . The result demonstrated that the diversity and abundance of plant communities little affect the structure and diversity of soil invertebrates three years after establishment suggesting soil invertebrates respond with a pronounced time lag to the experimental manipulations. Overall, by investigating the trophic ecology of oribatid mites and their response to changes in land-use systems the results of this thesis improved the understanding of how soil communities and individual species respond to the conversion of rainforest into intensively managed agricultural systems. 

Chapter I

\section{General Introduction}
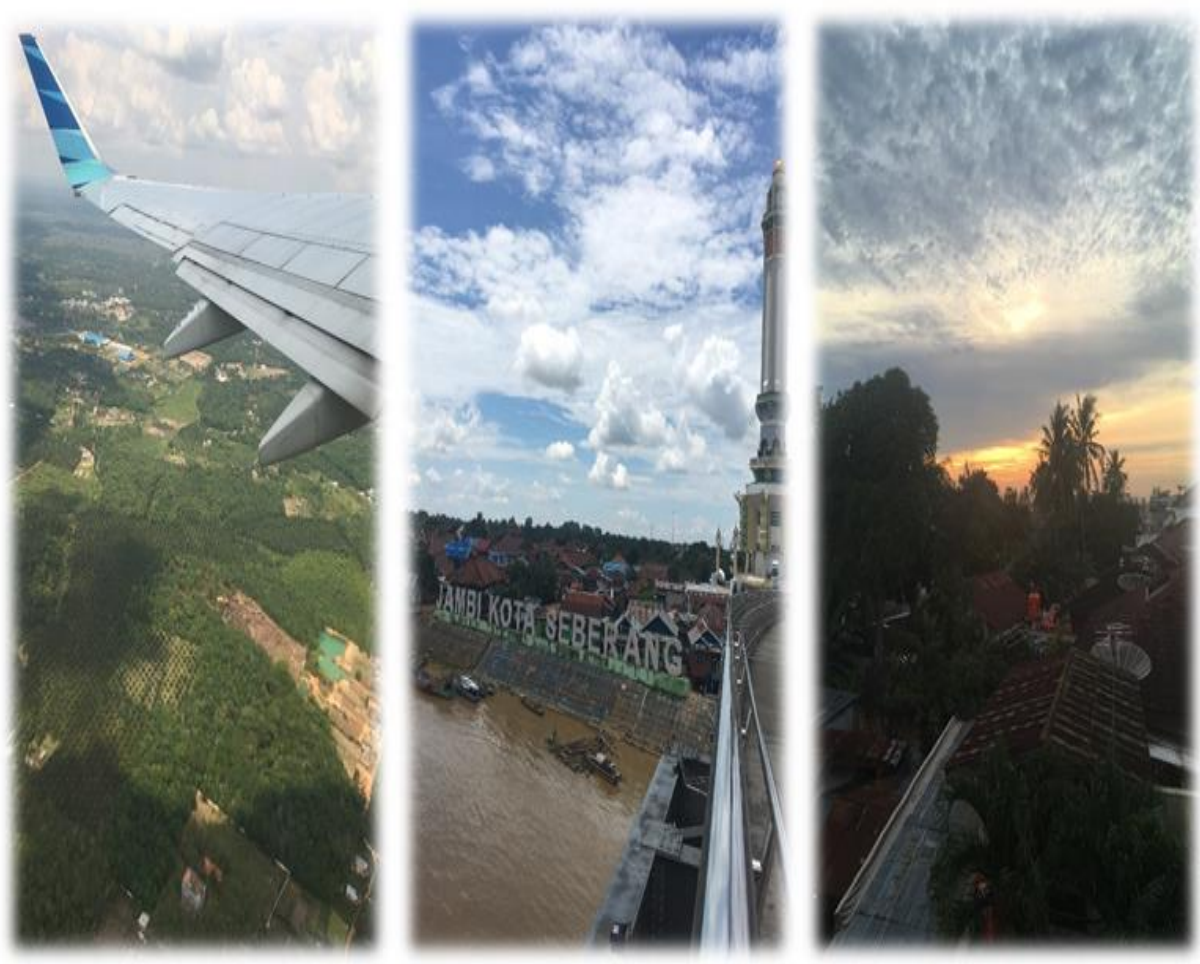



\section{Land-use change and different land-use systems}

The worldwide rapidly growing human population is leading to a rising need for food, fuel and fiber, and therefore transformation as well as degradation of landscapes is increasing (Dirzo and Raven, 2003; Foley et al., 2005; Gibbs et al., 2010; Newbold et al., 2015). It is estimated, that the worldwide population size will increase to 9.7 billion by 2050 (UN, 2015) leading to an increase in the demand for food by 70 \% (Godfray et al., 2010). These demands lead to high pressure on ecosystems worldwide, leading to a higher conversion of natural ecosystems into plantations, with more pressure on the production and yield of those agricultural systems (Godfray et al., 2010; Lambin and Meyfroidt, 2011; Tscharntke et al., 2012). Human activity strongly impacts natural ecosystems, directly e.g., via building infrastructure and houses, as well as indirectly e.g., via climate change and nutrient deposition (DeFries et al., 2004; Foley et al., 2005, 2011). About $40 \%$ of the terrestrial surface has been transformed into agricultural systems, with an increasing proportion being degraded resulting in habitat loss and desertification e.g., due to erosion, due to construction of infrastructure and additionally due to human behavior (Bridges and Oldeman, 1999; Reynolds et al., 2007; Foley et al., 2011; Pavao-Zuckerman and Sookhdeo, 2017; Francini et al., 2018). This is mainly caused by high levels of fertilizer application and atmospheric deposition. Additionally, external input of nitrogen and phosphorus has been increasing since the $19^{\text {th }}$ centuries (Peñuelas et al., 2012).

In the last decades, especially tropical regions suffered from degradation and transformation into land-use systems, such as oil palm or rubber plantations (Sodhi et al., 2010; Wilcove et al., 2013; Meijide et al., 2018). In South East Asia these transformations are threatening ecosystems with the highest biodiversity and endemism worldwide 
(Jones, 2013). Since the mid-20 $0^{\text {th }}$ century rainforests in Southeast Asia have been logged, often followed by the transformation of logged sites into cash crop monocultures, such as rubber, oil palm and acacia plantations (Koh and Wilcove, 2008; Wilcove and Koh, 2010; Drescher et al., 2016). The process of expanding as well as intensification of agricultural landscapes poses the greatest threat to biodiversity (Tilman et al., 2001; Donald, 2004; Green et al., 2005). In my thesis, a gradient of different land-use systems was studied. Rainforest sites were represented by 'primary degraded forest', classified after Margono (2014). Jungle rubber land-use systems were rubber agroforests systems (Hevea brasiliensis) that resemble secondary rainforest, where naturally occurring species of different trees were included (Beukema et al., 2007). Rubber monoculture plantations exclusively include rubber trees (Hevea brasiliensis), and oil palm monoculture plantations exclusively include oil palm trees (Elaeis guineensis) (Drescher et al., 2016).

One of the agricultural land-use systems that is rapidly increasing are vegetable oils (Clay, 2013), with oil palm as one of the most quickly expanding crops (Carter et al., 2007; Fitzherbert et al., 2008). Additionally, biofuel markets and rising food demand in the European Union as well as in Indonesia, India and China result in increasing global oil palm production, currently by about $9 \%$ each year (European Comission, 2006; Clay, 2013), with Malaysia and Indonesia as the main producers of palm oil (Koh and Wilcove, 2007). Palm oil belongs to one of the versatile oils, which has not only many different functions and therefore is widely used but it is also one of the most efficient crops worldwide (Zimmer, 2010; Ashraf et al., 2018). Moreover, it is the crop which produces the highest yield per land area (Zimmer, 2010; Ashraf et al., 2018). 
Transformation of rainforest into agricultural systems strongly increased in Indonesia. Commercial oil palm cultivation in Indonesia started in 1911, with Sumatra as starting point (Abdullah and Nobukazu, 2007; Corley et al., 2008). After the 1980s oil palm plantations were also established in other parts of Indonesia (Abdullah and Nobukazu, 2007; Corley et al., 2008). Oil palm as well as rubber plantations often were established on rainforest sites which were already logged or degraded by fire (Curran et al., 2004; Dennis et al., 2005; Fitzherbert et al., 2008; Drescher et al., 2016). Nevertheless, conversion of rainforest into oil palm plantations may account for $16 \%$ of recent deforestation in Indonesia (Fitzherbert et al., 2008), whereas the conversion of rainforest into rubber plantations and therefore the production of natural rubber has increased more than $50 \%$ since 2000 (Ahrends et al., 2015).

In 2012, 0.84 million hectares rainforest were converted into agricultural systems in Indonesia, the highest rate worldwide (Margono et al., 2014; Drescher et al., 2016). One of the highest losses of primary forest occurred in Sumatra (Indonesia), with 0.40 million hectares per year between 2009 and 2011 (Laumonier et al., 2010; Miettinen et al., 2011; Margono et al., 2014). Oil palm plantations are known to hold less than half as many vertebrate species as primary rainforest (Danielsen et al., 2009). However, the effects of conversion of rainforest into plantation systems have been rarely studied for belowground arthropods (Newbold et al., 2015).

\section{Soil communities}

Agricultural production essentially depends on soil, and soils therefore are important for human welfare, e.g. food, fiber and fuel production (Nielsen, 2019). In fact, one of the key 
factors for the survival of humankind relies on soils and soil processes which are based on the activity of soil biota. However, until today understanding of the structure of soil communities and the functioning of soil systems still is limited.

Up to $90 \%$ of the primary production of plants enters the soil system as leaf/wood detritus and rhizodeposits (McNaughton et al., 1989; Bardgett, 2005). Therefore, decomposition, together with primary production, is the most important process for terrestrial ecosystems. The presence or absence of specific soil animal species can modify the structure and functioning of soil systems, such as the turnover of organic matter and nutrient cycling (Bardgett, 2005; Nielsen et al., 2015). Additionally, certain functional types of soil fauna may enhance soil functioning or even modify soil food webs (Brussaard et al., 2007). Soil arthropods are part of any soil but the abundance and diversity varies strongly between different ecosystems, even within small spatial scales (Ettema and Wardle, 2002). This high spatial heterogeneity in the structure of soil communities is likely due to variations in biotic as well as abiotic factors, e.g. climate and litter type (Coûteaux, Marie-Madeleine Bottner and Berg, 1995; Wardle et al., 2006; Berg and McClaugherty, 2008). Soil fauna is highly diverse and can be divided into functional size classes of micro, meso- and macrofauna (Swift et al., 1979). The trophic differentiation of micro- and macrofauna species has been long accepted and recent evidence based on stable isotope analysis underlined these assumptions (Potapov et al., 2019), whereas mesofauna taxa usually were taken as uniform trophic guild (De Ruiter et al., 1993; Berg and Bengtsson, 2007; Moore and de Ruiter, 2012). Contrasting this assumption, recent studies based on stable isotopes documented a variety of trophic niches and trophic levels within major groups of mesofauna (Schneider et al., 2004; Chahartaghi et al., 2005; Maraun et al., 2011; 
Klarner et al., 2013). As Potapov et al. (2019) stated, different species within the same taxonomic group can belong to different trophic levels and may therefore provide different ecosystem services. The most abundant taxa for soil mesofauna are Collembola and Acari (Petersen and Luxton, 1982). Both groups represent a wide range of different life history traits, trophic positions, and therefore are likely to affect ecosystem functions in a variety of ways (Scheu, 2002; Schneider et al., 2004; Nielsen, 2019).

\section{Macrofauna}

Macro- and megafauna, due to their larger size, have different and more pronounced effects on ecosystems (Lal, 1988; Folgarait, 1998; Migge-Kleian et al., 2006). They play an important role for litter fragmentation as well as displacement, produce large amounts of faecal pellets and can enhance decomposition processes (David, 2014). Many macro- and megafauna species are considered ecosystem engineers, since they can modify the environment strongly, e.g. by feeding, burrowing, and the production of faecal pellets (Bonachela et al., 2015; Parr et al., 2016; Ashton et al., 2019). Additionally, macro- and megafauna produce lasting imprints on the environment, including the change of soil structure as well as organic matter distribution, and thus influence soil properties, soil biological assemblages, element cycling and ecosystem functioning more than other soil fauna (Migge-Kleian et al., 2006; Parr et al., 2016; Ashton et al., 2019; Nielsen, 2019).

\section{Oribatid mites}

With about 11,000 described species (Subías et al., 2018), and the true number of species likely exceeding 50,000 (Walter and Proctor, 2013), oribatid mites are the most diverse 
soil microarthropods. Oribatid mites colonize a wide range of different habitats, e.g. temperate to tropical regions, deserts, tundras and aquatic habitats (Krantz et al., 2009). Densities of oribatid mites can reach up to $200,000 \mathrm{ind} . / \mathrm{m}^{2}$ in forest soils of temperate regions whereas in tropical regions densities typically are in the range of $30,000-40,000$ ind./m² (Maraun and Scheu, 2000; Maraun et al., 2007; Scheu et al., 2008). Oribatid mites are trophically highly diverse and span over about three to four trophic levels, including lichen and algae feeders, fungal feeders, primary and secondary decomposer as well as predators/scavengers (Maraun et al., 2004; Schneider et al., 2004; Illig et al., 2005; Erdmann et al., 2007). Different life history traits, e.g. low fertility, slow development and long life cycles, leave oribatid mites sensitive to soil conditions and thereby changes in environmental conditions (Behan-Pelletier, 1999). Due to high population density and species richness oribatid mites have been proposed as indicator organisms for soil health (Bedano et al., 2011) and land use (Zhao et al., 2013), reflecting impacts of land use intensification, especially in tropical rainforest systems (Migge-Kleian et al., 2007; Gan et al., 2014; Hasegawa et al., 2014).

\section{Trophic ecology}

\section{Trophic niches}

One of the most important concepts in ecology is the niche concept (Hutchinson, 1959; Chase and Leibold, 2003). Niche differentiation is considered to be the basis for species co-existence (Tokeshi, 2009). Organisms not only interact as an ecological 'guild', e.g. group of taxa that use the same class of resources in a comparable way (Root, 1967), or due to trophic relations, e.g. predator-prey interactions which can shape the process of 
evolution but also contributes to the complexity of communities (Tokeshi, 2009), but also due to the use of habitats (Tokeshi, 2009). Therefore, two types of niches are differentiated, the 'fundamental niche' (Hutchinson, 1978) and the realized niche, describing the 'role' of the species within a community, focusing mainly on its trophic position (Elton, 1927). The fundamental niche is defined as the niche occupied by species in the absence of competition or other biotic interactions, whereas the realized niche is defined as the niche space occupied in presence of competition and biotic factors. Based on the interactions between species and/or populations different mechanisms are responsible for these interactions or effects on other organisms (Abrams, 1987). Six different interaction types are commonly distinguished, i.e. competition, predation, herbivory, parasitism, diseases and mutualism (Krebs, 1994). One of the important factor is the availability of resources for species, forming the basis of competitive interactions (White, 1993). There are two different types of competition as defined by Birch (1957). First, resource competition occurs when organisms (from the same or different species) indirectly interact by using the same resources which is scarce. Second, interference competition occurs when organisms directly interact for access to resources. Competition therefore can lead to changes in the population size of the competing species (LotkaVolterra equation; Lotka, 1925; Volterra, 1926) or lead to one species 'winning' and the extinction of the other or co-existing of species, based on the availability of resources (Tilman, 1977, 1986).

There are different niche-related concepts. The first is environmental filtering, which implies that communities are assembled according to similarity of niches (Vellend, 2010; Kraft et al., 2015). The second is based on competition between species leading to niche 
differentiation of species within communities (Macarthur et al., 1967; Violle et al., 2011), implying that the structure of communities evolves with the co-existence of species in a stable environment (Korotkevich et al., 2018). The trophic niche as dimension of the ecological niche implies effects of species on other species within communities, thereby being related to the role within the ecosystem of those species (Leibold, 1995; Chase and Leibold, 2003). Species with a broader trophic niche are predicted to more easily invade existing communities than those with a narrower niche, and to survive disturbances more easily (Bommarco et al., 2010; Dammhahn et al., 2017). There are few studies focusing on changes in trophic-niches in disturbed habitats, most of the conducted studies focused on the response of individual species and not the community (Korotkevich et al., 2018). Studies focusing on trophic-niche shifts at the community level are mostly based on aquatic systems (di Lascio et al., 2013; Hansen et al., 2018). One of the few studies analyzing shifts in trophic niches of soil invertebrates to changes in land use systems, regarding the response of individual species is Krause et al. (2019), with the results indicating trophic plasticity in oribatid mite species. Further, focusing on the community level Klarner et al. (2013) investigated the trophic structure of Mesostigmata in beech stands in Central Germany and showed that Mesostigmata predominantly feed on secondary decomposer. Notably, closely related taxa often had very different stable isotope values suggesting that trophic niche partitioning allowed the coexisting of morphological similar species (Klarner et al., 2013). 


\section{Trophic plasticity}

Trophic plasticity allows animals to react to changing environmental conditions, such as global warming, intensified land use or flooding. Organisms with generalist feeding habits are more flexible regarding their diet and therefore may be less affected by changing environmental conditions as compared to organisms with a more narrow diet. Until today, trophic plasticity mostly has been investigated in aquatic taxa, mainly in fish (Bowen and Allanson, 1982; Almeida et al., 2012; Drymon et al., 2012) and snails (Riera, 2010). Predominantly, these studies focused on changes in morphology and behavior due to changing environmental factors rather than on trophic plasticity. Juvenile Tilapiu mossumbica (Cichlidae. Teleostei) move daily from deep offshore waters to shallow littoral areas for feeding and back (Bowen and Allanson, 1982). This movement is linked to changes in physical and biological features of the littoral environment and therefore varies in time. Moreover, with changes in the lake water level there were also changes in the diet and behavior. Micropterus salmoides (Percomorphaceae; Teleostei) is known as an invasive species and trophic plasticity likely contributes to the success as invasive species (Almeida et al., 2012). Another important factor for trophic plasticity in one species could be regional variation of diet as shown for Rhizoprionodon terraenovae (Carcharhinidae, Selachii) as well as for Hydrobia ulvae (Hydrobiidae, Gastropoda) (Riera, 2010; Drymon et al., 2012). Leal et al. (2015) showed that tropic plasticity can also be influenced by symbiosis.

Only few studies investigated the trophic plasticity in the field in soil organisms and very few considered changes in trophic niches with changes in land use. One of the few field studies existing showed that centipede predators are able to switch their diet from feeding 
on secondary decomposer in rainforest to less ${ }^{13} \mathrm{C}$ enriched prey in oil palm plantations (Klarner et al., 2017). Results of another study on predation of centipedes showed that the management of different forest types in Germany does not affect the prey spectrum, but it varies with the depth of the litter layer and soil pH (Günther et al., 2014). Another study focused on oribatid mites from temperate systems (Gan et al., 2014), where oribatid mites were found to suffer from environmental changes, since those animals are assumed to be specialized regarding their diet (according to their ${ }^{15} \mathrm{~N}$ and ${ }^{13} \mathrm{C}$ signature) and therefore likely to go extinct with changes in environmental conditions. Generally, laboratory studies with oribatid mites suggest that their food preferences are innate and little affected by learning (Brückner et al., 2018).

\section{Stable isotopes}

It is difficult to study the trophic interactions of soil animals (Pollierer et al., 2009). One major problem is the structure of the soil. Soil structure, e.g. pore size distribution, water infiltration, water holding capacity and/or chemical characteristic have a direct impact on the abundance and distribution of soil animals (Ducarme et al., 2004; Nielsen et al., 2008; Nielsen, 2019). Soil animals are often small, displace complex trophic levels and are not easy to identify (Sunderland et al., 2005; Potapov et al., 2019). Further, the feeding behavior of soil animals is also affected by biotic and abiotic soil conditions (Traugott et al., 2013). Models and simulations can provide insights into dynamics and structure of food webs, however, it is important to validate the trophic position of species/taxa with real-world data (Finlay-Doney and Walter, 2012). Recently, significant methodological advantages have been made studying trophic interactions (Traugott et al., 2013). Some of 
the important methods for studying trophic interactions are stable isotope and fatty acid analysis which allow to detect resource allocation (Ruess and Chamberlain, 2010; Boecklen et al., 2011), whereas DNA-based techniques allow to link feeding interactions to taxonomic positions (Gariepy et al., 2007; Symondson, 2012). Advantages of DNA-based methods include for example that multiple individual samples can be pooled in e.g., NGSbased techniques (Deagle et al., 2009) or gut-content analysis (Zaidi et al., 1999), however, there also are disadvantages. One of the most critical one is the high sensitivity of PCR, which may not only detect food and predator DNA but also DNA of contaminations (Traugott et al., 2013). Fatty acid analysis can be used to detect different diet due to specific fatty acid signatures of bacteria, fungi, algae and plants which animals are not able to synthesize (Ruess and Chamberlain, 2010). Fatty acids of consumers to a large extent originate from their diet as they are assimilated and incorporated without major change ('dietary routing'; Ruess and Chamberlain, 2010; Traugott et al., 2013). Nevertheless, fatty acid analysis also has disadvantages, one is the intermediate specificity as well as the metabolic modification of fatty acid signatures in the consumer (Traugott et al., 2013). Stable isotope analysis is one of the most valuable tool for studying food webs (Ehleringer et al., 1986; Fry, 2006; Boecklen et al., 2011; Traugott et al., 2013) and has been adopted for long to also study soil food webs (Ponsard and Arditi, 2000; Scheu and Falca, 2000; Scheu, 2002). One of the disadvantages of this method is the rather large amount of material needed hampering the analysis of small species, this, however, has been overcome in part by recent advances in the analytical procedure (Langel and Dyckmans, 2014). 
Natural variations in ${ }^{15} \mathrm{~N} /{ }^{14} \mathrm{~N}$ and ${ }^{13} \mathrm{C} /{ }^{12} \mathrm{C}$ ratios allow to evaluate the trophic structure of animal communities (DeNiro and Epstein, 1978; Minagawa and Wada, 1984; Wada et al., 1991). Stable isotope signatures of animal tissue provide information about the trophic position and trophic links of animals as well as on the basal resource used (Tiunov, 2007; Traugott et al., 2013). The use of stable isotopes for analyzing the structure of food webs started in the 1970s (DeNiro and Epstein, 1978) and increased ever since (Ehleringer et al., 1986; Fry, 2006; Boecklen et al., 2011). ${ }^{13} \mathrm{C}$ ratios are used to trace basal food resources, since ${ }^{13} \mathrm{C} /{ }^{12} \mathrm{C}$ ratios stay rather constant through food chains (Post, 2002). By contrast, isotopic fractioning leads to an enrichment in ${ }^{15} \mathrm{~N}$ from prey to consumer by $3.4 \%$ per trophic level (Post, 2002; Martínez Del Rio et al., 2009), thereby ${ }^{15} \mathrm{~N}$ values allow ascribing animals to different trophic levels and reflecting their feeding habits (DeNiro and Epstein, 1978; Kreipe et al., 2015). However, estimation of the trophic position requires an isotopic baseline since ${ }^{15} \mathrm{~N} /{ }^{14} \mathrm{~N}$ and ${ }^{13} \mathrm{C} /{ }^{12} \mathrm{C}$ ratios vary in primary producers in time and space (Jardine et al., 2006). To establish the appropriate baseline, it is necessary to measure the isotopic signatures of carbon sources within the study site, i.e. by measuring the stable isotope ratio of leaf litter and soil (Casey and Post, 2011). Comparing isotope signatures of animals and the basal resource is a powerful tool to understand trophic interactions and dynamics of organic matter in soil (Potapov et al., 2019), processes otherwise very difficult to study in-situ (Tiunov, 2007). Dead plant material either is used for decomposition or incorporated into soil organic matter, processes which are essentially driven by the activity and/or interactions between soil organisms (De Ruiter et al., 1993; Nielsen et al., 2011; Filser et al., 2016; Potapov et al., 2019). 
Stable isotopes cannot only be used to study the structure of food webs, but also to analyze the trophic ecology of specific taxonomic groups (Scheu and Falca, 2000; Halaj et al., 2005; Maraun et al., 2007, 2011; Tiunov, 2007). In soil, stable isotopes have been used to investigate trophic niches of species of earthworms, (Martin et al., 1992), ants (Blüthgen et al., 2003), but also smaller animals such as oribatid mites (Schneider et al., 2004; Erdmann et al., 2007; Maraun et al., 2011), springtails (Chahartaghi et al., 2005) and mesostigmatid mites (Klarner et al., 2013). Blüthgen et al. (2003) showed that stable isotopes analysis is a powerful tool for investigating trophic niche partitioning and plasticity in complex and diverse communities.

\section{Management of oil palm plantations and the 'Biodiversity Enrichment Experiment'}

Natural ecosystems are affected by human activities, including conversion into plantations and management of ecosystems (Foley et al., 2005, 2011). Until today, about $40 \%$ of the terrestrial surface has been transformed into agricultural systems (Foley et al., 2011). In part, however, these systems are not managed in a sustainable way. Rather, a considerable proportion of them is degraded; further habitat loss occurs due to construction of infrastructure and desertification processes (Bridges and Oldeman, 1999; Reynolds et al., 2007; Foley et al., 2011; Pavao-Zuckerman and Sookhdeo, 2017; Francini et al., 2018).

Intensification of land use and the associated biodiversity loss affects the structure of ecological communities and therefore the functioning of above- and belowground systems (Sodhi et al., 2004; Erdmann et al., 2007; Wilcove et al., 2013; Barnes et al., 2014; 
Edwards et al., 2014; Klarner et al., 2017). Reduced decomposer diversity may compromise decomposition processes as well as carbon and nutrient cycling (Handa et al., 2014). The large scale transformation of rainforests into monoculture plantation systems, such as oil palm and rubber, is one of the main drivers for biodiversity loss, especially in South East Asia (Fitzherbert et al., 2008; Immerzeel et al., 2014; Teuscher et al., 2016). Effects of oil palm plantation management on aboveground biodiversity and ecosystem functioning is receiving increased interest (Nurdiansyah et al., 2016; Syafiq et al., 2016; Teuscher et al., 2016; Ashton-Butt et al., 2018), however, only few studies focused on consequences for the belowground systems (Bessou et al., 2017). As soil communities are linked to the diversity and abundance of plant communities (Eisenhauer et al., 2011; Thakur and Eisenhauer, 2015), conversion of rainforest into monoculture plantations is likely to strongly affect belowground biodiversity. Therefore, to protect biodiversity of tropical regions it is important to integrate the belowground system and to consider the management of plantation systems (Koh et al., 2009; Foster et al., 2011; Luskin and Potts, 2011; Teuscher et al., 2015, 2016). Oil palm plantations may harbor a diverse understory (Foster et al., 2011), however, understory plants often compete with oil palms and therefore commonly are weeded (Tohiran et al., 2017). Removal of understory plants in oil palm plantations may be done by hand, but more commonly by the use of herbicides. However, the extensive use of herbicides may pollute water and thus provides a threat to the already endangered ecosystems (Schiesari and Grillitsch, 2011; Comte et al., 2012). In fact, the use of pesticides in agricultural land-use systems has been linked to the decline in biodiversity (Geiger et al., 2010; Beketov et al., 2013). A number of studies showed that the reduction in herbicide use and the associated increase in the coverage of understory vegetation in oil palm plantations may beneficially affect aboveground invertebrates, but 
also the decomposer system (Chung et al., 2000; Ashraf et al., 2018; Ashton-Butt et al., 2018; Spear et al., 2018; Darras et al., 2019). 
Study site

Studies of the presented theis formed part of the interdisciplinary project "Ecological and socioeconomic functions of tropical lowland rainforest transformation sytems (Sumatra, Indonesia) (Drescher et al., 2016) (Fig. 1).

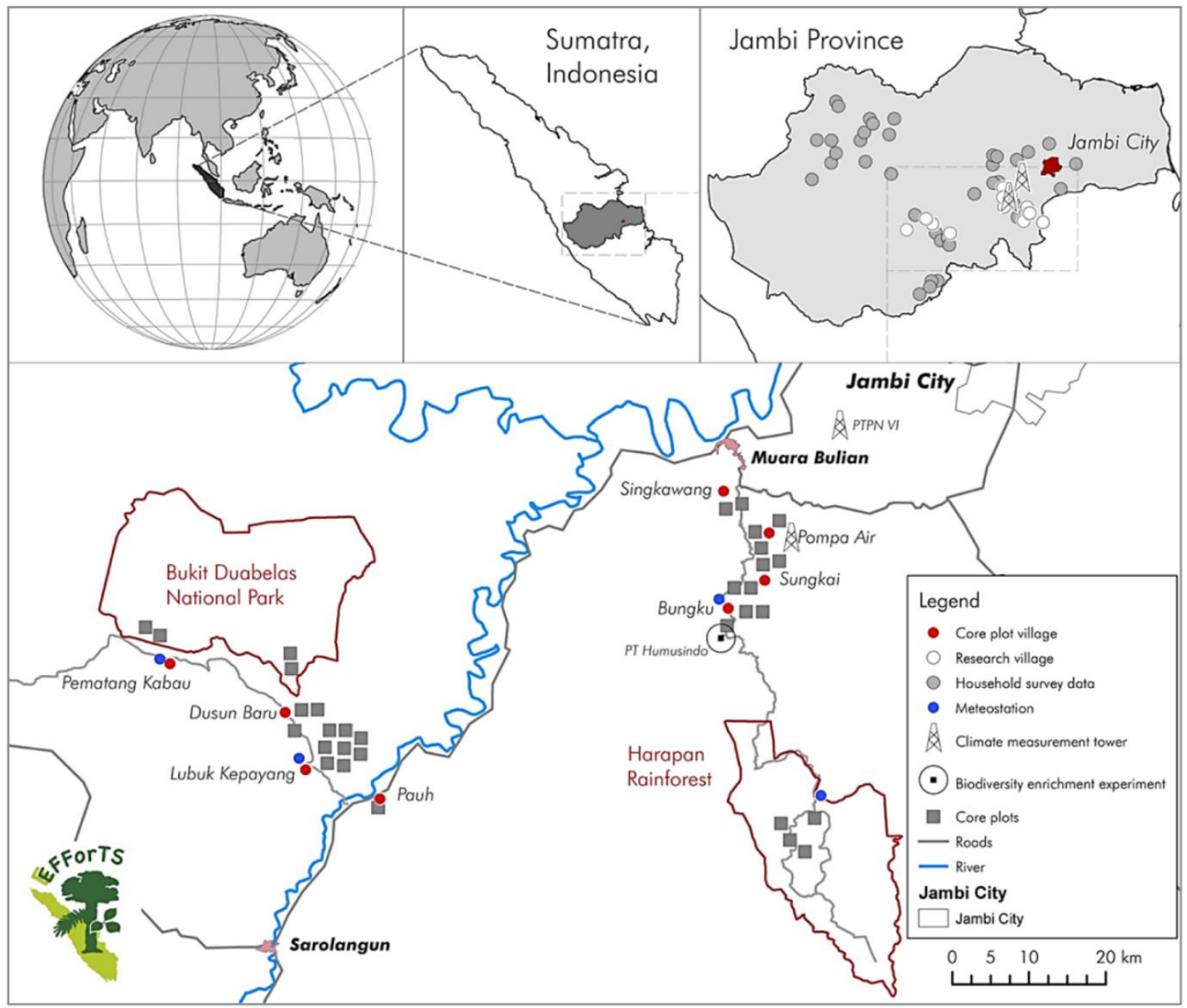

Figure 1. Location of study sites of EFForTS in Sumatra and the Jambi Province (Drescher et al., 2016), core plots are located in the two landscapes near Bukit Duabelas National Park and Harapan Rainforest. 
Two (Chapters $\mathbf{2}$ and $\mathbf{3}$ ) of the three studies reported were conducted at the EFForTS core plots established 2012 in two landscapes, Bukit Duabelas ( $\left.2^{\circ} 0^{\prime} 57^{\prime \prime} \mathrm{S}, 120^{\circ} 45^{\prime} 12^{\prime \prime} \mathrm{E}\right)$ and Harapan $\left(1^{\circ} 55^{\prime} 40^{\prime \prime} \mathrm{S}, 103^{\circ} 15^{\prime} 33^{\prime \prime} \mathrm{E}\right)$. The dominant soil type at both landscapes is Acrisol. At Bukit Duabelas soils with a clay texture predominate whereas Harapan soils are characterized by a sandy loam texture. In total, 32 core plots were established, four plots in each of four different land-use systems: lowland rainforest, jungle rubber, rubber and oil palm monoculture plantations. Rainforest plots represented "primary degraded forest" (classified by Margono et al., 2014), with signs of selective logging as well as extraction of non-timber products. Jungle rubber, represented smallholder rubber agroforest systems comprising previously logged rainforest enriched with rubber trees (Hevea brasiliensis). Both, rubber as well as oil palm plots were situated within smallholder monoculture plantations, varying between 7 to 16 years (rubber) and 8 to 15 years (oil palm) in 2012 (Drescher et al., 2016). Each plot was $50 \times 50 \mathrm{~m}$ and contained $5 \times 5 \mathrm{~m}$ subplots at random positions within the plot (Drescher et al., 2016). The third study (Chapter 4) formed part of the "Biodiversity Enrichment Experiment" established in 2013 in the framework of EFForTS in the oil palm plantation of PT Humusindo Makmur Sejata $\left(01.95^{\circ} \mathrm{S}\right.$ and $103.25^{\circ}$ E, $47 \pm 11 \mathrm{~m}$ a.s.l.) (Teuscher et al., 2016) (Fig. 2). The experiment was located in the Harapan landscape and the dominant soil type is loamy Acrisol (Allen et al., 2015). In 2016, the average age of planted oil palms was between 6 and 12 years. Management of the plantation contained fertilizer application, regular manual weeding of understory plants as well as removal of epiphytes. Herbicides were only applied if the manual weeding could not conducted due to lack of available workers (Teuscher et al., 2016). 


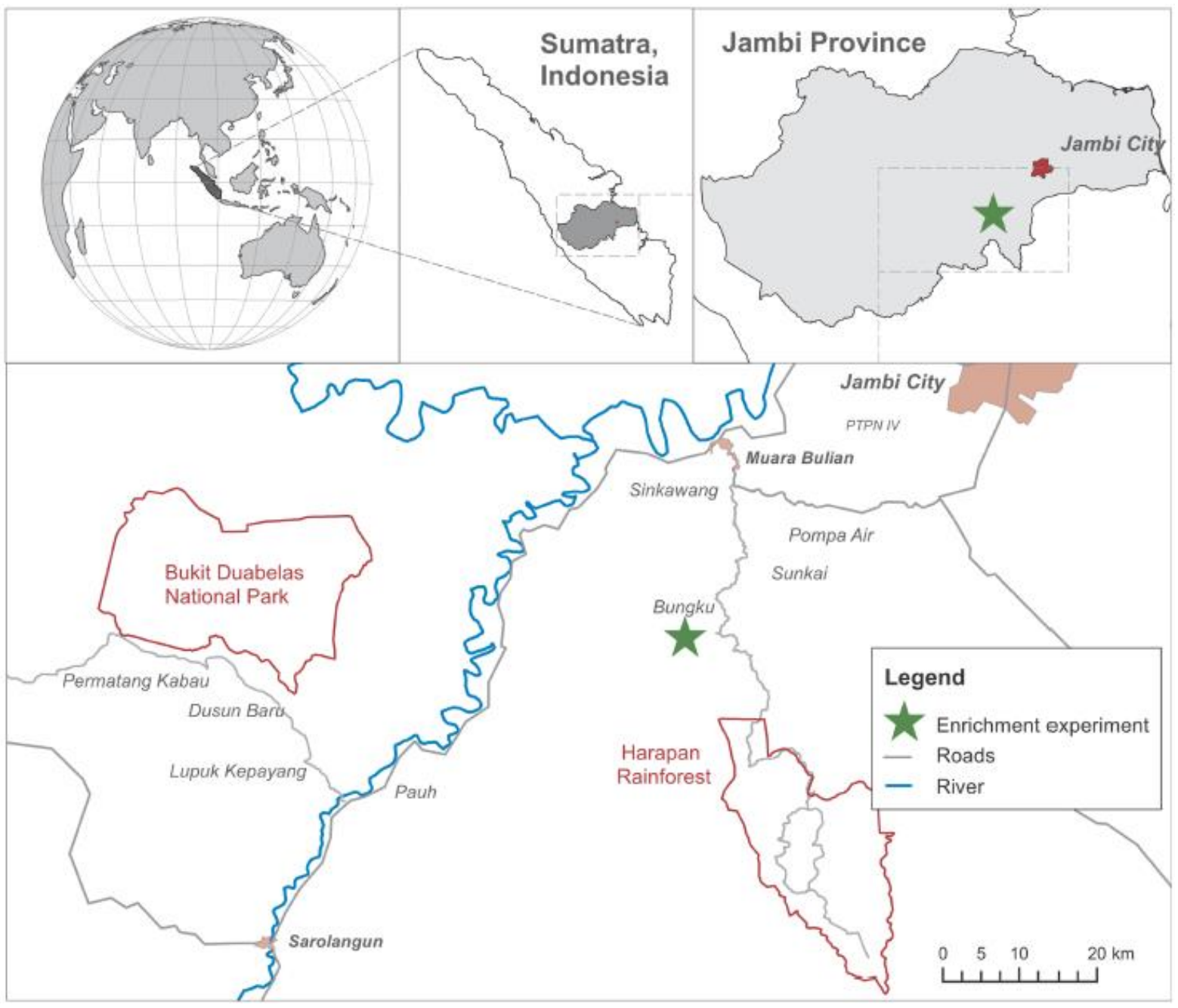

Figure 2. Map of the study area of the EFForTS Project (Drescher et al., 2016, modified from Teuscher et al., 2016). The green star indicates the location of the enrichment experiment in the oil palm plantation of PT Humusindo Makmur Sejata.

Within the oil palm plantation, tree islands of varying species diversity and compositions were established (Fig. 3). 52 plots of different plot size $(5 \times 5,10 \times 10,20 \times 20$ and $40 \times 40$ $\mathrm{m})$ as well as different tree diversity levels $(0,1,2,3$ and 6 species) were established, according to the random partitions design of Bell et al. (2009). Each tree species was selected only once at each species diversity level, therefore species composition within the tree islands was random. Additionally, four plots of the same size $(10 \times 10 \mathrm{~m})$ and 
management as usual were established as control plots (ctrl) (Teuscher et al., 2016), resulting in 56 plots total. For the enrichment of the tree islands six native trees were selected, i.e. three fruit trees (Parkia speciosa, and Archidendron pauciflorum, Fabaceae; Durio zibethinus, Malvaceae), and three timber trees (Peronema canescens, Lamiaceae; Shorea leprosula, Dipterocarpaceae), and one known to produces natural latex (Dyera polyphylla, Apocynaceae). Prior to tree planting, $40 \%$ of the oil palms were removed from the experimental plots. Management of the established plots contained manual weeding in the first two years (preventing weeds to overgrow planted saplings; every three month) which was stopped after that to allow natural succession, i.e. interaction/competition with each other and oil palms. Application of fertilizers, herbicides and insecticides in the plots were stopped after tree planting. Samples for my thesis were taken in 2016 and therefore were without manual weeding. 


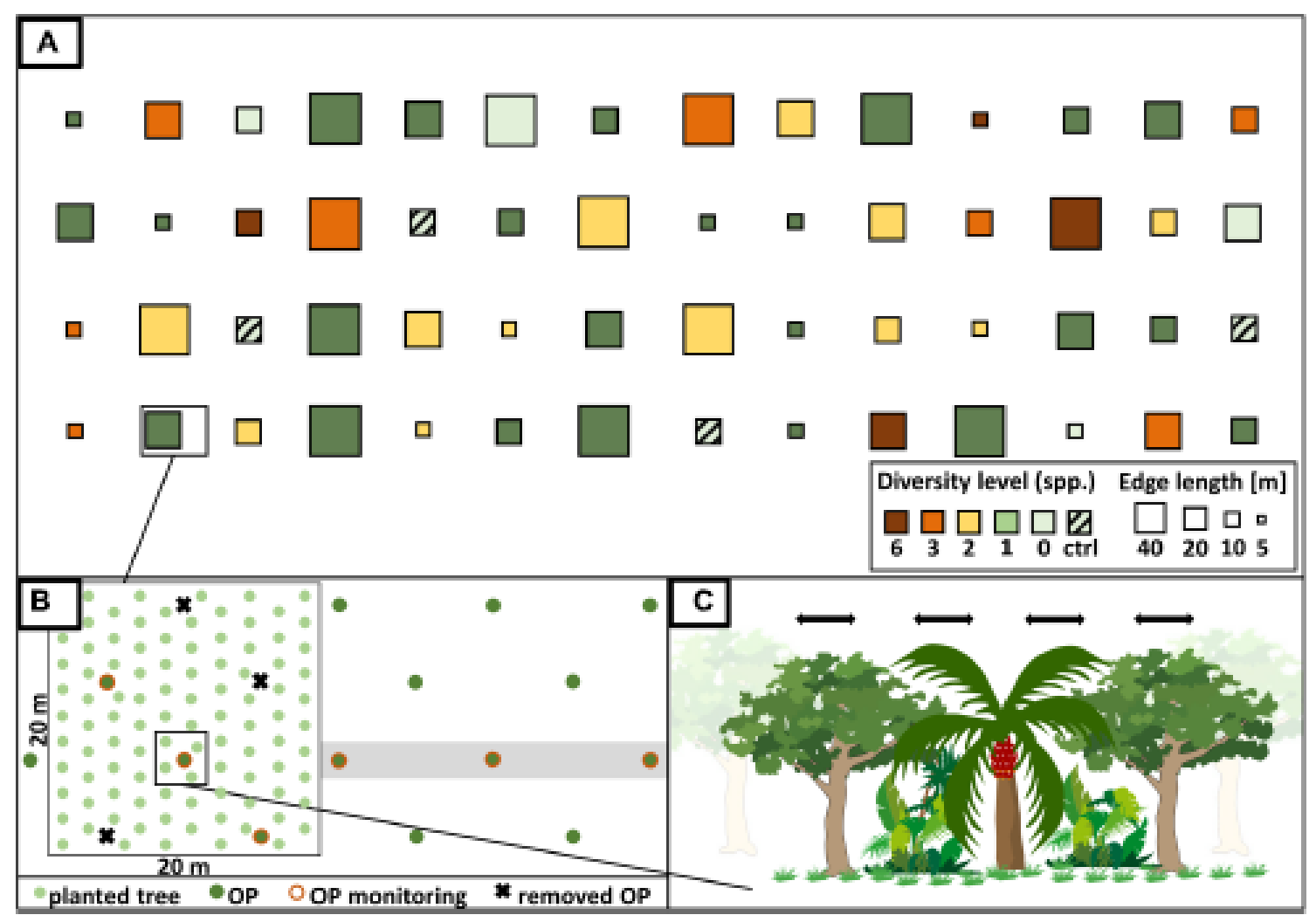

Figure 3. Study design of the biodiversity experiment (Teuscher et al., 2016). (A) Tree island with varying tree diversity levels $(0,1,2,3$ and 6 species $)$, identity and composition and plot size $(5 \times 5$, $10 \times 10,20 \times 20$ and $40 \times 40 \mathrm{~m}$ ). Four control plots without treatment and with management as usual are represented by ctrl. In total, there are 56 plots. (B) Oil palms (OP) were cut in the plots to enhance the light conditions, planted trees are in a $2 \times 2 \mathrm{~m}$ grid. (C) Planted trees interact/compete with each other and the oil palms.

\section{Objectives and chapter outline}

This thesis aims at improving the knowledge about the effects of land-use changes in South East Asia, Sumatra (Indonesia), i.e. more specifically the conversion of tropical rainforest to jungle rubber, rubber and oil palm monoculture plantations, on soil arthropod communities, especially oribatid mites, and their trophic ecology. Chapters 2 to $\mathbf{4}$ report results from field experiments with Chapter $\mathbf{2}$ investigating the shift in trophic 
niches of individual species of oribatid mites with the conversion of tropical rainforest into plantations, as indicated by stable isotopes $\left({ }^{15} \mathrm{~N},{ }^{13} \mathrm{C}\right)$. Chapter 3 investigates the shift in trophic niches of oribatid mite communities, represented by the species making up $80 \%$ of total oribatid mite individuals in the respective land-use system, as indicated by stable isotopes $\left({ }^{15} \mathrm{~N},{ }^{13} \mathrm{C}\right)$. Chapter 4 investigates the effect of the enrichment of oil palm plantations with native tree species in 'tree islands' as well as varying island size on soil invertebrate communities as part of the 'Biodiversity Enrichment Experiment'.

The main hypotheses of this thesis are as follows:

(1) Oribatid mite species cope with environmental changes in transformed ecosystems by shifting their trophic niches, with land-use system change inducing a shift in trophic levels and/or the use of basal resources indicating trophic plasticity.

(2) The trophic niche of oribatid mite communities changes with land-use system being larger in more natural systems (rainforest, jungle rubber) than in plantation systems (rubber, oil palm).

(3) The enrichment of oil palm plantations with native tree species increases the density and complexity of soil arthropod communities with the effect increasing with plot size.

The content of the three chapters can be summarized as follows:

In Chapter $\mathbf{2}$ we investigated shifts in trophic niches of six soil-living oribatid mite species (Plonaphacarus kugohi, Protoribates paracapucinus, Scheloribates praeincisus, Bischeloribates mahunkai, Rostrozetes cf. shibai, and Rostrozetes sp. 1) with the conversion of lowland secondary rainforest into plantation systems of different land use 
intensity (jungle rubber, rubber and oil palm monoculture plantation) in two regions of southwest Sumatra, Indonesia. We measured stable isotope ratios $\left({ }^{13} \mathrm{C} /{ }^{12} \mathrm{C}\right.$ and $\left.{ }^{15} \mathrm{~N} /{ }^{14} \mathrm{~N}\right)$ of single oribatid mite individuals and inspected shifts in stable isotope niches with changes in land-use systems. Significant shifts in stable isotope ratios in three of the six studied oribatid mite species (S. praeincisus, R. cf. shibai and Rostrozetes sp. 1) indicated that these species in fact shift their trophic niches with environmental changes. The trophic niche of the other three studied species (B. mahunkai, $P$. kugohi and $P$. paracapucinus) did not differ significantly between the land-use systems, but generally followed a similar trend as in the other three species. Overall, the results suggest that colonization of very different ecosystems such as rainforest and intensively managed monoculture plantations by oribatid mite species likely is related to their ability to shift their trophic niches, i.e. to trophic plasticity. Notably, the shift was due to both changes in the use of basal resources as well as trophic levels.

Chapter 3 investigated shifts in the community-level trophic niche of oribatid mites with the conversion of rainforest into rubber and oil palm plantations. We investigated $80 \%$ of oribatid mite communities occurring in lowland secondary rainforest and plantation systems of different land use intensity (jungle rubber, rubber and oil palm monoculture plantation) in two regions of southwest Sumatra, Indonesia. We measured stable isotope ratios $\left({ }^{13} \mathrm{C} /{ }^{12} \mathrm{C}\right.$ and $\left.{ }^{15} \mathrm{~N} /{ }^{14} \mathrm{~N}\right)$ of pooled individuals of oribatid mite species and inspected shifts in community-level trophic niche with changes in land-use systems. Our results confirmed that the community-level trophic niche of oribatid mites in fact is wider in rainforest than in plantation systems. Between natural and plantation systems a clear separation of the community-level trophic niche occur, indicating that with natural and 
plantation systems the community-level trophic niche of oribatid mites is totally different. As indicated by minimum and maximum of litter-calibrated isotopic signatures of oribatid mite community-level trophic niche, only oribatid mite isotopic signatures from oil palm or rubber were significantly different compared to rainforest and jungle rubber. This implies that within oil palm and rubber plantations, there are single species within oribatid mite communities which occupy trophic niches which are not present in rainforest and/or jungle rubber.

The study reported in Chapter 4 was part of the 'Biodiversity Enrichment Experiment' (see above). This experiment aimed at enhancing biodiversity and ecosystem functioning in oil palm plantations via 'tree islands' with varying diversity level $(0,1,2,3$ and 6 different tree species) and plot size $(5 \times 5,10 \times 10,20 \times 20$ and $40 \times 40 \mathrm{~m})$. We investigated the effect of 'tree islands' on macro- and mesofauna soil invertebrate taxa three years after the experiment was established. Our results demonstrated that neither the diversity level of the planted tree species nor plot size affected the abundance of soil invertebrate taxa but soil invertebrate richness varied with tree diversity. Notably, richness of soil invertebrates peaked at diversity level 2 . As soil communities respond with a delay in time to soil forming process, we expect that the observed changes will increase in time.

\section{References}

Abdullah, S.A., Nobukazu, N., 2007. Forest fragmentation and its correlation to human land use change in the state of Selangor, peninsular Malaysia. Forest Ecology and Management 241.1-3, 39-48.

Abrams, P.A., 1987. On classifying interactions between populations. Oecologia 73, 272-281.

Ahrends, A., Hollingsworth, P.M., Ziegler, A.D., Fox, J.M., Chen, H., Su, Y., Jianchu, X., 2015. Current trends of rubber plantation expansion may threaten biodiversity and livelihoods. Global Environmental Change 34, 48-58. 
Allen, K., Corre, M.D., Tjoa, A., Veldkamp, E., 2015. Soil nitrogen-cycling responses to conversion of lowland forests to oil palm and rubber plantations in Sumatra, Indonesia. PLOS ONE 10, 1-21.

Almeida, D., Almodóvar, A., Nicola, G.G., Elvira, B., Grossman, G.D., 2012. Trophic plasticity of invasive juvenile largemouth bass Micropterus salmoides in Iberian streams. Fisheries Research 113, 153-158.

Ashraf, M., Zulkifli, R., Sanusi, R., Tohiran, K.A., Terhem, R., Moslim, R., Norhisham, A.R., Ashton-Butt, A., Azhar, B., 2018. Alley-cropping system can boost arthropod biodiversity and ecosystem functions in oil palm. Agriculture, Ecosystems \& Environment 260, 19-26.

Ashton, L.A., Griffiths, H.M., Parr, C.L., Evans, T.A., Didham, R.K., Hasan, F., Teh, Y.A., Tin, H.S., Vairappan, C.S., Eggleto, P., 2019. Termites mitigate the effects of drought in tropical rainforest. Science 363, 174-177.

Ashton-Butt, A., Aryawan, A.A., Hood, A.S., Naim, M., Purnomo, D., Suhardi, S., Wahyuningsih, R., Willcock, S., Poppy, G.M., Caliman, J., Turner, E.C., Foster, W., Peh, K.S., Snaddon, J.L., 2018. Understory vegetation in oil palm plantations benefits soil biodiversity and decomposition rates, Frontier in Forest and Global Change.

Bardgett, R., 2005. The biology of soil: A community and ecosystem approach. Oxford University Press.

Barnes, A.D., Jochum, M., Mumme, S., Haneda, N.F., Farajallah, A., Widarto, T.H., Brose, U., 2014. Consequences of tropical land use for multitrophic biodiversity and ecosystem functioning. Nature Communications 5, 1-7.

Bedano, J.C., Domínguez, A., Arolfo, R., 2011. Assessment of soil biological degradation using mesofauna. Soil and Tillage Research 117, 55-60.

Behan-Pelletier, V.M., 1999. Oribatid mite biodiversity in agroecosystems: Role for bioindication. Agriculture, Ecosystems and Environment 74, 411-423.

Beketov, M. A., Kefford, B.J., Schafer, R.B., Liess, M., 2013. Pesticides reduce regional biodiversity of stream invertebrates. Proceedings of the National Academy of Sciences 110, 11039-11043.

Bell, T., Lilley, A.K., Hector, A., Schmid, B., King, L., Newman, J.A., 2009. A linear model method for biodiversity-ecosystem functioning experiments. The American Naturalist 174, 836-849.

Berg, B., McClaugherty, C., 2008. Plant Litter: Decomposition, humus formation carbon sequestration. Springer-Verlag Heidelberg.

Berg, M.P., Bengtsson, J., 2007. Temporal and spatial variability in soil food web structure. Oikos 116, 17891804.

Bessou, C., Verwilghen, A., Beaudoin-Ollivier, L., Marichal, R., Ollivier, J., Baron, V., Bonneau, X., Carron, M.-P., Snoeck, D., Naim, M., Ketuk Aryawan, A.A., Raoul, F., Giraudoux, P., Surya, E., Sihombing, E., Caliman, J.-P., 2017. Agroecological practices in oil palm plantations: Examples from the field. Ocl 24.

Beukema, H., Danielsen, F., Vincent, G., Hardiwinoto, S., Van Andel, J., 2007. Plant and bird diversity in rubber agroforests in the lowlands of Sumatra, Indonesia. Agroforestry Systems 70, 217-242. 
Birch, L.C., 1957. The meanings of competition. The American Naturalist 91, 5-18.

Blüthgen, N., Gebauer, G., Fiedler, K., 2003. Disentangling a rainforest food web using stable isotopes: Dietary diversity in a species-rich ant community. Oecologia 137, 426-435.

Boecklen, W.J., Yarnes, C.T., Cook, B.A., James, A.C., 2011. On the use of stable isotopes in trophic ecology. Annual Review of Ecology, Evolution, and Systematics 42, 411-440.

Bommarco, R., Biesmeijer, J.C., Meyer, B., Potts, S.G., Pöyry, J., Roberts, S.P.M., Steffan-Dewenter, I., Ockinger, E., 2010. Dispersal capacity and diet breadth modify the response of wild bees to habitat loss. Proceedings of the Royal Society B: Biological Sciences 277, 2075-2082.

Bonachela, J.A., Pringle, R.M., Sheffer, E., Coverdale, T.C., Guyton, J.A., Caylor, K.K., Levin, S.A., Tarnita, C.E., 2015. Termite mounds can increase the robustness of dryland ecosystems to climatic change. Science 347, 651-655.

Bowen, S.H., Allanson, B.R., 1982. Behavioral and trophic plasticity of juvenile Tilapia mossambica in utilization of the unstable littoral habitat. Environmental Biology of Fishes 7, 357-362.

Bridges, E.M., Oldeman, L.R., 1999. Global assessment of human-induced soil degradation. Arid Soil Research and Rehabilitation 13, 319-325.

Brückner, A., Schuster, R., Smit, T., Heethoff, M., 2018. Imprinted or innate food preferences in the model mite Archegozetes. Soil Organisms 90, 23-26.

Brussaard, L., Pulleman, M.M., Ouédraogo, É., Mando, A., Six, J., 2007. Soil fauna and soil function in the fabric of the food web. Pedobiologia 50, 447-462.

Carter, C., Finley, W., Fry, J., Jackson, D., Willis, L., 2007. Palm oil markets and future supply. European Journal of Lipid Science and Technology 109, 307-314.

Casey, M.M., Post, D.M., 2011. The problem of isotopic baseline: Reconstructing the diet and trophic position of fossil animals. Earth-Science Reviews 106, 131-148.

Chahartaghi, M., Langel, R., Scheu, S., Ruess, L., 2005. Feeding guilds in Collembola based on nitrogen stable isotope ratios. Soil Biology and Biochemistry 37, 1718-1725.

Chase, J.M., Leibold, M.A., 2003. Ecological niches: Linking classical and contemporary approaches. University of Chicago Press.

Chung, A.Y.C., Eggleton, P., Speight, M.R., Hammond, P.M., Chey, V.K., 2000. The diversity of beetle assemblages in different habitat types in Sabah, Malaysia. Bulletin of Entomological Research 90, 475496.

Clay, J., 2013. World agriculture and the environment: A commodity-by-commodity guide to impacts and practices. Island Press. 
Comte, I., Colin, F., Whalen, J.K., Grünberger, O., Caliman, J.P., 2012. Agricultural practices in oil palm plantations and their impact on hydrological changes, nutrient fluxes and water quality in Indonesia. A review., 1st ed, Advances in Agronomy. Elsevier Inc.

Corley, R., Hereward, V., Tinker, P.B., 2008. The oil palm. John Wiley \& Sons.

Coûteaux, M.M., Bottner, P., Berg, B., 1995. Litter decomposition, climate and liter quality. Trends in Ecology \& Evolution 12.2, 63-66.

Curran, L.M., Trigg, S.N., Mcdonald, A.K., Astiani, D., Hardiono, Y.M., Siregar, P., Caniago, I., Kasischke, E., 2004. Lowland forest loss in protected areas. Science 303, 1000-1003.

Dammhahn, M., Randriamoria, T.M., Goodman, S.M., 2017. Broad and flexible stable isotope niches in invasive non-native Rattus spp. in anthropogenic and natural habitats of central eastern Madagascar. BMC Ecology 17, 1-13.

Danielsen, F., Beukema, H., Burgess, N.D., Parish, F., Brühl, C.A., Donald, P.F., Murdiyarso, D., Phalan, B., Reijnders, L., Struebig, M., Fitzherbert, E.B., 2009. Biofuel plantations on forested lands: Double jeopardy for biodiversity and climate. Conservation Biology 23, 348-358.

Darras, K., Corre, M.D., Formaglio, G., Tjoa, A., Potapov, A., Sibhatu, K.T., Grass, I., Tscharntke, T., Rubiano, A.A., Buchori, D., Drescher, J., Fardiansah, R., Hölscher, D., Irawan, B., Kneib, T., Krashevska, V., Krause, A., Kreft, H., Li, K., Polle, A., Ryadin, A.R., Rembold, K., Scheu, S., 2019. Reducing fertilizer and avoiding herbicides in oil palm plantations - Ecological and economic valuation. Frontiers in Forests and Global Change 2, 65.

David, J.F., 2014. The role of litter-feeding macroarthropods in decomposition processes: A reappraisal of common views. Soil Biology and Biochemistry 76, 109-118.

De Ruiter, P.C., Van Veen, J.A., Moore, J.C., Brussaard, L., Hunt, H.W., 1993. Calculation of nitrogen mineralization in soil food webs. Plant and Soil 157, 263-273.

De Vries, F.T., Thebault, E., Liiri, M., Birkhofer, K., Tsiafouli, M. a., Bjornlund, L., Bracht Jorgensen, H., Brady, M. V., Christensen, S., de Ruiter, P.C., d'Hertefeldt, T., Frouz, J., Hedlund, K., Hemerik, L., Hol, W.H.G., Hotes, S., Mortimer, S.R., Setala, H., Sgardelis, S.P., Uteseny, K., van der Putten, W.H., Wolters, V., Bardgett, R.D., 2013. Soil food web properties explain ecosystem services across European land use systems. Proceedings of the National Academy of Sciences 110, 14296-14301.

Deagle, B.E., Kirkwood, R., Jarman, S.N., 2009. Analysis of Australian fur seal diet by pyrosequencing prey DNA in faeces. Molecular Ecology 18, 2022-2038.

DeFries, R., Foley, J., Asner, G., 2004. Balancing human needs and ecosystem function. Front Ecol Environ 2, 249-257.

DeNiro, M.J., Epstein, S., 1978. Influence of diet on the distribution of nitrogen isotopes in animals. Geochimica et Cosmochimica Acta 45, 341-351.

Dennis, R. a., Mayer, J., Applegate, G., Chokkalingam, U., Colfer, C.J.P., Kurniawan, I., Lachowski, H., Maus, P., Permana, R.P., Ruchiat, Y., Stolle, F., Suyanto, Tomich, T.P., 2005. Fire, people and pixels: Linking 
social science and remote sensing to understand underlying causes and impacts of fires in Indonesia. Human Ecology 33, 465-504.

Di Lascio, A., Rossi, L., Pasquale, C., Calizza, E., Rossi, D., Costantini, M.L., Achtziger, R., 2013. Stable isotope variation in macroinvertebrates indicates anthropogenic disturbance along an urban stretch of the river Tiber (Rome, Italy). Ecological Indicators 28, 107-114.

Dirzo, R., Raven, P.H., 2003. Global state of biodiversity and loss. Annual Review of Environment and Resources 28, 137-167.

Donald, P.F., 2004. Biodiversity impacts of some agricultural. Issues Int. Conserv. 18, 17-37.

Drescher, J., Rembold, K., Allen, K., Beckscha, P., Buchori, D., Clough, Y., Faust, H., Fauzi, A.M., Gunawan, D., Hertel, D., Irawan, B., Jaya, I.N.S., Klarner, B., Kleinn, C., Knohl, A., Kotowska, M.M., Krashevska, V., Krishna, V., Leuschner, C., Lorenz, W., Meijide, A., Melati, D., Steinebach, S., Tjoa, A., Tscharntke, T., Wick, B., Wiegand, K., Kreft, H., Scheu, S., 2016. Ecological and socio-economic functions across tropical land use systems after rainforest conversion. Philosophical Transactions of the Royal Society of London. Series B, Biological Sciences 231, 1-7.

Drymon, J.M., Powers, S.P., Carmichael, R.H., 2012. Trophic plasticity in the Atlantic sharpnose shark (Rhizoprionodon terraenovae) from the north central Gulf of Mexico. Environmental Biology of Fishes 95, 21-35.

Ducarme, X., André, H.M., Wauthy, G., Lebrun, P., 2004. Are there real endogeic species in temperate forest mites? Pedobiologia 48, 139-147.

Edwards, F.A., Edwards, D.P., Larsen, T.H., Hsu, W.W., Benedick, S., Chung, a., Vun Khen, C., Wilcove, D.S., Hamer, K.C., 2014. Does logging and forest conversion to oil palm agriculture alter functional diversity in a biodiversity hotspot? Animal Conservation 17, 163-173.

Ehleringer, J.R., Rundel, P.W., Nagy, K. a., 1986. Stable isotopes in physiological ecology and food web research. Trends in Ecology and Evolution 1, 42-45.

Eisenhauer, N., Milcu, A., Sabais, A.C.W., Bessler, H., Brenner, J., Engels, C., Klarner, B., Maraun, M., Partsch, S., Roscher, C., Schonert, F., Temperton, V.M., Thomisch, K., Weigelt, A., Weisser, W.W., Scheu, S., 2011. Plant diversity surpasses plant functional groups and plant productivity as driver of soil biota in the long term. PLOS ONE 6, 15-18.

Elton, C.S., 1927. Animal ecology: London. Sidgwick and Jackson, Ltd.

Erdmann, G., Otte, V., Langel, R., Scheu, S., Maraun, M., 2007. The trophic structure of bark-living oribatid mite communities analysed with stable isotopes $\left({ }^{15} \mathrm{~N},{ }^{13} \mathrm{C}\right)$ indicates strong niche differentiation. Experimental and Applied Acarology 41, 1-10.

Ettema, C.H., Wardle, D.A., 2002. Spatial soil ecology. Trends in Ecology \& Evolution 17.4, 177-183.

European Comission, 2006. An EU Strategy for biofuels, impact assessment. 18. 
Filser, J., Faber, J.H., Tiunov, A. V., Brussaard, L., Frouz, J., De Deyn, G., Uvarov, A. V., Berg, M.P., Lavelle, P., Loreau, M., Wall, D.H., Querner, P., Eijsackers, H., Jiménez, J.J., 2016. Soil fauna: Key to new carbon models. Soil 2, 565-582.

Finlay-Doney, M., Walter, G.H., 2012. The conceptual and practical implications of interpreting diet breadth mechanistically in generalist predatory insects. Biological Journal of the Linnean Society 107, 737-763.

Fitzherbert, E.B., Struebig, M.J., Morel, A., Danielsen, F., Brühl, C.A., Donald, P.F., Phalan, B., 2008. How will oil palm expansion affect biodiversity? Trends in Ecology and Evolution 23, 538-545.

Foley, J. a., Ramankutty, N., Brauman, K.A., Cassidy, E.S., Gerber, J.S., Johnston, M., Mueller, N.D., O'Connell, C., Ray, D.K., West, P.C., Balzer, C., Bennett, E.M., Carpenter, S.R., Hill, J., Monfreda, C., Polasky, S., Rockström, J., Sheehan, J., Siebert, S., Tilman, D., Zaks, D.P.M., 2011. Solutions for a cultivated planet. Nature 478, 337-342.

Foley, J.A., Defries, R., Asner, G.P., Barford, C., Bonan, G., Carpenter, S.R., Chapin, S.F., Coe, M.T., Daily, G.C., Gibbs, H.K., Helkowski, J.H., Holloway, T., Howard, E.A., Kucharik, C.J., Monfreda, C., Patz, J.A., Prentice, C.I., Ramankutty, N., Snyder, P.K., 2005. Global consequences of land use. Science 309, 570574.

Folgarait, P., 1998. Ant biodiversity to ecosystem functioning: A review. Biodiversity And Conservation 7, 1121-1244.

Foster, W.A., Snaddon, J.L., Turner, E.C., Fayle, T.M., Cockerill, T.D., Farnon Ellwood, M.D., Broad, G.R., Chung, A.Y.C., Eggleton, P., Khen, C.V., Yusah, K.M., 2011. Establishing the evidence base for maintaining biodiversity and ecosystem function in the oil palm landscapes of South East Asia. Philosophical Transactions of the Royal Society B: Biological Sciences 366, 3277-3291.

Francini, G., Hui, N., Jumpponen, A., Kotze, D.J., Romantschuk, M., Allen, J.A., Setälä, H., 2018. Soil biota in boreal urban greenspace: Responses to plant type and age. Soil Biology and Biochemistry 118, 145155.

Fry, B., 2006. Stable isotope ecology. New York: Springer.

Gan, H., Zak, D.R., Hunter, M.D., 2014. Trophic stability of soil oribatid mites in the face of environmental change. Soil Biology and Biochemistry 68, 71-77.

Gariepy, T.D., Kuhlmann, U., Gillott, C., Erlandson, M., 2007. Parasitoids, predators and PCR: The use of diagnostic molecular markers in biological control of Arthropods. Journal of Applied Entomology 131, 225-240.

Geiger, F., Bengtsson, J., Berendse, F., Weisser, W.W., Emmerson, M., Morales, M.B., Ceryngier, P., Liira, J., Tscharntke, T., Winqvist, C., Eggers, S., Bommarco, R., Pärt, T., Bretagnolle, V., Plantegenest, M., Clement, L.W., Dennis, C., Palmer, C., Onate, J.J., Guerrero, I., Hawro, V., Aavik, T., Thies, C., Flohre, A., Hänke, S., Fischer, C., Goedhart, P.W., Inchausti, P., 2010. Persistent negative effects of pesticides on biodiversity and biological control potential on European farmland. Basic and Applied Ecology 11, 97-105. 
Gibbs, H.K., Ruesch, A.S., Achard, F., Clayton, M.K., Holmgren, P., Ramankutty, N., Foley, J.A., 2010. Tropical forests were the primary sources of new agricultural land in the 1980s and 1990s. Proceedings of the National Academy of Sciences of the USA 107, 16732-16737.

Godfray, H.C.J., Beddington, J.R., Crute, I.R., Haddad, L., Lawrence, D., Muir, J.F., Pretty, J., Robinson, S., Thomas, S.M., Toulmin, C., 2010. Food Security: The challenge of feeding 9 billion people 327, 812818.

Green, R.E., Cornell, S.J., Scharlemann, J.P.W., Balmford, A., 2005. Farming and the fate of wild nature. Science 307, 550-555.

Günther, B., Rall, B.C., Ferlian, O., Scheu, S., Eitzinger, B., 2014. Variations in prey consumption of centipede predators in forest soils as indicated by molecular gut content analysis. Oikos 123, 1192-1198.

Handa, I.T., Aerts, R., Berendse, F., Berg, M.P., Bruder, A., Butenschoen, O., Chauvet, E., Gessner, M.O., Jabiol, J., Makkonen, M., McKie, B.G., Malmqvist, B., Peeters, E.T.H.M., Scheu, S., Schmid, B., Van Ruijven, J., Vos, V.C.A., Hättenschwiler, S., 2014. Consequences of biodiversity loss for litter decomposition across biomes. Nature 509, 218-221.

Hansen, A.G., Gardner, J.R., Connelly, K.A., Polacek, M., Beauchamp, D.A., 2018. Trophic compression of lake food webs under hydrologic disturbance. Ecosphere 9.

Hasegawa, M., Ito, M.T., Yoshida, T., Seino, T., Chung, A.Y., Kitayama, K., 2014. The effects of reducedimpact logging practices on soil animal communities in the Deramakot Forest Reserve in Borneo. Applied Soil Ecology 83, 13-21.

Hutchinson, G.E., 1978. An introduction to population ecology. Yale University Press.

Hutchinson, G.E., 1959. Homage to Santa Rosalia or why are there so many kinds of animals. American Natrualist 93, 145-159.

Illig, J., Langel, R., Norton, R.A., Scheu, S., Maraun, M., 2005. Where are the decomposers? Uncovering the soil food web of a tropical montane rain forest in southern Ecuador using stable isotopes $\left({ }^{15} \mathrm{~N}\right)$. Journal of Tropical Ecology 21, 589-593.

Immerzeel, D.J., Verweij, P.A., Van der Hilst, F., Faaij, A.P.C., 2014. Biodiversity impacts of bioenergy crop production: A state-of-the-art review. GCB Bioenergy 6, 183-209.

Jardine, T.D., Kidd, K.A., Fisk, A.T., 2006. Applications, considerations, and sources of uncertainty when using stable isotope analysis in ecotoxicology. Environmental Science and Technology 40, 7501-7511.

Jones, G., 2013. The population of Southeast Asia.

Klarner, B., Maraun, M., Scheu, S., 2013. Trophic diversity and niche partitioning in a species rich predator guild - Natural variations in stable isotope ratios $\left({ }^{13} \mathrm{C} /{ }^{12} \mathrm{C},{ }^{15} \mathrm{~N} /{ }^{14} \mathrm{~N}\right.$ ) of mesostigmatid mites (Acari, Mesostigmata) from Central European beech. Soil Biology and Biochemistry 57, 327-333. 
Klarner, B., Winkelmann, H., Krashevska, V., Maraun, M., Widyastuti, R., Scheu, S., 2017. Trophic niches, diversity and community composition of invertebrate top predators (Chilopoda) as affected by conversion of tropical lowland rainforest in Sumatra (Indonesia). PLOS ONE 1-17.

Koh, L.P., Levang, P., Ghazoul, J., Bhagwat, S.A., Willis, K.J., 2009. Designer landscapes for sustainable biofuels. Trends in Ecology \& Evolution 24, 431-438.

Koh, L.P., Wilcove, D.S., 2008. Is oil palm agriculture really destroying tropical biodiversity? Conservation Letters 1, 60-64.

Koh, L.P., Wilcove, D.S., 2007. Cashing in palm oil for conservation. Nature 448, 993-994.

Korotkevich, A.Y., Potapov, A.M., Tiunov, A.V., Kuznetsova, N.A., 2018. Collapse of trophic-niche structure in belowground communities under anthropogenic disturbance. Ecosphere 9.

Kraft, N.J.B., Adler, P.B., Godoy, O., James, E.C., Fuller, S., Levine, J.M., 2015. Community assembly, coexistence and the environmental filtering metaphor. Functional Ecology 29, 592-599.

Krantz, G.W., Behan-Pelletier, V.M., Cook, D.R., Harvey, M.S., Keirans, J.E., Lindquist, E.E., Norton, R.A., OConner, B.M., Smith, I.M., Walter, D.E., 2009. A manual of Acarology, Third Edit. ed. Texas Tech University Press.

Krause, A., Sandmann, D., Bluhm, S.L., Ermilov, S., Widyastuti, R., Haneda, N.F., Scheu, S., Maraun, M., 2019. Shift in trophic niches of soil microarthropods with conversion of tropical rainforest into plantations as indicted by stable isotopes $\left({ }^{15} \mathrm{~N},{ }^{13} \mathrm{C}\right)$. PLOS ONE 14.10. e0224520.

Krebs, C.J., 1994. Ecology: The experimental analysis of distribution and abundance, 6th ed. New York: Harper Collins College Publishers.

Kreipe, V., Corral-Hernández, E., Scheu, S., Schaefer, I., Maraun, M., 2015. Phylogeny and species delineation in European species of the genus Steganacarus (Acari, Oribatida) using mitochondrial and nuclear markers. Experimental and Applied Acarology 173-186.

Lal, R., 1988. Effects of macrofauna on soil properties in tropical ecosystems. Agriculture, Ecosystems and Environment 24, 101-116.

Lambin, E.F., Meyfroidt, P., 2011. Global land use change, economic globalization, and the looming land scarcity. Proceedings of the National Academy of Sciences of the United States of America 108, 34653472.

Langel, R., Dyckmans, J., 2014. Combined ${ }^{13} \mathrm{C}$ and ${ }^{15} \mathrm{~N}$ isotope analysis on small samples using a nearconventional elemental analyzer/isotope ratio mass spectrometer setup. Rapid Communications in Mass Spectrometry 28, 1019-1022.

Laumonier, Y., Uryu, Y., Stüwe, M., Budiman, A., Setiabudi, B., Hadian, O., 2010. Eco-floristic sectors and deforestation threats in Sumatra: Identifying new conservation area network priorities for ecosystembased land use planning. Biodiversity and Conservation 19, 1153-1174. 
Leibold, M.A., 1995. The niche concept revisited: Mechanistic models and community context. Ecology 76, 1371-1382.

Lotka, A.J., 1925. Elements of physical biology. New York (reprint): Dover Publications.

Luskin, M.S., Potts, M.D., 2011. Microclimate and habitat heterogeneity through the oil palm lifecycle. Basic and Applied Ecology 12, 540-551.

Macarthur, R., Levins, R., Naturalist, T.A., Oct, N.S., Macarthur, R., Levins, R., 1967. The limiting similarity hypothesis. The American Naturalist 101, 377-385.

Maraun, M., Erdmann, G., Fischer, B.M., Pollierer, M.M., Norton, R.A., Schneider, K., Scheu, S., 2011. Stable isotopes revisited: Their use and limits for oribatid mite trophic ecology. Soil Biology and Biochemistry 43, 877-882.

Maraun, M., Heethoff, M., Schneider, K., Scheu, S., Weigmann, G., Cianciolo, J., Thomas, R.H., Norton, R.A., 2004. Molecular phylogeny of oribatid mites (Oribatida, Acari): Evidence for multiple radiations of parthenogenetic lineages. Experimental and Applied Acarology 33, 183-201.

Maraun, M., Schatz, H., Scheu, S., 2007. Awesome or ordinary? Global diversity patterns of oribatid mites. Ecography 30, 209-216.

Maraun, M., Scheu, S., 2000. The structure of oribatid mite communities (Acari, Oribatida): Patterns, mechanisms and implications for future research. Source: Ecography 23, 374-383.

Margono, B.A., Potapov, P.V., Turubanova, S., Stolle, F., Hansen, M.C., 2014. Primary forest cover loss in Indonesia over 2000-2012. Nature Climate Change 4, 730-735.

Martin, A., Balesdent, J., Mariotti, A., 1992. Earthworm diet related to soil organic matter dynamics through ${ }^{13} \mathrm{C}$ measurments. Oecologia 91, 23-29.

Martínez Del Rio, C., Wolf, N., Carleton, S.A., Gannes, L.Z., 2009. Isotopic ecology ten years after a call for more laboratory experiments. Biological Reviews 84, 91-111.

McNaughton, S.J., Oesterheld, M., Frank, D.A., Williams, K.J., 1989. Ecosystem-level patterns of primary productivity and herbivory in terrestrial habitats. Nature $341,142-144$.

Meijide, A., Badu, C.S., Moyano, F., Tiralla, N., Gunawan, D., Knohl, A., 2018. Impact of forest conversion to oil palm and rubber plantations on microclimate and the role of the 2015 ENSO event. Agricultural and Forest Meteorology 252, 208-2019.

Miettinen, J., Shi, C., Liew, S.C., 2011. Deforestation rates in insular Southeast Asia between 2000 and 2010. Global Change Biology 17, 2261-2270.

Migge-Kleian, S., McLean, M.A., Maerz, J.C., Heneghan, L., 2006. The influence of invasive earthworms on indigenous fauna in ecosystems previously uninhabited by earthworms. Biological Invasions Belowground: Earthworms as Invasive Species 8, 75-85. 
Migge-Kleian, S., Woltmann, L., Anas, I., Schulz, W., Steingrebe, A., Schaefer, M., 2007. Impact of forest disturbance and land use change on soil and litter arthropod assemblages in tropical rainforest margins, in: Stability of Tropical Rainforest Margins. Springer Berlin Heidelberg, pp. 147-163.

Minagawa, M., Wada, E., 1984. Stepwise enrichment of ${ }^{15} \mathrm{~N}$ along food chains: Further evidence and the relation between $\delta^{15} \mathrm{~N}$ and animal age. Geochimica et Cosmochimica Acta 48, 1135-1140.

Moore, J.C., de Ruiter, P.C., 2012. Energetic food webs: An analysis of real and model ecosystems, Ecology Letters.

Newbold, T., Hudson, L.N., Hill, S.L.L., Contu, S., Lysenko, I., Senior, R. a., Börger, L., Bennett, D.J., Choimes, A., Collen, B., Day, J., De Palma, A., Díaz, S., Echeverria-Londoño, S., Edgar, M.J., Feldman, A., Garon, M., Harrison, M.L.K., Alhusseini, T., Ingram, D.J., Itescu, Y., Kattge, J., Kemp, V., Kirkpatrick, L., Kleyer, M., Correia, D.L.P., Martin, C.D., Meiri, S., Novosolov, M., Pan, Y., Phillips, H.R.P., Purves, D.W., Robinson, A., Simpson, J., Tuck, S.L., Weiher, E., White, H.J., Ewers, R.M., MacE, G.M., Scharlemann, J.P.W., Purvis, A., 2015. Global effects of land use on local terrestrial biodiversity. Nature 520, 45-50.

Nielsen, U.N., 2019. Soil fauna assamblages global to local scales. Cambridge University Press.

Nielsen, U.N., Ayres, E., Wall, D.H., Bardgett, R.D., 2011. Soil biodiversity and carbon cycling: A review and synthesis of studies examining diversity-function relationships. European Journal of Soil Science 62, 105-116.

Nielsen, U.N., Osler, G.H., van der Wal, R., Campbell, C.D., Burslem, D.F., 2008. Soil pore volume and the abundance of soil mites in two contrasting habitats. Soil Biology and Biochemistry 40, 1538-1541.

Nielsen, U.N., Wall, D.H., Six, J., 2015. Soil biodiversity and the environment. Annual Review of Environment and Resources 40, 63-90.

Nurdiansyah, F., Denmead, L.H., Clough, Y., Wiegand, K., Tscharntke, T., 2016. Biological control in Indonesian oil palm potentially enhanced by landscape context. Agriculture, Ecosystems \& Environment 232, 141-149.

Parr, C.L., Eggleton, P., Davies, A.B., Evans, T.A., Holdsworth, S., 2016. Suppression of savanna ants alters invertebrate composition and influences key ecosystem processes. Ecology 97, 1611-1617.

Pavao-Zuckerman, M.A., Sookhdeo, C., 2017. Nematode community response to green infrastructure design in a semiarid city. Journal of Environmental Quality 46, 687-694.

Peñuelas, J., Sardans, J., Rivas-ubach, A., Janssens, I.A., 2012. The human-induced imbalance between C, N and $\mathrm{P}$ in Earth's life system. Global Change Biology 18, 3-6.

Petersen, H., Luxton, M., 1982. A comparative analysis of soil fauna populations and their role in decomposition processes. Oikos 288-388.

Pollierer, M.M., Langel, R., Scheu, S., Maraun, M., 2009. Compartmentalization of the soil animal food web as indicated by dual analysis of stable isotope ratios $\left({ }^{15} \mathrm{~N} /{ }^{14} \mathrm{~N}\right.$ and $\left.{ }^{13} \mathrm{C} /{ }^{12} \mathrm{C}\right)$. Soil Biology and Biochemistry 41, 1221-1226. 
Ponsard, S., Arditi, R., 2000. What can stable isotopes $\left(\delta^{15} \mathrm{~N}\right.$ and $\left.\delta^{13} \mathrm{C}\right)$ tell about the food web of soil macroinvertebrates? Ecology 81, 852-864.

Post, D.M., 2002. Using stable isotopes to estimate trophic position: Models, methos, and assumptions. Ecology 83, 703-718.

Potapov, A.M., Tiunov, A.V., Scheu, S., 2019. Uncovering trophic positions and food resources of soil animlas using bulk natural stable isotope composition. Biological Reviews 94, 37-59.

Reynolds, J.F., Smith, D.M.S., Mortimore, M., Herrick, J.E., Downing, T.E., Batterbury, S.P.J., Maestre, F.T., Huber-Sannwald, E., Turner, B.L., Dowlatabadi, H., Walker, B., Ayarza, M., Reynolds, J.F., Leemans, R., Lambin, E.F., Lynam, T., Jiang, H., Fernandez, R.J., 2007. Global desertification: Building a science for dryland development. Science 316, 847-851.

Riera, P., 2010. Trophic plasticity of the gastropod Hydrobia ulvae within an intertidal bay (Roscoff, France): A stable isotope evidence. Journal of Sea Research 63, 78-83.

Root, R.B., 1967. The niche exploitation pattern of the blue-gray gnatcatcher. Ecological Monographs 37, 317-350.

Ruess, L., Chamberlain, P.M., 2010. The fat that matters: Soil food web analysis using fatty acids and their carbon stable isotope signature. Soil Biology and Biochemistry 42, 1898-1919.

Scheu, S., 2002. The soil food web: Structure and perspectives. European Journal of Soil Biology 38, 11-20.

Scheu, S., Falca, M., 2000. The soil food web of two beech forests (Fagus sylvatica) of contrasting humus type: Stable isotope analysis of a macro- and a mesofauna-dominated community. Oecologia 123, 285-296.

Scheu, S., Illig, J., Eissfeller, V., Krashevska, V., Sandmann, D., Maraun, M., 2008. The soil fauna of a tropical mountain rainforest in southern Ecuador: Structure and functioning, The tropical mountain forest. Patterns and Processes in a Biodiversity Hotspots. Biodiversity and Ecology Series 2. Göttingen, Universitätsverlag.

Schiesari, L., Grillitsch, B., 2011. Pesticides meet megadiversity in the expansion of biofuel crops. Frontiers in Ecology and the Environment 9, 215-221.

Schneider, K., Migge, S., Norton, R.A., Scheu, S., Langel, R., Reineking, A., Maraun, M., 2004. Trophic niche differentiation in soil microarthropods (Oribatida, Acari): Evidence from stable isotope ratios $\left({ }^{15} \mathrm{~N} /{ }^{14} \mathrm{~N}\right)$. Soil Biology and Biochemistry 36, 1769-1774.

Sodhi, N.S., Koh, L.P., Brook, B.W., Ng, P.K., 2004. Southeast Asian biodiversity: An impending disaster. Trends in Ecology and Evolution 19, 654-660.

Sodhi, N.S., Posa, M.R.C., Lee, T.M., Bickford, D., Koh, L.P., Brook, B.W., 2010. The state and conservation of Southeast Asian biodiversity. Biodiversity and Conservation 19, 317-328.

Spear, D.M., Foster, W.A., Advento, A.D., Naim, M., Caliman, J.P., Luke, S.H., Snaddon, J.L., Ps, S., Turner, E.C., 2018. Simplifying understory complexity in oil palm plantations is associated with a reduction in 
the density of a cleptoparasitic spider, Argyrodes miniaceus (Araneae: Theridiidae), in host (Araneae: Nephilinae) webs. Ecology and Evolution 8, 1595-1603.

Subías, L.S., Shtanchaeva, U.Y., Arillo, A., 2018. Listado de los ácaros oribátidos (Acariformes, Oribatida) de las diferentes regiones biogeográficas del mundo (6 actzalización) 1939, 1-874.

Sunderland, K.D., Powell, W., Symondson, W.O.C., 2005. Populations and communities, in: Jervis, M.A. (Ed.), Insects as Natural Enemies: A Practical Perspective. Springer Berlin, pp. 299-434.

Swift, M.J., Heal, O.W., Anderson, J.M., 1979. Decomposition in terrestrial ecosystems, Decomposition in terrestrial ecosystems. Univ of California Press.

Syafiq, M., Nur Atiqah, A.R., Ghazali, A., Asmah, S., Yahya, M.S., Aziz, N., Puan, C.L., Azhar, B., 2016. Responses of tropical fruit bats to monoculture and polyculture farming in oil palm smallholdings. Acta Oecologica 74, 11-18.

Symondson, W.O.C., 2012. The molecular revolution: Using polymerase chain reaction based methods to explore the role of predators in terrestrial food webs. Biodiversity and Insect Pests: Key Issues for Sustainable Management 166-184.

Teuscher, M., Gérard, A., Brose, U., Buchori, D., Clough, Y., Ehbrecht, M., Hölscher, D., Irawan, B., Sundawati, L., Wollni, M., Kreft, H., 2016. Experimental biodiversity enrichment in oil-palmdominated landscapes in Indonesia. Frontiers in Plant Science 07, 1-15.

Teuscher, M., Vorlaufer, M., Wollni, M., Brose, U., Mulyani, Y., Clough, Y., 2015. Trade-offs between bird diversity and abundance, yields and revenue in smallholder oil palm plantations in Sumatra, Indonesia. Biological Conservation 186, 306-318.

Thakur, M.P., Eisenhauer, N., 2015. Plant community composition determines the strength of top-down control in a soil food web motif. Scientific Reports 5, 1-6.

Tilman, D., 1977. Resource competition between plankton algae: An experimental and theoretical approach. Ecology 58, 338-348.

Tilman, D., Fargione, J., Wolff, B., D’Antonio, C., Dobson, A., Howarth, R., Schindler, D., Schlesinger, W.H., Simberloff, D., Swackhamer, D., 2001. Forecasting agriculturally driven global environmental change. Science 292, 281-284.

Tilman, D.G., 1986. Resources, competition and the dynamics of plant communities. Plant Ecology.

Tiunov, A.V., 2007. Stable isotopes of carbon and nitrogen in soil ecological studies. Biology Bulletin 34, 395-407.

Tohiran, K.A., Nobilly, F., Zulkifli, R., Maxwell, T., Moslim, R., Azhar, B., 2017. Targeted cattle grazing as an alternative to herbicides for controlling weeds in bird-friendly oil palm plantations. Agronomy for Sustainable Development 37.

Tokeshi, M., 2009. Species coexistence: Ecological and evolutionary perspectives. John Wiley \& Sons. 
Traugott, M., Kamenova, S., Ruess, L., Seeber, J., Plantegenest, M., 2013. Empirically characterising trophic networks: What emerging DNA-based methods, stable isotope and fatty acid analyses can offer, in: Advances in Ecological Research. Academic Press, pp. 177-224.

Tscharntke, T., Clough, Y., Wanger, T.C., Jackson, L., Motzke, I., Perfecto, I., Vandermeer, J., Whitbread, A., 2012. Global food security, biodiversity conservation and the future of agricultural intensification. Biological Conservation 151, 53-59.

UN, 2015. World Population Prospects: The 2015 revision, Volume I: Comprehensive Tables (ST/ESA/SER:A 379. New York.

Vellend, M., 2010. Conceptual synthesis in community ecology. The Quarterly Review of Biology $85,183-$ 206.

Violle, C., Nemergut, D.R., Pu, Z., Jiang, L., 2011. Phylogenetic limiting similarity and competitive exclusion. Ecology Letters 14, 782-787.

Volterra, V., 1926. Fluctuations in the abundance of a species considered mathemarically. Nature 558.

Wada, E., Mizutani, H., Minagawa, M., 1991. The use of stable isotopes for food web analysis. Critical Reviews in Food Science and Nutrition 30(4), 361-371.

Walter, D.E., Proctor, H.C., 2013. Mites: Ecology, evolution and behaviour, Second Edi. ed. Springer Science + Business Media Dordrecht.

Wardle, D.A., Yeates, G.W., Barker, G.M., Bonner, K.I., 2006. The influence of plant litter diversity on decomposer abundance and diversity. Soil Biology and Biochemistry 38, 1052-1062.

White, T.C.R., 1993. The inadequate enviroment. Springer-Verlag Berlin Heidelberg.

Wilcove, D.S., Giam, X., Edwards, D.P., Fisher, B., Koh, L.P., 2013. Navjot's nightmare revisited: Logging, agriculture, and biodiversity in Southeast Asia. Trends in Ecology and Evolution 28, 531-540.

Wilcove, D.S., Koh, L.P., 2010. Addressing the threats to biodiversity from oil-palm agriculture. Biodiversity and Conservation 19, 999-1007.

Zaidi, R.H., Jaal, Z., Hawkes, J., Hemingway, J., Symondson, W.O.C., 1999. Can multiple-copy sequences of prey DNA be detected amongst the gut contents of invertebrate predators? Molecular Ecology 8, 2081-2087.

Zhao, J., Shao, Y., Wang, X., Neher, D. a., Xu, G., Li, Z., Fu, S., 2013. Sentinel soil invertebrate taxa as bioindicators for forest management practices. Ecological Indicators 24, 236-239.

Zimmer, Y., 2010. Competitiveness of rapeseed, soybeans and palm oil. Journal of Oilseed Brassica 1, 8490. 



\section{Chapter II}

\section{Shift in trophic niches of soil microarthropods with}

conversion of tropical rainforest into plantations as indicted by stable isotopes $\left({ }^{15} \mathrm{~N},{ }^{13} \mathrm{C}\right)$

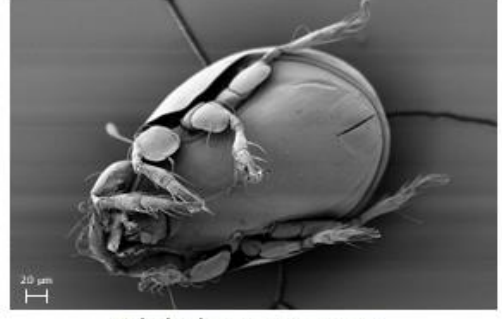

Scheloribates praeincisus

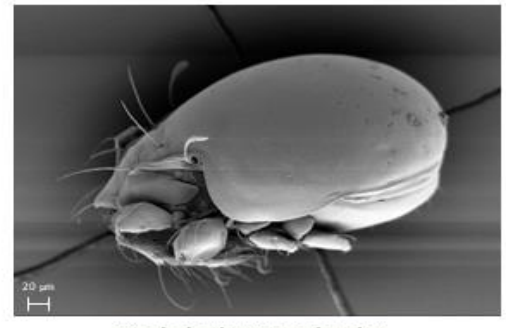

Bischeloribates mahunkai

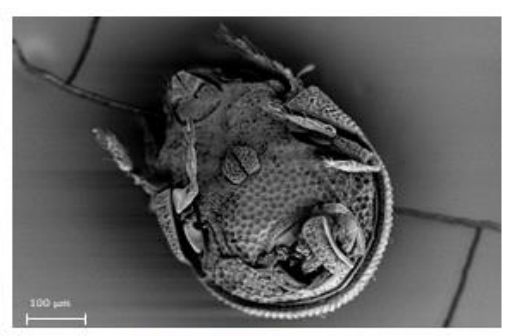

Rostrozetes sp. 1

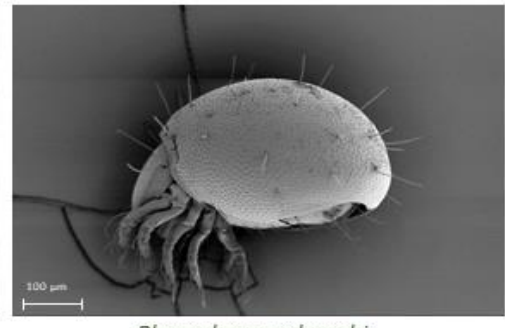

Plonaphacaruskugohi

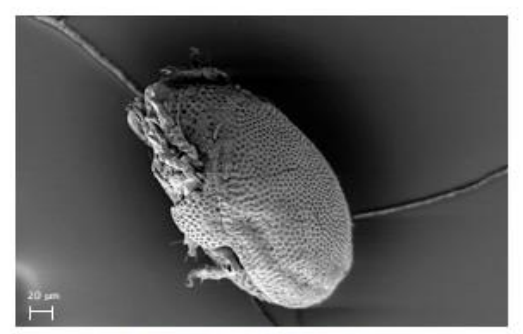

Rostrozetes cf. shibai

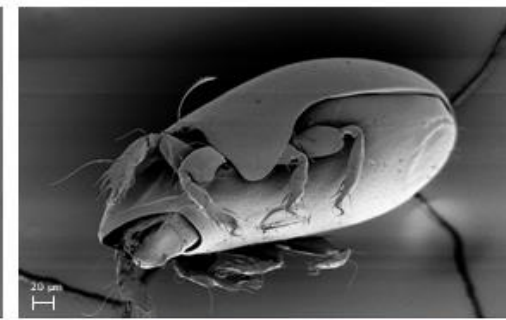

Protoribates paracapucinus

\section{Published in:}

Krause, A., Sandmann, D., Bluhm, S.L., Ermilov, S., Widyastuti, R., Haneda, N.F., Scheu, S., Maraun, M., 2019. Shift in trophic niches of soil microarthropods with conversion of tropical rainforest into plantations as indicted by stable isotopes $\left({ }^{15} \mathrm{~N},{ }^{13} \mathrm{C}\right)$. PLOS

ONE 14.10. e0224520. 



\section{Abstract}

Land-use change is threatening biodiversity worldwide, affecting above and below ground animal communities by altering their trophic niches. However, shifts in trophic niches with changes in land use are little studied and this applies in particular to belowground animals. Oribatid mites are among the most abundant soil animals, involved in decomposition processes and nutrient cycling. We analyzed shifts in trophic niches of six soil-living oribatid mite species with the conversion of lowland secondary rainforest into plantation systems of different land-use intensity (jungle rubber, rubber and oil palm monoculture plantation) in two regions of southwest Sumatra, Indonesia. We measured stable isotope ratios $\left({ }^{13} \mathrm{C} /{ }^{12} \mathrm{C}\right.$ and $\left.{ }^{15} \mathrm{~N} /{ }^{14} \mathrm{~N}\right)$ of single oribatid mite individuals and calculated shifts in stable isotope niches with changes in land use. Significant changes in stable isotope ratios in three of the six studied oribatid mite species indicated that these species shift their trophic niches with changes in land use. The trophic shift was either due to changes in trophic level ( $\delta^{15} \mathrm{~N}$ values), to changes in the use of basal resources $\left(\delta^{13} \mathrm{C}\right.$ values) or to changes in both. The trophic shift generally was most pronounced between more natural systems (rainforest and jungle rubber) on one side and monoculture plantations systems (rubber and oil palm plantations) on the other, reflecting that the shifts were related to land-use intensity. Although trophic niches of the other three studied species did not differ significantly between land-use systems they followed a similar trend. Overall, the results suggest that colonization of very different ecosystems such as rainforest and intensively managed monoculture plantations by oribatid mite species likely is related to their ability to shift their trophic niches, i.e. to trophic plasticity. 


\section{Introduction}

Due to the worldwide growing human population and the associated rising need for food, fuel and fiber, transformation and degradation of landscapes rapidly increased over the last decades (Dirzo and Raven, 2003; Foley et al., 2005; Gibbs et al., 2010; Newbold et al., 2015). This is especially true for tropical regions where rainforest is rapidly and continuously transformed into different land-use systems, such as oil palm and rubber plantations (Sodhi et al., 2010; Wilcove et al., 2013; Meijide et al., 2018). Within the humid tropics Southeast Asia is one of the hotspots of recent deforestation with the highest loss of primary rainforest occurring in Sumatra (Indonesia) on average 0.40 Mha per year between 2009 and 2011 (Laumonier et al., 2010; Miettinen et al., 2011; Margono et al., 2014). Notably, these hotspots of deforestation are located in regions with the highest biodiversity and highest level of endemism worldwide (Myers et al., 2000; Sodhi et al., 2010; Drescher et al., 2016). It has been shown that land-use intensification in the tropics affects diversity and biomass of soil animals including centipedes, earthworms and oribatid mites (Lavelle et al., 1997, 2006; Erdmann et al., 2007; Whalen and Sampedro, 2010; Wilcove et al., 2013; Klarner et al., 2017), which in turn may affect decomposition and nutrient cycling provided by these organisms. Oribatid mites are among of the most abundant soil arthropods worldwide and involved in decomposition processes and nutrient cycling (Maraun and Scheu, 2000; Bardgett, 2005). There are more than 11,000 described species (Subías et al., 2018) with the true number of species likely exceeding 50,000 (Walter and Proctor, 2013). Oribatid mites can reach densities of up to 200,000 ind./ $\mathrm{m}^{2}$ in forest soils of temperate regions whereas in tropical regions densities typically are in the range of $30,000-40,000$ ind./ $\mathrm{m}^{2}$ (Maraun and Scheu, 2000; Maraun et al., 2007; 
Scheu et al., 2008). Oribatid mites are trophically diverse and stable isotope analyses suggest that they span over about four trophic levels including lichen feeders, fungal feeders, primary and secondary decomposers as well as predators/scavengers (Schneider et al., 2004; Illig et al., 2005; Maaß et al., 2015).

Trophic position and trophic interactions characterize species and their role in ecosystem functioning and services. For many ecosystem functions, such as decomposition, nutrient cycling, carbon sequestration, primary production and crop yield, the soil decomposer system is essential (Hooper et al., 2005; Powers et al., 2009). The trophic structure of animal communities can be evaluated by analyzing natural variations in ${ }^{15} \mathrm{~N} /{ }^{14} \mathrm{~N}$ and ${ }^{13} \mathrm{C} /{ }^{12} \mathrm{C}$ ratios (Wada et al., 1991; Boecklen et al., 2011; Potapov et al., 2019). Animal tissue typically is enriched in ${ }^{15} \mathrm{~N}$ as compared to their food resource by about 3 and for ${ }^{13} \mathrm{C}$ by about $1 \delta$ unit per trophic level, however, the enrichment may vary between trophic guilds and also between taxa (Post, 2002; McCutchan et al., 2003; Potapov et al., 2019). Thereby, ${ }^{15} \mathrm{~N}$ values allow estimating trophic levels (DeNiro and Epstein, 1978; Kreipe et al., 2015), whereas ${ }^{13} \mathrm{C}$ is used to identify basal food resources since ${ }^{13} \mathrm{C}$ values change little across trophic levels (Wada et al., 1991). Stable isotopes have been used widely to analyze trophic niches of soil invertebrates (Scheu and Falca, 2000; Halaj et al., 2005; Maraun et al., 2007, 2011; Tiunov, 2007) including earthworms (Martin et al., 1992), ants (Rosumek et al., 2018), springtails (Chahartaghi et al., 2005), gamasid mites (Klarner et al., 2013) and oribatid mites (Schneider et al., 2004; Erdmann et al., 2007; Maraun et al., 2011). However, until today stable isotopes rarely have been used to investigate how trophic niches of soil animal taxa are affected by changes in land-use (Lagerlöf et al., 2017; Minor et al., 2017). 
Forest transformation and land-use intensification strongly affect animal and plant taxa, and the changes typically are associated by the loss of species (Koh and Wilcove, 2008; Flynn et al., 2009; Barnes et al., 2014). An important mechanism to cope with environmental alterations such as land-use change is to respond in a plastic way by shifting trophic niches and adapt to the resources available locally. Trophic plasticity, therefore, may prevent extinction and thereby support biodiversity in converted ecosystems. Until today ecological plasticity mostly has been investigated in aquatic taxa, such as fish (Bowen and Allanson, 1982; Almeida et al., 2012; Drymon et al., 2012) and gastropods (Riera, 2010). These studies, however, focused on changes in morphology and behavior due to changing environmental factors rather than on trophic plasticity. Few studies investigated trophic shifts in soil animals. Klarner et al. (2017) showed that centipede predators switch their diet from feeding on secondary decomposers in rainforest to less

${ }^{13} \mathrm{C}$ enriched prey in oil palm plantations. Investigating variations in stable isotope ratios in oribatid mites from temperate ecosystems Gan et al. (2014) found oribatid mite species numbers to decline in global change scenarios since trophic specialists will likely go extinct. However, these findings may have been biased as the stable isotope data they used were based on pooled individuals which reduced intraspecific variability. Measuring pooled individuals may reduce the variation in the data and thereby erroneously point to specialist feeding. These restrictions may be circumvented as recent improvements allow to measure stable isotope ratios of small samples (Langel and Dyckmans, 2014) including single individuals of soil microarthropod species.

The current study formed part of the interdisciplinary project "Ecological and socioeconomic functions of tropical lowland rainforest transformation systems" 
(EFForTS), established in Jambi Province, southwest Sumatra (Indonesia) (Drescher et al., 2016). By measuring natural variations in ${ }^{15} \mathrm{~N} /{ }^{14} \mathrm{~N}$ and ${ }^{13} \mathrm{C} /{ }^{12} \mathrm{C}$ ratios of individual specimens, we analyzed trophic niches of six soil living oribatid mite species occurring in rainforest and three major rainforest-transformation systems in Southeast Asia, i.e. rubber agroforest ("jungle rubber"), and rubber and oil palm monoculture plantations. We will further refer to those four system in the following as the four land-use systems (rain forest, jungle rubber, rubber, oil palm). We hypothesized that (1) oribatid mite species adapt to environmental changes in transformed ecosystems by shifting their trophic niche, and that (2) the shifts are more pronounced in ${ }^{13} \mathrm{C}$ than in ${ }^{15} \mathrm{~N}$ as changes in land-use systems more strongly affect basal resources (as indicated by ${ }^{13} \mathrm{C}$ ) than trophic levels (as indicated by $\left.{ }^{15} \mathrm{~N}\right)$.

\section{Material and Methods}

\section{Study sites}

Soil samples were taken in two regions of Jambi Province, Bukit Duabelas ( $2^{\circ} 0^{\prime} 57^{\prime \prime} \mathrm{S}, 120^{\circ}$ $\left.45^{\prime} 12^{\prime \prime} \mathrm{E}\right)$ and Harapan $\left(1^{\circ} 55^{\prime} 40^{\prime \prime} \mathrm{S}, 103^{\circ} 15^{\prime} 33^{\prime \prime} \mathrm{E}\right)$. In each region four different landuse systems were investigated: rainforest, jungle rubber, rubber and oil palm plantations (Drescher et al., 2016). Rainforest sites were secondary rainforest which had been selectively logged about 20 - 30 years ago. Jungle rubber originated from enrichment of rainforest with rubber trees (Hevea brasiliensis) and includes rainforest trees. Jungle rubber sites were used to represent rainforest conversion systems of low land-use intensity lacking fertilizer input and herbicide application. Rubber as well as oil palm (Elaeis guineensis) monocultures were intensively managed plantations of an average age 
of 13 to 14 years. These systems were chosen to represent high land-use intensity plantation systems. Four replicates of each land-use system (rainforest, jungle rubber, rubber and oil palm plantations) in the two landscapes (Bukit Duabelas, Harapan) were established, resulting in 32 plots; in each plot samples were taken from three subplots, resulting in a total of 96 samples. Each plot spanned $50 \times 50 \mathrm{~m}$ and the subplots $5 \times 5 \mathrm{~m}$ (Drescher et al., 2016). For more details of the study site see Drescher et al. (2016). At both landscapes (Bukit Dubaelas, Harapan) acrisols dominated. Soils with a clay texture dominated in Bukit Duabelas, whereas soils with a sandy loam texture dominated in Harapan. All study sites were at similar altitudes varying between 50 and $100 \mathrm{~m}$ a.s.l. (Guillaume et al., 2015).

\section{Sampling, extraction and species determination}

Samples of $16 \times 16 \mathrm{~cm}$ comprising the litter layer and the underlying $0-5 \mathrm{~cm}$ of the mineral soil were taken in October/November 2013. The two layers were separated, transported to the laboratory and extracted by heat (Kempson et al., 1963). Oribatid mites were determined to species/morphospecies level using Balogh \& Balogh (Balogh and Balogh, 2012) and ascribed to feeding guilds including lichen feeders, primary decomposer, secondary decomposer/fungal feeders and predators/scavengers based on Maraun et al. (2011). Species and morphospecies were documented by taking pictures, linked with morphological traits and species identification numbers (species ID), and included into Ecotaxonomy database (http://ecotaxonomy.org/). Animals were stored in $70 \%$ ethanol until further analysis. 


\section{Stable isotope analysis}

The six most abundant oribatid mite species of 220 species overall (D. Sandmann, unpubl. data) occurring in each of the land-use systems in both landscapes were selected for stable isotope analysis, i.e. Plonaphacarus kugohi (Aoki, 1959) (Ecotaxonomy species ID 405729), Protoribates paracapucinus (Mahunka, 1988) (Ecotaxonomy species ID 405671), Scheloribates praeincisus (Berlese, 1910) (Ecotaxonomy species ID 405449), Bischeloribates mahunkai Subías, 2010 (Ecotaxonomy species ID 405450), Rostrozetes cf. shibai (Aoki, 1976) (Ecotaxonomy species ID 405389), und Rostrozetes sp. 1 (Ecotaxonomy species ID 405478). In total, 100 individuals of S. praeincisus, 75 of $R$. cf. shibai, 54 of $P$. paracapucinus, 44 of $B$. mahunkai, 19 of $P$. kugohi and 13 of Rostrozetes sp. 1 were analyzed.

For calibration of oribatid mite stable isotope values we measured stable isotope values of leaf litter taken from the dried litter material after extraction of the animals (ca. $2.5 \mathrm{~g}$ per sample). Prior to stable isotope analysis the litter was dried at $60^{\circ} \mathrm{C}$ for $24 \mathrm{~h}$ and ground in a ball mill (Retsch Mixer Mill MM200, Haan, Germany). For measuring stable isotope values of Oribatida, single individuals were used. Oribatid mite specimens were dried at $60^{\circ} \mathrm{C}$ for $24 \mathrm{~h}$ and weighed into tin capsules. Between one and three individuals from each of the transformation systems of both landscapes were measured (Table S1). Stable isotope values were determined by a coupled system of an elemental analyzer (NA 1500, Carlo Erba, Milan, Italy) and a mass spectrometer (MAT 251, Finnigan, Bremen, Germany) adopted for the analysis of small sample sizes (Langel and Dyckmans, 2014). The content of ${ }^{13} \mathrm{C}$ and ${ }^{15} \mathrm{~N}$ was expressed using the $\delta$ notation with $\delta \mathrm{X}(\%)=\left(\mathrm{R}_{\text {sample }}-\mathrm{R}_{\text {standard }}\right) / \mathrm{R}_{\text {standard }}$ $x$ 1000, with $X$ representing the target isotope $\left({ }^{15} \mathrm{~N}\right.$ or $\left.{ }^{13} \mathrm{C}\right)$ and $\mathrm{R}_{\text {sample }}$ and $\mathrm{R}_{\text {standard }}$ the 
${ }^{13} \mathrm{C} /{ }^{12} \mathrm{C}$ and ${ }^{15} \mathrm{~N} /{ }^{14} \mathrm{~N}$ ratios, respectively. As standard for ${ }^{13} \mathrm{C}$ and ${ }^{15} \mathrm{~N}$ analyses Vienna PD Belemnite (Coplen et al., 2002) and nitrogen in atmospheric air were used, respectively. Acetanilid was used as internal standard.

\section{Statistical analysis}

Means of $\delta^{13} \mathrm{C}$ and $\delta^{15} \mathrm{~N}$ values of the three litter samples per plot were used as plotspecific litter $\delta^{13} \mathrm{C}$ and $\delta^{15} \mathrm{~N}$ values. Differences between plot-specific litter $\delta^{13} \mathrm{C}$ and $\delta^{15} \mathrm{~N}$ values and the overall mean litter $\delta^{13} \mathrm{C}$ and $\delta^{15} \mathrm{~N}$ values (across all plots, landscapes and land-use systems) were used to adjust individual $\delta^{13} \mathrm{C}$ and $\delta^{15} \mathrm{~N}$ values of oribatid mites per plot which allowed direct comparison of stable isotope values of oribatid mites across plots. The procedure resembles the calculation of $\Delta$ values but allows to present data relative to the overall mean litter $\delta^{13} \mathrm{C}$ and $\delta^{15} \mathrm{~N}$ values. Calibrated data were used for all further analysis. Based on these values, average $\delta^{13} \mathrm{C}$ and $\delta^{15} \mathrm{~N}$ values of oribatid mite species across plots, land-use systems and landscapes were calculated. Further variations in $\delta^{13} \mathrm{C}$ and $\delta^{15} \mathrm{~N}$ values within species across the four different land-use systems were inspected using the standard deviation (SD) of stable isotope values within species per plot (Table S2). Oribatid mites were ascribed to trophic levels assuming a trophic enrichment of ${ }^{15} \mathrm{~N}$ by $3.4 \%$ per trophic level except for primary decomposers for which we used a value of $1.7 \%$ as they typically are less enriched than consumers of higher trophic level (Vanderklift and Ponsard, 2003; Potapov et al., 2019).

Statistical analyses were performed using R v 3.5.2 (R Core Team, 2018) with R studio interface (RStudio, Inc.). Normality and variance homogeneity were inspected using diagnostic plots. We did not check for overfitting in the model with all species but as we 
also inspected each species separately and found stable isotope values to vary significantly with land-use systems overfitting in the model with all species is unlikely. Differences in the variation of $\delta^{13} \mathrm{C}$ and $\delta^{15} \mathrm{~N}$ values across land-use systems were inspected using a linear mixed effects model as implemented in the Ime4 package (Bates et al., 2015). Fixed factors were species identity and land-use system, with 'PlotID' included as random factor. Significant differences between fixed factors were inspected using the Anova function. Differences in each $\delta^{13} \mathrm{C}$ and $\delta^{15} \mathrm{~N}$ values between species were inspected using a linear mixed effects model as implemented in the $n$ lme package (Pinheiro et al., 2007). Species identity and land-use systems were used as fixed factors and a random factor 'PlotID' was included to account for multiple sampling per plot. The significance of the fixed factors were inspected using the Anova function. Pairwise differences between the different landuse systems were inspected using the glht package (Hothorn et al., 2008) with 'Tukey's pairwise contrasts'. Data provided in text and figures are given as means \pm 1 SD.

\section{Results}

Diagnostic plots of standard deviation against mean $\delta^{13} \mathrm{C}$ and $\delta^{15} \mathrm{~N}$ showed that the data were distributed normally. Stable isotope values of the combined dataset differed significantly between the six oribatid mite species across land-use systems $\left(\chi^{2}{ }_{5,3}=60.56\right.$, $p<0.001$ for ${ }^{13} \mathrm{C}$, and $\chi^{2}{ }_{5,3}=78.74, p<0.0001$ for $\left.{ }^{15} \mathrm{~N}\right)$. Variation in stable isotope values within species differed significantly between land-use systems for ${ }^{15} \mathrm{~N}$ but not for ${ }^{13} \mathrm{C}\left(\chi^{2}{ }_{3,4}\right.$ $=8.53, p=0.036$ and $\chi^{2} 3,4=3.85, p=0.279$, respectively; Fig. S3-S4). Variations in $\delta^{15} \mathrm{~N}$ values were similar in rainforest, jungle rubber and rubber plantations (SD of $-0.10 \%$, $0.67 \%$ and $0.76 \%$, respectively) but significantly higher in oil palm plantations (SD of 
$0.62 \%$ ). Individual mixed effects models for each $\delta^{13} \mathrm{C}$ and $\delta^{15} \mathrm{~N}$ values in these species indicated that these shifts were due to changes in $\delta^{15} \mathrm{~N}$ values in S. praeincisus and $R$. cf. shibai $\left(\chi^{2}{ }_{3}=17.14, p<0.001\right.$ for S. praeincisus, $\chi^{2}{ }_{3}=10.36, p=0.016$ for $R$. cf. shibai $)$, with $\delta^{15} \mathrm{~N}$ values being lowest in rainforest and highest in rubber plantations in S. praeincisus, and being highest in jungle rubber and similarly low in rubber and oil palm plantations as well as in rainforest in $R$. cf. shibai (Tukey's HSD test; rubber vs. rainforest $p<0.001$ for $S$. praeincisus, jungle rubber vs. rainforest $p=0.025$, jungle rubber vs. oil palm $p=0.040$, jungle rubber vs. rubber $\mathrm{p}=0.022$ for $R$. cf. shibai; Fig. 1).

Scheloribates praeincisus (100 measurements)

Rostrozetessp. 1 (13 measurements)

Rostrozetescf. shibai (75 measurements)

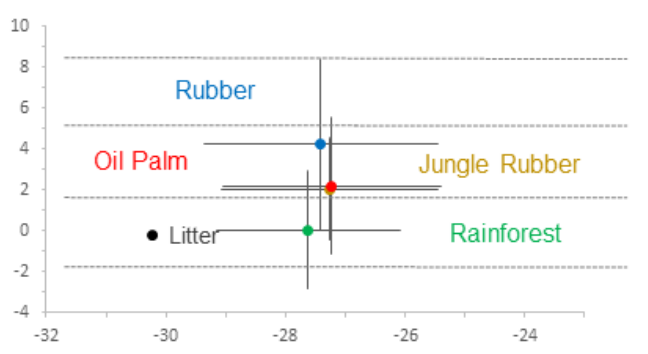

Predator

Secondary Decomposer

Primary Decomposer

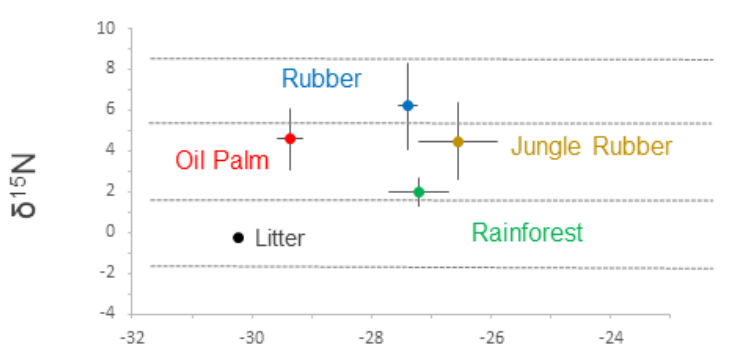

Predator Secondary Decomposer Primary Decomposer

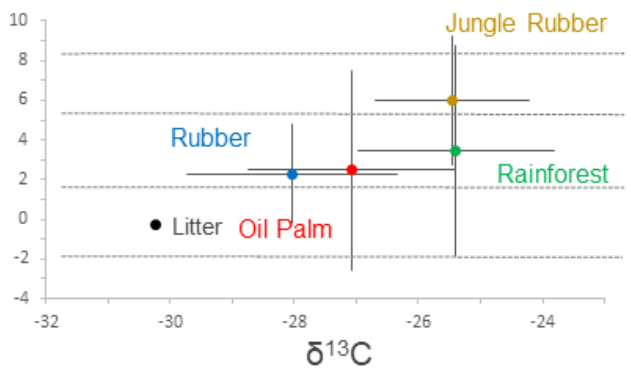

Figure 1: Stable isotope $\left(\delta^{13} \mathrm{C}\right.$ and $\left.\delta^{15} \mathrm{~N}\right)$ values of oribatid mite species [Scheloribates praeincisus (Berlese, 1910), Rostrozetes sp. 1 and Rostrozetes cf. shibai (Aoiki, 1976)] in the four land-use systems studied (rainforest, jungle rubber, rubber and oil palm plantations). Means with standard 
deviations; numbers of measurements per species are given in brackets. The average stable isotope value of litter used for calibration (see Methods) is given as reference. Dashed horizontal lines reflect boundaries of trophic levels (primary decomposers, secondary decomposers and predators; see Methods). For statistical analysis see text.

In addition to $\delta^{15} \mathrm{~N}$, shifts in the trophic niche of $R$. cf. shibai with land-use system also was due to changes in $\delta^{13} \mathrm{C}$ values and this was also true for Rostrozetes sp. $1\left(\chi^{2}{ }_{3}=28.59, p<\right.$ 0.001 for Rostrozetes sp. $1 ; \chi^{2}{ }_{3}=13.77, p=0.003$ for $R$. cf. shibai). $\delta^{13} \mathrm{C}$ values of Rostrozetes sp. 1 in oil palm plantations were significantly lower than those in each of the other land-use systems, whereas $\delta^{13} \mathrm{C}$ values of $R$. cf. shibai were significantly lower in oil palm and rubber plantations than in jungle rubber and rainforest (Tukey's HSD test; oil palm vs. rainforest $p=0.008$, oil palm vs. jungle rubber $p<0.001$, oil palm vs. rubber $p=$ 0.012 for Rostrozetes sp. 1 ; rubber vs. rainforest $p=0.018$, rubber vs. jungle rubber $=0.018$ for $R$. cf. shibai). Although not significant, $\delta^{15} \mathrm{~N}$ values for Rostrozetes sp. 1 also varied between land-use systems. Mean ${ }^{15} \mathrm{~N}$ values classified Rostrozetes sp. 1 as secondary decomposer in rainforest, jungle rubber and oil palm plantations, but as predator/scavenger in rubber plantations.

Although stable isotope values of the other three studied oribatid mite species ( $B$. mahunkai, P. kugohi and P. paracapucinus) did not differ significantly among the four landuse systems (Anova; $p>0.05$ for all three species), their position varied in isotope space in particular along the $\delta^{13} \mathrm{C}$ axis, resulting in a separation of rainforest and jungle rubber from rubber and oil palm plantations in each of the species thereby resembling the shift in Rostrozetes sp. 1 and R. cf. shibai (Fig. S1). 


\section{Discussion}

Based on stable isotope analysis trophic niches of oribatid mites - and soil arthropods in general - have been assumed to vary little at the landscape level (Scheu and Falca, 2000; Schneider et al., 2004; Illig et al., 2005; Erdmann et al., 2007; Pollierer et al., 2009; Fischer et al., 2010; Perdomo et al., 2012; Gan et al., 2014) as well as between forest types (Scheu and Falca, 2000; Schneider et al., 2004). The results of our study are in contrast to these earlier studies where oribatid mite trophic niches were proposed to be rather stable and narrow.

\section{Trophic niches of species}

The six studied oribatid mite species which occurred in each of the land-use systems spanned three trophic levels including primary and secondary decomposers as well as predators/scavengers, which is conform to earlier studies (Schneider et al., 2004; Illig et al., 2005; Maraun et al., 2011). Additionally, intraspecific variation in $\delta^{15} \mathrm{~N}$ values were significantly higher in oil palm plantations than in the other three land-use systems. Presumably, this was due to the lack of primary decomposers in oil palm plantations (which only feed on one trophic level, plant litter) and the presence of only higher trophic level species such as secondary decomposers and predators/scavengers, which are more likely to engage in omnivory and intraguild predation. Bischeloribates mahunkai grouped as predator/scavenger in rainforest, rubber and oil palm plantations, but as secondary decomposer in jungle rubber. Protoribates paracapucinus grouped as secondary decomposer in rainforest and jungle rubber, but as predator in rubber and oil palm plantations. Scheloribates praeincisus and P. kugohi uniformly grouped as primary 
decomposers in rainforest and as secondary decomposers in the other three land-use systems. Although predominantly grouped as secondary decomposers, Rostrozetes sp. 1 and $R$. cf. shibai were grouped as predators/scavengers in rubber plantations and jungle rubber. Overall, the results confirm that oribatid mites predominantly function as secondary decomposers feeding on microorganisms, in particular fungi, however, they also indicate that in part they feed on animal prey, presumably nematodes (Heidemann et al., 2011, 2014), or live as scavengers. High trophic position in B. mahunkai is conform to the suggestion of Rockett (Rockett, 1980) that many species of Scheloribatida live as predators. However, lower trophic position of S. praeincisus suggests that this does not apply uniformly to Scheloribatida as indicated previously (Bluhm et al., 2015). Grouping of Rostrozetes sp. 1 and R. cf. shibai as secondary decomposers (and in part as predators) was unexpected since another species of Rostrozetes, $R$. ovulum, was shown to live as primary decomposer in a tropical montane rainforest in Ecuador (Illig et al., 2005). Plonaphacarus kugohi had the lowest ${ }^{15} \mathrm{~N}$ values and in part was grouped as primary decomposer indicating that this species feeds on litter and microorganisms confirming that Phthiracaridae/Euphthiracaridae often function as primary decomposers (Maraun et al., 2011). Primary decomposers are characterized by low fractionation of ${ }^{15} \mathrm{~N}$ which likely is related to "protein sparing", i.e. the retaining of assimilated $\mathrm{N}$ in body tissue rather than excreting it due to low nitrogen supply in litter (Swift et al., 1979; Castellini and Rea, 1992; Gannes et al., 2007; Pollierer et al., 2009). However, recent laboratory studies question that this uniformly applies to oribatid mites (Heethoff and Scheu, 2016). Furthermore, high $\delta^{13} \mathrm{C}$ values of $P$. kugohi indicate that this species incorporates calcium carbonate in their exoskeleton (Norton and Behan-Pelletier, 1991; Pachl et al., 2012). 


\section{Shift in trophic niches with land use}

Conform to our hypotheses, the studied oribatid mite species shifted their trophic niche with transformation of rainforest into plantation systems, however, this was only significant in three (S. praeincisus, R. cf. shibai and Rostrozetes sp. 1) of the six studied species, but in trend it also applied to the other three species. This indicates that the ability of the studied oribatid mite species to colonize very different ecosystems at least in part is due to the fact that they are trophically plastic and adapt to the changed environmental conditions in converted ecosystems by shifting their trophic niche. $\Delta^{15} \mathrm{~N}$ values of $S$. praeincisus and $R$. cf. shibai differed between the four land-use systems, e.g. $\delta^{15} \mathrm{~N}$ values of S. praeincisus in rubber plantations were almost $4 \%$ higher than in rainforest, whereas $\delta^{15} \mathrm{~N}$ values of $R$. cf. shibai in jungle rubber were almost $4 \%$ higher than in the other three land-use systems. This indicates that $S$. praeincisus as well as $R$. cf. shibai alter their resource use with conversion of rainforest/jungle rubber into plantations by shifting its trophic position. S. praeincisus altered its trophic position from primary decomposer in rainforest to secondary decomposer in plantations, presumably feeding almost exclusively on fungi in the latter. $R$. cf. shibai shifted its trophic position from secondary decomposer in rubber, oil palm and rainforest to predator/scavenger in jungle rubber. Notably, $S$. praeincisus and $P$. kugohi were the only species classified as primary decomposers and they only functioned as primary decomposers in rainforest. This is consistent with earlier studies stressing the lack or scarcity of primary decomposers among oribatid mite species in tropical forest ecosystems (Illig et al., 2005). The scarcity of primary decomposers likely is related to the poor litter quality in rainforest ecosystems (Butenschoen et al., 2014; Krashevska et al., 2017; Marian et al., 2017), and the results of this study indicates that 
this is aggravated by conversion of rainforest into plantations as none of the species studied was classified as primary decomposer in plantations. This suggests that the conversion of rainforest into plantation systems aggravates the shortage and poor quality of litter resources for the decomposer community (Teuscher et al., 2016; Klarner et al., 2017).

Rostrozetes sp. 1 as well as $R$. cf. shibai responded in a similar way to the conversion of rainforest into plantation systems as indicated by the shift in $\delta^{13} \mathrm{C}$ values, i.e. changes in the basal resources they are using. In both species $\delta^{13} \mathrm{C}$ values were similar in rainforest and jungle rubber and different from that in oil palm (Rostrozetes sp. 1) and oil palm and rubber plantations ( $R$. cf. shibai). Soil animals typically are enriched by $3-4 \delta$ units in ${ }^{13} \mathrm{C}$ as compared to litter due to the "detrital shift" (Pollierer et al., 2009; Potapov et al., 2019), and this also was true in the species studied. In Rostrozetes sp. 1 and $R$. cf. shibai this detrital shift was most pronounced in rainforest and jungle rubber. The more pronounced detrital shift in rainforest and jungle rubber likely reflects a shift in the use of plant litter carbon compounds towards compounds which are easy to access, such as sugars, proteins and (hemi)cellulose, rather than compounds which are difficult to access and have lower $\delta^{13} \mathrm{C}$ values such as lignin (Gleixner et al., 1993; Hobbie and Werner, 2004; Bowling et al., 2008; Pollierer et al., 2009; Potapov et al., 2019).

Although stable isotope values in the other three studied oribatid mite species ( $B$. mahunkai, P. kugohi and P. paracapucinus) also varied, these variations were not significant suggesting that their shifts in trophic niches were less pronounced. Notably, in particular the trophic position of B. mahunkai, classified predominantly as predator, varied little between land-use systems suggesting that this species is unable to switch from 
animal prey (or carcasses) to feeding on litter or microorganisms. Conform to the significant changes in trophic niches in S. praeincisus, Rostrozetes sp. 1 and R. cf. shibai, the trophic niches of $B$. mahunkai, $P$. kugohi and $P$. paracapucinus were more similar in rainforest and jungle rubber and separate from those in oil palm and rubber. Also, conform to the former three species, the detrital shift in $\delta^{13} \mathrm{C}$ in B. mahunkai, $P$. kugohi and $P$. paracapucinus was less pronounced in rubber and oil palm plantations suggesting that detritivores in these systems benefit from high quality litter of the herb layer (see above). Other studies of oribatid mite families and superfamilies showed results similar to our study on species-level (Minor et al., 2017). However, although changes in land use on the trophic structure of soil animals may also be detected at courser taxonomic lever than species, our results indicate that land-use change even affects trophic variability within species, suggesting that to fully appreciate changes in niche space with changes in land use needs high taxonomic resolution and even the level of individuals within species (Somerfield and Clarke, 1995; Hirst, 2006; Heino, 2014; Hanna et al., 2015).

We assumed the shift in trophic niches to be mainly due to changes in the use of basal resources rather than trophic level. Contrary to this hypothesis, the significant shifts in trophic niches in S. praeincisus and Rostrozetes sp. 1 and R. cf. shibai were due to both changes in the use of basal resources (Rostrozetes sp. 1 and $R$. cf. shibai) as well as changes in trophic position (S. praeincisus and R. cf. shibai). Notably, the shift in $\delta^{15} \mathrm{~N}$ values in both of the latter species occurred towards higher trophic positions suggesting that they switched towards including prey of higher trophic levels in converted ecosystems. Overall, this indicates that in particular in primary and secondary decomposers trophic plasticity plays an important role for their ability to colonize a wide range of habitats. 


\section{Conclusions}

Of the six species studied occurring across the four land-use systems we detected significant shifts in trophic niches in three of them, but trophic niches of the other three species also varied in a similar way. Notably, the shifts were due to both changes in trophic position ( $\left({ }^{15} \mathrm{~N}\right.$ values) as well as changes in the use of basal resources $\left(\delta^{13} \mathrm{C}\right.$ values) with the shift in trophic position towards higher trophic levels in transformed ecosystems. The observed shifts in trophic niches are conform to the view that oribatid mites are generalist feeders able to change their diet according to changes in resource availability. Notably, the shifts in trophic niches were most pronounced between more natural systems (rainforest and jungle rubber) and high intensity land-use systems (rubber and oil palm plantations). Overall, the results suggest that the ability of oribatid mite species to colonize a wide range of land-use systems including rainforest and monoculture plantations is likely based on trophic plasticity and the ability to shift both their trophic level and the basal resource they rely on.

\section{Acknowledgments}

\section{Funding}

This study was funded (or funded in part) by the Deutsche Forschungsgemeinschaft (DFG, German Research Foundation) - project number 192626868 - SFB 990 (and/or the Ministry of Research, Technology and Higher Education (Ristekdikti)) in the framework of the collaborative German - Indonesian research project CRC990. 


\section{Field work permissions}

The study was conducted in the framework of the German-Indonesian research project "Ecological and socio-economic functions of tropical lowland rainforest transformation systems" (EFForTS) based on the research permits no. 332/SIP/FRP/SM/IX/2012, 389/SIP/FRP/SM/X/2013 and 145/SIP/FRP/SM/V/2013 issued by the State Ministry of Research and Technology of the Republic of Indonesia (RISTEK). Samples were based on collection permit no. S.07/KKH-2/2013 issued by the Indonesian Ministry of Forestry (PHKA). Sample export for analysis in Germany was based on permit no. 125/KKH5/TRP/2014 issued by the Ministry of Forestry of the Republic of Indonesia.

\section{Sample collection and determination}

We thank Bernhard Klarner for collecting the samples as well as Svenja Meyer, Kristina Richter, Anneliese Beckendorff and Melissa Jüds for help in determining oribatid mites, and Anton Potapov for commenting on an earlier version of the paper. Furthermore, we thank the Kompetenzzentrum Stabile Isotope Göttingen (KOSI) for the measurement of stable isotopes.

\section{References}

Almeida, D., Almodóvar, A., Nicola, G.G., Elvira, B., Grossman, G.D., 2012. Trophic plasticity of invasive juvenile largemouth bass Micropterus salmoides in Iberian streams. Fisheries Research 113, 153-158.

Balogh, P., Balogh, J., 2012. The soil mites of the world: Vol. 3: Oribatid mites of the neotropical region II, 3rd ed. Elsevier.

Bardgett, R., 2005. The biology of soil: A community and ecosystem approach. Oxford University Press. 
Barnes, A.D., Jochum, M., Mumme, S., Haneda, N.F., Farajallah, A., Widarto, T.H., Brose, U., 2014. Consequences of tropical land use for multitrophic biodiversity and ecosystem functioning. Nature Communications 5, 1-7.

Bates, D., Maechler, M., Bolker, B., Walker, S., 2015. Fitting Linear Mixed-Effects Models Using Ime4. Journal of Statistical Software 67, 1-48.

Bluhm, C., Scheu, S., Maraun, M., 2015. Oribatid mite communities on the bark of dead wood vary with log type, surrounding forest and regional factors. Applied Soil Ecology 89, 102-112.

Boecklen, W.J., Yarnes, C.T., Cook, B.A., James, A.C., 2011. On the use of stable isotopes in trophic ecology. Annual Review of Ecology, Evolution, and Systematics 42, 411-440.

Bowen, S.H., Allanson, B.R., 1982. Behavioral and trophic plasticity of juvenile Tilapia mossambica in utilization of the unstable littoral habitat. Environmental Biology of Fishes 7, 357-362.

Bowling, D.R., Pataki, D.E., Randerson, J.T., 2008. Carbon isotopes in terrestrial ecosystem pools and $\mathrm{CO}_{2}$ fluxes. New Phytologist 178, 24-40.

Butenschoen, O., Krashevska, V., Maraun, M., Marian, F., Sandmann, D., Scheu, S., 2014. Litter mixture effects on decomposition in tropical montane rainforests vary strongly with time and turn negative at later stages of decay. Soil Biology and Biochemistry 77, 121-128.

Castellini, M. a., Rea, L.D., 1992. The biochemistry of natural fasting at its limits. Experientia 48, 575-582.

Chahartaghi, M., Langel, R., Scheu, S., Ruess, L., 2005. Feeding guilds in Collembola based on nitrogen stable isotope ratios. Soil Biology and Biochemistry 37, 1718-1725.

Coplen, T.B., Hopple, J.A., Boehike, J.K., Peiser, H.S., Rieder, S.E., 2002. Compilation of minimum and maximum isotope ratios of selected elements in naturally occurring terrestrial materials and reagents.

DeNiro, M.J., Epstein, S., 1978. Influence of diet on the distribution of nitrogen isotopes in animals. Geochimica et Cosmochimica Acta 45, 341-351.

Dirzo, R., Raven, P.H., 2003. Global state of biodiversity and loss. Annual Review of Environment and Resources 28, 137-167.

Drescher, J., Rembold, K., Allen, K., Beckscha, P., Buchori, D., Clough, Y., Faust, H., Fauzi, A.M., Gunawan, D., Hertel, D., Irawan, B., Jaya, I.N.S., Klarner, B., Kleinn, C., Knohl, A., Kotowska, M.M., Krashevska, V., Krishna, V., Leuschner, C., Lorenz, W., Meijide, A., Melati, D., Steinebach, S., Tjoa, A., Tscharntke, T., Wick, B., Wiegand, K., Kreft, H., Scheu, S., 2016. Ecological and socio-economic functions across tropical land use systems after rainforest conversion. Philosophical Transactions of the Royal Society of London. Series B, Biological Sciences 231, 1-7.

Drymon, J.M., Powers, S.P., Carmichael, R.H., 2012. Trophic plasticity in the Atlantic sharpnose shark (Rhizoprionodon terraenovae) from the north central Gulf of Mexico. Environmental Biology of Fishes 95, 21-35.

Erdmann, G., Otte, V., Langel, R., Scheu, S., Maraun, M., 2007. The trophic structure of bark-living oribatid mite communities analysed with stable isotopes $\left({ }^{15} \mathrm{~N},{ }^{13} \mathrm{C}\right)$ indicates strong niche differentiation. Experimental and Applied Acarology 41, 1-10. 
Fischer, B.M., Schatz, H., Maraun, M., 2010. Community structure, trophic position and reproductive mode of soil and bark-living oribatid mites in an alpine grassland ecosystem. Experimental and Applied Acarology 52, 221-237.

Flynn, D.F.B., Gogol-Prokurat, M., Nogeire, T., Molinari, N., Richers, B.T., Lin, B.B., Simpson, N., Mayfield, M.M., DeClerck, F., 2009. Loss of functional diversity under land use intensification across multiple taxa. Ecology Letters 12, 22-33.

Foley, J.A., Defries, R., Asner, G.P., Barford, C., Bonan, G., Carpenter, S.R., Chapin, S.F., Coe, M.T., Daily, G.C., Gibbs, H.K., Helkowski, J.H., Holloway, T., Howard, E.A., Kucharik, C.J., Monfreda, C., Patz, J.A., Prentice, C.I., Ramankutty, N., Snyder, P.K., 2005. Global consequences of land use. Science 309, 570574.

Gan, H., Zak, D.R., Hunter, M.D., 2014. Trophic stability of soil oribatid mites in the face of environmental change. Soil Biology and Biochemistry 68, 71-77.

Gannes, L.Z., Brien, D.M.O., Martinez, C., Jun, N., 2007. Stable isotopes in animal ecology: Assumptions, caveat, and a call for more laboratory experiments. Ecology 78, 1271-1276.

Gibbs, H.K., Ruesch, A.S., Achard, F., Clayton, M.K., Holmgren, P., Ramankutty, N., Foley, J.A., 2010. Tropical forests were the primary sources of new agricultural land in the 1980s and 1990s. Proceedings of the National Academy of Sciences of the USA 107, 16732-16737.

Gleixner, G., Danier, H.J., Werner, R.A., Schmidt, H.L., 1993. Correlations between the ${ }^{13} \mathrm{C}$ content of primary and secondary plant products in different cell compartments and that in decomposing Basidiomycetes. Plant Physiology 102, 1287-1290.

Guillaume, T., Damris, M., Kuzyakov, Y., 2015. Losses of soil carbon by converting tropical forest to plantations: Erosion and decomposition estimated by $\delta^{13} \mathrm{C}$. Global Change Biology 21, 3548-3560.

Halaj, J., Peck, R.W., Niwa, C.G., 2005. Trophic structure of a macroarthropod litter food web in managed coniferous forest stands: A stable isotope analysis with $\delta^{15} \mathrm{~N}$ and $\delta^{13} \mathrm{C}$. Pedobiologia 49, 109-118.

Hanna, C., Naughton, I., Boser, C., Holway, D., 2015. Testing the effects of ant invasions on non-ant arthropods with high-resolution taxonomic data. Ecological Applications 25, 1841-1850.

Heethoff, M., Scheu, S., 2016. Reliability of isotopic fractionation ( $\Delta 15 N, \Delta 13 C$ ) for the delimitation of trophic levels of oribatid mites: Diet strongly affects $\Delta 13 \mathrm{C}$ but not $\Delta 15 \mathrm{~N}$. Soil Biology and Biochemistry 101, 124-129.

Heidemann, K., Hennies, A., Schakowske, J., Blumenberg, L., Ruess, L., Scheu, S., Maraun, M., 2014. Freeliving nematodes as prey for higher trophic levels of forest soil food webs. Oikos 123, 1199-1211.

Heidemann, K., Scheu, S., Ruess, L., Maraun, M., 2011. Molecular detection of nematode predation and scavenging in oribatid mites: Laboratory and field experiments. Soil Biology and Biochemistry 43, 2229-2236.

Heino, J., 2014. Taxonomic surrogacy, numerical resolution and responses of stream macroinvertebrate communities to ecological gradients: Are the inferences transferable among regions? Ecological Indicators 36, 186-194.

Hirst, A.J., 2006. Influence of taxonomic resolution on multivariate analyses of arthropod and macroalgal reef assemblages. Marin Ecology Progress Series 324, 83-93. 
Hobbie, E.A., Werner, R.A., 2004. Bulk carbon isotope patterns in $C_{3}$ and $C_{4}$ plants: $A$ review and synthesis. New Phytologist 161, 371-385.

Hooper, D.U., Chapin, F., Ewel, J., Hector, A., Inchausti, P., Lavorel, S., Lawton, J., Lodge, D., Loreau, M., Naeem, S., Schmid, B., Setälä, H., Symstad, A., Vandermeer, J., Wardle, D.A., 2005. Effects of biodiversity on ecosystem functioning: a consensus of current knowledge. Ecological Monographs 10, 3-35.

Hothorn, T., Bretz, F., Westfall, P., 2008. Simultaneous inference in general parametric models. Biometrical Journal 50, 346-363.

Illig, J., Langel, R., Norton, R.A.., Scheu, S., Maraun, M., 2005. Where are the decomposers? Uncovering the soil food web of a tropical montane rain forest in southern Ecuador using stable isotopes $\left({ }^{15} \mathrm{~N}\right)$. Journal of Tropical Ecology 21, 589-593.

Kempson, D., Monte, L., Ghelardi, R., 1963. A new extractor for woodland litter. Pedobiologia 3, 1-21.

Klarner, B., Maraun, M., Scheu, S., 2013. Trophic diversity and niche partitioning in a species rich predator guild - Natural variations in stable isotope ratios $\left({ }^{13} \mathrm{C} /{ }^{12} \mathrm{C},{ }^{15} \mathrm{~N} /{ }^{14} \mathrm{~N}\right.$ ) of mesostigmatid mites (Acari, Mesostigmata) from Central European beech. Soil Biology and Biochemistry 57, 327-333.

Klarner, B., Winkelmann, H., Krashevska, V., Maraun, M., Widyastuti, R., Scheu, S., 2017. Trophic niches, diversity and community composition of invertebrate top predators (Chilopoda) as affected by conversion of tropical lowland rainforest in Sumatra (Indonesia). PLOS ONE 1-17.

Koh, L.P., Wilcove, D.S., 2008. Is oil palm agriculture really destroying tropical biodiversity? Conservation Letters 1, 60-64.

Krashevska, V., Sandmann, D., Marian, F., Maraun, M., Scheu, S., 2017. Leaf litter chemistry drives the structure and composition of soil testate amoeba communities in a tropical montane rainforest of the Ecuadorian Andes. Microbial Ecology 74, 681-690.

Kreipe, V., Corral-Hernández, E., Scheu, S., Schaefer, I., Maraun, M., 2015. Phylogeny and species delineation in European species of the genus Steganacarus (Acari, Oribatida) using mitochondrial and nuclear markers. Experimental and Applied Acarology 173-186.

Lagerlöf, J., Maribie, C., John, J.M., 2017. Trophic interactions among soil arthropods in contrasting landuse systems in Kenya, studied with stable isotopes. European Journal of Soil Biology 79, 31-39.

Langel, R., Dyckmans, J., 2014. Combined ${ }^{13} \mathrm{C}$ and ${ }^{15} \mathrm{~N}$ isotope analysis on small samples using a nearconventional elemental analyzer/isotope ratio mass spectrometer setup. Rapid Communications in Mass Spectrometry 28, 1019-1022.

Laumonier, Y., Uryu, Y., Stüwe, M., Budiman, A., Setiabudi, B., Hadian, O., 2010. Eco-floristic sectors and deforestation threats in Sumatra: Identifying new conservation area network priorities for ecosystembased land use planning. Biodiversity and Conservation 19, 1153-1174.

Lavelle, P., Bignell, D., Lepage, M., Wolters, W., Roger, P., Ineson, P., Heal, O.W., Dhillion, S., 1997. Soil function in a changing world: The role of invertebrate ecosystem engineers. European Journal of Soil Biology 33, 159-193.

Lavelle, P., Decaëns, T., Aubert, M., Barot, S., Blouin, M., Bureau, F., Margerie, P., Mora, P., Rossi, J.P., 2006. Soil invertebrates and ecosystem services. European Journal of Soil Biology 42. 
Maaß, S., Maraun, M., Scheu, S., Rillig, M.C., Caruso, T., 2015. Environmental filtering vs. resource-based niche partitioning in diverse soil animal assemblages. Soil Biology and Biochemistry 85, 145-152.

Maraun, M., Erdmann, G., Fischer, B.M., Pollierer, M.M., Norton, R.A., Schneider, K., Scheu, S., 2011. Stable isotopes revisited: Their use and limits for oribatid mite trophic ecology. Soil Biology and Biochemistry 43, 877-882.

Maraun, M., Schatz, H., Scheu, S., 2007. Awesome or ordinary? Global diversity patterns of oribatid mites. Ecography 30, 209-216.

Maraun, M., Scheu, S., 2000. The structure of oribatid mite communities (Acari, Oribatida): Patterns, mechanisms and implications for future research. Source: Ecography 23, 374-383.

Margono, B.A., Potapov, P. V., Turubanova, S., Stolle, F., Hansen, M.C., 2014. Primary forest cover loss in indonesia over 2000-2012. Nature Climate Change 4, 730-735.

Marian, F., Sandmann, D., Krashevska, V., Maraun, M., Scheu, S., 2017. Leaf and root litter decomposition is discontinued at high altitude tropical montane rainforests contributing to carbon sequestration. Ecology and Evolution 7, 6432-6443.

Martin, A., Balesdent, J., Mariotti, A., 1992. Earthworm diet related to soil organic matter dynamics through ${ }^{13} \mathrm{C}$ measurments. Oecologia 91, 23-29.

McCutchan, J.H., Lewis, W.M., Kendall, C., McGrath, C.C., 2003. Variation in trophic shift for stable isotope ratios of carbon, nitrogen, and sulfur. Oikos 102, 378-390.

Meijide, A., Badu, C.S., Moyano, F., Tiralla, N., Gunawan, D., Knohl, A., 2018. Impact of forest conversion to oil palm and rubber plantations on microclimate and the role of the 2015 ENSO event. Agricultural and Forest Meteorology 252, 208-2019.

Miettinen, J., Shi, C., Liew, S.C., 2011. Deforestation rates in insular Southeast Asia between 2000 and 2010. Global Change Biology 17, 2261-2270.

Minor, M.A., Ermilov, S.G., Tiunov, A. V., 2017. Taxonomic resolution and functional traits in the analysis of tropical oribatid mite assemblages. Experimental and Applied Acarology 73, 365-381.

Myers, N., Mittermeier, R.A., Mittermeier, C.G., da Fonseca, G.A., Kent, J., 2000. Biodiversity hotspots for conservation priorities. Nature 403, 853-8.

Newbold, T., Hudson, L.N., Hill, S.L.L., Contu, S., Lysenko, I., Senior, R. a., Börger, L., Bennett, D.J., Choimes, A., Collen, B., Day, J., De Palma, A., Díaz, S., Echeverria-Londoño, S., Edgar, M.J., Feldman, A., Garon, M., Harrison, M.L.K., Alhusseini, T., Ingram, D.J., Itescu, Y., Kattge, J., Kemp, V., Kirkpatrick, L., Kleyer, M., Correia, D.L.P., Martin, C.D., Meiri, S., Novosolov, M., Pan, Y., Phillips, H.R.P., Purves, D.W., Robinson, A., Simpson, J., Tuck, S.L., Weiher, E., White, H.J., Ewers, R.M., MacE, G.M., Scharlemann, J.P.W., Purvis, A., 2015. Global effects of land use on local terrestrial biodiversity. Nature 520, 45-50.

Norton, R.A., Behan-Pelletier, V.M., 1991. Calcium carbonate and calcium oxalate as cuticular hardening agents in oribatid mites (Acari: Oribatida). Canadian Journal of Zoology 69, 1504-1511.

Pachl, P., Domes, K., Schulz, G., Norton, R.A., Scheu, S., Schaefer, I., Maraun, M., 2012. Convergent evolution of defense mechanisms in oribatid mites (Acari, Oribatida) shows no "ghosts of predation past". Molecular Phylogenetics and Evolution 412-20. 
Perdomo, G., Evans, A., Maraun, M., Sunnucks, P., Thompson, R., 2012. Mouthpart morphology and trophic position of microarthropods from soils and mosses are strongly correlated. Soil Biology and Biochemistry 53, 56-63.

Pinheiro, J., Bates, D., DebRoy, S., Sarkar, D., 2007. Linear and nonlinear mixed effects models. R Package Version 3, 1-89.

Pollierer, M.M., Langel, R., Scheu, S., Maraun, M., 2009. Compartmentalization of the soil animal food web as indicated by dual analysis of stable isotope ratios $\left({ }^{15} \mathrm{~N} /{ }^{14} \mathrm{~N}\right.$ and $\left.{ }^{13} \mathrm{C} /{ }^{12} \mathrm{C}\right)$. Soil Biology and Biochemistry 41, 1221-1226.

Post, D.M., 2002. Using stable isotopes to estimate trophic position: Models, methos, and assumptions. Ecology 83, 703-718.

Potapov, A.M., Tiunov, A. V., Scheu, S., 2019. Uncovering trophic positions and food resources of soil animlas using bulk natural stable isotope composition. Biological Reviews 94, 37-59.

Powers, J.S., Montgomery, R. a., Adair, E.C., Brearley, F.Q., Dewalt, S.J., Castanho, C.T., Chave, J., Deinert, E., Ganzhorn, J.U., Gilbert, M.E., González-Iturbe, J.A., Bunyavejchewin, S., Grau, H.R., Harms, K.E., Hiremath, A., Iriarte-Vivar, S., Manzane, E., De Oliveira, A. a., Poorter, L., Ramanamanjato, J.B., Salk, C., Varela, A., Weiblen, G.D., Lerdau, M.T., 2009. Decomposition in tropical forests: A pan-tropical study of the effects of litter type, litter placement and mesofaunal exclusion across a precipitation gradient. Journal of Ecology 97, 801-811.

R Core Team, 2018. R: A language and environment for statistical computing. R Foundation for Statistical Computing,.

Riera, P., 2010. Trophic plasticity of the gastropod Hydrobia ulvae within an intertidal bay (Roscoff, France): A stable isotope evidence. Journal of Sea Research 63, 78-83.

Rockett, C.L., 1980. Nematode predation by oribatid mites (Acari: Oribatida). International Journal of Acarology 6, 219-224.

Rosumek, F.B., Blüthgen, N., Brückner, A., Menzel, F., Gebauer, G., Heethoff, M., 2018. Unveiling community patterns and trophic niches of tropical and temperate ants using an integrative framework of field data, stable isotopes and fatty acids. PeerJ 6.

Scheu, S., Falca, M., 2000. The soil food web of two beech forests (Fagus sylvatica) of contrasting humus type: Stable isotope analysis of a macro- and a mesofauna-dominated community. Oecologia 123, 285-296.

Scheu, S., Illig, J., Eissfeller, V., Krashevska, V., Sandmann, D., Maraun, M., 2008. The soil fauna of a tropical mountain rainforest in southern Ecuador: Structure and functioning, The tropical mountain forest. Patterns and Processes in a Biodiversity Hotspots. Biodiversity and Ecology Series 2. Göttingen, Universitätsverlag.

Schneider, K., Migge, S., Norton, R.A., Scheu, S., Langel, R., Reineking, A., Maraun, M., 2004. Trophic niche differentiation in soil microarthropods (Oribatida, Acari): Evidence from stable isotope $\operatorname{ratios}\left({ }^{15} \mathrm{~N} /{ }^{14} \mathrm{~N}\right)$. Soil Biology and Biochemistry 36, 1769-1774.

Sodhi, N.S., Posa, M.R.C., Lee, T.M., Bickford, D., Koh, L.P., Brook, B.W., 2010. The state and conservation of Southeast Asian biodiversity. Biodiversity and Conservation 19, 317-328. 
Somerfield, P.J., Clarke, K.R., 1995. Taxonomic levels, in marine community studies, revisited. Marine Ecology Progress Series 127, 113-119.

Subías, L.S., Shtanchaeva, U.Y., Arillo, A., 2018. Listado de los ácaros oribátidos (Acariformes, Oribatida) de las diferentes regiones biogeográficas del mundo (6 actzalización) 1939, 1-874.

Swift, M.J., Heal, O.W., Anderson, J.M., 1979. Decomposition in terrestrial ecosystems, Decomposition in terrestrial ecosystems. Univ of California Press.

Teuscher, M., Gérard, A., Brose, U., Buchori, D., Clough, Y., Ehbrecht, M., Hölscher, D., Irawan, B., Sundawati, L., Wollni, M., Kreft, H., 2016. Experimental biodiversity enrichment in oil-palmdominated landscapes in Indonesia. Frontiers in Plant Science 07, 1-15.

Tiunov, A. V., 2007. Stable isotopes of carbon and nitrogen in soil ecological studies. Biology Bulletin 34, 395-407.

Vanderklift, M. a., Ponsard, S., 2003. Sources of variation in consumer-diet $\delta^{15} \mathrm{~N}$ enrichment: A metaanalysis. Oecologia 136, 169-182.

Wada, E., Mizutani, H., Minagawa, M., 1991. The use of stable isotopes for food web analysis. Critical Reviews in Food Science and Nutrition 30(4), 361-371.

Walter, D.E., Proctor, H.C., 2013. Mites : Ecology, Evolution \& Behaviour.

Whalen, J., Sampedro, L., 2010. Soil ecology and management, CAB International. CABI.

Wilcove, D.S., Giam, X., Edwards, D.P., Fisher, B., Koh, L.P., 2013. Navjot's nightmare revisited: Logging, agriculture, and biodiversity in Southeast Asia. Trends in Ecology and Evolution 28, 531-540. 


\section{Appendix}

Bischeloribates mahunkai (44 measurements)

Plonaphacaruskugohi (19 measurements)

Protoribates paracapucinus (54 measurements)

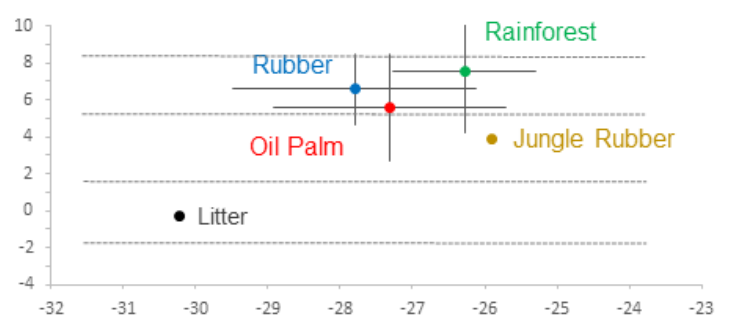

Predator

Secondary Decomposer

Primary Decomposer

Predator

Secondary Decomposer Primary Decomposer

Predator

Secondary Decomposer

Primary Decomposer

Figure S1: Stable isotope $\left(\delta^{13} \mathrm{C}\right.$ and $\left.\delta^{15} \mathrm{~N}\right)$ values of oribatid mite species [Bischeloribates mahunkai Subías, 2010, Plonaphacarus kugohi (Aoki, 1959) and Protoribates paracapucinus (Mahunka, 1988)] in the four land-use systems studied (rainforest, jungle rubber, rubber and oil palm plantations). Means with standard deviation; numbers of measurements per species are given in brackets. The average stable isotope value of litter used for calibration (see Methods) is given as reference. Dashed horizontal lines reflect boundaries of trophic levels (primary decomposers, secondary decomposers and predators; see Methods). For statistical analysis see text. 


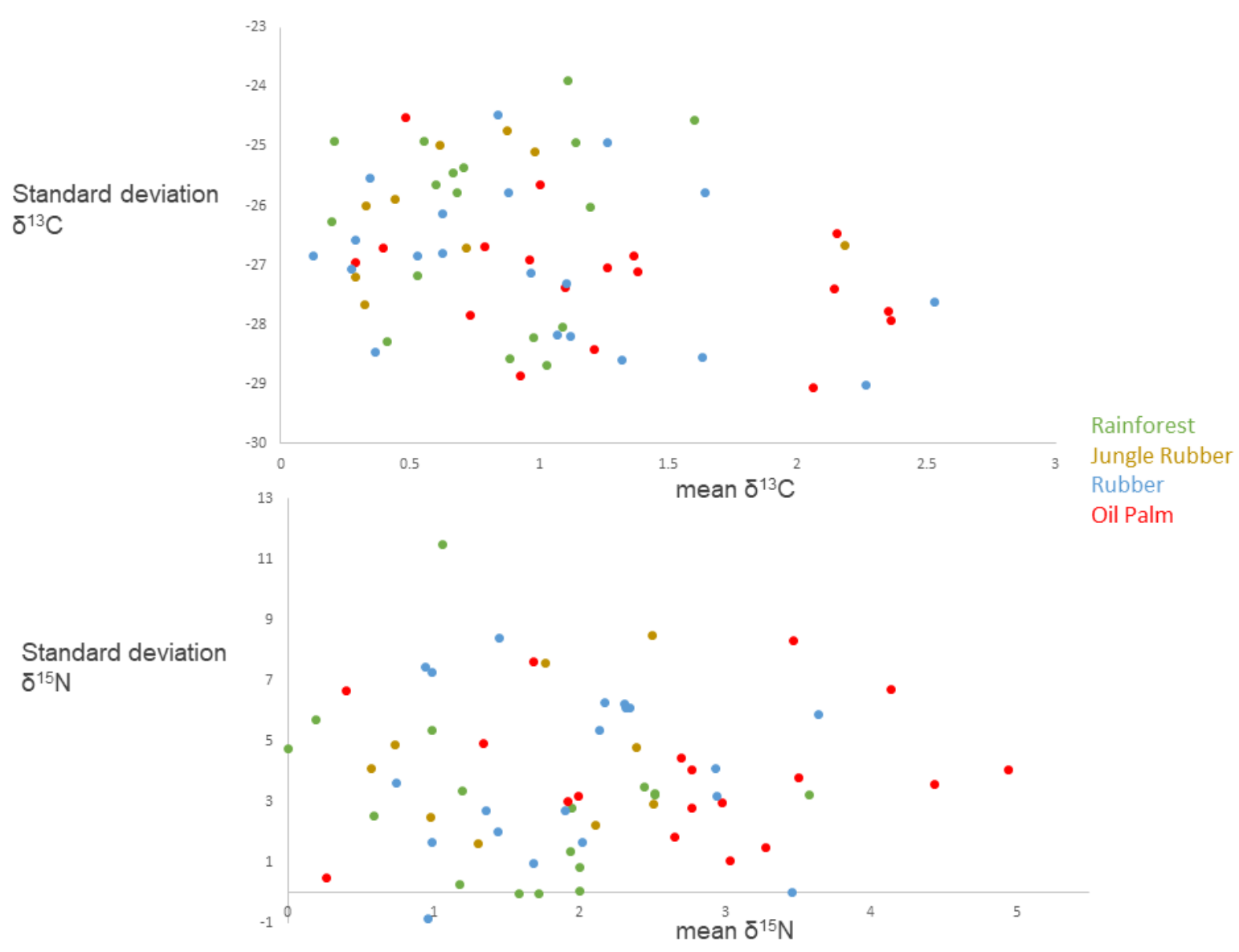

Figure S1: Plotwise standard deviation of mean stable isotope $\left(\delta^{13} \mathrm{C}\right.$ and $\left.\delta^{15} \mathrm{~N}\right)$ values of oribatid mite species in the four land-use systems studied (rainforest, jungle rubber, rubber and oil palm plantations) plotted against their stable isotope values $\left(\delta^{13} \mathrm{C}\right.$ and $\left.\delta^{15} \mathrm{~N}\right)$. For details see Table $\mathrm{S} 2$ in Appendix.

Table S1: Absolute and calibrated (see methods) stable isotope values of oribatid mite individuals studied. Species ID in Ecotaxonomy database (http://ecotaxonomy.org/), species name, author, landscape, land-use system, absolute values of $\delta^{15} \mathrm{~N}$ and $\delta^{13} \mathrm{C}$ values, and calibrated $\delta^{15} \mathrm{~N}$ and $\delta^{13} \mathrm{C}$ values (all values are rounded to two decimal places). Mean $\delta^{15} \mathrm{~N}$ and $\delta^{13} \mathrm{C}$ values of litter used for calibration of -0.24 and $-30.23 \%$, respectively.

\begin{tabular}{|c|c|c|c|c|c|c|c|c|}
\hline \multirow{2}{*}{$\begin{array}{c}\text { species } \\
\text { ID }\end{array}$} & \multirow[t]{2}{*}{ species } & \multirow[t]{2}{*}{ author } & \multirow[t]{2}{*}{ landscape } & \multirow{2}{*}{$\begin{array}{l}\text { land-use } \\
\text { system }\end{array}$} & \multicolumn{2}{|c|}{ absolute } & \multicolumn{2}{|c|}{ calibrated } \\
\hline & & & & & $\delta 15 N$ & $\delta 13 C$ & $\delta 15 N$ & $\delta 13 C$ \\
\hline \multirow[t]{2}{*}{405450} & Bischeloribates mahunkai & $\begin{array}{c}\text { Subías, } \\
2010\end{array}$ & Bukit Duabelas & jungle rubber & 1.97 & -26.69 & 3.90 & -25.90 \\
\hline & & & & oil palm & 1.68 & -25.86 & 0.60 & -25.86 \\
\hline
\end{tabular}




\begin{tabular}{|c|c|c|c|c|c|c|c|}
\hline & & & & 3.86 & -26.23 & 2.77 & -26.22 \\
\hline & & & & 4.27 & -28.71 & 3.19 & -28.71 \\
\hline & & & & 4.72 & -27.31 & 3.64 & -27.31 \\
\hline & & & & 5.47 & -26.96 & 4.39 & -26.96 \\
\hline & & & & 8.29 & -29.06 & 7.20 & -29.06 \\
\hline & & & & 10.37 & -27.37 & 9.29 & -27.36 \\
\hline & & & \multirow[t]{3}{*}{ rainforest } & 3.68 & -27.43 & 4.10 & -26.37 \\
\hline & & & & 4.67 & -27.62 & 4.41 & -26.05 \\
\hline & & & & 6.64 & -26.21 & 6.38 & -24.63 \\
\hline & & & \multirow[t]{13}{*}{ rubber } & 1.86 & -25.67 & 2.29 & -26.34 \\
\hline & & & & 1.75 & -25.41 & 3.52 & -25.93 \\
\hline & & & & 2.80 & -26.42 & 4.58 & -26.95 \\
\hline & & & & 3.91 & -27.45 & 5.58 & -27.92 \\
\hline & & & & 6.01 & -28.34 & 6.43 & -29.01 \\
\hline & & & & 5.05 & -26.03 & 6.72 & -26.50 \\
\hline & & & & 6.84 & -27.79 & 7.26 & -28.46 \\
\hline & & & & 5.74 & -26.66 & 7.52 & -27.19 \\
\hline & & & & 6.11 & -25.61 & 7.79 & -26.09 \\
\hline & & & & 6.38 & -26.04 & 8.06 & -26.52 \\
\hline & & & & 6.51 & -26.39 & 8.18 & -26.87 \\
\hline & & & & 8.00 & -28.17 & 8.43 & -28.85 \\
\hline & & & & 7.54 & -26.72 & 9.32 & -27.24 \\
\hline & & \multirow[t]{20}{*}{ Harapan } & \multirow[t]{7}{*}{ oil palm } & 3.44 & -25.98 & 1.56 & -26.63 \\
\hline & & & & 6.93 & -27.15 & 5.69 & -28.55 \\
\hline & & & & 6.96 & -26.67 & 5.72 & -28.06 \\
\hline & & & & 8.57 & -25.57 & 7.33 & -26.97 \\
\hline & & & & 9.18 & -26.57 & 7.94 & -27.96 \\
\hline & & & & 9.93 & -28.36 & 8.69 & -29.76 \\
\hline & & & & 11.76 & -21.56 & 10.51 & -22.96 \\
\hline & & & \multirow[t]{2}{*}{ rainforest } & 10.89 & -27.22 & 10.45 & -26.64 \\
\hline & & & & 13.00 & -28.27 & 12.56 & -27.70 \\
\hline & & & \multirow[t]{11}{*}{ rubber } & 6.48 & -30.93 & 4.32 & -31.91 \\
\hline & & & & 6.90 & -29.64 & 4.74 & -30.62 \\
\hline & & & & 7.08 & -27.00 & 4.92 & -27.98 \\
\hline & & & & 7.17 & -25.97 & 5.01 & -26.95 \\
\hline & & & & 7.03 & -26.71 & 5.72 & -28.12 \\
\hline & & & & 7.98 & -24.16 & 5.82 & -25.14 \\
\hline & & & & 5.07 & -25.10 & 6.12 & -26.04 \\
\hline & & & & 7.04 & -26.23 & 8.08 & -27.16 \\
\hline & & & & 7.10 & -27.79 & 8.15 & -28.73 \\
\hline & & & & 11.06 & -30.14 & 8.90 & -31.12 \\
\hline & & & & 12.46 & -28.40 & 10.30 & -29.38 \\
\hline \multirow[t]{4}{*}{405729} & \multirow[t]{4}{*}{ Plonaphacarus kugohi } & \multirow[t]{4}{*}{ Bukit Duabelas } & \multirow[t]{2}{*}{ jungle rubber } & -1.42 & -23.83 & 1.07 & -24.19 \\
\hline & & & & -0.04 & -24.17 & 2.45 & -24.52 \\
\hline & & & \multirow[t]{2}{*}{ oil palm } & 1.66 & -28.09 & 0.15 & -28.43 \\
\hline & & & & 5.60 & -27.71 & 4.09 & -28.05 \\
\hline
\end{tabular}




\begin{tabular}{|c|c|c|c|c|c|c|c|c|}
\hline & & & & rainforest & -2.34 & -26.70 & -3.10 & -25.26 \\
\hline & & & & rubber & 0.59 & -26.03 & 1.02 & -26.71 \\
\hline & & & & & 2.40 & -23.41 & 2.83 & -24.08 \\
\hline & & & & & 1.82 & -23.25 & 3.59 & -23.77 \\
\hline & & & & & 3.90 & -23.30 & 4.33 & -23.97 \\
\hline & & & & & 4.37 & -21.55 & 6.04 & -22.03 \\
\hline & & & Harapan & oil palm & 1.75 & -24.54 & 0.51 & -25.93 \\
\hline & & & & rainforest & 3.61 & -24.62 & 3.17 & -24.05 \\
\hline & & & & rubber & -1.26 & -26.42 & -3.42 & -27.40 \\
\hline & & & & & 0.41 & -22.25 & -0.90 & -23.66 \\
\hline & & & & & -0.52 & -25.46 & -0.36 & -26.89 \\
\hline & & & & & 1.62 & -22.75 & 0.31 & -24.15 \\
\hline & & & & & 2.07 & -22.76 & 0.76 & -24.17 \\
\hline & & & & & 5.65 & -23.14 & 3.49 & -24.12 \\
\hline & & & & & 4.99 & -24.46 & 3.68 & -25.87 \\
\hline & & & & & 4.90 & -32.58 & 5.06 & -34.01 \\
\hline 405671 & Protoribates paracapucinus & $\begin{array}{c}\text { (Mahunka, } \\
\text { 1988) }\end{array}$ & Bukit Duabelas & jungle rubber & -0.78 & -27.14 & 1.14 & -26.35 \\
\hline & & & & & 0.13 & -26.76 & 1.54 & -25.59 \\
\hline & & & & & 1.05 & -26.30 & 2.97 & -25.52 \\
\hline & & & & & 2.09 & -25.01 & 3.50 & -23.85 \\
\hline & & & & & 3.83 & -26.20 & 5.75 & -25.41 \\
\hline & & & & & 4.54 & -24.22 & 6.47 & -23.44 \\
\hline & & & & & 4.76 & -26.02 & 7.25 & -26.37 \\
\hline & & & & & 5.71 & -25.45 & 7.63 & -24.66 \\
\hline & & & & oil palm & 0.75 & -26.53 & -0.33 & -26.52 \\
\hline & & & & & 4.32 & -32.45 & 3.24 & -32.45 \\
\hline & & & & & 4.57 & -26.20 & 3.49 & -26.20 \\
\hline & & & & & 4.13 & -25.75 & 3.60 & -26.40 \\
\hline & & & & & 4.96 & -26.85 & 3.88 & -26.85 \\
\hline & & & & & 4.95 & -23.57 & 4.41 & -24.22 \\
\hline & & & & & 4.85 & -26.58 & 4.80 & -24.67 \\
\hline & & & & & 6.87 & -26.83 & 5.79 & -26.82 \\
\hline & & & & & 7.29 & -25.64 & 6.76 & -26.29 \\
\hline & & & & rainforest & -1.06 & -26.53 & -1.32 & -24.96 \\
\hline & & & & & -0.54 & -26.48 & -1.25 & -28.00 \\
\hline & & & & & 2.79 & -28.05 & 2.54 & -26.48 \\
\hline & & & & & 4.89 & -24.53 & 4.63 & -22.95 \\
\hline & & & & & 5.48 & -26.93 & 5.23 & -25.36 \\
\hline & & & & & 5.60 & -26.45 & 5.34 & -24.88 \\
\hline & & & & & 5.10 & -26.16 & 5.52 & -25.10 \\
\hline & & & & & 5.48 & -25.76 & 5.90 & -24.70 \\
\hline & & & & rubber & -1.74 & -25.42 & -1.32 & -26.09 \\
\hline & & & & & 1.48 & -25.86 & 2.79 & -26.08 \\
\hline & & & & & 2.44 & -25.04 & 3.74 & -25.26 \\
\hline & & & & & 5.25 & -26.22 & 6.92 & -26.69 \\
\hline
\end{tabular}




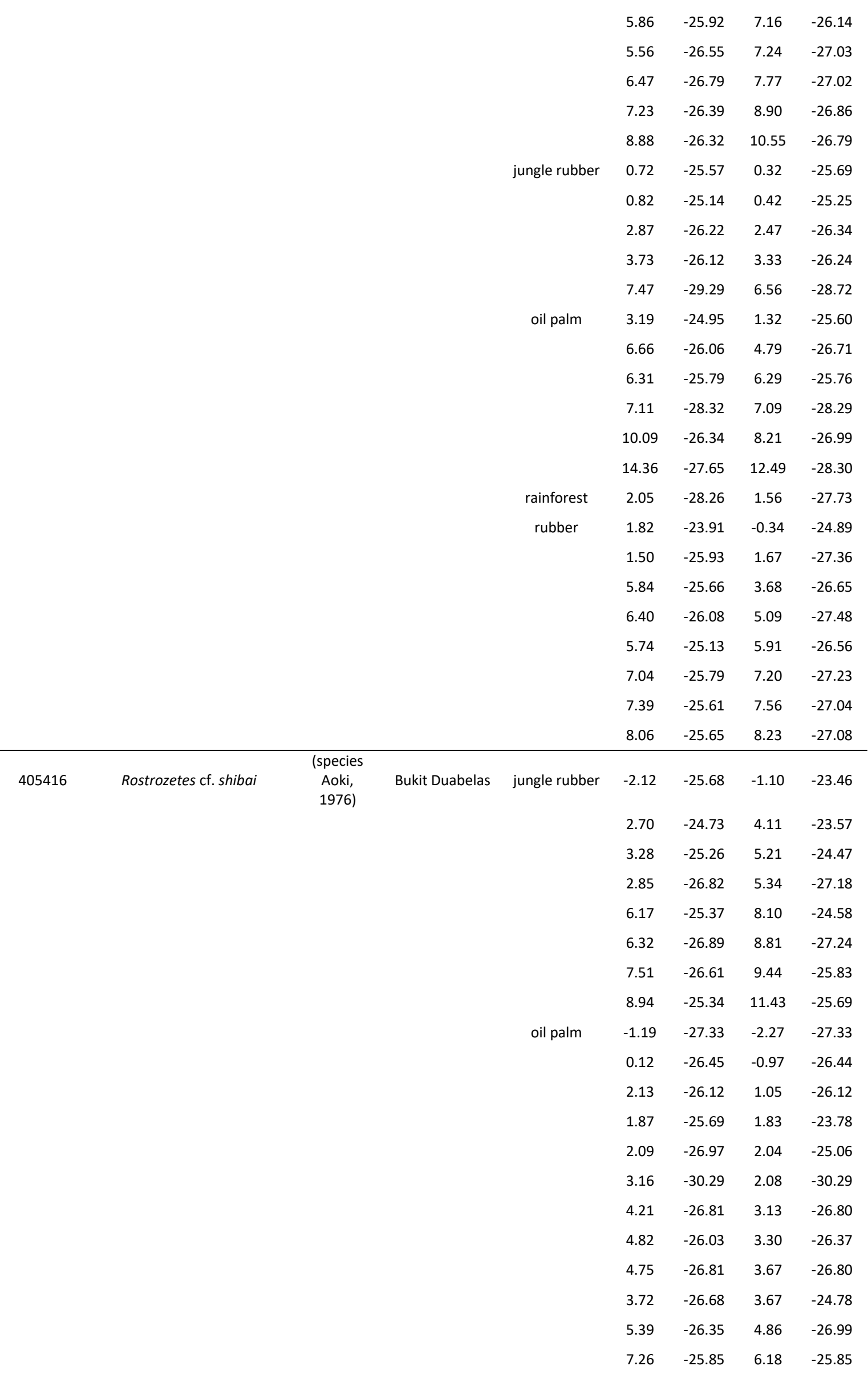




\begin{tabular}{|c|c|c|c|c|c|}
\hline & & 8.74 & -26.30 & 8.69 & -24.40 \\
\hline & & 12.31 & -30.47 & 11.78 & -31.12 \\
\hline & rainforest & -0.53 & -26.48 & -1.29 & -25.04 \\
\hline & & -0.98 & -24.72 & -1.24 & -23.15 \\
\hline & & -0.77 & -26.60 & -0.34 & -25.54 \\
\hline & & 1.40 & -29.73 & 1.14 & -28.16 \\
\hline & & 0.81 & -27.16 & 1.23 & -26.10 \\
\hline & & 2.90 & -25.66 & 2.13 & -24.22 \\
\hline & & 2.92 & -26.11 & 2.66 & -24.54 \\
\hline & & 3.28 & -24.85 & 3.02 & -23.28 \\
\hline & & 3.33 & -24.27 & 3.07 & -22.70 \\
\hline & & 4.02 & -23.82 & 3.26 & -22.38 \\
\hline & & 3.20 & -26.35 & 3.62 & -25.29 \\
\hline & & 4.44 & -26.59 & 4.18 & -25.01 \\
\hline & & 4.62 & -26.55 & 4.36 & -24.98 \\
\hline & & 5.45 & -26.35 & 4.74 & -27.87 \\
\hline & & 5.46 & -27.17 & 4.75 & -28.69 \\
\hline & & 4.87 & -25.94 & 5.29 & -24.88 \\
\hline & & 5.68 & -26.11 & 5.42 & -24.54 \\
\hline & & 6.05 & -29.33 & 6.47 & -28.28 \\
\hline & rubber & -3.17 & -29.85 & -1.87 & -30.07 \\
\hline & & -2.54 & -29.92 & -0.76 & -30.45 \\
\hline & & 2.24 & -28.19 & 4.02 & -28.71 \\
\hline & & 4.52 & -25.94 & 6.29 & -26.46 \\
\hline Harapan & jungle rubber & 3.53 & -25.70 & 4.25 & -25.67 \\
\hline & & 3.79 & -25.90 & 4.51 & -25.87 \\
\hline & & 5.20 & -26.47 & 5.92 & -26.45 \\
\hline & oil palm & 0.50 & -25.79 & -0.28 & -27.06 \\
\hline & & 1.36 & -26.46 & 0.11 & -27.85 \\
\hline & & 0.89 & -27.13 & 0.11 & -28.40 \\
\hline & & 2.38 & -25.87 & 0.50 & -26.52 \\
\hline & & 1.91 & -28.68 & 0.67 & -30.08 \\
\hline & & 1.91 & -25.86 & 0.67 & -27.26 \\
\hline & & 2.83 & -24.83 & 0.96 & -25.48 \\
\hline & & 4.31 & -27.23 & 3.54 & -28.50 \\
\hline & & 4.34 & -25.55 & 3.56 & -26.82 \\
\hline & & 5.81 & -27.25 & 3.94 & -27.90 \\
\hline & & 6.32 & -25.82 & 4.44 & -26.47 \\
\hline & & 7.13 & -26.35 & 5.26 & -27.00 \\
\hline & & 14.17 & -27.11 & 13.40 & -28.38 \\
\hline & rainforest & 0.44 & -26.19 & -0.09 & -25.38 \\
\hline & & 2.46 & -26.97 & 1.96 & -26.45 \\
\hline & & 2.61 & -25.62 & 2.17 & -25.04 \\
\hline & & 3.20 & -25.52 & 2.67 & -24.71 \\
\hline & & 3.18 & -26.15 & 2.91 & -25.16 \\
\hline & & 3.63 & -26.58 & 3.14 & -26.06 \\
\hline
\end{tabular}




\begin{tabular}{|c|c|c|c|c|c|c|c|c|}
\hline & & & & & 4.99 & -26.81 & 4.55 & -26.24 \\
\hline & & & & \multirow{8}{*}{ rubber } & 5.65 & -26.26 & 5.11 & -25.45 \\
\hline & & & & & 6.81 & -24.90 & 6.28 & -24.08 \\
\hline & & & & & 0.45 & -25.94 & 0.61 & -27.37 \\
\hline & & & & & 2.02 & -24.86 & 0.71 & -26.27 \\
\hline & & & & & 2.11 & -28.99 & 2.28 & -30.43 \\
\hline & & & & & 3.98 & -25.44 & 2.67 & -26.85 \\
\hline & & & & & 2.69 & -24.78 & 3.74 & -25.72 \\
\hline & & & & & 5.05 & -26.55 & 5.21 & -27.98 \\
\hline \multirow[t]{13}{*}{405478} & Rostrozetes sp. 1 & & Bukit Duabelas & jungle rubber & 1.45 & -27.95 & 2.47 & -25.74 \\
\hline & & & & & 1.56 & -27.35 & 3.49 & -26.56 \\
\hline & & & & & 1.06 & -26.54 & 3.55 & -26.90 \\
\hline & & & & & 2.83 & -26.85 & 4.24 & -25.68 \\
\hline & & & & & 2.20 & -27.12 & 4.69 & -27.47 \\
\hline & & & & oil palm & 4.18 & -29.57 & 3.10 & -29.57 \\
\hline & & & & & 7.56 & -28.80 & 6.05 & -29.14 \\
\hline & & & & jungle rubber & 7.67 & -27.03 & 8.39 & -27.00 \\
\hline & & & & rainforest & 1.62 & -28.47 & 1.18 & -27.89 \\
\hline & & & & & 2.33 & -27.30 & 1.89 & -26.72 \\
\hline & & & & & 3.31 & -27.59 & 2.87 & -27.01 \\
\hline & & & & rubber & 7.03 & -27.33 & 8.34 & -27.55 \\
\hline & & & Harapan & rubber & 5.38 & -25.82 & 4.07 & -27.23 \\
\hline \multirow[t]{23}{*}{405449} & Scheloribates praeincisus & $\begin{array}{c}\text { (Berlese, } \\
\text { 1910) }\end{array}$ & Bukit Duabelas & jungle rubber & -2.53 & -26.90 & -0.04 & -27.25 \\
\hline & & & & & 0.33 & -27.30 & 2.82 & -27.65 \\
\hline & & & & & 2.76 & -27.31 & 4.17 & -26.15 \\
\hline & & & & & 3.60 & -27.69 & 6.09 & -28.05 \\
\hline & & & & oil palm & -1.89 & -25.56 & -2.97 & -25.56 \\
\hline & & & & & -1.83 & -27.84 & -2.91 & -27.84 \\
\hline & & & & & -0.86 & -28.79 & -0.91 & -26.88 \\
\hline & & & & & 1.18 & -29.00 & -0.34 & -29.34 \\
\hline & & & & & 0.79 & -28.85 & -0.29 & -28.85 \\
\hline & & & & & 1.32 & -25.11 & 0.23 & -25.11 \\
\hline & & & & & 2.32 & -29.83 & 0.81 & -30.17 \\
\hline & & & & & 2.32 & -25.75 & 1.23 & -25.75 \\
\hline & & & & & 3.20 & -29.27 & 1.68 & -29.62 \\
\hline & & & & & 3.59 & -27.26 & 2.07 & -27.61 \\
\hline & & & & & 3.93 & -29.01 & 2.84 & -29.00 \\
\hline & & & & & 4.53 & -28.97 & 3.45 & -28.97 \\
\hline & & & & & 3.71 & -28.96 & 3.66 & -27.06 \\
\hline & & & & & 5.10 & -23.05 & 4.02 & -23.04 \\
\hline & & & & & 6.82 & -27.63 & 5.30 & -27.97 \\
\hline & & & & & 5.76 & -28.05 & 5.71 & -26.14 \\
\hline & & & & & 8.93 & -23.92 & 7.85 & -23.92 \\
\hline & & & & & 9.93 & -28.05 & 8.42 & -28.39 \\
\hline & & & & rainforest & -9.52 & -26.49 & -9.78 & -24.92 \\
\hline
\end{tabular}




\begin{tabular}{|c|c|c|c|c|c|}
\hline & & -1.41 & -27.96 & -2.17 & -26.52 \\
\hline & & -2.12 & -26.06 & -1.69 & -25.00 \\
\hline & & -1.24 & -30.27 & -1.50 & -28.70 \\
\hline & & -1.18 & -30.60 & -1.44 & -29.03 \\
\hline & & -1.10 & -30.82 & -1.36 & -29.25 \\
\hline & & -0.98 & -29.64 & -1.24 & -28.06 \\
\hline & & -0.46 & -27.36 & -1.23 & -25.92 \\
\hline & & -0.66 & -28.84 & -0.92 & -27.27 \\
\hline & & -0.42 & -28.17 & -0.68 & -26.60 \\
\hline & & -0.24 & -30.73 & -0.50 & -29.16 \\
\hline & & 1.38 & -28.14 & 0.61 & -26.70 \\
\hline & & 1.74 & -28.43 & 1.48 & -26.86 \\
\hline & & 2.75 & -26.32 & 1.98 & -24.88 \\
\hline & & 2.24 & -27.99 & 1.98 & -26.42 \\
\hline & & 3.19 & -26.82 & 2.42 & -25.38 \\
\hline & & 4.20 & -26.60 & 3.43 & -25.16 \\
\hline & & 4.42 & -27.42 & 4.84 & -26.36 \\
\hline & & 5.24 & -30.60 & 4.98 & -29.03 \\
\hline & & 6.20 & -25.98 & 6.63 & -24.92 \\
\hline & rubber & -1.46 & -25.47 & 0.22 & -25.94 \\
\hline & & -1.45 & -26.74 & 0.33 & -27.26 \\
\hline & & 0.46 & -24.63 & 2.14 & -25.10 \\
\hline & & 1.35 & -26.87 & 2.65 & -27.09 \\
\hline & & 2.07 & -25.07 & 3.74 & -25.54 \\
\hline & & 2.56 & -27.54 & 3.87 & -27.76 \\
\hline & & 3.13 & -29.50 & 4.44 & -29.72 \\
\hline & & 3.29 & -28.12 & 5.06 & -28.64 \\
\hline & & 6.62 & -25.94 & 8.39 & -26.46 \\
\hline & & 7.99 & -25.62 & 9.77 & -26.14 \\
\hline Harapan & jungle rubber & -1.30 & -29.32 & -2.21 & -28.75 \\
\hline & & -1.66 & -26.63 & -0.93 & -26.60 \\
\hline & & -0.04 & -28.86 & 0.19 & -29.39 \\
\hline & & -0.02 & -22.01 & 0.71 & -21.98 \\
\hline & & 0.85 & -27.87 & 1.58 & -27.84 \\
\hline & & 2.05 & -26.97 & 2.77 & -26.95 \\
\hline & & 3.16 & -28.39 & 3.88 & -28.36 \\
\hline & & 4.82 & -28.18 & 5.54 & -28.15 \\
\hline & oil palm & -2.70 & -25.41 & -4.57 & -26.06 \\
\hline & & -0.09 & -25.96 & -0.86 & -27.23 \\
\hline & & 1.44 & -23.86 & -0.44 & -24.51 \\
\hline & & 1.04 & -26.92 & 1.02 & -26.89 \\
\hline & & 2.38 & -27.14 & 1.13 & -28.54 \\
\hline & & 3.07 & -27.58 & 1.20 & -28.23 \\
\hline & & 2.79 & -29.04 & 1.55 & -30.44 \\
\hline & & 4.44 & -26.93 & 2.57 & -27.58 \\
\hline & & 4.53 & -27.70 & 2.66 & -28.35 \\
\hline
\end{tabular}




\begin{tabular}{|c|c|c|c|c|}
\hline & 6.97 & -25.57 & 5.10 & -26.22 \\
\hline & 8.77 & -25.39 & 8.00 & -26.66 \\
\hline & 10.01 & -23.36 & 8.77 & -24.76 \\
\hline rainforest & -6.15 & -29.49 & -6.69 & -28.67 \\
\hline & -1.71 & -29.42 & -2.24 & -28.60 \\
\hline & -1.75 & -29.92 & -2.19 & -29.34 \\
\hline & -1.38 & -28.41 & -1.87 & -27.89 \\
\hline & -1.30 & -28.31 & -1.79 & -27.78 \\
\hline & -0.89 & -30.20 & -1.42 & -29.39 \\
\hline & -0.29 & -30.57 & -0.83 & -29.75 \\
\hline & 0.56 & -27.76 & 0.11 & -27.18 \\
\hline & 0.71 & -30.67 & 0.21 & -30.14 \\
\hline & 0.89 & -28.15 & 0.36 & -27.33 \\
\hline & 0.92 & -28.79 & 0.48 & -28.22 \\
\hline & 1.33 & -28.29 & 0.89 & -27.72 \\
\hline & 1.56 & -29.59 & 1.03 & -28.78 \\
\hline & 1.50 & -30.43 & 1.06 & -29.86 \\
\hline & 1.81 & -30.33 & 1.36 & -29.75 \\
\hline & 1.98 & -27.93 & 1.49 & -27.41 \\
\hline & 2.37 & -28.40 & 1.88 & -27.87 \\
\hline & 3.51 & -28.36 & 2.98 & -27.55 \\
\hline rubber & -0.50 & -26.68 & -1.81 & -28.09 \\
\hline & -1.04 & -25.24 & -0.88 & -26.67 \\
\hline & 1.41 & -27.41 & 0.10 & -28.81 \\
\hline & 2.80 & -20.89 & 2.96 & -22.32 \\
\hline & 2.83 & -27.14 & 2.99 & -28.57 \\
\hline & 3.22 & -25.80 & 3.38 & -27.24 \\
\hline & 3.34 & -26.71 & 3.50 & -28.15 \\
\hline & 3.62 & -28.54 & 3.79 & -29.97 \\
\hline & 3.74 & -28.48 & 3.91 & -29.91 \\
\hline & 4.02 & -23.44 & 4.18 & -24.87 \\
\hline & 5.58 & -30.04 & 5.75 & -31.47 \\
\hline & 11.36 & -25.42 & 11.52 & -26.86 \\
\hline
\end{tabular}


Table S2: Standard deviation of mean stable isotope $(\delta 13 \mathrm{C}$ and $\delta 15 \mathrm{~N})$ values of oribatid mite species in the four land-use systems studied. Species ID in Ecotaxonomy database (http://ecotaxonomy.org/), species name, land-use system, plotID, replicate, standard deviation of $\delta^{13} \mathrm{C}$ and $\delta^{15} \mathrm{~N}$, mean stable isotope values of $\delta^{13} \mathrm{C}$ and $\delta^{15} \mathrm{~N}$.

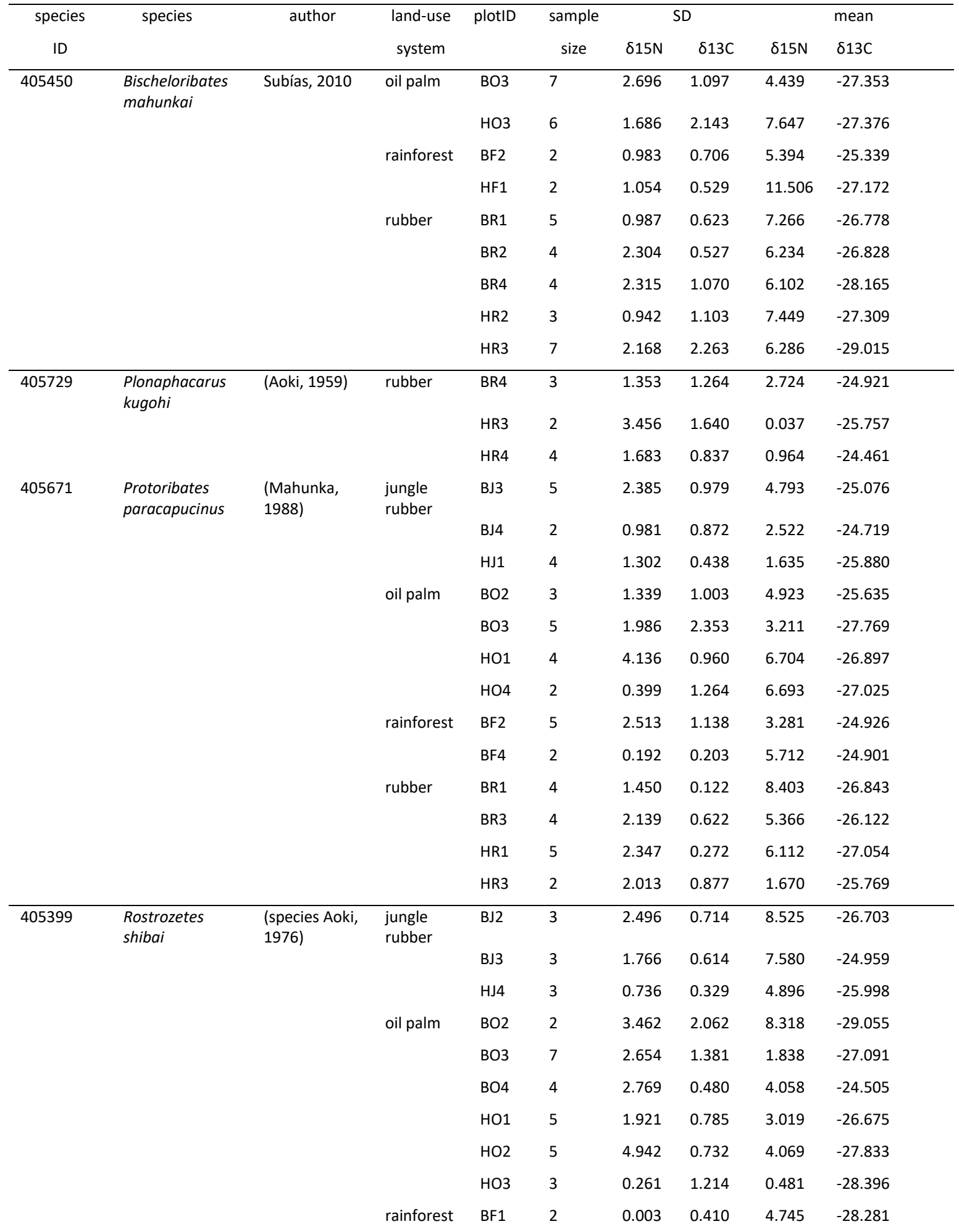




\begin{tabular}{|c|c|c|c|c|c|c|c|c|c|}
\hline & & & & BF2 & 8 & 1.949 & 1.598 & 2.825 & -24.543 \\
\hline & & & & BF3 & 3 & 1.934 & 1.111 & 1.365 & -23.881 \\
\hline & & & & BF4 & 5 & 2.517 & 1.197 & 3.256 & -26.016 \\
\hline & & & & HF1 & 2 & 1.190 & 0.596 & 3.359 & -25.639 \\
\hline & & & & HF3 & 4 & 2.443 & 0.554 & 3.495 & -24.904 \\
\hline & & & & HF4 & 2 & 0.588 & 0.194 & 2.553 & -26.252 \\
\hline & & & rubber & BR2 & 3 & 2.940 & 1.631 & 3.182 & -28.538 \\
\hline & & & & HR1 & 3 & 1.901 & 1.320 & 2.702 & -28.593 \\
\hline & & & & HR4 & 2 & 0.982 & 0.289 & 1.692 & -26.557 \\
\hline 405478 & $\begin{array}{l}\text { Rostrozetes } s p . \\
1\end{array}$ & $\begin{array}{l}\text { (Berlese, } \\
\text { 1910) }\end{array}$ & $\begin{array}{l}\text { jungle } \\
\text { rubber }\end{array}$ & $\mathrm{BJ} 2$ & 2 & 0.569 & 0.288 & 4.123 & -27.183 \\
\hline 405449 & $\begin{array}{l}\text { Scheloribates } \\
\text { praeincisus }\end{array}$ & $\begin{array}{l}\text { (Berlese, } \\
\text { 1910) }\end{array}$ & $\begin{array}{l}\text { jungle } \\
\text { rubber }\end{array}$ & $\mathrm{BJ} 2$ & 3 & 2.502 & 0.323 & 2.958 & -27.650 \\
\hline & & & & $\mathrm{HJ} 4$ & 6 & 2.111 & 2.180 & 2.259 & -26.647 \\
\hline & & & oil palm & BO3 & 9 & 3.276 & 2.150 & 1.495 & -26.449 \\
\hline & & & & BO4 & 3 & 2.770 & 0.396 & 2.822 & -26.694 \\
\hline & & & & BO5 & 6 & 2.978 & 0.923 & 2.992 & -28.849 \\
\hline & & & & HO1 & 6 & 3.032 & 1.366 & 1.086 & -26.825 \\
\hline & & & & $\mathrm{HO} 2$ & 2 & 4.430 & 0.286 & 3.570 & -26.947 \\
\hline & & & & $\mathrm{HO} 3$ & 3 & 3.504 & 2.362 & 3.817 & -27.910 \\
\hline & & & rainforest & BF2 & 10 & 2.003 & 1.086 & 0.080 & -28.037 \\
\hline & & & & $\mathrm{BF} 3$ & 6 & 1.997 & 0.680 & 0.840 & -25.758 \\
\hline & & & & BF4 & 3 & 3.577 & 0.663 & 3.258 & -25.428 \\
\hline & & & & HF1 & 6 & 1.179 & 1.029 & 0.284 & -28.679 \\
\hline & & & & HF3 & 6 & 1.721 & 0.884 & -0.018 & -28.567 \\
\hline & & & & HF4 & 5 & 1.581 & 0.978 & -0.015 & -28.216 \\
\hline & & & rubber & BR1 & 3 & 1.441 & 0.344 & 2.034 & -25.529 \\
\hline & & & & BR2 & 4 & 3.637 & 0.967 & 5.887 & -27.126 \\
\hline & & & & BR3 & 3 & 0.744 & 1.118 & 3.653 & -28.191 \\
\hline & & & & HR1 & 10 & 2.934 & 2.530 & 4.111 & -27.602 \\
\hline & & & & HR4 & 2 & 0.954 & 0.363 & -0.852 & -28.452 \\
\hline
\end{tabular}





\section{Chapter III}

Variation in community level trophic niches of soil microarthropods with conversion of tropical rainforest into plantations systems as indicted by stable isotopes $\left({ }^{15} \mathrm{~N},{ }^{13} \mathrm{C}\right)$
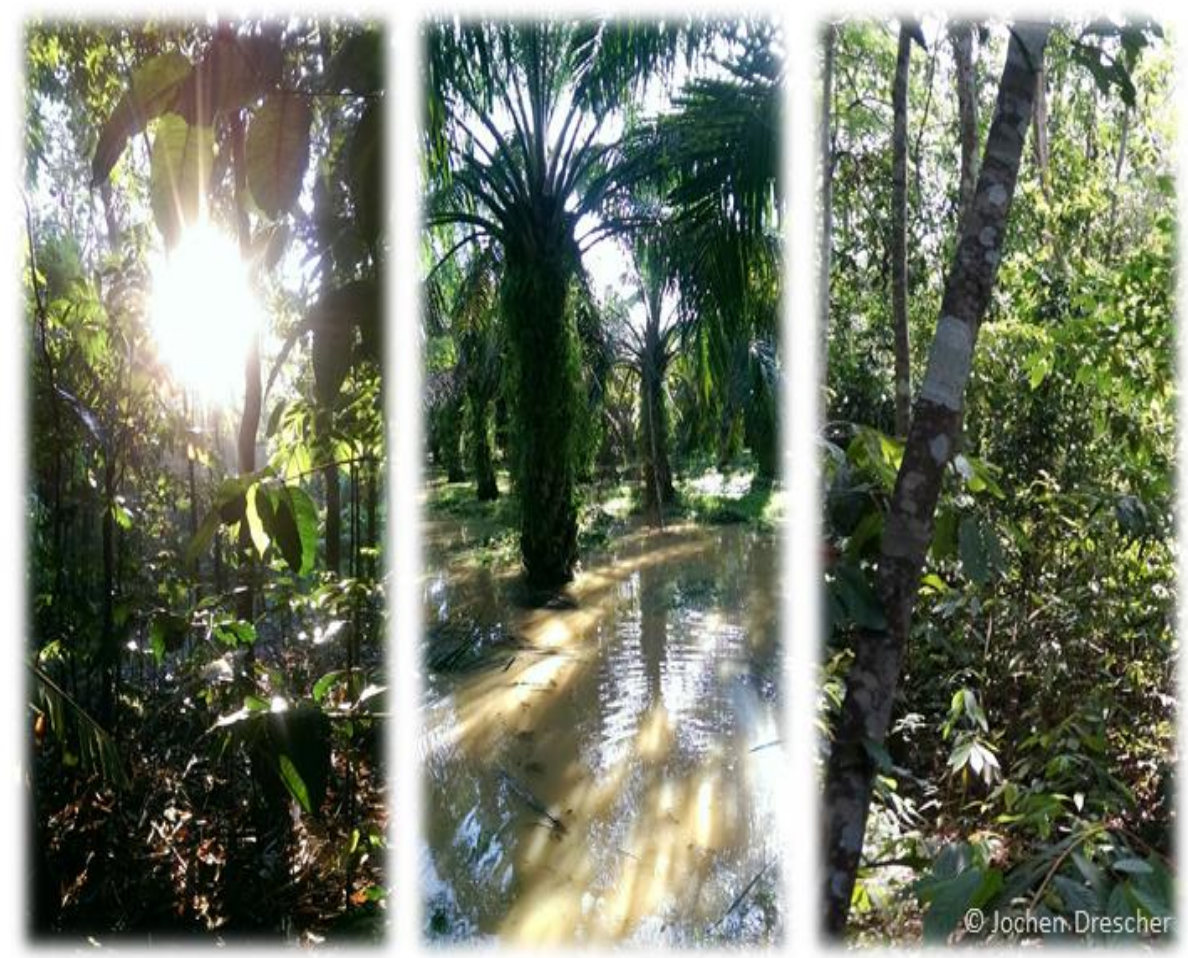

Alena Krause, Dorothee Sandmann, Anton Potapov, Sergey Ermilov, Rahayu Widyastuti, Noor Farikhah Haneda, Stefan Scheu and Mark Maraun 



\section{Abstract}

Land-use change is threatening biodiversity worldwide and is predicted to increase in the next decades, especially in tropical regions. Most studies focused on the response of single or few species to land-use change, only few investigated the response of entire communities. In particular the response of belowground communities to changes in land use received little attention. Oribatid mites (Oribatida, Acari) are among the most abundant soil animals, involved in decomposition processes and nutrient cycling. Oribatid mite species span a wide range of trophic niches and are known to sensitively respond to changes in land use. Here, we investigated shifts in the community-level trophic niche of oribatid mites with the conversion of rainforest into rubber and oil palm plantations. Due to a wider range of resources in more natural ecosystems we expected the communitylevel trophic niche to shrink with conversion of rainforest into plantations. As the conversion of rainforest into plantations is associated with reduced availability of litter resources we expected the average trophic level (indicated by the ${ }^{15} \mathrm{~N} /{ }^{14} \mathrm{~N}$ ratio) to be higher and the role of basal resources (indicated by the ${ }^{13} \mathrm{C} /{ }^{12} \mathrm{C}$ ratio) to shift towards living plant material in rubber and oil palm plantations. Our results confirm that the communitylevel trophic niche of oribatid mites in fact is wider in rainforest than in plantation systems. Additionally, the results document that the community-level trophic niche in rainforest and rubber agroforest ("jungle rubber") is separated from that in monoculture plantation systems, indicating that the trophic niche of oribatid mite communities shifts markedly with conversion of rainforest into plantation systems. Further, ${ }^{15} \mathrm{~N} /{ }^{14} \mathrm{~N}$ ratios indicate that oribatid mites in fact shift their diet towards predation and/or scavenging with transformation of rainforest into plantations, presumably due to the limited amount of 
litter and its low quality in rubber and oil palm plantations. Exceptionally low ${ }^{13} \mathrm{C} /{ }^{12} \mathrm{C}$ ratios in rubber plantations suggest that certain oribatid mite species in this land-use system use resources non-existing in the other studied ecosystems. Oribatid mite communities in plantation systems therefore have an unusual high functional richness and uniqueness compared to natural systems. 


\section{Introduction}

The niche concept forms the basis of concepts explaining the coexistence of species (Hutchinson, 1959; Chase and Leibold, 2003). There are two different niche-related process, i.e. environmental filtering, assuming that the assemblage of communities is based on the similarity of niches of the species coexisting locally, and niche differentiation resulting from competition among species (Macarthur et al., 1967; Vellend, 2010; Violle et al., 2011; Kraft et al., 2015). At stable environmental conditions long-term coexistence of species results in distinct niches of the coexisting species and in predictable community composition with pronounced niche differentiation among coexisting species (Giller, 1996). By contrast, in fragmented habitats or in systems with fluctuating environmental conditions communities are likely to be assembled at least in part at random, and therefore niches of species may overlap (Giller, 1996; Chesson, 2000; Caruso et al., 2012). Trophic niches define the impact of one species on other species based on the use of common resources and therefore are closely related to the role of species in ecosystems (Korotkevich et al., 2018). Species with broader trophic niches likely are able to better cope with disturbances, such as changes in land use or invading species, compared to species with narrower niches (Bommarco et al., 2010; Dammhahn et al., 2017). In contrast to the former, species with narrower niches are more likely to go extinct if environmental conditions and the availability of food resources change (Gan et al., 2014). The complement of trophic niches of coexisting species define the community level trophic niche which is likely to differ between ecosystems due to species turnover and changes in trophic niches of individual species (Tilman, 2004; Salles et al., 2009). These changes are 
likely to be associated with changes in the functionality of communities (Korotkevich et al., 2018).

Functional diversity, including functional richness, functional evenness and functional divergence, has been shown to increase the ecosystems functioning (Hulot et al., 2000; Pearson, 2001; Bremner et al., 2003). Moreover, it is related to certain characteristics of communities and ecosystems. Mechanisms responsible for diversity - ecosystem functioning relationships are based on the niches of species and their functional space (Tilman, 2001; Adler and Bradford, 2002). If the functional richness is low, part of the available resources remain unused by the local community, resulting in low productivity (Petchey, 2003). By contrast, increased ecosystem functioning due to efficient use of resources is based on high niche differentiation associated with low resource competition (Mason et al., 2005).

The global demand for food, fuel and fiber is associated with the transformation and degradation of ecosystems, and this is increasing rapidly (Sodhi et al., 2010; Wilcove et al., 2013; Meijide et al., 2018). Especially tropical regions are suffering (Sodhi et al., 2010; Wilcove et al., 2013; Meijide et al., 2018). Tropical forest ecosystems, characterized by the highest biodiversity and highest level of endemism worldwide, are shrinking and are transformed into intensively managed monoculture plantations at increasing rates (Myers et al., 2000; Sodhi et al., 2010; Drescher et al., 2016). Biodiversity in plantations typically is strongly reduced compared to rainforest due to reduced diversity of trees as well as more pronounced fluctuating environmental conditions (Wilcove and Koh, 2010). Reduced diversity in plantations may impair the functioning of these systems and this at 
least in part is likely to be due to changes in trophic interactions and community level trophic niches (Potapov et al., 2019a).

So far, most studies investigating shifts in trophic niches with changes in environmental conditions focused on the response of individual species to disturbances and habitat transformation, whereas changes at the level of communities have been little studied (Korotkevich et al., 2018). Further, only little is known on the effect of land-use change in tropical regions on soil organisms responsible for major ecosystem functions such as decomposition processes and nutrient cycling and this applies in particular to soil mesofauna such as oribatid mites (Maraun and Scheu, 2000; Bardgett, 2005). Oribatid mites are trophically diverse and span over four trophic levels including lichen feeders, fungal feeders, primary and secondary decomposers as well as predators/scavengers (Schneider et al., 2004; Illig et al., 2005; Maraun et al., 2011). Due to their high diversity and wide range of trophic niches oribatid mites are ideal model taxon for studying effects of land-use change on community functioning.

Natural variations in ${ }^{15} \mathrm{~N} /{ }^{14} \mathrm{~N}$ and ${ }^{13} \mathrm{C} /{ }^{12} \mathrm{C}$ ratios provide insight into the trophic niches of animal species as well as the trophic structure of animal communities (Wada et al., 1991; Newsome et al., 2007; Boecklen et al., 2011), and are increasingly used for characterizing trophic niches of soil animal species (Tiunov, 2007; Potapov et al., 2019b). Animal tissue is enriched by $3.4 \%$ per trophic level in ${ }^{15} \mathrm{~N}$, allowing to study changes in the trophic position of species with environmental changes (DeNiro and Epstein, 1978; Post, 2002; Pollierer et al., 2009; Potapov et al., 2019b). In contrast to ${ }^{15} \mathrm{~N},{ }^{13} \mathrm{C}$ is little enriched in consumers as compared to their diet, allowing to trace basal food resources in food webs (DeNiro and Epstein, 1978; Spence and Rosenheim, 2005; Pollierer et al., 2009; Potapov 
et al., 2019b). Stable isotopes have been used to analyze trophic niches of a wide range of soil invertebrates (Scheu and Falca, 2000; Halaj et al., 2005; Maraun et al., 2007, 2011; Tiunov, 2007). However, they have rarely been used to investigate how changes in trophic niches of soil organisms are affected by changes in land use (Lagerlöf et al., 2017; Minor et al., 2017; Korotkevich et al., 2018). Additionally, previous metrics for stable isotopes did not account for abundance and/or biomass of the studied species, e.g. all organisms were assumed to have the same importance or impact (Layman et al., 2007; Jackson et al., 2011). Novel techniques allow accounting for these deficiencies but have rarely been used so far (Huxel and McCann, 1998; Cucherousset and Villéger, 2015).

The current study formed part of the interdisciplinary project "Ecological and socioeconomic functions of tropical lowland rainforest transformation systems" (EFForTS), established in Jambi Province, southwest Sumatra, Indonesia (Drescher et al., 2016). By measuring natural variations in ${ }^{15} \mathrm{~N} /{ }^{14} \mathrm{~N}$ and ${ }^{13} \mathrm{C} /{ }^{12} \mathrm{C}$ ratios, we analyzed changes in the trophic structure of oribatid mite communities with conversion of rainforest into plantation systems. Four major land-use systems in Southeast Asia were investigated, i.e. rainforest, rubber agroforest ("jungle rubber"), rubber and oil palm monoculture plantations. We focused on the niche structure and overall niche position at the level of communities rather than on the changes in trophic niches of individual species, which were addressed in an earlier study (Krause et al., 2019). We hypothesized (1) that the community-level trophic niche of oribatid mites is larger in close to natural ecosystems, such as rainforest and jungle rubber, than in intensively managed agricultural systems, such as rubber and oil palm plantations. Further, we hypothesized (2) that the communitylevel trophic niche of oribatid mites is shifted in intensively managed agricultural systems 
towards living plant-based resources due to lower availability of litter resources and more open canopy allowing more pronounced growth of understory plants and algae. In addition, we hypothesized (3) that functional richness and functional redundancy in rainforest are higher compared to plantation systems due to more complex resources and more species rich oribatid mite communities.

\section{Material and Methods}

\section{Study sites}

Samples were taken in two landscapes of Jambi Province, Bukit Duabelas ( $2^{\circ} 0^{\prime} 57^{\prime \prime} \mathrm{S}, 120^{\circ}$ $\left.45^{\prime} 12^{\prime \prime} \mathrm{E}\right)$ and Harapan $\left(1^{\circ} 55^{\prime} 40^{\prime \prime} \mathrm{S}, 103^{\circ} 15^{\prime} 33^{\prime \prime} \mathrm{E}\right)$. In each landscape, four different land-use systems were investigated: rainforest, jungle rubber, rubber and oil palm plantations (Drescher et al., 2016). Rainforest sites were 'primary degraded forests' (classified by Margono et al., 2014) and had been selectively logged at least once. Jungle rubber sites were established by planting rubber trees (Hevea brasiliensis) into rainforest and contain rainforest tree species. Jungle rubber sites represent low intensive land-use systems, lacking fertilizer input as well as herbicide application. By contrast, rubber as well as oil palm (Elaeis guineensis) monocultures represent high land-use intensity plantation systems managed by the addition of fertilizers as well as herbicides. More details on the study sites are given in Drescher et al. (2016). For each land-use system four replicates were established in each of the two landscapes, resulting in a total of 32 plots. Each plot spanned $50 \times 50 \mathrm{~m}$ and included three randomly placed subplots of $5 \times 5 \mathrm{~m}$ (Drescher et al., 2016). 


\section{Sampling, extraction and species determination}

In October 2013, samples $(16 \times 16 \mathrm{~cm}$; including the litter layer and $0-5 \mathrm{~cm}$ of the mineral soil) were taken from each of the subplots, i.e. a total of 96 samples. The samples were transported to the laboratory and extracted by heat (Kempson et al., 1963). Determination of oribatid mites was done to species/morphospecies level using Balogh and Balogh (2012). Species and morphospecies were documented by pictures, linked with morphological traits and species identification numbers (species ID), and included into the Ecotaxonomy database (http://ecotaxonomy.org/). Oribatid mites were ascribed to trophic groups including lichen feeders, primary decomposer, secondary decomposer/fungal feeders and predators/scavengers based on Maraun et al. (2011). Until further analysis, species were stored in $70 \%$ ethanol. For calibration of animal stable isotope values mixed litter samples were taken from the subplots (Klarner et al., 2017).

\section{Stable isotope analysis}

For each land-use system in the two landscapes (Bukit Dubaelas and Harapan) species for stable isotope analysis were selected based on their relative abundance; for each land-use system species representing $80 \%$ of total oribatid mite individuals were analyzed (Table S1). These species were assumed to represent the functional niche of the community of oribatid mites of the respective land-use system. Three individuals (if present) were pooled for one sample (sample weight $0.02-0.19 \mathrm{mg}$ ). In total, 367 samples including all the species (117) contributing to $80 \%$ of the individuals sampled were analyzed (out of the total of 220 species occurring at the study sites; D. Sandmann, unpubl. data). 
Prior to stable isotope analysis samples were dried at $60^{\circ} \mathrm{C}$ for $24 \mathrm{~h}$. Litter samples were grinded in a ball mill (Retsch Mixer Mill MM200, Haan, Germany) prior to stable isotope measurement. Samples were analyzed using a coupled system of an elemental analyzer (NA 1500, Carlo Erba, Milan, Italy) and a mass spectrometer (MAT 251, Finnigan, Bremen, Germany) adopted for the analysis of small sample sizes (Langel and Dyckmans, 2014). Stable isotope abundance $(\delta X)$ was expressed using the $\delta$ notation with $\delta \mathrm{X}(\%)=$ $\left(R_{\text {sample }}-R_{\text {standard }}\right) / R_{\text {standard }} X 1000$, with $X$ representing the target isotope $\left({ }^{15} \mathrm{~N}\right.$ or $\left.{ }^{13} \mathrm{C}\right)$ and $R_{\text {sample }}$ and $R_{\text {standard }}$ the respective target isotope ratio $\left({ }^{15} \mathrm{~N} /{ }^{14} \mathrm{~N}\right.$ or $\left.{ }^{13} \mathrm{C} /{ }^{12} \mathrm{C}\right)$. As standard for ${ }^{13} \mathrm{C}$ Vienna PD Belemnite and for ${ }^{15} \mathrm{~N}$ atmospheric nitrogen were used. Acetanilid was used for internal calibration.

\section{Statistical analysis}

Means of $\delta^{13} \mathrm{C}$ and $\delta^{15} \mathrm{~N}$ values of litter samples across subplots were used for calibration of stable isotope values of oribatid mites of the respective plot. Calibrated $\delta^{13} \mathrm{C}$ and $\delta^{15} \mathrm{~N}$ values were calculated as difference between the plot-specific litter $\delta^{13} \mathrm{C}$ and $\delta^{15} \mathrm{~N}$ values, and the mean $\delta^{13} \mathrm{C}$ and $\delta^{15} \mathrm{~N}$ value of oribatid mite species, and given as $\Delta^{13} \mathrm{C}$ and $\Delta^{15} \mathrm{~N}$ values, respectively. Calibrated values were used for statistical analyses.

For characterizing the trophic structure of communities we calculated 'isotopic metrics' (Layman et al., 2007; Cucherousset and Villéger, 2015). These metrics describe the position of species of a studied community within two-dimensional space, represented by $\delta^{15} \mathrm{~N}$ and $\delta^{13} \mathrm{C}$ values and included, among others, the convex hull area, which is the 'smallest area' that is filled by all species within the studied community (Layman et al., 2007). Cucherousset and Villéger (2015) further developed metrics based on the ones 
from Layman et al. (2007), by merging them with the functional diversity metrics suggested by Villéger et al. (2008) and Laliberté and Legendre (2010). These metrics are mathematically independent of the number of species and account for the abundance or biomass of the studied species (Cucherousset and Villéger, 2015). Additionally, they provide a process for scaling stable isotope axes, which allows to quantify isotopic diversity as well as the levels of potential isotopic overlap between species.

Statistical analyses were performed using R v 3.5.2 (R Core Team, 2018) with R studio interface (RStudio, Inc.). We used the R script provided by Cucherousset and Villeger (2015) to scale two stable isotope axes and calculate isotopic metrics for each community. $\Delta{ }^{13} \mathrm{C}$ and $\Delta{ }^{15} \mathrm{~N}$ values were scaled between 0 and 1 based on maximum and minimum across communities to ensure equal contribution of two isotopes in the multidimensional metric calculation. Before calculating community mean values and multidimensional metrics, species were weighted according to their contribution to the total community biomass per plot and therefore, those metrics were adjusted according to the functional relevance of the species. Individual body mass of oribatid mite species were calculated from individual measurements of body length and width (D. Sandmann, unpubl. data) using the allometric regression $\log P=1.53 \times \log L+1.53 \times \log I-6.67$, with $P$ body mass, $L$ body length and I body width (Lebrun, 1971). First, we calculated single-dimensional metrics - minimum, maximum, range and mean for $\Delta^{13} \mathrm{C}$ and $\Delta^{15} \mathrm{~N}$ values for each community. Maximum as well as minimum $\Delta^{13} \mathrm{C}$ and $\Delta^{15} \mathrm{~N}$ values were represented by one species with the most extreme values within the community. Second, we calculated five multidimensional metrics including isotopic divergence ('IDiv'), isotopic dispersion ('IDis'), isotopic evenness ('IEve'), isotopic uniqueness ('IUni') and isotopic richness ('IRic') 
(Cucherousset and Villéger, 2015). In addition to the convex hull area (Layman et al., 2007) 'IDiv' is weighting stable isotope values according to the biomass of species and showing the distance between all species as well as the center of the convex hull area. 'IDiv' values close to 0 indicate that species with the most extreme stable isotope values, e.g. primary decomposers and predators, are rare, whereas 'IDiv' values close to 1 indicate that species with the most extreme stable isotope values are among the dominant species. 'IDis' reflects the convex hull area but also isotopic divergence and therefore can be interpreted as scaled multidimensional variance. 'IDis' is a generalized version of the 'centroid distance' (Layman et al., 2007) but accounts for the relative contribution of species to community biomass. 'IDis' approaches 1 when most stable isotope values are fare from the center of the group, i.e. species with contrasting stable isotope values but similar abundance, e.g. primary and high-level consumers, whereas 'IDis' approaches 0 if stable isotope values of the species differ little. In contrast to 'IDiv' and 'IDis', which do not consider the distance between species, 'IEve' quantifies the distribution of species in stable isotope space weighted by biomass. 'IEve' values close to 1 indicate that the isotope values of the species of the studied community are evenly distributed. By contrast, 'IEve' values close to 0 indicate that most stable isotope values of the studied species cluster together indicating e.g., that there are mostly herbivore and only few predator species. 'IUni', is defined as the inverse of the average isotopic redundancy, which reflects the closeness of stable isotope values of the studied species within the community. 'IUni' equals 0 if stable isotope values of species among communities are similar indicating, e.g. that species of different communities occupy a similar isotope range. By contrast, 'IUni' is close to 1 if stable isotope values of species differ among communities indicating that e.g., the isotope values of species with high biomass are very different from those of the other 
species of the community. Contrary to the latter, 'IRic' calculates community properties based on the size and position of isotope niches among species. 'IRic' represents the functional richness i.e., the functional space filled by the community (Villéger et al., 2008). For single trait approaches functional richness reflects the difference between the maximum and minimum trait values of the community (Mason et al., 2005). To calculate functional richness for multiple traits the convex hull area occupied by a community is used as multidimensional measure (Cornwell et al., 2006; Layman et al., 2007; Villéger et al., 2008). Functional richness does not have an upper limit as it represents a volume, which depends on the number of traits and their units, however, functional richness values may be limited by 0 and 1 due to standardization of the hull volume, e.g. the volume occupied by all studied species (Mason et al., 2005; Villéger et al., 2008).

Data were analyzed using the aov (analysis of variance) function with landscape and landuse system as factors followed by post-hoc comparison of means using HSD.test function to inspect differences between land-use systems. Results were displayed using the ggplot2 package (Wickham, 2016). The baseline was represented by zero (Figs. 2, 3). Communities were represented by points in graphs. Oribatid mites were ascribed to trophic levels assuming an enrichment of ${ }^{15} \mathrm{~N}$ by $3.4 \%$ per trophic level except for primary decomposer which were assumed to be only enriched in ${ }^{15} \mathrm{~N}$ by a maximum of $1.7 \%$ compared to litter (Vanderklift and Ponsard, 2003; Potapov et al., 2019b). 


\section{Results}

\section{Trophic structure}

As indicated by ${ }^{15} \mathrm{~N}$ values, rainforest, jungle rubber and rubber plantations harbored species spanning over three trophic levels including primary and secondary decomposers as well as predators (Fig. S1a-c). By contrast, oil palm plantations lacked primary decomposers and only comprised secondary decomposers and predators (Fig. S1d). Additionally, rainforest and rubber plantations harbored species with stable isotope values lower than those of litter (Fig. S1a and S1C). In rubber plantations some oribatid mite species were highly depleted in ${ }^{13} \mathrm{C}$ relative to the litter baseline (up to $6 \%$; Fig. S1c). Calibrated stable isotope values of oribatid mite communities of the four land-use systems separated the two more natural systems from the two monoculture plantations (Fig. 1). Notably, rainforest and jungle rubber as well as oil palm and rubber plantations overlapped widely. 


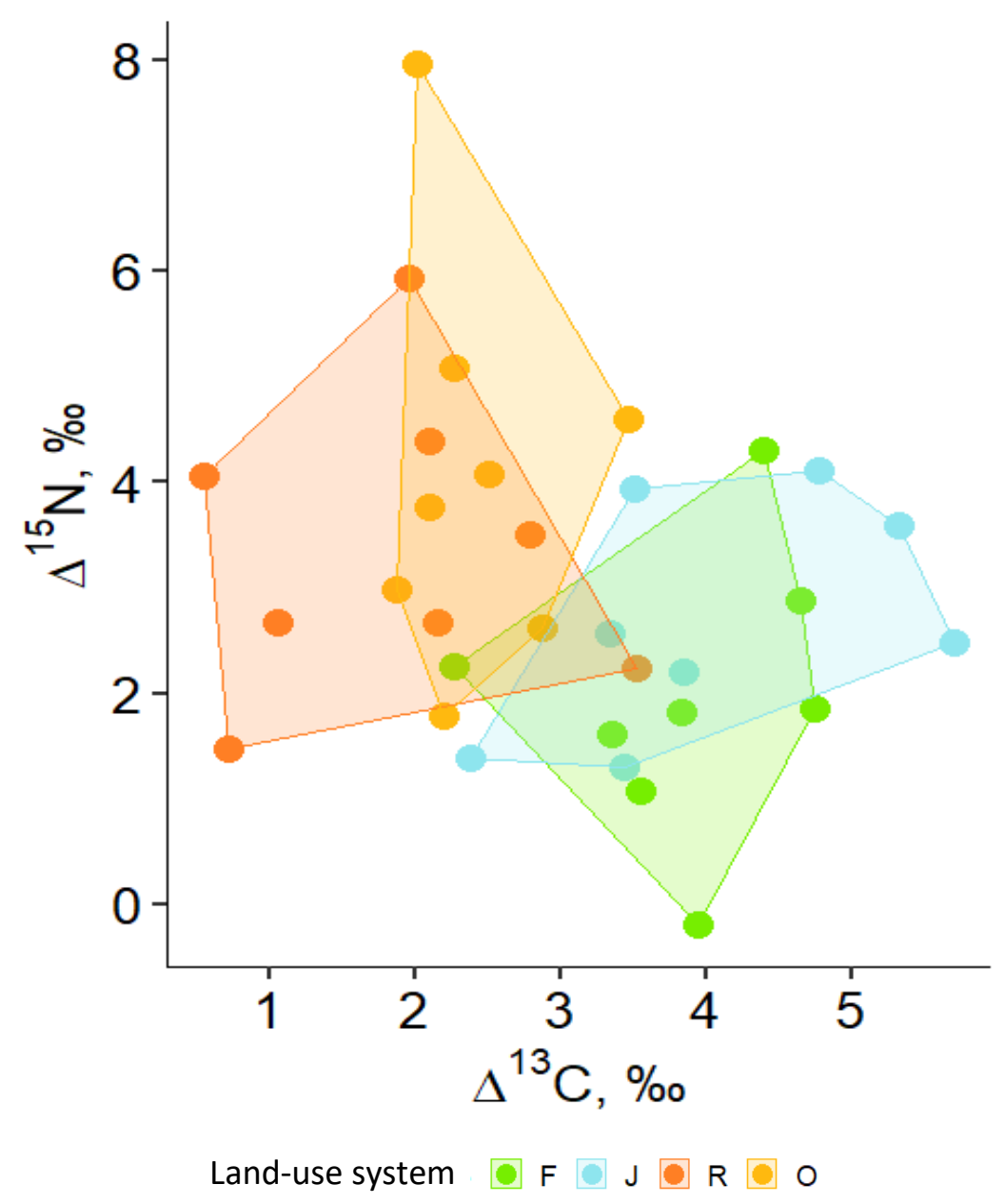

Figure 1: Average $\Delta^{13} \mathrm{C}$ and $\Delta^{15} \mathrm{~N}$ stable isotope values of oribatid mite communities in rainforest (green), jungle rubber (blue), rubber (red) and oil palm plantations (orange) (eight replicates each). Each point represent the average position of oribatid mite communities per replicate land-use system; for each land-use system eight replicates were studied (four in each of two landscapes).

\section{One-dimensional metrics}

Similar to the calibrated stable isotope values, the average community positions of $\Delta^{13} \mathrm{C}$ and $\Delta^{15} \mathrm{~N}$ values ('IPos') indicated separation of more natural systems and plantation systems (Figs. 2a - e). The average community positions of both $\Delta^{13} \mathrm{C}$ and $\Delta^{15} \mathrm{~N}$ values varied significantly between the land-use systems $\left(F_{3,27}=7.09, p<0.001\right.$ for $\Delta^{13} C$ and $F_{3,27}=$ 
7.93, $\mathrm{p}=<0.001$ for $\Delta^{15} \mathrm{~N}$ ). Average community positions of $\Delta^{13} \mathrm{C}$ were similar in rainforest and jungle rubber, but significantly lower in rubber and oil palm plantations, on average by $1.58 \%$ (Fig. 2a; Table S2). By contrast, average community positions of $\Delta^{15} \mathrm{~N}$ were similar in rubber and oil palm plantations, but significantly lower in jungle rubber, on average by $1.79 \%$, and in rainforest, on average by $3.03 \%$ (Fig. 2e; Table S2).

Maximum $\Delta^{13} \mathrm{C}$ values, but not maximum $\Delta^{15} \mathrm{~N}$ values, varied significantly with land-use system $\left(F_{3,27}=7.22, p=0.001\right.$ for $\Delta^{13} C$ and $F_{3,27}=0.41, p=0.74$ for $\left.\Delta^{15} N\right)$. Maximum $\Delta^{13} C$ values were similar in rainforest, jungle rubber and rubber plantations, but significantly lower in oil palm plantations, on average by 2 \%o (Fig. 2b; Table S2). Further, minimum $\Delta^{13} \mathrm{C}$ and $\Delta^{15} \mathrm{~N}$ values varied significantly with land-use system $\left(F_{3,27}=19.51, p<0.001\right.$ for $\Delta^{13} \mathrm{C}$ and $\mathrm{F}_{3,27}=10.56, \mathrm{p}=<0.001$ for $\left.\Delta^{15} \mathrm{~N}\right)$. Minimum $\Delta^{13} \mathrm{C}$ were similar in rainforest, jungle rubber and oil palm plantations, but significantly lower in rubber plantations, on average by $4.46 \%$. By contrast, minimum $\Delta^{15} \mathrm{~N}$ values were similar in rainforest, jungle rubber and rubber plantations, but significantly higher in oil palm plantations, on average by $4.15 \%$ (Fig. 2g; Table S2).

Similar to the previous metrics, the range between maximum and minimum $\Delta^{13} \mathrm{C}$ and $\Delta^{15} \mathrm{~N}$ values varied significantly between land-use system $\left(F_{3,27}=16.31 p=0.005\right.$ for $\Delta^{13} C$ and $F_{3,27}=5.18 p=0.006$ for $\left.\Delta^{15} N\right)$. The range in $\Delta^{13} \mathrm{C}$ values was similar in rainforest, jungle rubber and oil palm plantations, but significantly higher in rubber plantations, on average by $4.87 \%$ o (Fig. 2 d; Table S2). By contrast, the range in $\Delta^{15} \mathrm{~N}$ values was similar in rainforest and rubber plantations, but significantly lower in jungle rubber, on average by $2.52 \%$, and in oil palm plantations, on average by $4.94 \%$ (Fig. 2h) (Table S2). 
a)

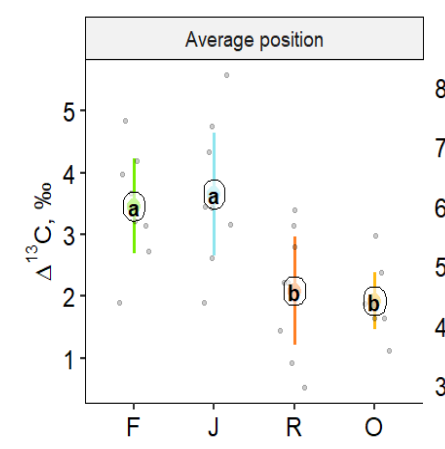

e)

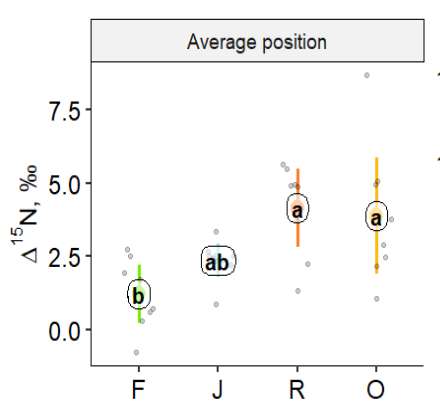

b)

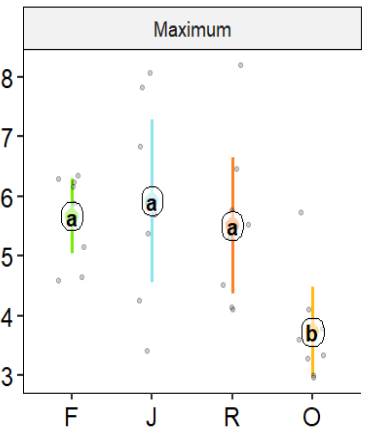

f)

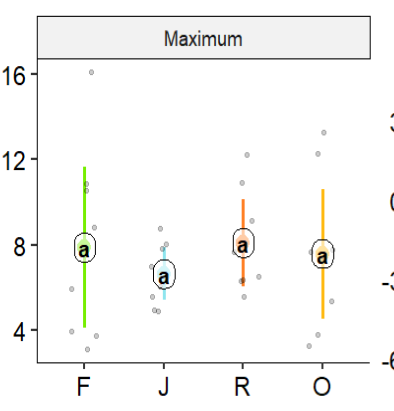

c)

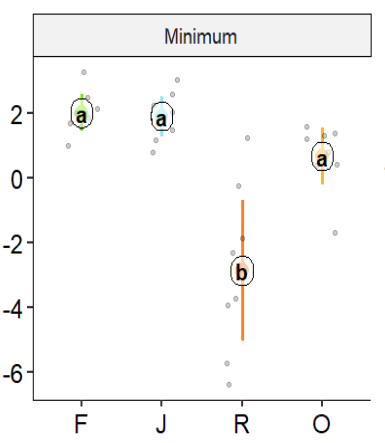

g)

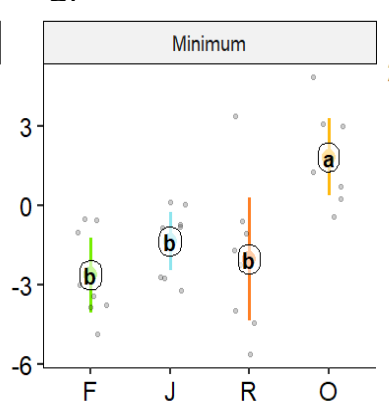

d)

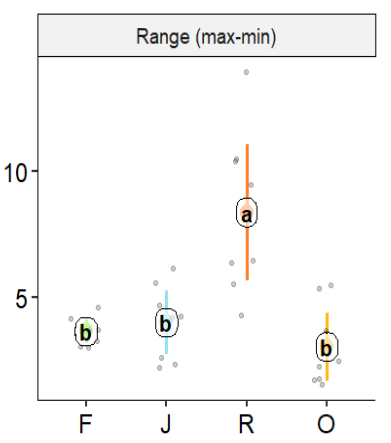

h)

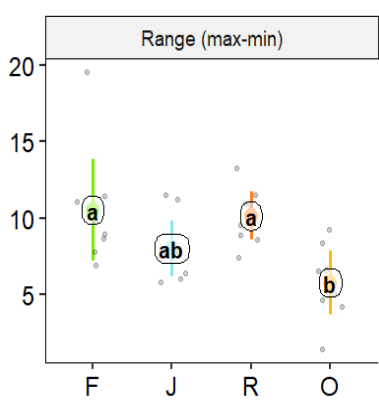

Land-use system $\bullet \mathrm{F} \diamond \mathrm{R} \diamond \mathrm{O}$

Figure 2. One-dimensional metrics for $\Delta^{13} \mathrm{C}$ (upper panel) and $\Delta^{15} \mathrm{~N}$ values (lower panel) of oribatid mite communities. Average position ( $a, e)$, maximum (b, f), minimum (c, g) and range between minimum and maximum (d, h); means (circles) and confidence intervals. Each point represents one community. For the calculation of the metrics see Methods and Table S2. For the calculation of the average positions, species were weighted according to their contribution to the total community biomass per plot. Means, sharing the same letter are not significantly different (Tukey's HSD test, $\mathrm{P}<0.05)$.

\section{Multidimensional metrics}

For the multidimensional metrics $\Delta^{13} \mathrm{C}$ and $\Delta^{15} \mathrm{~N}$ values were scaled between 0 and 1 (without units). Isotopic dispersion ('IDis'), isotopic divergence ('IDiv') and isotopic evenness ('IEve') did not differ significantly between the four land-use systems (Figs. 3a-c) 
('IDis' $F_{3,27}=1.65 p=0.201 ;$ 'IDiv' $F_{3,27}=0.46 p=0.714$; 'IEve' $F_{3,27}=1.53 p=0.228$ ). By contrast, isotopic richness ('IRic') varied significantly between the land-use systems $\left(F_{3,27}\right.$ $=8.1 \mathrm{p}=<0.001)$; it was similar in rainforest, jungle rubber and oil palm plantations, but significantly higher in rubber monoculture plantations, on average by 0.11 (Fig. 3d; Table S3). Further, isotopic uniqueness ('IUni') varied significantly with land-use system $\left(F_{3,27}=\right.$ $5.33 p=0.005)$; it increased from rainforest to jungle rubber and rubber plantations to oil palm plantations, in total by 0.3 (Fig. 3e; Table S3). For detailed information on plot level metrics values see Appendix (Figs S2 - S9).
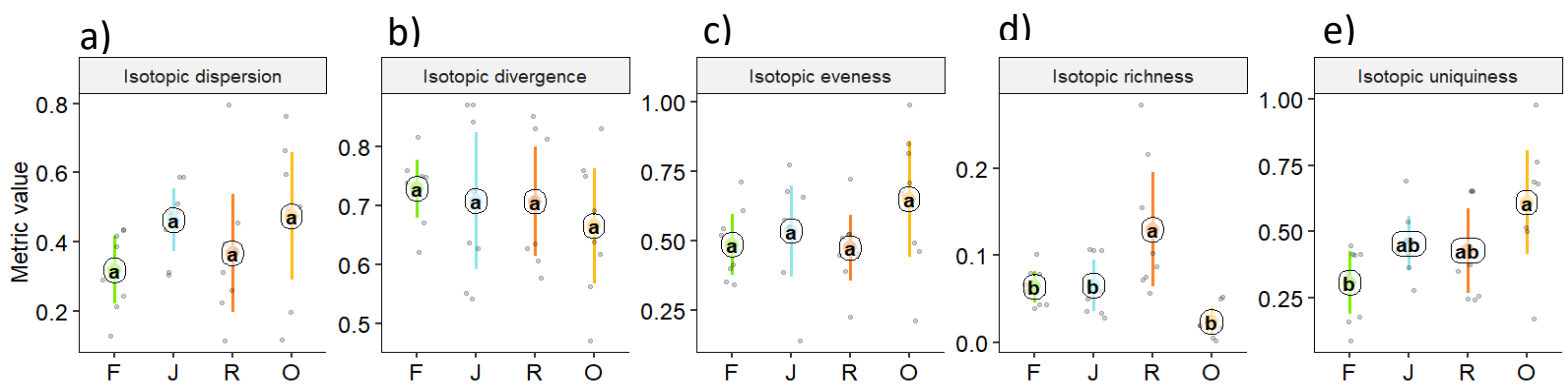

Land-use system $\quad \mathrm{F} \gg \mathrm{J} \otimes \mathrm{O}$

Figure 3: Multidimensional isotopic metrics of oribatid mite communities of four land-use systems, rainforest $(F)$, jungle rubber $(J)$, rubber $(R)$ and oil palm plantations $(O)-(a)$ isotopic dispersion ('IDis'), (b) isotopic divergence ('IDiv'), (c) isotopic evenness ('IEve'), (d) isotopic richness ('IRic') and (e) isotopic uniqueness ('IUni') Each point represents one community, means (circles) and confidence intervals. For calculations see Methods and Table S3. For the calculation of the metrics, species were weighted according to their contribution to the total community biomass per plot. Means sharing the same letter are not significantly different (Tukey's HSD test, $\mathrm{P}<0.05$ ). 


\section{Discussion}

We investigated effects of land-use change on the trophic ecology of oribatid mite communities as model taxon of soil invertebrates and the decomposer food web. The study adds to the few existing studies investigating changes in community trophic niches and energy fluxes (Korotkevich et al., 2018; Susanti et al., 2019). We investigated shifts in the community-level trophic niche of oribatid mites with the conversion of rainforest into rubber and oil palm plantations. Oribatid mite communities were represented by the species accounting for $80 \%$ of total oribatid mite individuals as functional community. The results indicate that the community niche of oribatid mites differs most between more natural (rainforest and jungle rubber) and monoculture plantation systems (rubber and oil palm plantations). Further, the results indicate that in rubber monoculture plantations oribatid mites use basal resources not existing in any of the other studied land-use systems. In addition, the results indicate that in oil palm plantations trophic chains are shorter than in the other land-use systems.

\section{One-dimensional metrics}

Generally, both $\Delta^{13} \mathrm{C}$ and $\Delta^{15} \mathrm{~N}$ values were similar in rainforest and jungle rubber and distant from those in oil palm and rubber plantations, indicating that trophic niches in the more natural systems are similar and markedly different from those in the two plantation systems with trophic niches in the more natural as well as the two monoculture plantation systems differing little. This supports findings of Krause et al. (2019) who analyzed individual oribatid mite species and showed that trophic niches shifted most from 
rainforest to monoculture plantation systems. These changes were due to both changes in the use of basal resources as well as trophic level and indicated trophic plasticity of oribatid mite species. Using fatty acids as trophic markers Susanti et al. (2019) found strong changes in the flux of energy through soil food webs with the conversion of rainforest into rubber and oil palm plantations. Changes in energy channels with land-use intensity suggest that soil fauna communities are able to response in a flexible way to changes in the availability of resources. In rainforest energy in soil food webs is channeled mainly to higher trophic levels via the bacterial energy channel, whereas in oil palm plantations the plant-based channel is more important (Susanti et al., 2019). Results of the study of Susanti et al. (2019) further suggest that in tropical ecosystems algae play an important role as food resource for Collembola and Oribatida. Furthermore, generalist predator such as centipedes (Chilopoda) have been shown to switch from decomposer prey to other prey, predominantly herbivore species, in monoculture plantations, presumably due to reduced or lacking litter layer in the latter two systems (Klarner et al., 2017). The amount of leaf litter in the litter layer in natural ecosystems typically is higher than in planation systems (Hyodo et al., 2015), and this also applies to the ecosystems investigated the present study (Krashevska et al., 2017). In our study the litter layer in oil palm plantations was lacking or poorly developed, whereas in oil palm a dense herb layer of mostly introduced weeds was present (Drescher et al., 2016). Similar to the results of Susanti et al. (2019) the shift towards lower $\Delta^{13} \mathrm{C}$ values in oribatid mite communities in our study indicates that conversion of rainforest into plantation systems is associated with a strengthening of the plant-based energy channel in plantation systems. By contrast, high $\Delta^{13} \mathrm{C}$ values in rainforest and jungle rubber indicated that soil food webs in the natural 
systems are predominantly based on microbial energy channels (Potapov et al., 2013, 2019b).

Maximum $\Delta^{13} \mathrm{C}$ values of oribatid mite communities (reflecting one species with the most extreme values from the community) were significantly lower in oil palm plantations compared to the other three land-use systems, indicating that compared to the other land-use systems oribatid mites in oil palm plantations lack certain basal resources and trophic niches. Presumably, this reflects the virtual absence of litter in oil palm plantations associated with the lack of primary decomposers, which is supported by the absence of species with low $\Delta^{15} \mathrm{~N}$ values. Soil animals typically are enriched in ${ }^{13} \mathrm{C}$ by $3-4 \delta$ units compared to litter ("detrital shift"; (Pollierer et al., 2009; Potapov et al., 2019) and therefore, the lower maximum $\Delta^{13} \mathrm{C}$ values and associated less pronounced detrital shift in oribatid mites in oil palm plantations presumably again reflect that oribatid mites (as well as other detritivores, see above) predominantly rely on freshly fixed plant carbon rather than microbial energy channels. Labile litter compounds which are easy to digest, such as sugars and proteins, are more abundant in fresh plant material (including algae) than in litter, and are often enriched in ${ }^{13} \mathrm{C}$ (Gleixner et al., 1993), whereas structural compounds which are difficult to digest, such as lignin and cellulose, are more depleted (Benner et al., 1987).

Minimum $\Delta^{13} \mathrm{C}$ values of oribatid mite communities were significantly lower (reflecting one species with the most extreme values from the community) in rubber plantations (up to $6 \%$ ) than in the other three land-use systems, indicating that oribatid mites in rubber plantations use some basal resources with exceptionally low $\delta^{13} \mathrm{C}$ values not available in the other land-use systems. Potentially, this reflects the use of carbon from understory 
plants and algae which assimilated $\mathrm{CO}_{2}$ originating from decomposing organic matter (canopy effect; (Van der Merwe and Medina, 1991). However, this is unlikely to explain the difference in minimum $\Delta^{13} \mathrm{C}$ values of oribatid mite communities between rubber plantations and the other land-use systems studied as neither the abundance of algae nor of understory plants is higher in rubber monoculture plantations than in the other landuse systems studied (Rembold et al., 2017; Schulz et al., 2019; Susanti et al., 2019). Another possibility might be that low $\Delta^{13} \mathrm{C}$ values of oribatid mite communities reflect the use of plant compounds depleted in ${ }^{13} \mathrm{C}$ such as lignin (Bowling et al., 2008; Pollierer et al., 2009). However, the use of lignin as carbon source is also unlikely since - with very few exceptions - animals are unable to digest lignin (Berg and Ryszard, 2005).

Due to the very low minimum $\Delta^{13} \mathrm{C}$ values in oribatid mites of rubber plantations the range of $\Delta^{13} \mathrm{C}$ values was significantly higher as compared to the other three land-use systems, again reflecting that in rubber plantations certain oribatid mite species use resources depleted in ${ }^{13} \mathrm{C}$ which are not available in the other land-use systems. Very high ${ }^{13} \mathrm{C}$ values in jungle rubber and rubber such as in Plonaphacarus kugohi presumably are due to the incorporation of calcium carbonate in their exoskeleton (Norton and Behan-Pelletier, 1991; Maraun et al., 2011; Pachl et al., 2012).

In contrast to maximum and minimum ${ }^{13} \mathrm{C}$ values, maximum $\Delta{ }^{15} \mathrm{~N}$ values of oribatid mites did not significantly differ between land-use systems. However, minimum $\Delta^{15} \mathrm{~N}$ values were significantly higher in oil palm plantations compared to the other three land-use systems reflecting the lack of primary decomposers in oil palm plantations (see above). Earlier studies also showed that in tropical ecosystems primary decomposers are scarce 
or lacking (Illig et al., 2005) and this likely is related to litter of poor quality (Butenschoen et al., 2014; Marian et al., 2017).

Generally, trophic level enrichment in ${ }^{15} \mathrm{~N}$ in primary decomposers is lower than in secondary decomposers and predators (Scheu and Falca, 2000; Vanderklift and Ponsard, 2003). Potentially, this is due to nitrogen limitation of primary decomposers (Yoneyama et al., 1997) and low litter quality (Cornejo et al., 1994). Oribatid mites may switch from feeding on detritus to scavenging or predation, e.g. by feeding on nematodes (Heidemann et al., 2011, 2014). For centipedes it has been shown that they switch from decomposer prey in rainforest to herbivore prey in oil palm presumably due to the rich understory in oil palm plantations, indicating that diet switching contributes to the colonization of very different land-use systems by soil animals (Klarner et al., 2017).

\section{Multidimensional metrics}

Isotopic dispersion ('IDis'), isotopic divergence ('IDiv') and isotopic evenness ('IEve') did not differ significantly between the four land-use systems indicating that the oribatid mite communities in the studied land-use systems are rather balanced and lack species occupying extreme trophic positions. Presumably, at least in part this reflects the ability of oribatid mite species to adapt to local resources (Krause et al., 2019).

In contrast to the three metrics above, isotopic richness ('IRic') was significantly higher in rubber plantations than in the three other land-use systems studied, confirming the results of isotopic ranges and reflecting a more tight functional space filling by oribatid mite communities of this system (Cucherousset and Villéger, 2015). Further, isotopic uniqueness ('IUni') in oil palm plantations exceeded that in the other three land-use 
systems, with jungle rubber and rubber plantations being intermediate between oil palm plantations and rainforest. High 'IUni' values indicate that the community harbors species with very different stable isotope values, e.g. feeding exclusively on certain resources not or little consumed by other species (Cucherousset and Villéger, 2015). High values in oil palm plantations and low values in rainforest therefore suggest low functional redundancy in the former and high functional redundancy in the latter. This indicates that the loss of species is more likely to be associated with a loss of functions in oil palm plantations than in rainforest.

\section{Conclusions}

Our results document that oribatid mites in tropical ecosystems occupy a wide range of trophic niches allowing insight into changes in the structure and functioning of decomposer systems with changes in land use. Changes in community-level trophic niches with conversion of rainforest into plantation systems were due to both changes in trophic position ( $\Delta^{15} \mathrm{~N}$ values) as well as the use of basal resources $\left(\Delta^{13} \mathrm{C}\right.$ values). Notably, changes in the use of basal resources were more prominent and consistent than those in trophic positions, indicating that changes in resource use with transformation of rainforest into plantations are more pronounced than changes in trophic level. Oribatid mite communities in both monoculture plantation systems studied had lower $\Delta^{13} \mathrm{C}$ values indicating that the decomposer food web in these systems relies more heavily on plantbased resources, whereas the decomposer food web in rainforest and jungle rubber is based predominantly on microorganisms and litter-based resources. Further, higher average $\Delta^{15} \mathrm{~N}$ values in oribatid mites of monoculture plantation systems compared to 
rainforest and jungle rubber indicate the scarcity or lack of primary decomposers in the former. High isotopic richness ('IRic') and exceptionally low $\Delta^{13} \mathrm{C}$ values in rubber plantations indicate that oribatid mite communities in this system are functionally diverse and use carbon resources not existing in the other land-use systems studied, but the identity of these resources remains enigmatic. High isotopic uniqueness ('IUni') in oil palm plantations suggest that in particular these plantations are susceptible to losses of function with the loss of species. Overall, the results document that conversion of rainforest into plantation systems is associated with pronounced shifts in community level trophic niches of detritivores, which are likely associated with changes in the functioning of the decomposer system and the channeling of energy through the decomposer food web.

\section{Acknowledgments}

\section{Funding}

This study was funded by the Deutsche Forschungsgemeinschaft (DFG, German Research Foundation) - project number 192626868 - SFB 990 in the framework of the collaborative German - Indonesian research project CRC990.

\section{Field work permissions}

The study was conducted based on the research permits no. 332/SIP/FRP/SM/IX/2012, 389/SIP/FRP/SM/X/2013 and 145/SIP/FRP/SM/V/2013 issued by the State Ministry of Research and Technology of the Republic of Indonesia (RISTEK), and the collection permit 
no. S.07/KKH-2/2013 issued by the Ministry of Forestry of the Republic of Indonesia.

Sample export for analysis in Germany was based on permit no. 125/KKH-5/TRP/2014

issued by the Ministry of Forestry of the Republic of Indonesia.

\section{Sample collection and determination}

We thank Bernhard Klarner for collecting the samples as well as Svenja Meyer, Kristina

Richter, Anneliese Beckendorff and Melissa Jüds for help in determining oribatid mites.

Furthermore, we thank the staff of the Kompetenzzentrum Stabile Isotope Göttingen

(KOSI) for measurement of stable isotopes.

\section{References}

Adler, P.B., Bradford, J.B., 2002. Compensation: An alternative method for analyzing diversity-productivity experiments. Oikos $96,411-420$.

Balogh, P., Balogh, J., 2012. The soil mites of the world: Vol. 3: Oribatid mites of the neotropical region II, 3rd ed. Elsevier.

Bardgett, R., 2005. The biology of soil: A community and ecosystem approach. Oxford University Press.

Benner, R., Fogel, M.L., Sprague, E.K., Hodson, R.E., 1987. Depletion of ${ }^{13} \mathrm{C}$ in lignin and its implications for stable carbon isotope studies 329, 708-710.

Berg, B., Ryszard, L., 2005. Decomposers: Soil microorganisms and animals. Advances in Ecological Research 38, 73-100.

Boecklen, W.J., Yarnes, C.T., Cook, B.A., James, A.C., 2011. On the use of stable isotopes in trophic ecology. Annual Review of Ecology, Evolution, and Systematics 42, 411-440.

Bommarco, R., Biesmeijer, J.C., Meyer, B., Potts, S.G., Pöyry, J., Roberts, S.P.M., Steffan-Dewenter, I., Ockinger, E., 2010. Dispersal capacity and diet breadth modify the response of wild bees to habitat loss. Proceedings of the Royal Society B: Biological Sciences 277, 2075-2082.

Bowling, D.R., Pataki, D.E., Randerson, J.T., 2008. Carbon isotopes in terrestrial ecosystem pools and $\mathrm{CO}_{2}$ fluxes. New Phytologist 178, 24-40.

Bremner, J., Rogers, S.I., Frid, C.L.J., 2003. Assessing functional diversity in marine benthic ecosystems: A comparison of approaches. Marin Ecology Progress Series 254, 11-25. 
Caruso, T., Taormina, M., Migliorini, M., 2012. Relative role of deterministic and stochastic determinants of soil animal community: A spatially explicit analysis of oribatid mites. Journal of Animal Ecology 81, 214-221.

Chase, J.M., Leibold, M.A., 2003. Ecological niches: Linking classical and contemporary approaches. University of Chicago Press.

Chesson, P., 2000. General theory of competitive coexistence in spatially-varying environments. Theoretical Population Biology 58, 211-237.

Cornejo, F.H., Varela, A., Wright, S.J., 1994. Tropical forest litter decomposition under seasonal drought: Nutrient release, fungi and bacteria. Oikos 183-190.

Cornwell, W.K., Schwilk, D.W., Ackerly, D.D., 2006. A trait-based test for habitat filtering: Convex hull volume. Ecology 87, 1465-1471.

Cucherousset, J., Villéger, S., 2015. Quantifying the multiple facets of isotopic diversity: New metrics for stable isotope ecology. Ecological Indicators 56, 152-160.

Dammhahn, M., Randriamoria, T.M., Goodman, S.M., 2017. Broad and flexible stable isotope niches in invasive non-native Rattus spp. in anthropogenic and natural habitats of central eastern Madagascar. BMC Ecology 17, 1-13.

DeNiro, M.J., Epstein, S., 1978. Influence of diet on the distribution of nitrogen isotopes in animals. Geochimica et Cosmochimica Acta 45, 341-351.

Drescher, J., Rembold, K., Allen, K., Beckscha, P., Buchori, D., Clough, Y., Faust, H., Fauzi, A.M., Gunawan, D., Hertel, D., Irawan, B., Jaya, I.N.S., Klarner, B., Kleinn, C., Knohl, A., Kotowska, M.M., Krashevska, V., Krishna, V., Leuschner, C., Lorenz, W., Meijide, A., Melati, D., Steinebach, S., Tjoa, A., Tscharntke, T., Wick, B., Wiegand, K., Kreft, H., Scheu, S., 2016. Ecological and socio-economic functions across tropical land use systems after rainforest conversion. Philosophical Transactions of the Royal Society of London. Series B, Biological Sciences 231, 1-7.

Gan, H., Zak, D.R., Hunter, M.D., 2014. Trophic stability of soil oribatid mites in the face of environmental change. Soil Biology and Biochemistry 68, 71-77.

Giller, P.S., 1996. The diversity of soil communities, the "poor man"s tropical rainforest'. Biodiversity and Conservation 5, 135-168.

Gleixner, G., Danier, H.J., Werner, R.A., Schmidt, H.L., 1993. Correlations between the ${ }^{13} \mathrm{C}$ content of primary and secondary plant products in different cell compartments and that in decomposing Basidiomycetes. Plant Physiology 102, 1287-1290.

Halaj, J., Peck, R.W., Niwa, C.G., 2005. Trophic structure of a macroarthropod litter food web in managed coniferous forest stands: A stable isotope analysis with $\delta^{15} \mathrm{~N}$ and $\delta^{13} \mathrm{C}$. Pedobiologia 49, 109-118.

Heidemann, K., Hennies, A., Schakowske, J., Blumenberg, L., Ruess, L., Scheu, S., Maraun, M., 2014. Freeliving nematodes as prey for higher trophic levels of forest soil food webs. Oikos 123, 1199-1211.

Heidemann, K., Scheu, S., Ruess, L., Maraun, M., 2011. Molecular detection of nematode predation and scavenging in oribatid mites: Laboratory and field experiments. Soil Biology and Biochemistry 43, 2229-2236. 
Hulot, F.D., Lacroix, G., Lescher-Moutoue, F., Loreau, M., 2000. Functional diversity governs ecosystem response to nutrient enrichment. Nature 405, 340-344.

Hutchinson, G.E., 1959. Homage to Santa Rosalia or why are there so many kinds of animals. American Natrualist 93, 145-159.

Huxel, McCann, 1998. Food web stability: the influence of trophic flows across habitats. The American Naturalist 152, 460.

Hyodo, F., Matsumoto, T., Takematsu, Y., Itioka, T., 2015. Dependence of diverse consumers on detritus in a tropical rain forest food web as revealed by radiocarbon analysis. Functional Ecology 29, 423-429.

Illig, J., Langel, R., Norton, R.A., Scheu, S., Maraun, M., 2005. Where are the decomposers? Uncovering the soil food web of a tropical montane rain forest in southern Ecuador using stable isotopes $\left({ }^{15} \mathrm{~N}\right)$. Journal of Tropical Ecology 21, 589-593.

Jackson, A.L., Inger, R., Parnell, A.C., Bearhop, S., 2011. Comparing isotopic niche widths among and within communities: SIBER - Stable Isotope Bayesian Ellipses in R. Journal of Animal Ecology 80, 595-602.

Kempson, D., Monte, L., Ghelardi, R., 1963. A new extractor for woodland litter. Pedobiologia 3, 1-21.

Klarner, B., Winkelmann, H., Krashevska, V., Maraun, M., Widyastuti, R., Scheu, S., 2017. Trophic niches, diversity and community composition of invertebrate top predators (Chilopoda) as affected by conversion of tropical lowland rainforest in Sumatra (Indonesia). PLOS ONE 1-17.

Korotkevich, A.Y., Potapov, A.M., Tiunov, A.V., Kuznetsova, N. a., 2018. Collapse of trophic-niche structure in belowground communities under anthropogenic disturbance. Ecosphere 9.

Kraft, N.J.B., Adler, P.B., Godoy, O., James, E.C., Fuller, S., Levine, J.M., 2015. Community assembly, coexistence and the environmental filtering metaphor. Functional Ecology 29, 592-599.

Krashevska, V., Sandmann, D., Marian, F., Maraun, M., Scheu, S., 2017. Leaf litter chemistry drives the structure and composition of soil testate amoeba communities in a tropical montane rainforest of the Ecuadorian Andes. Microbial Ecology 74, 681-690.

Lagerlöf, J., Maribie, C., John, J.M., 2017. Trophic interactions among soil arthropods in contrasting landuse systems in Kenya, studied with stable isotopes. European Journal of Soil Biology 79, 31-39.

Laliberté, E., Legendre, P., 2010. A distance-based framework for measuring functional diversity from multiple traits. Ecology 91, 299-305.

Langel, R., Dyckmans, J., 2014. Combined ${ }^{13} \mathrm{C}$ and ${ }^{15} \mathrm{~N}$ isotope analysis on small samples using a nearconventional elemental analyzer/isotope ratio mass spectrometer setup. Rapid Communications in Mass Spectrometry 28, 1019-1022.

Layman, C.A., Arrington, A.D., Montaña, C.G., Post, D.M., 2007. Can stable isotope ratios provide for community - Wide measures of trophic structure. Ecological Society of America 88, 42-48.

Lebrun, P., 1971. Écologie et biocénotique de quelques peuplements d'arthropodes édaphiques. Institut royal des sciences naturelles de Belgique.

Macarthur, R., Levins, R., Naturalist, T.A., Oct, N.S., Macarthur, R., Levins, R., 1967. The limiting similarity hypothesis. The American Naturalist 101, 377-385. 
Maraun, M., Erdmann, G., Fischer, B.M., Pollierer, M.M., Norton, R.A., Schneider, K., Scheu, S., 2011. Stable isotopes revisited: Their use and limits for oribatid mite trophic ecology. Soil Biology and Biochemistry 43, 877-882.

Maraun, M., Schatz, H., Scheu, S., 2007. Awesome or ordinary? Global diversity patterns of oribatid mites. Ecography 30, 209-216.

Maraun, M., Scheu, S., 2000. The structure of oribatid mite communities (Acari, Oribatida): Patterns, mechanisms and implications for future research. Source: Ecography 23, 374-383.

Margono, B.A., Potapov, P. V., Turubanova, S., Stolle, F., Hansen, M.C., 2014. Primary forest cover loss in Indonesia over 2000-2012. Nature Climate Change 4, 730-735.

Mason, N.W.H., Mouillot, D., Lee, W.G., Wilson, J.B., 2005. Functional richness, functional evenness and functional divergence: The primary components of functional diversity. Oikos 111, 112-118.

Meijide, A., Badu, C.S., Moyano, F., Tiralla, N., Gunawan, D., Knohl, A., 2018. Impact of forest conversion to oil palm and rubber plantations on microclimate and the role of the 2015 ENSO event. Agricultural and Forest Meteorology 252, 208-2019.

Minor, M.A., Ermilov, S.G., Tiunov, A.V., 2017. Taxonomic resolution and functional traits in the analysis of tropical oribatid mite assemblages. Experimental and Applied Acarology 73, 365-381.

Myers, N., Mittermeier, R.A., Mittermeier, C.G., da Fonseca, G.A., Kent, J., 2000. Biodiversity hotspots for conservation priorities. Nature 403, 853-8.

Newsome, S.D., Martinez del Rio, C., Bearhop, S., Phillips, D.L., 2007. A niche for stable isotope ecology. Frontiers in Ecology and the Environment 5, 429-436.

Norton, R.A., Behan-Pelletier, V.M., 1991. Calcium carbonate and calcium oxalate as cuticular hardening agents in oribatid mites (Acari: Oribatida). Canadian Journal of Zoology 69, 1504-1511.

Pachl, P., Domes, K., Schulz, G., Norton, R.A., Scheu, S., Schaefer, I., Maraun, M., 2012. Convergent evolution of defense mechanisms in oribatid mites (Acari, Oribatida) shows no "ghosts of predation past". Molecular Phylogenetics and Evolution 412-20.

Pearson, T.H., 2001. Functional group ecology in soft-sediment marine benthos: The role of bioturbation. Oceanogr. Mar. Biol. 39, 233-267.

Petchey, O.L., 2003. Integrating methods that investigate how complementarity influences ecosystem functioning. Oikos 101, 323-330.

Pollierer, M.M., Langel, R., Scheu, S., Maraun, M., 2009. Compartmentalization of the soil animal food web as indicated by dual analysis of stable isotope ratios $\left({ }^{15} \mathrm{~N} /{ }^{14} \mathrm{~N}\right.$ and $\left.{ }^{13} \mathrm{C} /{ }^{12} \mathrm{C}\right)$. Soil Biology and Biochemistry 41, 1221-1226.

Post, D.M., 2002. Using stable isotopes to estimate trophic position: Models, methos, and assumptions. Ecology 83, 703-718.

Potapov, A.M., Klarner, B., Sandmann, D., Widyastuti, R., Scheu, S., 2019a. Linking size spectrum, energy flux and trophic multifunctionality in soil food webs of tropical land-use systems. Journal of Animal Ecology 1-15. 
Potapov, A.M., Semenina, E.E., Kurakov, A.V., Tiunov, A.V., 2013. Large ${ }^{13} \mathrm{C} /{ }^{12} \mathrm{C}$ and small ${ }^{15} \mathrm{~N} /{ }^{14} \mathrm{~N}$ isotope fractionation in an experimental detrital foodweb (litter-fungi-collembolans). Ecological Research 28 , 1069-1079.

Potapov, A.M., Tiunov, A.V., Scheu, S., 2019b. Uncovering trophic positions and food resources of soil animlas using bulk natural stable isotope composition. Biological Reviews 94, 37-59.

R Core Team, 2018. R: A language and environment for statistical computing. R Foundation for Statistical Computing,.

Rembold, K., Mangopo, H., Tjitrosoedirdjo, S.S., Kreft, H., 2017. Plant diversity, forest dependency, and alien plant invasions in tropical agricultural landscapes. Biological Conservation 213, 234-242.

Salles, J.F., Poly, F., Schmid, B., Roux, X.L., 2009. Community niche predicts the functioning of denitrifying bacterial assemblages. Ecology 90, 3324-3332.

Scheu, S., Falca, M., 2000. The soil food web of two beech forests (Fagus sylvatica) of contrasting humus type: Stable isotope analysis of a macro- and a mesofauna-dominated community. Oecologia 123, 285-296.

Schneider, K., Migge, S., Norton, R.A., Scheu, S., Langel, R., Reineking, A., Maraun, M., 2004. Trophic niche differentiation in soil microarthropods (Oribatida, Acari): Evidence from stable isotope $\operatorname{ratios}\left({ }^{15} \mathrm{~N} /{ }^{14} \mathrm{~N}\right)$. Soil Biology and Biochemistry 36, 1769-1774.

Schulz, G., Schneider, D., Brinkmann, N., Edy, N., Daniel, R., Polle, A., Scheu, S., Krashevska, V., 2019. Changes in trophic groups of protists with conversion of rainforest into rubber and oil palm plantations. Frontiers in Microbiology 10, 1-14.

Sodhi, N.S., Posa, M.R.C., Lee, T.M., Bickford, D., Koh, L.P., Brook, B.W., 2010. The state and conservation of Southeast Asian biodiversity. Biodiversity and Conservation 19, 317-328.

Spence, K.O., Rosenheim, J.A., 2005. Isotopic enrichment in herbivorous insects: A comparative field-based study of variation. Oecologia 146, 89-97.

Susanti, W.I., Pollierer, M.M., Widyastuti, R., Scheu, S., Potapov, A., 2019. Conversion of rainforest to oil palm and rubber plantations alters energy channels in soil food webs. Ecology and Evolution 1-13.

Tilman, D., 2004. Niche tradeoffs, neutrality, and community structure: A stochastic theory of resource competition, invasion, and community assembly. Proceedings of the National Academy of Sciences of the United States of America 101, 10854-10861.

Tilman, D., 2001. Functional diversity. Encyclopedia of Biodiversit 3, 109-120.

Tiunov, A. V., 2007. Stable isotopes of carbon and nitrogen in soil ecological studies. Biology Bulletin 34, 395-407.

Van der Merwe, N.J., Medina, E., 1991. The canopy effect, carbon isotope ratios and foodwebs in Amazonia. Journal of Archaeological Science 18, 249-259.

Vanderklift, M.A., Ponsard, S., 2003. Sources of variation in consumer-diet $\delta^{15} \mathrm{~N}$ enrichment: A metaanalysis. Oecologia 136, 169-182.

Vellend, M., 2010. Conceptual synthesis in community ecology. The Quarterly Review of Biology 85, 183206. 
Villéger, S., Mason, N.W.H., Mouillot, D., 2008. New multidimensional functional diversity indices for a multifaceted framework in functional ecology. Ecology 89, 2290-2301.

Violle, C., Nemergut, D.R., Pu, Z., Jiang, L., 2011. Phylogenetic limiting similarity and competitive exclusion. Ecology Letters 14, 782-787.

Wada, E., Mizutani, H., Minagawa, M., 1991. The use of stable isotopes for food web analysis. Critical Reviews in Food Science and Nutrition 30(4), 361-371.

Wickham, H., 2016. ggplot2: Elegant Graphics for Data Analysis. Springer.

Wilcove, D.S., Giam, X., Edwards, D.P., Fisher, B., Koh, L.P., 2013. Navjot's nightmare revisited: Logging, agriculture, and biodiversity in Southeast Asia. Trends in Ecology and Evolution 28, 531-540.

Wilcove, D.S., Koh, L.P., 2010. Addressing the threats to biodiversity from oil-palm agriculture. Biodiversity and Conservation 19, 999-1007.

Yoneyama, T., Handley, L.L., Scrimgeour, C.M., Fisher, D.B., Raven, J.A., 1997. Variations of the natural abundances of nitrogen and carbon isotopes in Triticum aestivum, with special reference to phloem and xylem exudates. New Phytologist 137, 205-213. 


\section{Appendix}

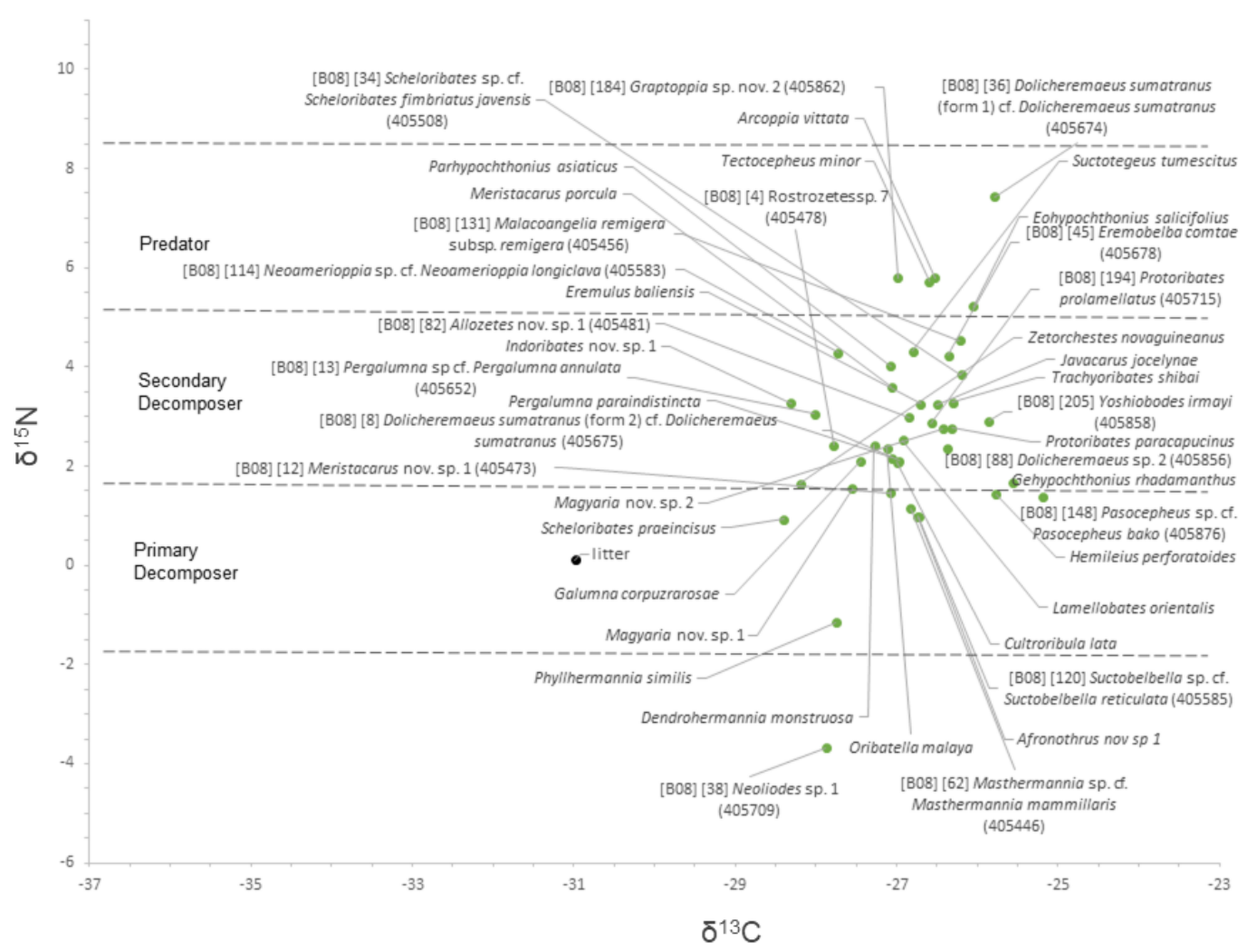

Figure S1a: Mean stable isotope values of oribatid mite species of the four land-use systems studied: rainforest (a), jungle rubber (b), rubber (c) and oil palm (d). The average stable isotope value of litter used for calibration (see Methods) is given as reference. Dashed horizontal lines reflect boundaries of trophic levels (primary decomposers, secondary decomposers and predators; see Methods). For statistical analysis see text. 


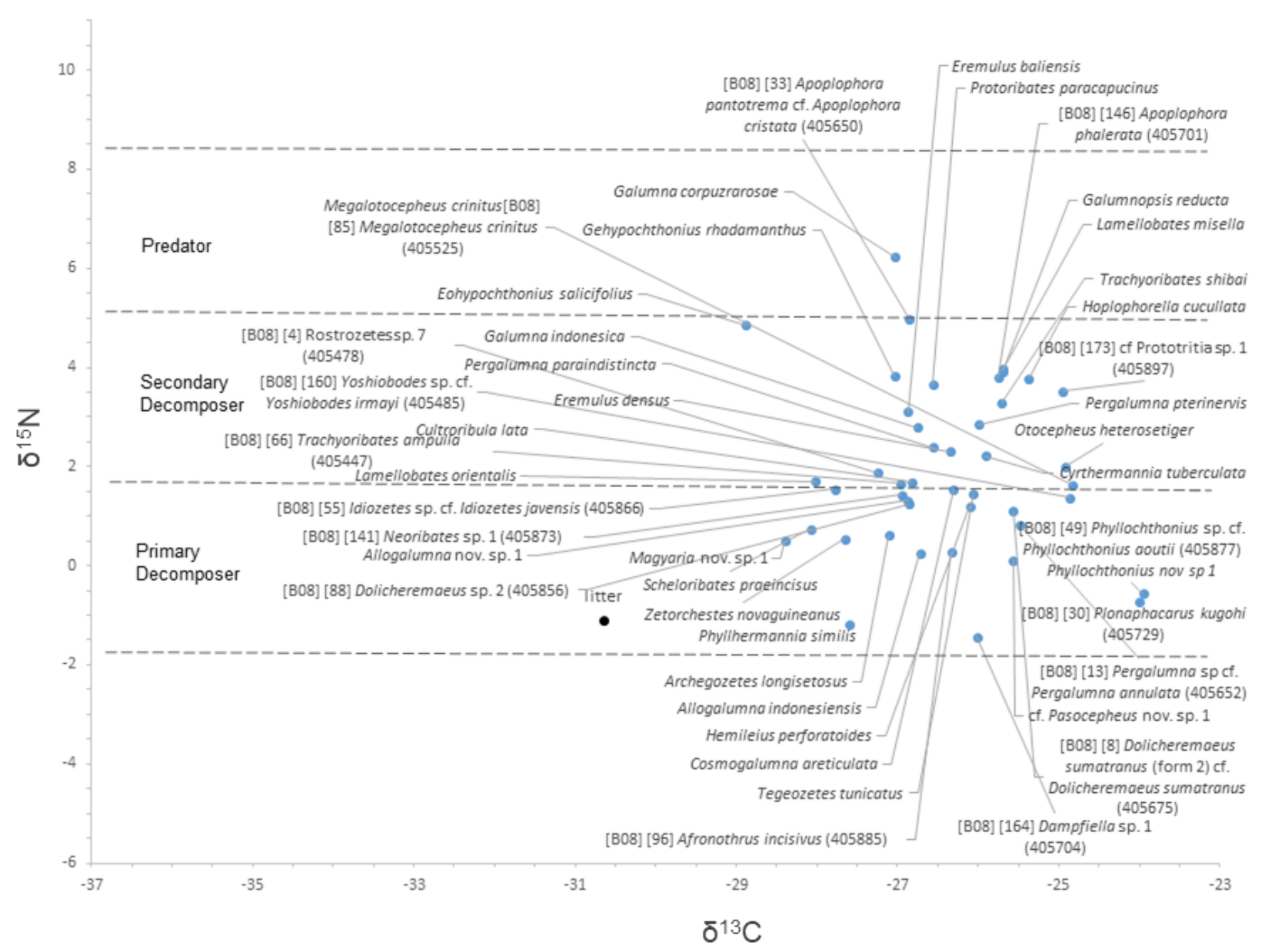

Figure S1b: Mean stable isotope values of oribatid mite species of the four land-use systems studied: rainforest (a), jungle rubber (b), rubber (c) and oil palm (d). The average stable isotope value of litter used for calibration (see Methods) is given as reference. Dashed horizontal lines reflect boundaries of trophic levels (primary decomposers, secondary decomposers and predators; see Methods). For statistical analysis see text. 


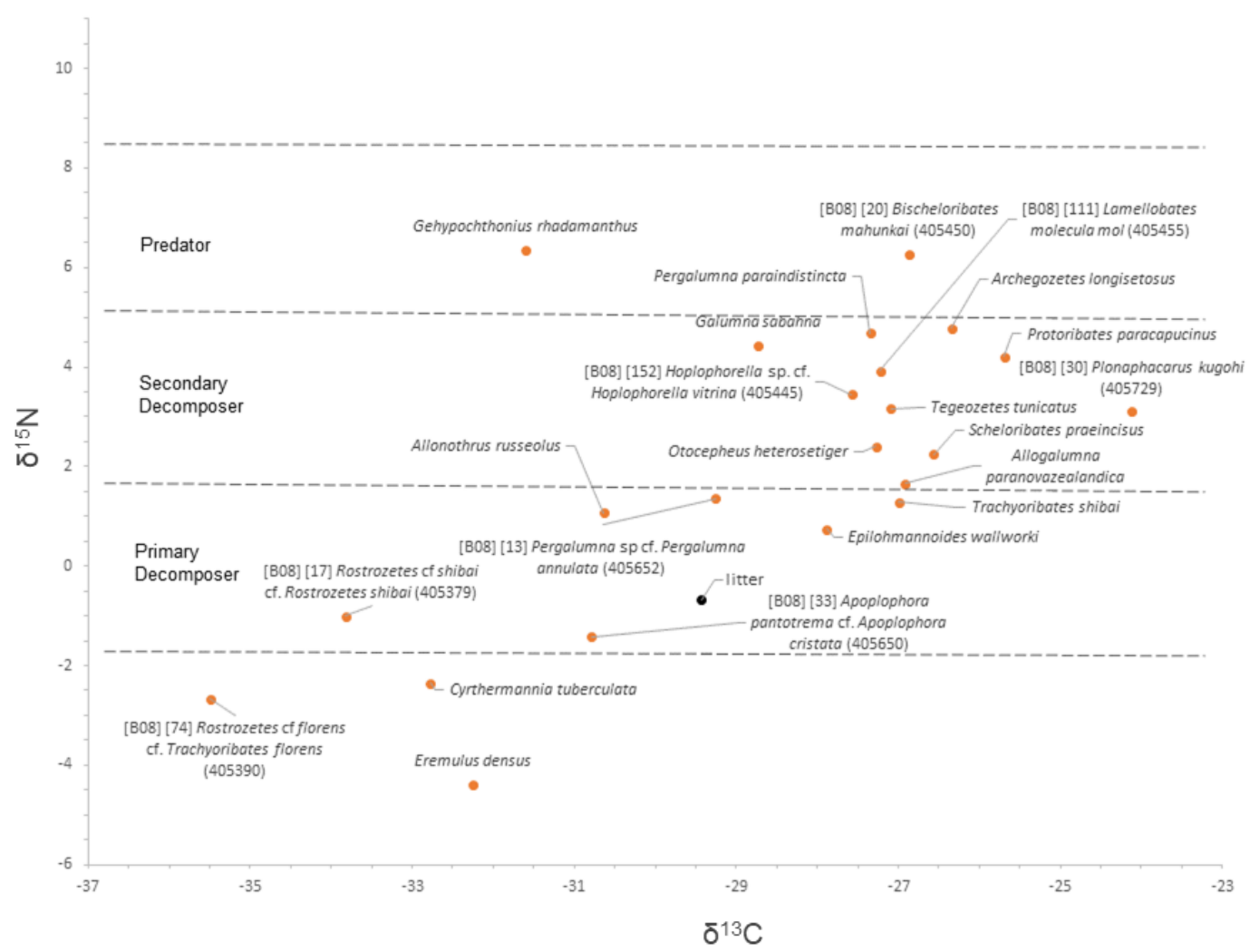

Figure S1c: Mean stable isotope values of oribatid mite species of the four land-use systems studied: rainforest (a), jungle rubber (b), rubber (c) and oil palm (d). The average stable isotope value of litter used for calibration (see Methods) is given as reference. Dashed horizontal lines reflect boundaries of trophic levels (primary decomposers, secondary decomposers and predators; see Methods). For statistical analysis see text. 


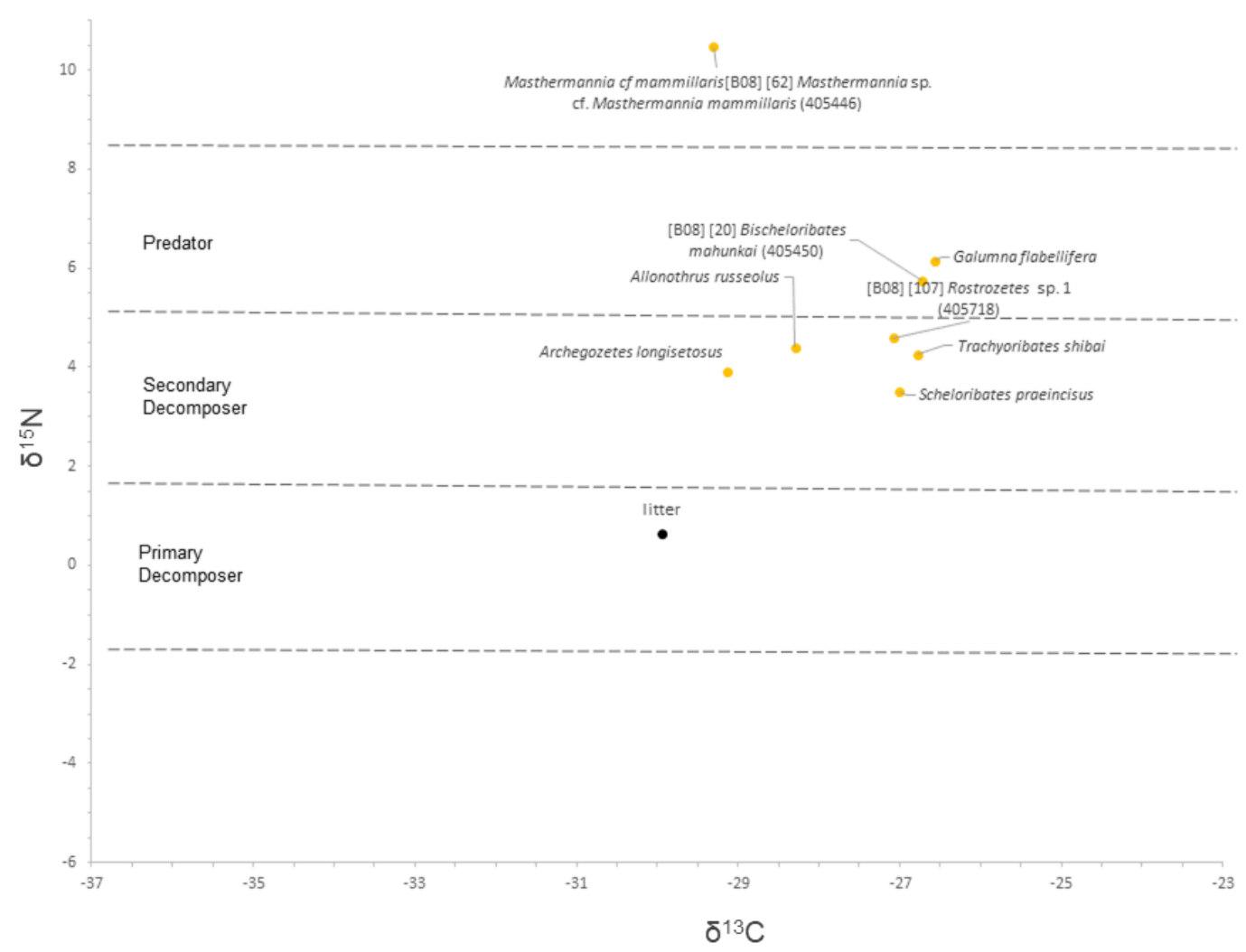

Figure S1d: Mean stable isotope values of oribatid mite species of the four land-use systems studied: rainforest (a), jungle rubber (b), rubber (c) and oil palm (d). The average stable isotope value of litter used for calibration (see Methods) is given as reference. Dashed horizontal lines reflect boundaries of trophic levels (primary decomposers, secondary decomposers and predators; see Methods). For statistical analysis see text. 

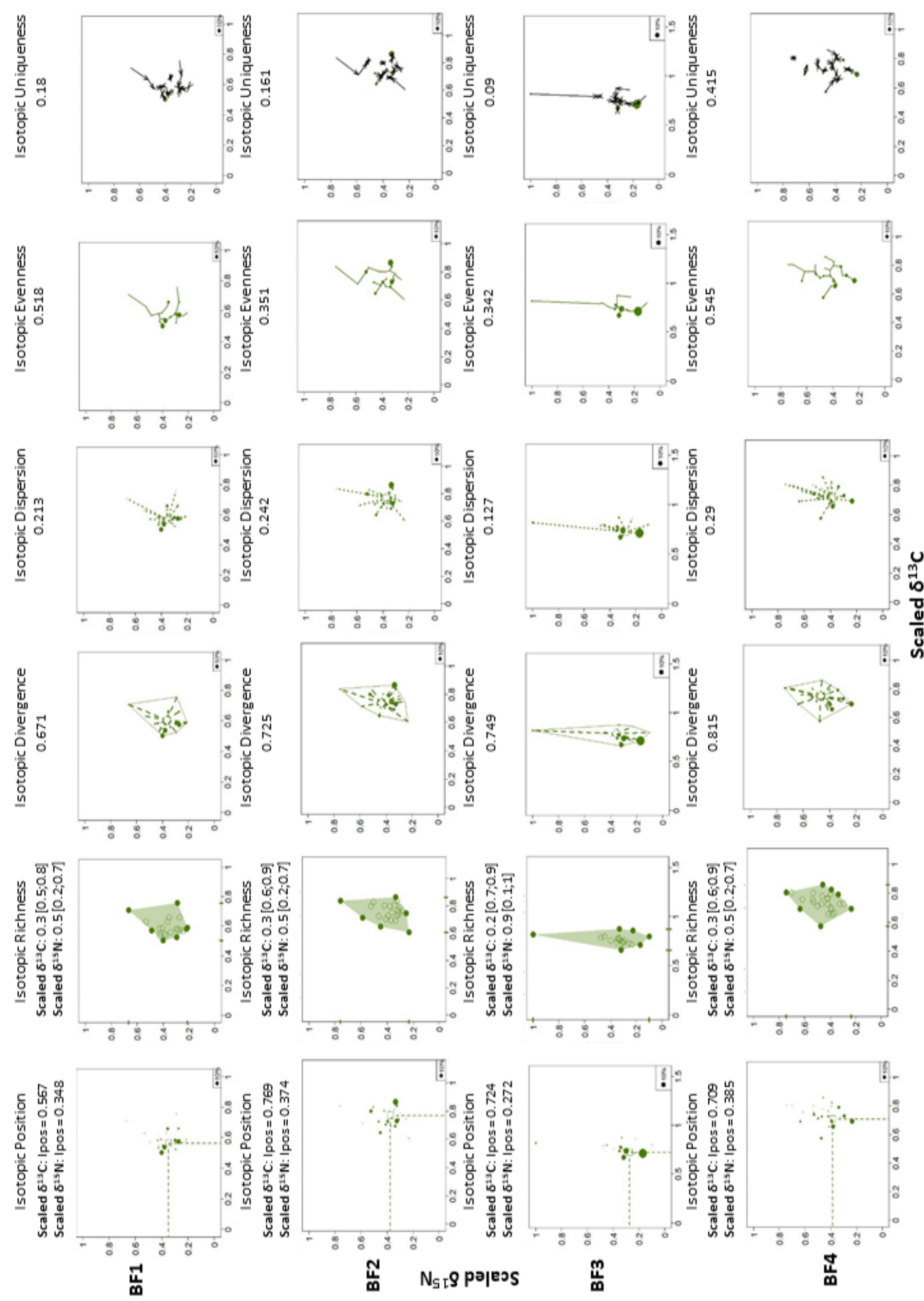

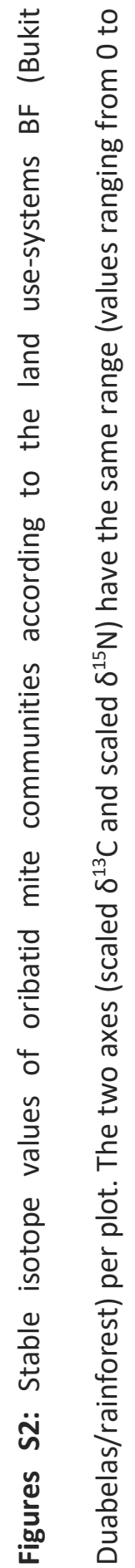

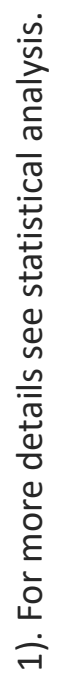



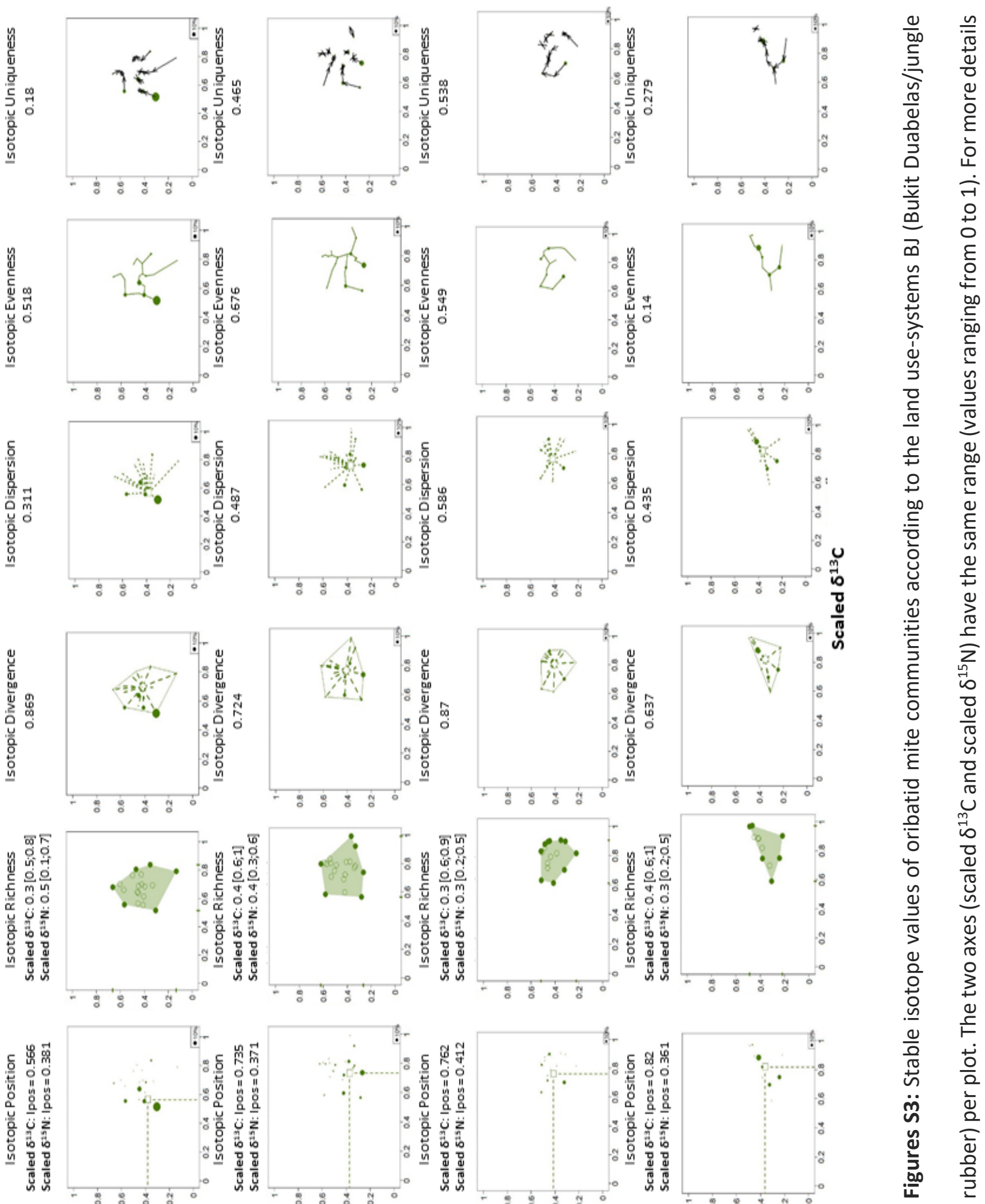

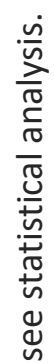



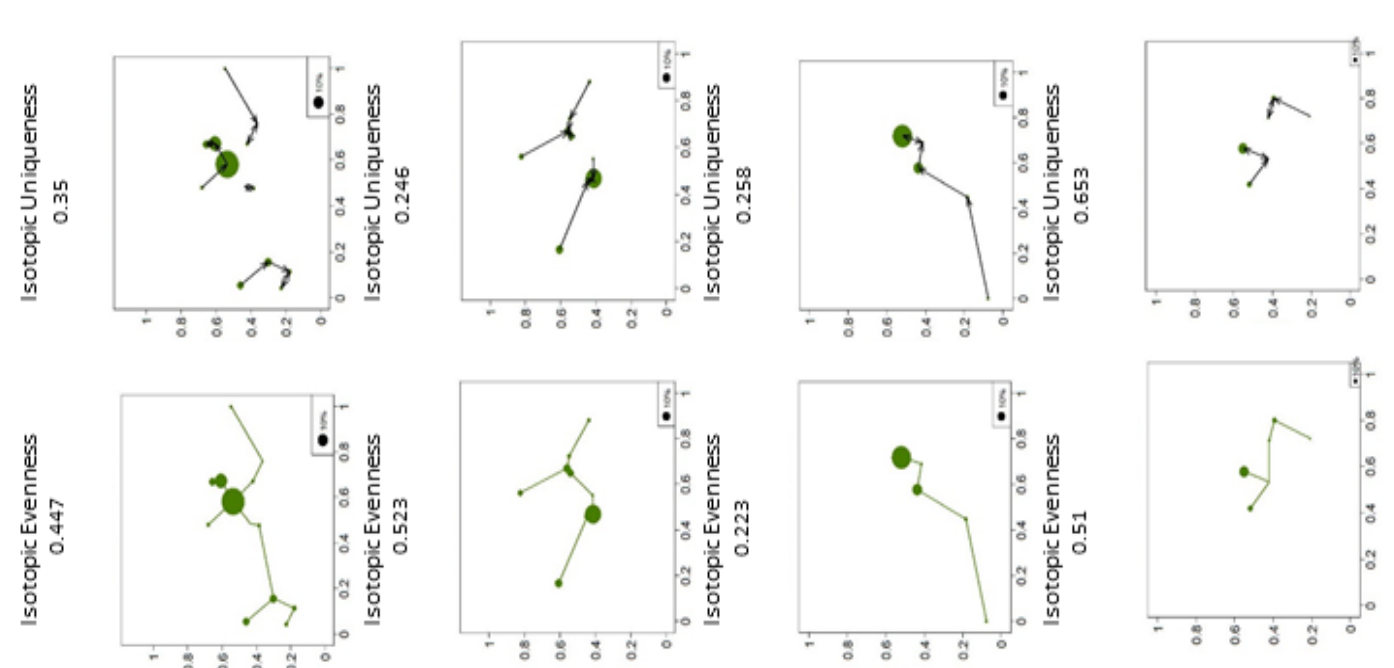

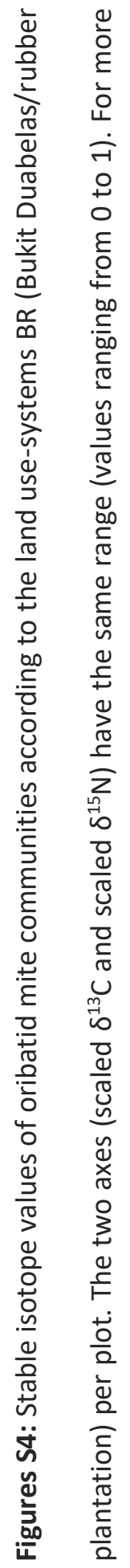

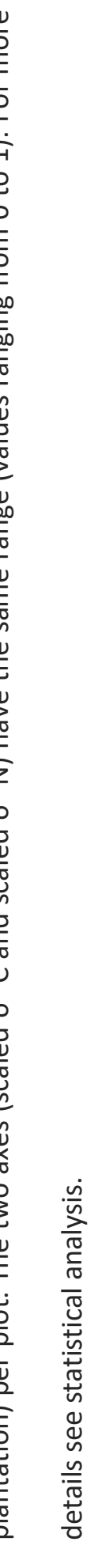
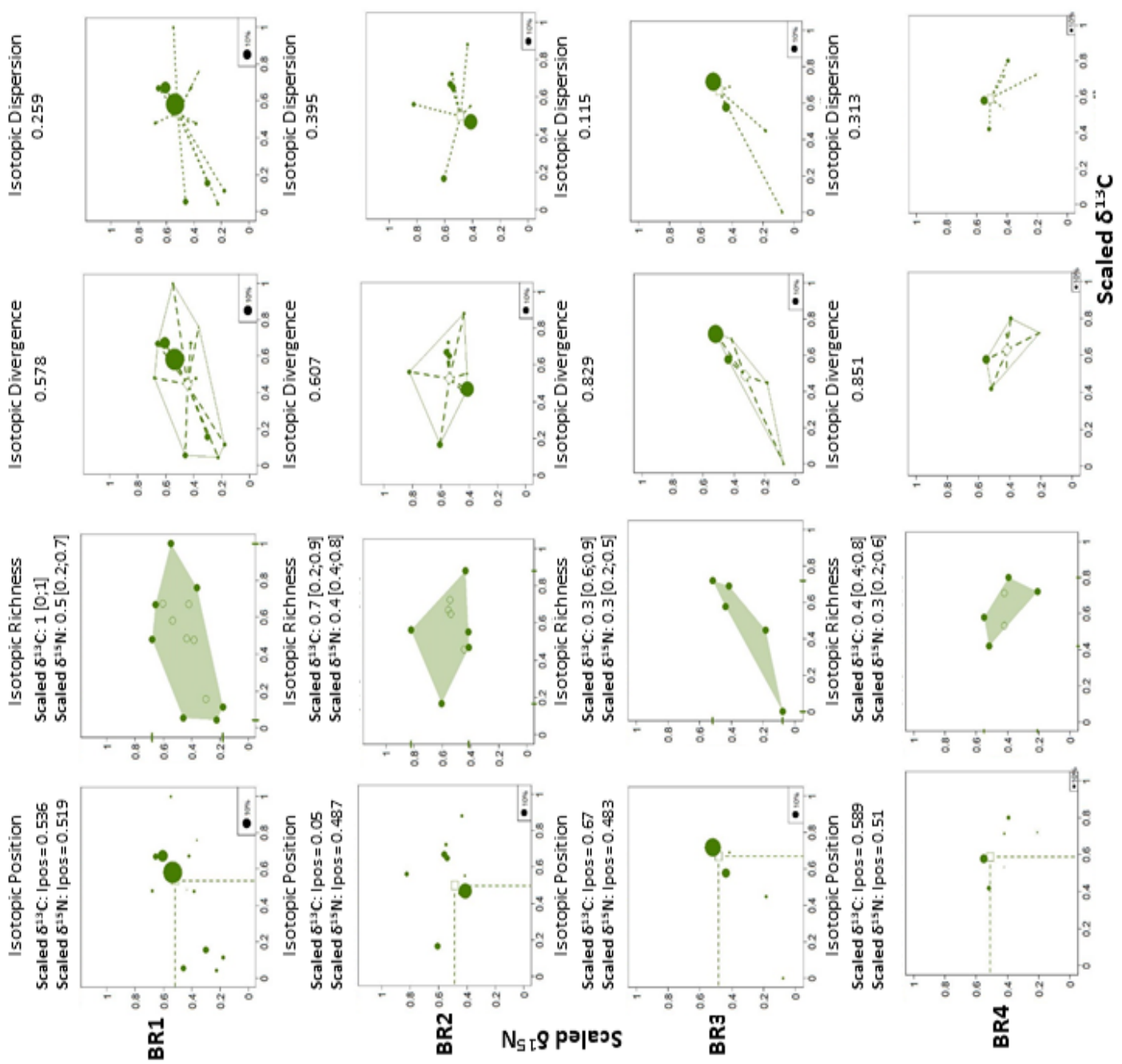

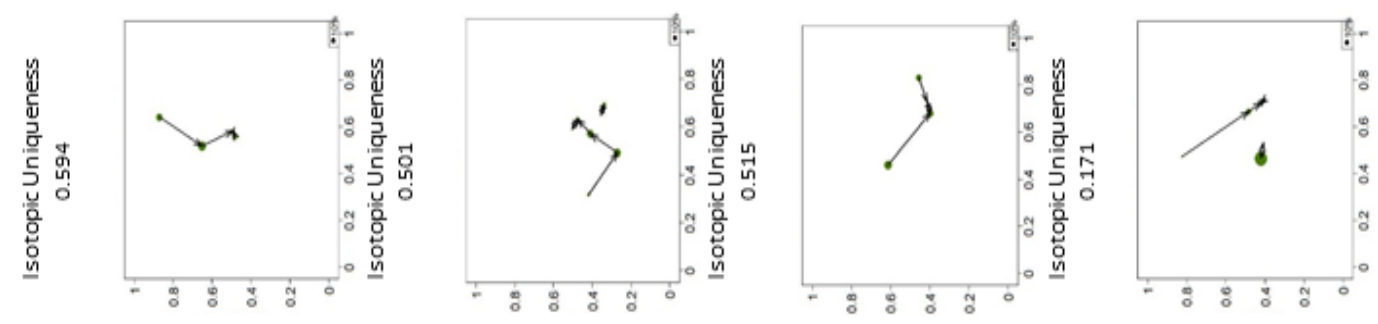

$\frac{\varepsilon}{\pi}$
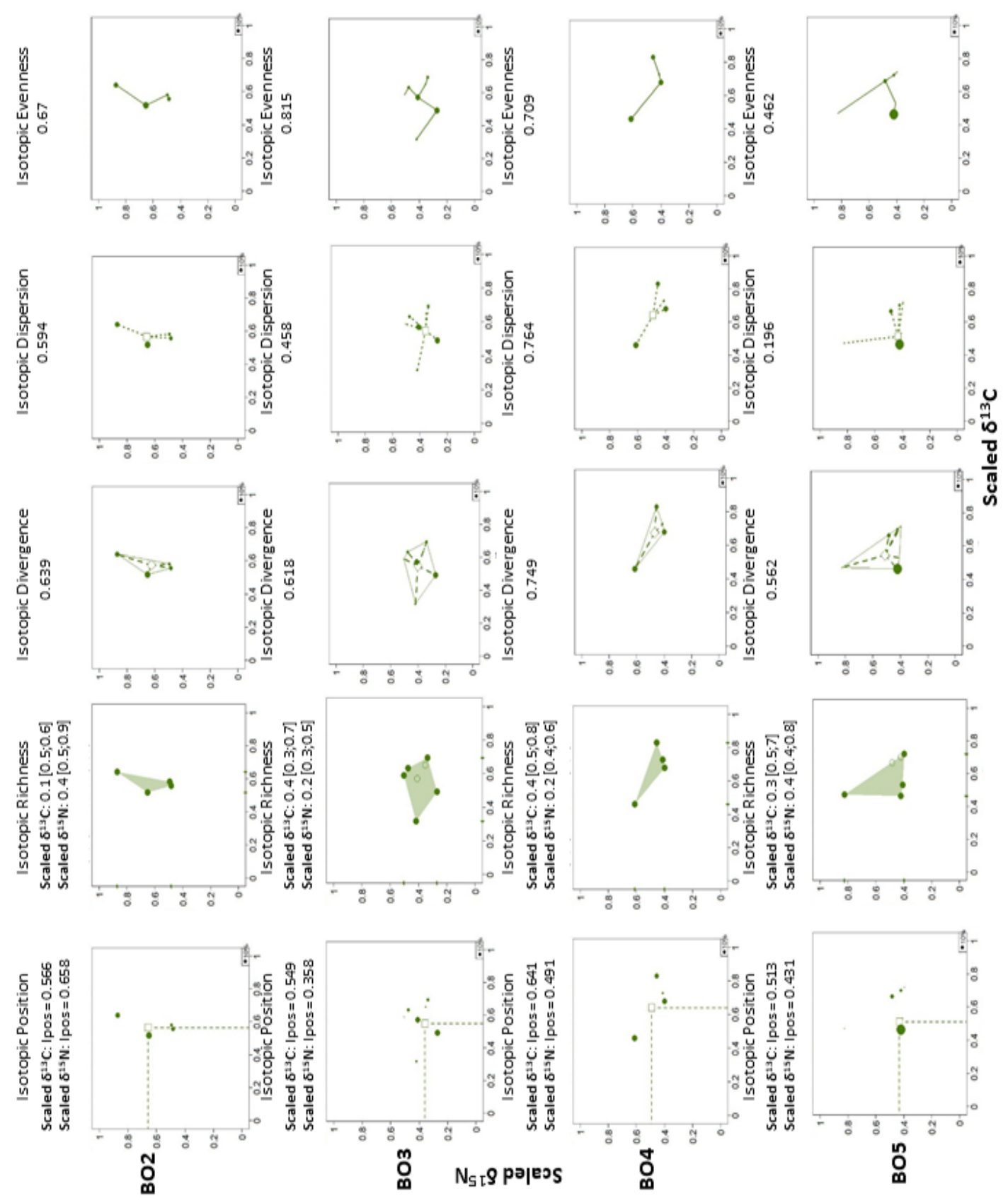

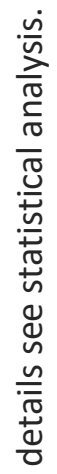



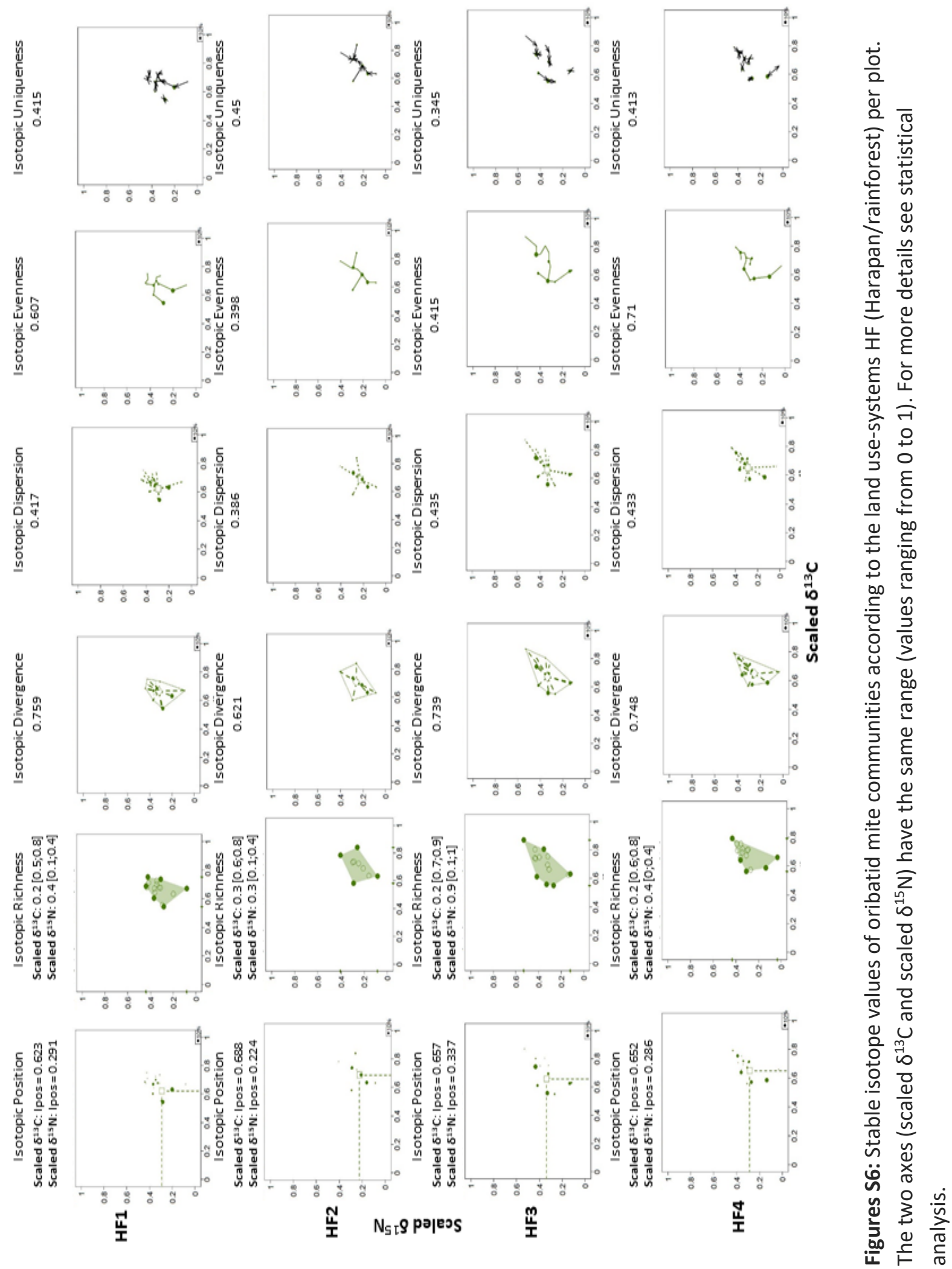

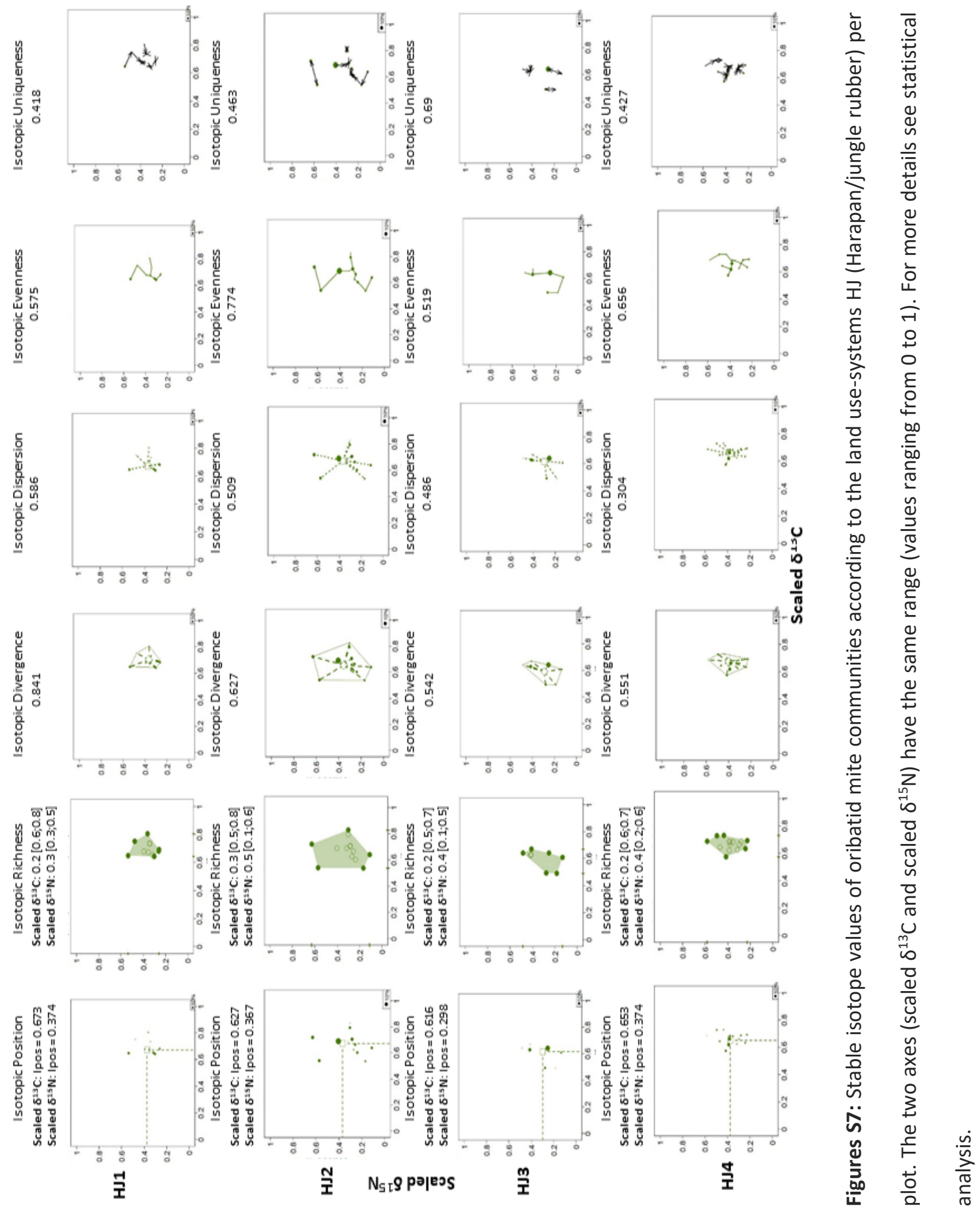

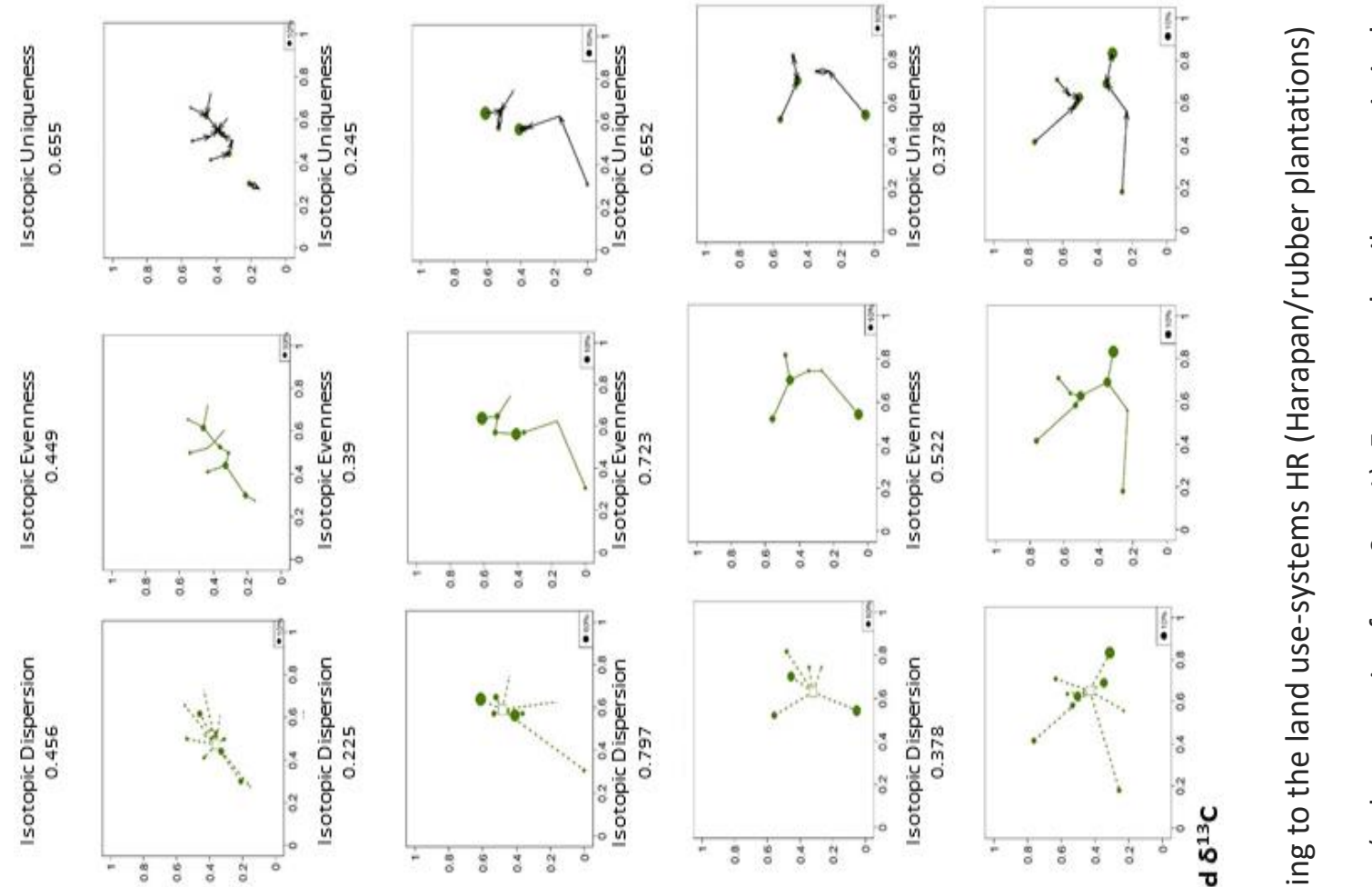

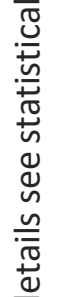
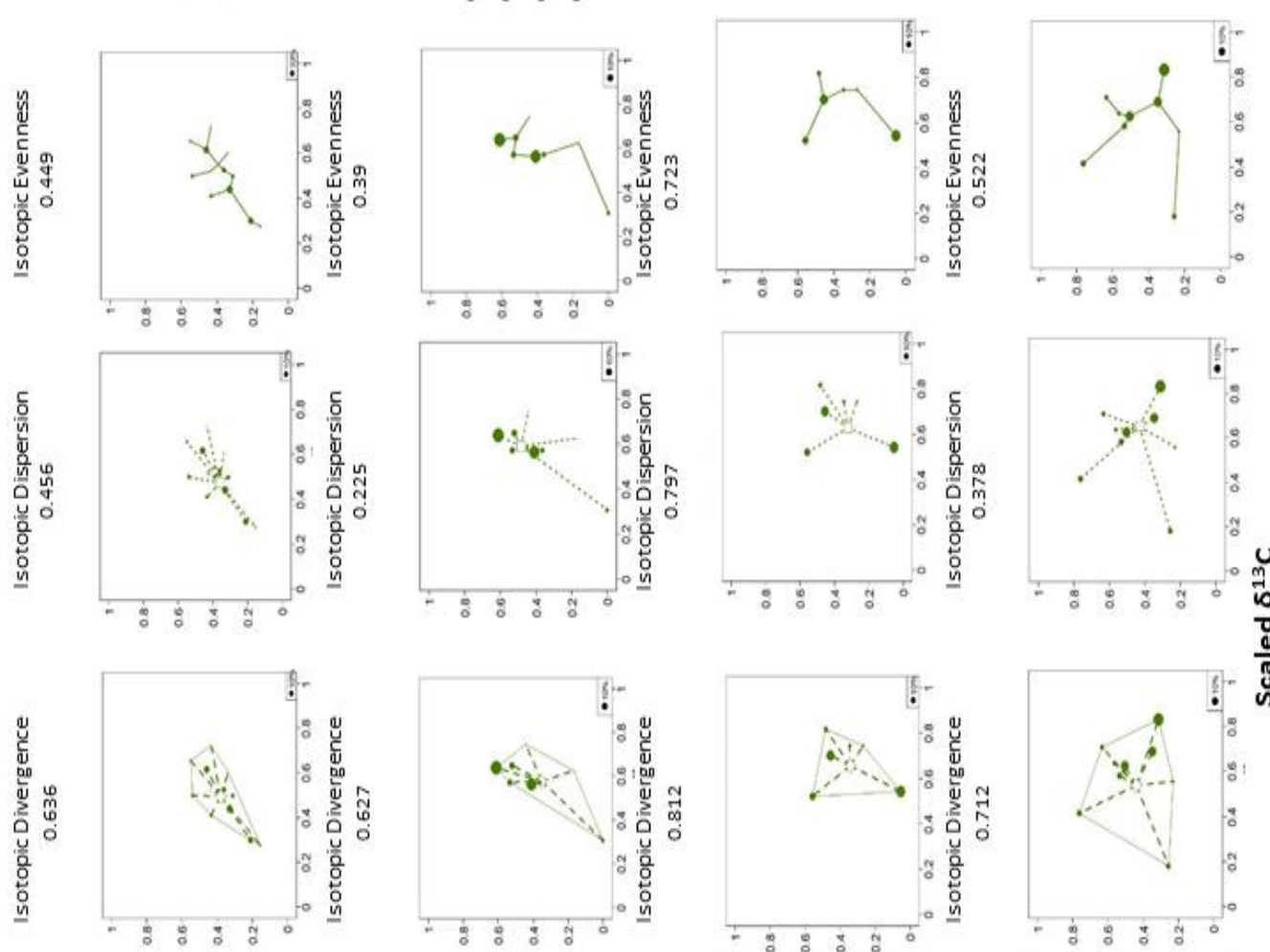

ํำ
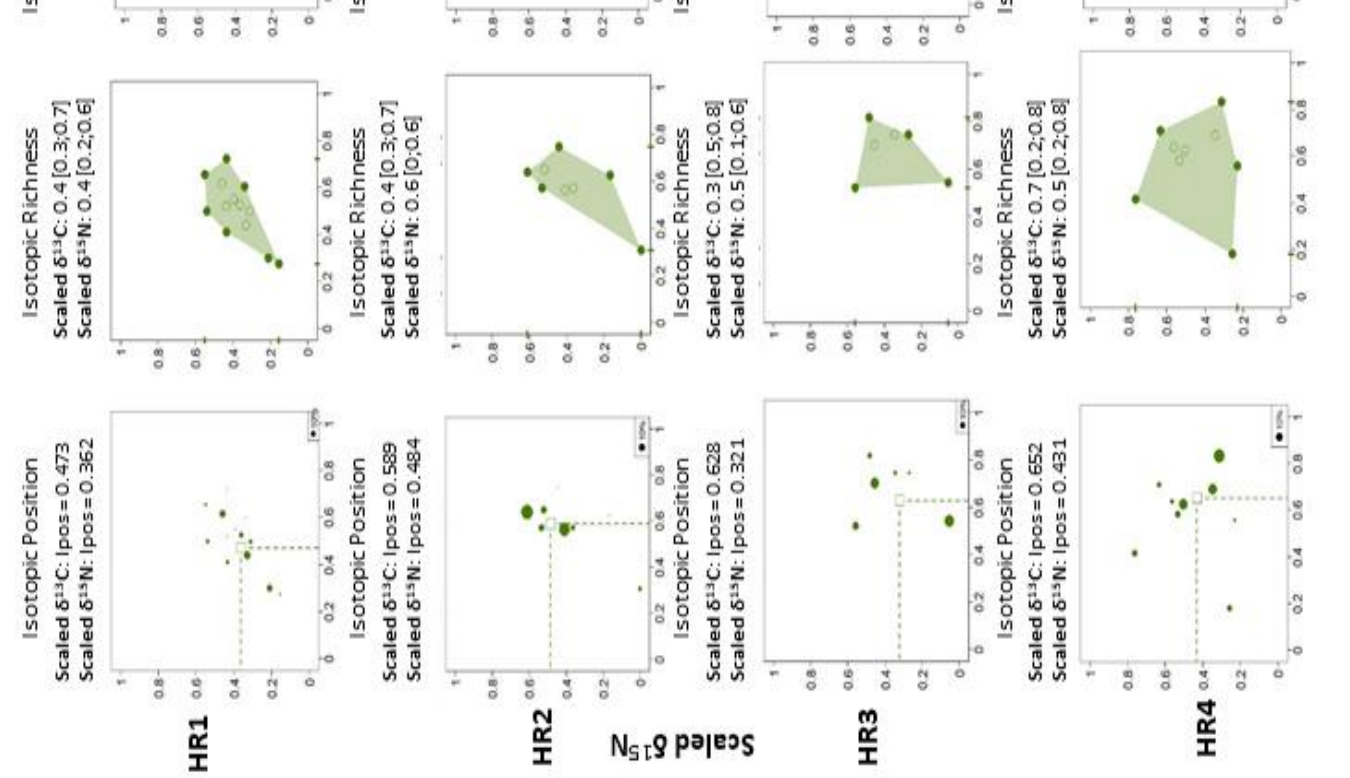

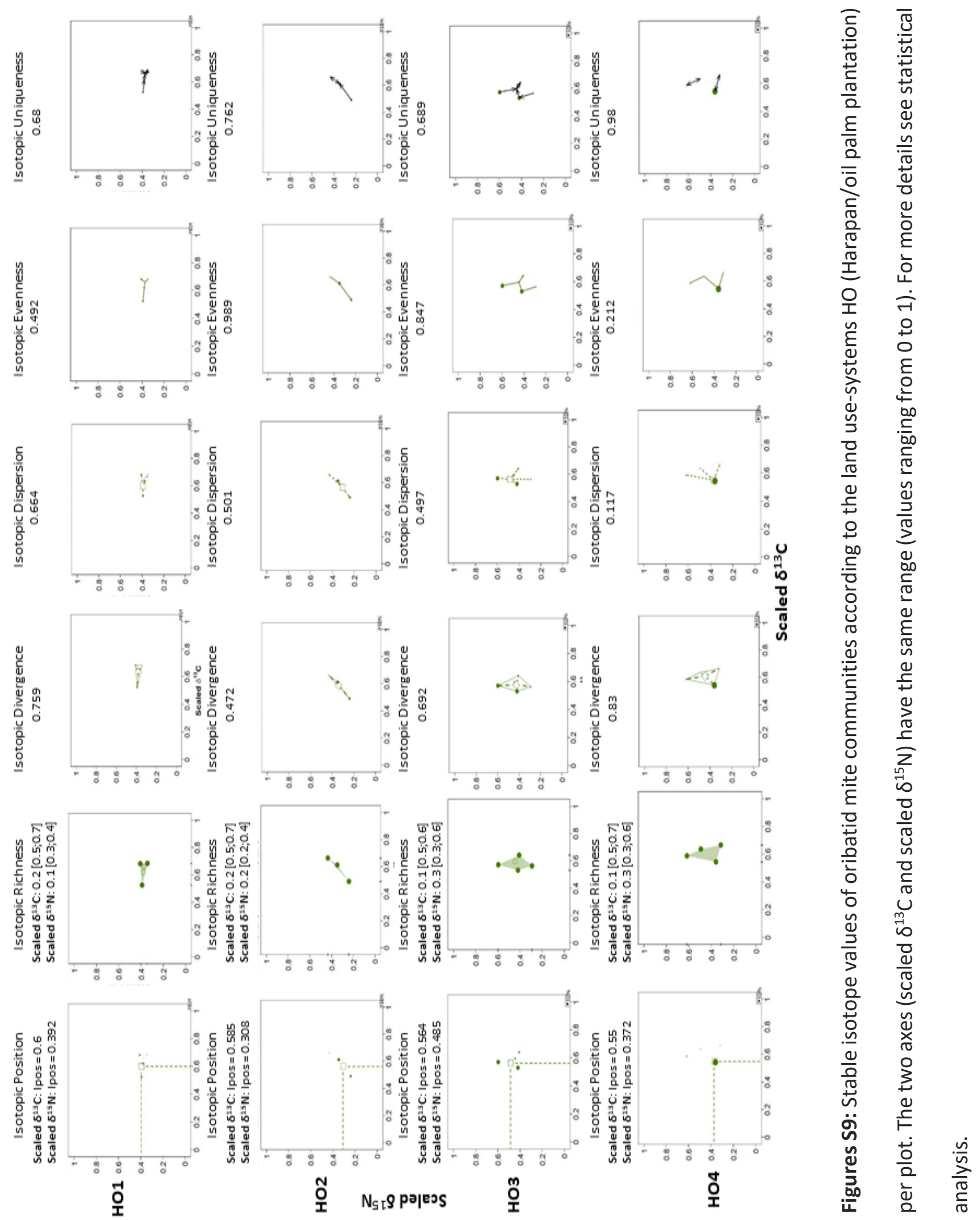
Table S1: Absolute and calibrated (see methods) stable isotope values of oribatid mite individuals studied. Species ID in Ecotaxonomy database (http://ecotaxonomy.org/), sample, species name, author, landscape, land-use system, absolute values of $\delta^{15} \mathrm{~N}$ and $\delta^{13} \mathrm{C}$ values, biomass per species percentage and $\Delta^{15} \mathrm{~N}$ and $\Delta^{13} \mathrm{C}$ per community (weighted values accordingly to the percentage of species per plot).

\begin{tabular}{|c|c|c|c|c|c|c|c|c|c|c|}
\hline \multirow[t]{3}{*}{ sample } & \multirow{3}{*}{$\begin{array}{l}\text { species } \\
\text { ID }\end{array}$} & \multirow[t]{3}{*}{ species } & \multirow[t]{3}{*}{ author } & \multicolumn{2}{|c|}{ absolute } & \multicolumn{2}{|c|}{ litter-calibrated } & \multirow{3}{*}{$\begin{array}{l}\text { Biomass } \\
\text { species } \\
\%\end{array}$} & \multicolumn{2}{|c|}{ community } \\
\hline & & & & $\delta 13 C$ & $\delta 15 N$ & mean & mean & & $\Delta 15 N$ & $\Delta 13 C$ \\
\hline & & & & & & $\delta 15 N$ & $\delta 13 C$ & & & \\
\hline \multicolumn{11}{|c|}{$\begin{array}{l}\text { Bukit Duabelas } \\
\text { rainforest }\end{array}$} \\
\hline BF1 & 405583 & $\begin{array}{l}\text { [B08] [114] Neoamerioppia } \\
\text { sp. cf. Neoamerioppia } \\
\text { longiclava (405583) }\end{array}$ & & -27.30 & 4.03 & 0.47 & -28.72 & 0.02 & 0.10 & -0.67 \\
\hline BF2 & & & & -28.75 & 4.22 & 0.02 & -31.81 & 0.08 & 0.34 & -2.32 \\
\hline BF3 & & & & -27.32 & 1.40 & 0.53 & -31.67 & 0.17 & 0.24 & -4.70 \\
\hline BF4 & & & & -27.56 & 7.53 & -0.67 & -31.29 & 0.04 & 0.33 & -1.22 \\
\hline BF2 & & & & -27.62 & 4.46 & 0.02 & -31.81 & 0.03 & 0.14 & -0.84 \\
\hline BF4 & 405652 & $\begin{array}{l}\text { [B08] [13] Pergalumna sp cf. } \\
\text { Pergalumna annulata } \\
\text { (405652) }\end{array}$ & $\begin{array}{l}\text { Mahunka, } \\
\text { S., } 1973\end{array}$ & -27.05 & 3.93 & -0.67 & -31.29 & 0.04 & 0.15 & -1.02 \\
\hline BF1 & 405456 & $\begin{array}{l}\text { [B08] [131] Malacoangelia } \\
\text { remigera subsp. remigera } \\
\text { (405456) }\end{array}$ & & -25.91 & 6.36 & 0.47 & -28.72 & 0.01 & 0.08 & -0.32 \\
\hline BF2 & & & & -26.53 & 2.69 & 0.02 & -31.81 & 0.00 & 0.01 & -0.10 \\
\hline BF4 & 405876 & $\begin{array}{l}\text { [B08] [148] Pasocepheus sp. } \\
\text { cf. Pasocepheus bako } \\
(405876)\end{array}$ & & -25.39 & 1.90 & -0.67 & -31.29 & $\# N / A$ & $\# N / A$ & $\# N / A$ \\
\hline BF2 & 405862 & $\begin{array}{l}\text { [B08] [184] Graptoppia sp. } \\
\text { nov. } 2 \text { (405862) }\end{array}$ & & -28.08 & 1.71 & 0.02 & -31.81 & 0.06 & 0.11 & -1.75 \\
\hline BF4 & & & & -25.90 & 9.87 & -0.67 & -31.29 & 0.00 & 0.00 & -0.01 \\
\hline BF4 & 405715 & $\begin{array}{l}\text { [B08] [194] Protoribates } \\
\text { prolamellatus (405715) }\end{array}$ & $\begin{array}{l}\text { Ermilov, } \\
\text { Sandmann } \\
\text { \& Scheu, } \\
2019\end{array}$ & -26.57 & 2.87 & -0.67 & -31.29 & 0.01 & 0.03 & -0.25 \\
\hline BF3 & 405858 & $\begin{array}{l}\text { [B08] [205] Yoshiobodes } \\
\text { irmayi (405858) }\end{array}$ & & -26.58 & 2.13 & 0.53 & -31.67 & 0.00 & 0.00 & -0.03 \\
\hline BF4 & & & & -25.14 & 3.70 & -0.67 & -31.29 & 0.02 & 0.06 & -0.39 \\
\hline BF1 & 405674 & $\begin{array}{l}\text { [B08] [36] Dolicheremaeus } \\
\text { sumatranus (form 1) cf. } \\
\text { Dolicheremaeus sumatranus } \\
\text { (405674) }\end{array}$ & & -25.46 & 2.54 & 0.47 & -28.72 & 0.09 & 0.22 & -2.24 \\
\hline BF2 & & & & -25.95 & 10.87 & 0.02 & -31.81 & 0.00 & 0.01 & -0.03 \\
\hline BF4 & & & & -25.95 & 8.91 & -0.67 & -31.29 & 0.01 & 0.05 & -0.15 \\
\hline BF3 & 405678 & $\begin{array}{l}\text { [B08] [45] Eremobelba } \\
\text { comtae (405678) }\end{array}$ & & -26.44 & 4.64 & 0.53 & -31.67 & 0.01 & 0.05 & -0.26 \\
\hline BF4 & & & & -26.27 & 3.82 & -0.67 & -31.29 & 0.00 & 0.00 & 0.00 \\
\hline BF1 & 405868 & $\begin{array}{l}\text { [B08] [47] Haplozetes } \\
\text { bayartogtokhi (405868) }\end{array}$ & $\begin{array}{l}\text { Ermilov, } \\
\text { Sandmann } \\
\text { \& Scheu, } \\
2019\end{array}$ & -26.79 & 0.16 & 0.47 & -28.72 & 0.01 & 0.00 & -0.36 \\
\hline BF2 & & & & -26.08 & 5.34 & 0.02 & -31.81 & 0.02 & 0.08 & -0.40 \\
\hline BF1 & 405446 & $\begin{array}{l}\text { [B08] [62] Masthermannia } \\
\text { sp. cf. Masthermannia } \\
\text { mammillaris (405446) }\end{array}$ & & -26.68 & 1.11 & 0.47 & -28.72 & 0.01 & 0.02 & -0.37 \\
\hline
\end{tabular}


BF2

$\mathrm{BF} 3$

BF4

BF1

BF2

BF3 $405856 \quad$ [B08] [88] Dolicheremaeus

BF4

BF1

BF2

BF4

BF2

BF1

BF3

BF4

BF1

BF2

$\mathrm{BF} 1$

BF3

BF4

BF1

BF4

BF2

BF1

BF2

$\mathrm{BF}$

BF4

BF3

BF4

BF3

BF4

BF

BF2

$\mathrm{BF3}$

$\mathrm{BF} 4$

BF1

BF2

$\mathrm{BF3}$

BF4

BF1

BF2

$\mathrm{BF3}$

BF4

BF3
405481 [B08] [82] Allozetes nov. sp. 1 (405481)

$$
\text { sp. } 2 \text { (405856) }
$$

405885 [B08] [96] Afronothrus incisivus (405885)

\section{Arcoppia vittata}

405384 Dendrohermannia monstruosa

$405618 \quad$ Eohypochthonius salicifolius

405618 Eohypochthonius salicifolius

405626 Eremulus baliensis

405547 Galumna corpuzrarosae
$405471 \quad$ Indoribates hauseri

$405530 \quad$ Lamellobates orientalis

405472 Magyaria leonilae

405578 Meristacarus porcula

405439 Oribatella malaya

$\begin{array}{lllllll}-26.69 & 0.93 & 0.02 & -31.81 & 0.00 & 0.00 & -0.04\end{array}$

$\begin{array}{lllllll}-27.50 & 0.44 & 0.53 & -31.67 & 0.02 & 0.01 & -0.42\end{array}$

$\begin{array}{lllllll}-27.07 & 0.81 & -0.67 & -31.29 & 0.01 & 0.01 & -0.26\end{array}$

$\begin{array}{lllllll}-26.46 & 3.67 & 0.47 & -28.72 & 0.02 & 0.06 & -0.46\end{array}$

$\begin{array}{lllllll}-27.23 & 2.30 & 0.02 & -31.81 & 0.02 & 0.04 & -0.51\end{array}$

$\begin{array}{lllllll}-26.70 & 2.40 & 0.53 & -31.67 & 0.04 & 0.10 & -1.09\end{array}$

$\begin{array}{lllllll}-26.05 & 2.31 & -0.67 & -31.29 & 0.01 & 0.03 & -0.35\end{array}$

$\begin{array}{lllllll}-25.88 & 2.80 & 0.47 & -28.72 & 0.00 & 0.01 & -0.07\end{array}$

$\begin{array}{lllllll}-27.29 & -0.07 & 0.02 & -31.81 & 0.00 & 0.00 & -0.05\end{array}$

$\begin{array}{lllllll}-27.05 & 0.20 & -0.67 & -31.29 & 0.10 & 0.02 & -2.60\end{array}$

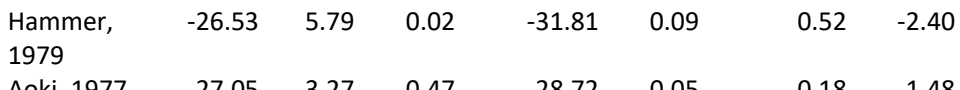

$\begin{array}{llllllll}\text { Aoki, } 1977 & -27.05 & 3.27 & 0.47 & -28.72 & 0.05 & 0.18 & -1.48\end{array}$

$\begin{array}{lllllll}-26.82 & 2.27 & 0.53 & -31.67 & 0.04 & 0.09 & -1.02\end{array}$

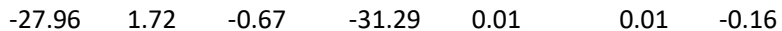

$\begin{array}{llllllll}\text { Hammer, } & -24.73 & 9.29 & 0.47 & -28.72 & 0.01 & 0.05 & -0.13\end{array}$

$\begin{array}{llllllll}1979 & -27.37 & 1.17 & 0.02 & -31.81 & 0.03 & 0.04 & -0.94\end{array}$

$\begin{array}{llllllll}\text { Hammer, } & -26.55 & 4.19 & 0.47 & -28.72 & 0.02 & 0.08 & -0.49\end{array}$

$\begin{array}{llllllll}1982 & -26.42 & -2.93 & 0.53 & -31.67 & 0.01 & -0.02 & -0.20\end{array}$

$\begin{array}{lllllll}-26.62 & 7.12 & -0.67 & -31.29 & 0.01 & 0.10 & -0.36\end{array}$

$\begin{array}{llllllll}\text { Ermilov, } & -26.92 & 2.25 & 0.47 & -28.72 & 0.03 & 0.07 & -0.86\end{array}$

Sandmann,

Klarner,

Widyastuti

\& Scheu,

2015

$\begin{array}{llllllll}-28.10 & 2.68 & -0.67 & -31.29 & 0.02 & 0.05 & -0.50\end{array}$

$\begin{array}{llllllll}\text { Jacot, } 1936 & -25.56 & 1.68 & 0.02 & -31.81 & 0.27 & 0.45 & -6.82\end{array}$

$\begin{array}{llllllll}\text { (Hammer, } & -24.06 & 1.16 & 0.47 & -28.72 & 0.01 & 0.01 & -0.21\end{array}$ 1979)

$\begin{array}{lllllll}-25.96 & 1.44 & 0.02 & -31.81 & 0.04 & 0.06 & -1.03\end{array}$

$\begin{array}{lllllll}-25.55 & -0.13 & 0.53 & -31.67 & 0.00 & 0.00 & -0.06\end{array}$

$\begin{array}{lllllll}-26.11 & 1.07 & -0.67 & -31.29 & 0.08 & 0.09 & -2.11\end{array}$

$\begin{array}{lllllll}-27.00 & 3.57 & 0.53 & -31.67 & 0.00 & 0.01 & -0.07\end{array}$

$\begin{array}{lllllll}-25.64 & 2.22 & -0.67 & -31.29 & 0.01 & 0.03 & -0.37\end{array}$

$\begin{array}{llllllll}\text { (Mahunka, } & -27.31 & 2.53 & 0.53 & -31.67 & 0.04 & 0.10 & -1.09\end{array}$

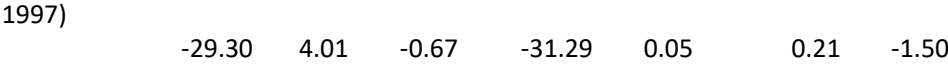

$\begin{array}{lllllllll}\text { Csiszár, } & -27.42 & 1.24 & 0.47 & -28.72 & 0.02 & 0.02 & -0.51\end{array}$

$\begin{array}{llllllll}1961 & -28.05 & 2.44 & 0.02 & -31.81 & 0.02 & 0.05 & -0.59\end{array}$

$\begin{array}{lllllll}-28.05 & 2.44 & 0.02 & -31.81 & 0.02 & 0.05 & -0.59 \\ -27.61 & 0.03 & 0.53 & -31.67 & 0.01 & 0.00 & -0.39\end{array}$

$\begin{array}{lllllll}-27.43 & 2.27 & -0.67 & -31.29 & 0.04 & 0.08 & -1.00\end{array}$

$\begin{array}{lllllllll}\text { Ermilov, } & -27.73 & 3.51 & 0.47 & -28.72 & 0.19 & 0.67 & -5.32\end{array}$

Sandmann

\& Scheu,

2019

$\begin{array}{llllllll} & -27.53 & 1.43 & 0.02 & -31.81 & 0.17 & 0.24 & -4.64 \\ & -28.40 & 1.85 & 0.53 & -31.67 & 0.04 & 0.08 & -1.22 \\ & -27.60 & 2.24 & -0.67 & -31.29 & 0.07 & 0.16 & -1.96 \\ \begin{array}{l}\text { Grandjean, } \\ 1934\end{array} & -26.56 & 1.32 & 0.47 & -28.72 & 0.08 & 0.10 & -2.10 \\ & -27.91 & 3.33 & 0.02 & -31.81 & 0.03 & 0.10 & -0.86 \\ & -26.53 & 5.21 & 0.53 & -31.67 & 0.00 & 0.01 & -0.06 \\ \text { Balogh \& } & -27.28 & 4.57 & -0.67 & -31.29 & 0.03 & 0.14 & -0.85 \\ \text { Mahunka, } & -27.01 & 1.22 & 0.53 & -31.67 & 0.02 & 0.02 & -0.49 \\ \text { 1974 } & & & & & & & \end{array}$




\begin{tabular}{|c|c|c|c|c|c|c|c|c|c|c|}
\hline BF4 & & & & -26.86 & 5.26 & -0.67 & -31.29 & 0.05 & 0.29 & -1.46 \\
\hline BF1 & 405672 & Parhypochthonius asiaticus & $\begin{array}{l}\text { Mahunka, } \\
1997\end{array}$ & -27.08 & 4.01 & 0.47 & -28.72 & 0.00 & 0.01 & -0.04 \\
\hline BF1 & 405548 & Pergalumna paraindistincta & $\begin{array}{l}\text { Ermilov, } \\
\text { Sandmann, } \\
\text { Klarner, } \\
\text { Widyastuti } \\
\text { \& Scheu, } \\
2015\end{array}$ & -27.22 & 3.05 & 0.47 & -28.72 & 0.18 & 0.54 & -4.79 \\
\hline BF2 & & & & -27.55 & 2.95 & 0.02 & -31.81 & 0.08 & 0.24 & -2.22 \\
\hline BF3 & & & & -26.99 & 1.95 & 0.53 & -31.67 & 0.00 & 0.01 & -0.11 \\
\hline BF2 & 405470 & $\begin{array}{l}\text { [B08] [2] Phyllhermannia } \\
\text { similis (405470) }\end{array}$ & & -27.01 & 0.62 & 0.02 & -31.81 & 0.01 & 0.01 & -0.24 \\
\hline BF3 & & & & -27.64 & -1.38 & 0.53 & -31.67 & 0.39 & -0.54 & -10.90 \\
\hline BF4 & & & & -27.58 & -1.20 & -0.67 & -31.29 & 0.20 & -0.23 & -5.40 \\
\hline BF1 & & & & -26.67 & 0.70 & 0.47 & -28.72 & 0.18 & 0.13 & -4.87 \\
\hline BF1 & 405671 & Protoribates paracapucinus & $\begin{array}{l}\text { (Mahunka, } \\
\text { 1988) }\end{array}$ & -26.48 & -0.54 & 0.47 & -28.72 & 0.01 & -0.01 & -0.28 \\
\hline BF2 & & & & -26.50 & 3.54 & 0.02 & -31.81 & 0.02 & 0.06 & -0.48 \\
\hline BF4 & & & & -25.96 & 5.29 & -0.67 & -31.29 & 0.01 & 0.05 & -0.26 \\
\hline BF2 & 405449 & Scheloribates praeincisus & $\begin{array}{l}\text { (Berlese, } \\
\text { 1910) }\end{array}$ & -29.33 & -0.56 & 0.02 & -31.81 & 0.01 & -0.01 & -0.34 \\
\hline BF3 & & & & -27.20 & 1.61 & 0.53 & -31.67 & 0.04 & 0.06 & -1.00 \\
\hline BF4 & & & & -26.49 & 2.83 & -0.67 & -31.29 & 0.01 & 0.03 & -0.32 \\
\hline BF2 & 405668 & Suctotegeus tumescitus & $\begin{array}{l}\text { Mahunka, } \\
1987\end{array}$ & -27.77 & 7.15 & 0.02 & -31.81 & 0.00 & 0.02 & -0.08 \\
\hline BF1 & 405457 & Tectocepheus minor & $\begin{array}{l}\text { Berlese, } \\
1903\end{array}$ & -26.59 & -0.39 & 0.47 & -28.72 & 0.01 & 0.00 & -0.19 \\
\hline BF2 & & & & -27.03 & 1.27 & 0.02 & -31.81 & 0.00 & 0.00 & -0.05 \\
\hline BF3 & & & & -26.16 & 16.63 & 0.53 & -31.67 & 0.02 & 0.37 & -0.58 \\
\hline BF4 & & & & -26.63 & 5.39 & -0.67 & -31.29 & 0.01 & 0.05 & -0.25 \\
\hline BF1 & 405389 & Trachyoribates shibai & (Aoki, 1976) & -26.76 & 5.45 & 0.47 & -28.72 & 0.01 & 0.04 & -0.19 \\
\hline BF2 & & & & -26.42 & 1.86 & 0.02 & -31.81 & 0.01 & 0.02 & -0.22 \\
\hline BF3 & & & & -25.32 & 2.13 & 0.53 & -31.67 & 0.01 & 0.03 & -0.35 \\
\hline BF4 & & & & -27.07 & 2.83 & -0.67 & -31.29 & 0.03 & 0.08 & -0.73 \\
\hline BF1 & 405642 & Zetorchestes novaguineanus & $\begin{array}{l}\text { Krisper, } \\
1987\end{array}$ & -25.45 & 0.79 & 0.47 & -28.72 & 0.03 & 0.03 & -0.87 \\
\hline BF3 & & & & -28.26 & 1.84 & 0.53 & -31.67 & 0.12 & 0.22 & -3.44 \\
\hline BF4 & & & & -28.09 & 2.02 & -0.67 & -31.29 & 0.14 & 0.28 & -3.82 \\
\hline \multicolumn{11}{|c|}{ jungle rubber } \\
\hline BJ2 & 405652 & $\begin{array}{l}\text { [B08] [13] Pergalumna sp cf. } \\
\text { Pergalumna annulata } \\
\text { (405652) }\end{array}$ & $\begin{array}{l}\text { Mahunka, } \\
\text { S., } 1973\end{array}$ & -28.01 & 1.48 & -2.73 & -29.88 & 0.01 & 0.01 & -0.18 \\
\hline BJ3 & & & & -22.96 & 0.18 & -2.17 & -31.02 & 0.01 & 0.00 & -0.20 \\
\hline BJ2 & 405873 & $\begin{array}{l}\text { [B08] [141] Neoribates sp. } 1 \\
(405873)\end{array}$ & & -26.95 & 1.42 & -2.73 & -29.88 & 0.16 & 0.23 & -4.30 \\
\hline BJ4 & 405701 & $\begin{array}{l}\text { [B08] [146] Apoplophora } \\
\text { phalerata (405701) }\end{array}$ & & -25.75 & 3.79 & -1.65 & -31.40 & 0.11 & 0.42 & -2.89 \\
\hline BJ2 & & & & -24.49 & 1.85 & -2.73 & -29.88 & 0.00 & 0.00 & -0.03 \\
\hline BJ3 & & & & -25.52 & 0.42 & -2.17 & -31.02 & 0.11 & 0.05 & -2.77 \\
\hline BJ4 & & & & -24.71 & -0.47 & -1.65 & -31.40 & 0.00 & 0.00 & -0.06 \\
\hline BJ5 & & & & -24.74 & 3.70 & -1.26 & -32.45 & 0.00 & 0.00 & -0.03 \\
\hline BJ3 & 405704 & $\begin{array}{l}\text { [B08] [164] Dampfiella sp. } 1 \\
(405704)\end{array}$ & & -26.17 & -0.39 & -2.17 & -31.02 & 0.03 & -0.01 & -0.78 \\
\hline BJ4 & & & & -25.85 & -2.47 & -1.65 & -31.40 & 0.02 & -0.05 & -0.47 \\
\hline BJ3 & 405897 & $\begin{array}{l}\text { [B08] [173] cf Prototritia sp. } \\
1 \text { (405897) }\end{array}$ & & -25.24 & 4.07 & -2.17 & -31.02 & 0.00 & 0.01 & -0.07 \\
\hline BJ4 & & & & -24.97 & 3.25 & -1.65 & -31.40 & 0.01 & 0.04 & -0.27 \\
\hline BJ5 & & & & -24.63 & 3.26 & -1.26 & -32.45 & 0.04 & 0.12 & -0.88 \\
\hline BJ2 & 405729 & $\begin{array}{l}\text { [B08] [30] Plonaphacarus } \\
\text { kugohi (405729) }\end{array}$ & Aoki, 1959 & -24.00 & -0.73 & -2.73 & -29.88 & 0.03 & -0.02 & -0.80 \\
\hline BJ2 & 405478 & $\begin{array}{l}\text { [B08] [4] Rostrozetes sp. } 7 \\
(405478)\end{array}$ & & -26.83 & 1.63 & -2.73 & -29.88 & 0.00 & 0.00 & -0.07 \\
\hline BJ3 & & & & -27.35 & 1.56 & -2.17 & -31.02 & 0.00 & 0.00 & -0.04 \\
\hline
\end{tabular}


BJ4

BJ5

BJ3 405877 [B08] [49] Phyllochthonius sp. cf. Phyllochthonius aoutii (405877)

BJ4

BJ5

BJ3

405675 [B08] [8] Dolicheremaeus

sumatranus (form 2) cf.

Dolicheremaeus sumatranus (405675)

BJ2 $405525 \quad$ [B08] [85] Megalotocepheus crinitus (405525)

BJ4

BJ3

BJ2

405885 [B08] [96] Afronothrus

incisivus (405885)

405539 Allogalumna indonesiensis

BJ3

434473 Allogalumna nov. sp. 2

BJ2

405541

Cosmogalumna areticulata

BJ5

BJ3

BJ2

BJ3

$\mathrm{BJ} 2$

BJ5

BJ4

BJ3

BJ2

BJ5

BJ2

BJ3

BJ4

BJ3

BJ2

BJ3

BJ4

BJ5

405393 Cyrthermannia tuberculata

405618 Eohypochthonius salicifolius

405620 Eremulus densus

405544 Galumna indonesica

\section{Galumnopsis reducta}

405638

Gehypochthonius

rhadamanthus

405627 Hemileius perforatoides

405573 Hoplophorella cucullata

$405875 \quad$ Kalloia gerdweigmanni

$405454 \quad$ Lamellobates misella
$405530 \quad$ Lamellobates orientalis

$\begin{array}{lllllll}-26.85 & 2.83 & -1.65 & -31.40 & 0.02 & 0.06 & -0.54 \\ -27.95 & 1.45 & -1.26 & -32.45 & 0.00 & 0.00 & -0.02 \\ -23.96 & -0.57 & -2.17 & -31.02 & 0.06 & -0.03 & -1.34 \\ & & & & & & \\ & & & & & & \\ -25.32 & 3.28 & -1.65 & -31.40 & 0.01 & 0.03 & -0.24 \\ & & & & & & \\ -30.23 & -0.21 & -1.26 & -32.45 & 0.00 & 0.00 & -0.12 \\ -25.57 & 1.09 & -2.17 & -31.02 & 0.01 & 0.01 & -0.33\end{array}$

(Berlese, $-25.01 \quad 0.89$ $-2.73$ $-29.88$

0.00

$\begin{array}{lllll}-24.66 & 2.38 & -1.65 & -31.40 & 0.19\end{array}$

$\begin{array}{lllll}-25.95 & -0.56 & -2.17 & -31.02 & 0.04\end{array}$

$\begin{array}{rrrr}-25.95 & -0.56 & -2.17 \\ -26.12 & -1.13 & -2.73\end{array}$

$-29.88 \quad 0.00$

Ermilov, Sandmann,

Klarner,

Widyastuti

\& Scheu,

2015

Ermilov,

$\begin{array}{lllll}-26.88 & 1.32 & -2.17 & -31.02 & 0.08\end{array}$

$\begin{array}{ll}0.11 & -2.27\end{array}$

$\begin{array}{lllll}-26.04 & 0.81 & -2.73 & -29.88 & 0.00\end{array}$

$0.00 \quad-0.10$

Sandmann,

Klarner,

Widyastuti

\& Scheu,

2015

Balogh,

1958

Hammer,

1979

Hammer,

1979

Ermilov

Sandmann,

Klarner,

Widyastuti

\& Scheu,

2015

\begin{tabular}{|c|c|c|c|c|c|c|c|}
\hline & -26.89 & 1.49 & -1.26 & -32.45 & 0.08 & 0.12 & -2.12 \\
\hline $\begin{array}{l}\text { (Mahunka, } \\
\text { 1995) }\end{array}$ & -25.69 & 3.96 & -1.65 & -31.40 & 0.01 & 0.06 & -0.38 \\
\hline Jacot, 1936 & -27.04 & 3.84 & -2.17 & -31.02 & 0.00 & 0.02 & -0.13 \\
\hline \multirow{2}{*}{$\begin{array}{l}\text { (Hammer, } \\
\text { 1979) }\end{array}$} & -26.27 & 0.25 & -2.73 & -29.88 & 0.02 & 0.01 & -0.62 \\
\hline & -25.94 & 2.15 & -1.26 & -32.45 & 0.43 & 0.92 & $-11.1 \mathrm{C}$ \\
\hline \multirow{2}{*}{$\begin{array}{l}\text { (Ewing, } \\
1909 \text { ) }\end{array}$} & -25.11 & 2.47 & -2.73 & -29.88 & 0.01 & 0.01 & -0.15 \\
\hline & -25.63 & 5.09 & -2.17 & -31.02 & 0.01 & 0.06 & -0.31 \\
\hline $\begin{array}{l}\text { Ermilov, } \\
\text { Sandmann } \\
\text { \& Scheu, } \\
2019\end{array}$ & -24.56 & 0.38 & -1.65 & -31.40 & 0.01 & 0.00 & -0.23 \\
\hline $\begin{array}{l}\text { (Berlese, } \\
1910)\end{array}$ & -25.70 & 3.92 & -2.17 & -31.02 & 0.01 & 0.05 & -0.33 \\
\hline \multirow{4}{*}{$\begin{array}{l}\text { Csiszár, } \\
1961\end{array}$} & -28.13 & 3.94 & -2.73 & -29.88 & 0.10 & 0.38 & -2.73 \\
\hline & -29.13 & -1.69 & -2.17 & -31.02 & 0.06 & -0.11 & -1.88 \\
\hline & -28.54 & 3.92 & -1.65 & -31.40 & 0.08 & 0.33 & -2.42 \\
\hline & -28.64 & 0.15 & -1.26 & -32.45 & 0.17 & 0.03 & -4.84 \\
\hline
\end{tabular}




\begin{tabular}{|c|c|c|c|c|c|c|c|c|c|c|}
\hline BJ2 & 405472 & Magyaria leonilae & $\begin{array}{l}\text { Ermilov, } \\
\text { Sandmann } \\
\text { \& Scheu, } \\
2019\end{array}$ & -28.18 & 0.59 & -2.73 & -29.88 & 0.13 & 0.08 & -3.61 \\
\hline BJ3 & & & & -28.67 & 1.34 & -2.17 & -31.02 & 0.13 & 0.18 & -3.86 \\
\hline BJ4 & & & & -28.83 & 1.70 & -1.65 & -31.40 & 0.04 & 0.06 & -1.08 \\
\hline BJ5 & & & & -27.89 & -1.62 & -1.26 & -32.45 & 0.22 & -0.35 & -6.08 \\
\hline BJ2 & 405470 & $\begin{array}{l}\text { [B08] [2] Phyllhermannia } \\
\text { similis (405470) }\end{array}$ & & -28.73 & -1.70 & -2.73 & -29.88 & 0.51 & -0.87 & -14.68 \\
\hline BJ3 & 405470 & & & -26.64 & -2.04 & -2.17 & -31.02 & 0.29 & -0.59 & -7.75 \\
\hline BJ4 & 405470 & & & -27.52 & -0.29 & -1.65 & -31.40 & 0.33 & -0.10 & -9.20 \\
\hline BJ2 & 405671 & Protoribates paracapucinus & $\begin{array}{l}\text { (Mahunka, } \\
\text { 1988) }\end{array}$ & -26.02 & 4.76 & -2.73 & -29.88 & 0.00 & 0.01 & -0.04 \\
\hline BJ3 & & & & -25.86 & 2.87 & -2.17 & -31.02 & 0.04 & 0.12 & -1.05 \\
\hline BJ4 & & & & -25.88 & 1.11 & -1.65 & -31.40 & 0.03 & 0.04 & -0.86 \\
\hline BJ2 & 405449 & Scheloribates praeincisus & $\begin{array}{l}\text { (Berlese, } \\
\text { 1910) }\end{array}$ & -27.30 & 0.47 & -2.73 & -29.88 & 0.01 & 0.00 & -0.22 \\
\hline BJ4 & & & & -27.31 & 2.76 & -1.65 & -31.40 & 0.11 & 0.30 & -2.96 \\
\hline BJ2 & 405524 & Tegeozetes tunicatus & $\begin{array}{l}\text { Berlese, } \\
1913\end{array}$ & -24.68 & -5.48 & -2.73 & -29.88 & 0.00 & 0.00 & -0.01 \\
\hline BJ3 & & & & -25.76 & 4.62 & -2.17 & -31.02 & 0.02 & 0.09 & -0.52 \\
\hline BJ4 & & & & -26.20 & 2.25 & -1.65 & -31.40 & 0.01 & 0.02 & -0.27 \\
\hline BJ5 & & & & -25.80 & 2.88 & -1.26 & -32.45 & 0.00 & 0.00 & -0.04 \\
\hline BJ2 & 405389 & Trachyoribates shibai & (Aoki, 1976) & -26.35 & 6.03 & -2.73 & -29.88 & 0.01 & 0.08 & -0.35 \\
\hline BJ3 & & & & -25.75 & 5.65 & -2.17 & -31.02 & 0.03 & 0.16 & -0.71 \\
\hline BJ4 & & & & -24.73 & 2.70 & -1.65 & -31.40 & 0.01 & 0.02 & -0.16 \\
\hline BJ5 & & & & -25.68 & -2.12 & -1.26 & -32.45 & 0.00 & 0.00 & -0.06 \\
\hline \multicolumn{11}{|c|}{ rubber plantation } \\
\hline BR2 & 405455 & $\begin{array}{l}\text { [B08] [111] Lamellobates } \\
\text { molecula mol (405455) }\end{array}$ & & -33.63 & 5.54 & -2.02 & -29.71 & 0.10 & 0.57 & -3.47 \\
\hline BR2 & 405639 & $\begin{array}{l}\text { [B08] [13] Pergalumna sp cf. } \\
\text { Pergalumna annulata } \\
\text { (405652) }\end{array}$ & & -29.25 & 1.35 & -2.02 & -29.71 & 0.51 & 0.69 & -15.02 \\
\hline BR1 & 405379 & $\begin{array}{l}\text { [B08] [17] Rostrozetes cf } \\
\text { shibai cf. Rostrozetes shibai } \\
\text { (405379) }\end{array}$ & & -33.82 & -1.00 & -1.92 & -29.76 & 0.06 & -0.06 & -1.87 \\
\hline BR1 & 405450 & $\begin{array}{l}\text { [B08] [20] Bischeloribates } \\
\text { mahunkai (405450) }\end{array}$ & Subías 2010 & -26.30 & 5.59 & -1.92 & -29.76 & 0.17 & 0.94 & -4.41 \\
\hline BR2 & & & & -26.31 & 4.46 & -2.02 & -29.71 & 0.10 & 0.45 & -2.64 \\
\hline BR4 & & & & -27.49 & 5.68 & -0.67 & -29.56 & 0.62 & 3.52 & -17.03 \\
\hline BR1 & 405729 & $\begin{array}{l}\text { [B08] [30] Plonaphacarus } \\
\text { kugohi (405729) }\end{array}$ & Aoki, 1959 & -21.55 & 4.37 & -1.92 & -29.76 & 0.01 & 0.04 & -0.22 \\
\hline BR2 & & & & -23.25 & 1.82 & -2.02 & -29.71 & 0.03 & 0.05 & -0.65 \\
\hline BR4 & & & & -24.25 & 2.30 & -0.67 & -29.56 & 0.14 & 0.31 & -3.30 \\
\hline BR1 & 405390 & $\begin{array}{l}\text { [B08] [74] Rostrozetes cf } \\
\text { florens cf. Trachyoribates } \\
\text { florens (405390) }\end{array}$ & $\begin{array}{l}\text { (Balogh, } \\
1970)\end{array}$ & -35.49 & -2.67 & -1.92 & -29.76 & 0.02 & -0.05 & -0.66 \\
\hline BR1 & 405381 & Archegozetes longisetosus & Aoki, 1965 & -27.63 & 4.07 & -1.92 & -29.76 & 0.58 & 2.36 & -16.03 \\
\hline BR4 & & & & -28.16 & 2.88 & -0.67 & -29.56 & 0.00 & 0.01 & -0.13 \\
\hline BR1 & 405393 & Cyrthermannia tuberculata & $\begin{array}{l}\text { Balogh, } \\
1958\end{array}$ & -29.18 & 0.80 & -1.92 & -29.76 & 0.01 & 0.01 & -0.36 \\
\hline BR3 & & & & -36.38 & -5.51 & -1.55 & -30.01 & 0.02 & -0.11 & -0.75 \\
\hline BR1 & 405620 & Eremulus densus & $\begin{array}{l}\text { Hammer, } \\
1979\end{array}$ & -34.45 & -3.62 & -1.92 & -29.76 & 0.02 & -0.08 & -0.80 \\
\hline BR1 & 405664 & Galumna sabahna & $\begin{array}{l}\text { Mahunka, } \\
1995\end{array}$ & -29.12 & 7.25 & -1.92 & -29.76 & 0.01 & 0.09 & -0.37 \\
\hline BR2 & & & & -29.39 & 2.06 & -2.02 & -29.71 & 0.06 & 0.13 & -1.85 \\
\hline BR4 & & & & -29.80 & 4.99 & -0.67 & -29.56 & 0.18 & 0.88 & -5.27 \\
\hline BR1 & 405638 & $\begin{array}{l}\text { Gehypochthonius } \\
\text { rhadamanthus }\end{array}$ & Jacot, 1936 & -35.33 & 2.45 & -1.92 & -29.76 & 0.05 & 0.12 & -1.70 \\
\hline BR2 & & & & -27.86 & 10.24 & -2.02 & -29.71 & 0.05 & 0.51 & -1.38 \\
\hline BR1 & 405386 & Otocepheus heterosetiger & Aoki, 1965 & -29.04 & 1.94 & -1.92 & -29.76 & 0.00 & 0.01 & -0.08 \\
\hline BR4 & & & & -25.51 & 2.88 & -0.67 & -29.56 & 0.04 & 0.11 & -1.01 \\
\hline
\end{tabular}




\begin{tabular}{|c|c|c|c|c|c|c|c|c|c|c|}
\hline BR1 & 405671 & Protoribates paracapucinus & $\begin{array}{l}\text { (Mahunka, } \\
\text { 1988) }\end{array}$ & -26.37 & 6.73 & -1.92 & -29.76 & 0.05 & 0.33 & -1.29 \\
\hline BR3 & & & & -25.90 & 4.06 & -1.55 & -30.01 & 0.75 & 3.06 & -19.51 \\
\hline BR4 & & & & -25.42 & -1.74 & -0.67 & -29.56 & 0.02 & -0.04 & -0.59 \\
\hline BR1 & 405449 & Scheloribates praeincisus & $\begin{array}{l}\text { (Berlese, } \\
\text { 1910) }\end{array}$ & -25.06 & 0.36 & -1.92 & -29.76 & 0.00 & 0.00 & -0.11 \\
\hline BR2 & & & & -26.60 & 4.11 & -2.02 & -29.71 & 0.09 & 0.38 & -2.44 \\
\hline BR3 & & & & -27.97 & 2.35 & -1.55 & -30.01 & 0.19 & 0.44 & -5.28 \\
\hline BR1 & 405524 & Tegeozetes tunicatus & $\begin{array}{l}\text { Berlese, } \\
1913\end{array}$ & -26.36 & 1.59 & -1.92 & -29.76 & 0.02 & 0.03 & -0.41 \\
\hline BR2 & & & & -25.53 & 4.23 & -2.02 & -29.71 & 0.03 & 0.15 & -0.89 \\
\hline BR3 & & & & -26.33 & 1.87 & -1.55 & -30.01 & 0.01 & 0.02 & -0.33 \\
\hline BR2 & 405389 & Trachyoribates shibai & (Aoki, 1976) & -28.02 & 1.41 & -2.02 & -29.71 & 0.01 & 0.02 & -0.42 \\
\hline BR3 & & & & -29.85 & -3.17 & -1.55 & -30.01 & 0.02 & -0.08 & -0.73 \\
\hline \multicolumn{11}{|c|}{ oil palm plantation } \\
\hline $\mathrm{BO} 2$ & 405718 & $\begin{array}{l}\text { [B08] [107] Rostrozetes sp. } \\
1 \text { (405718) }\end{array}$ & & -27.83 & 5.15 & 0.29 & -29.59 & 0.19 & 0.99 & -5.33 \\
\hline BO3 & & & & -27.98 & 6.20 & 0.84 & -30.24 & 0.00 & 0.01 & -0.06 \\
\hline BO4 & & & & -27.89 & 3.14 & -0.19 & -32.14 & 0.05 & 0.16 & -1.39 \\
\hline BO5 & & & & -25.78 & 4.28 & 1.27 & -29.89 & 0.02 & 0.07 & -0.42 \\
\hline BO3 & 405450 & $\begin{array}{l}\text { [B08] [20] Bischeloribates } \\
\text { mahunkai (405450) }\end{array}$ & Subías 2010 & -27.36 & 5.52 & 0.84 & -30.24 & 0.11 & 0.61 & -3.03 \\
\hline $\mathrm{BO} 2$ & 405446 & $\begin{array}{l}\text { [B08] [62] Masthermannia } \\
\text { sp. cf. Masthermannia } \\
\text { mammillaris (405446) }\end{array}$ & & -26.59 & 13.55 & 0.29 & -29.59 & 0.26 & 3.58 & -7.03 \\
\hline BO3 & & & & -31.95 & 4.33 & 0.84 & -30.24 & 0.07 & 0.32 & -2.39 \\
\hline BO5 & & & & -29.39 & 13.53 & 1.27 & -29.89 & 0.00 & 0.06 & -0.13 \\
\hline BO2 & 405506 & Allonothrus russeolus & $\begin{array}{l}\text { Wallwork, } \\
1960\end{array}$ & -27.48 & 5.42 & 0.29 & -29.59 & 0.12 & 0.64 & -3.26 \\
\hline BO3 & & & & -28.28 & 4.13 & 0.84 & -30.24 & 0.31 & 1.28 & -8.77 \\
\hline BO5 & & & & -29.48 & 4.83 & 1.27 & -29.89 & 0.76 & 3.69 & -22.52 \\
\hline $\mathrm{BO}$ & 405381 & Archegozetes longisetosus & Aoki, 1965 & -29.42 & 1.11 & 0.84 & -30.24 & 0.35 & 0.39 & -10.39 \\
\hline BO4 & & & & -31.78 & 7.51 & -0.19 & -32.14 & 0.36 & 2.70 & -11.43 \\
\hline BO5 & 405634 & Galumna flabellifera & $\begin{array}{l}\text { Hammer, } \\
1979\end{array}$ & -26.56 & 6.16 & 1.27 & -29.89 & 0.13 & 0.82 & -3.52 \\
\hline BO3 & 405449 & Scheloribates praeincisus & $\begin{array}{l}\text { (Berlese, } \\
\text { 1910) }\end{array}$ & -26.45 & 2.58 & 0.84 & -30.24 & 0.12 & 0.30 & -3.05 \\
\hline BO4 & & & & -28.60 & 2.87 & -0.19 & -32.14 & 0.34 & 0.97 & -9.68 \\
\hline BO5 & & & & -28.51 & 4.51 & 1.27 & -29.89 & 0.01 & 0.06 & -0.39 \\
\hline BO2 & 405389 & Trachyoribates shibai & (Aoki, 1976) & -28.41 & 8.85 & 0.29 & -29.59 & 0.43 & 3.77 & -12.09 \\
\hline ВO3 & & & & -27.09 & 2.92 & 0.84 & -30.24 & 0.03 & 0.10 & -0.91 \\
\hline BO4 & & & & -26.41 & 4.11 & -0.19 & -32.14 & 0.25 & 1.03 & -6.66 \\
\hline BO5 & & & & -26.03 & 4.82 & 1.27 & -29.89 & 0.07 & 0.33 & -1.80 \\
\hline \multicolumn{11}{|c|}{$\begin{array}{l}\text { Harapan } \\
\text { rainforest }\end{array}$} \\
\hline HF1 & 405473 & $\begin{array}{l}\text { [B08] [12] Meristacarus nov. } \\
\text { sp. } 1 \text { (405473) }\end{array}$ & & -26.59 & 2.11 & 0.20 & -30.81 & 0.00 & 0.01 & -0.09 \\
\hline HF2 & & & & -26.89 & 0.90 & 0.03 & -31.22 & 0.03 & 0.03 & -0.78 \\
\hline HF3 & & & & -27.75 & 1.35 & 0.29 & -31.05 & 0.01 & 0.01 & -0.15 \\
\hline HF4 & 405585 & $\begin{array}{l}\text { [B08] [120] Suctobelbella sp. } \\
\text { cf. Suctobelbella reticulata } \\
(405585)\end{array}$ & & -26.73 & 0.99 & 0.25 & -30.76 & 0.08 & 0.08 & -2.22 \\
\hline HF1 & 405652 & $\begin{array}{l}\text { [B08] [13] Pergalumna sp cf. } \\
\text { Pergalumna annulata } \\
\text { (405652) }\end{array}$ & $\begin{array}{l}\text { Mahunka, } \\
\text { S., } 1973\end{array}$ & -28.36 & 2.61 & 0.20 & -30.81 & 0.08 & 0.20 & -2.21 \\
\hline HF3 & & & & -29.29 & 1.85 & 0.29 & -31.05 & 0.23 & 0.43 & -6.76 \\
\hline HF4 & & & & -27.76 & 2.41 & 0.25 & -30.76 & 0.18 & 0.44 & -5.06 \\
\hline HF1 & 405508 & $\begin{array}{l}\text { [B08] [34] Scheloribates sp. } \\
\text { cf. Scheloribates fimbriatus } \\
\text { javensis (405508) }\end{array}$ & & -26.80 & 3.69 & 0.20 & -30.81 & 0.01 & 0.02 & -0.16 \\
\hline HF4 & & & & -25.60 & 4.00 & 0.25 & -30.76 & 0.02 & 0.10 & -0.64 \\
\hline HF1 & 405709 & $\begin{array}{l}\text { [B08] [38] Neoliodes sp. } 1 \\
(405709)\end{array}$ & & -27.40 & -3.64 & 0.20 & -30.81 & 0.01 & -0.02 & -0.16 \\
\hline
\end{tabular}


HF2

HF3

HF4

HF1

HF3

HF

HF1

$\begin{array}{lll}\text { HF4 } & 434366 & \begin{array}{l}\text { Cultroribula lata } \\ \text { HF1 }\end{array} \\ \text { Eremulus baliensis } \\ \text { HF3 } & & \\ \text { HF1 } & 405626 & \text { Galumna corpuzrarosae }\end{array}$

$\begin{array}{lrl}\text { HF1 } & 405627 & \text { Hemileius perforatoides } \\ \text { HF2 } & & \\ \text { HF3 } & & \\ \text { HF4 } & & \\ \text { HF3 } & 405641 & \text { Javacarus jocelynae } \\ \text { HF1 } & 405530 & \text { Lamellobates orientalis } \\ \text { HF2 } & & \\ \text { HF3 } & & \\ \text { HF4 } & & \\ \text { HF1 } & 405472 & \text { Magyaria leonilae }\end{array}$

HF2

HF4

HF3

HF4

HF1

HF2

HF3

HF4

HF3

HF1

HF2

HF4

HF1

HF3

HF4

HF1

HF2 (405478)

405446 [B08] [62] Masthermannia

sp. cf. Masthermannia

mammillaris (405446)

405675 [B08] [8] Dolicheremaeus

sumatranus (form 2) cf.

Dolicheremaeus sumatranus (405675)

405439 Oribatella malaya

$\begin{array}{lll}-28.36 & -3.74 & 0.03\end{array}$

$\begin{array}{lll}-28.24 & -2.71 & 0.29\end{array}$

$\begin{array}{lll}-27.50 & -4.63 & 0.25\end{array}$

$\begin{array}{lll}-27.78 & 2.42 \quad 0.20\end{array}$

$\begin{array}{lll}-26.42 & 1.59 \quad 0.29\end{array}$

$-31.22 \quad 0.04$

$-0.17 \quad-1.27$

$-31.05 \quad 0.04$

$-0.10 \quad-1.07$

$\begin{array}{llll}-30.76 & 0.01 & -0.07 & -0.39\end{array}$

$\begin{array}{llll}-30.76 & 0.01 & -0.07 & -0.39 \\ -30.81 & 0.00 & 0.01 & -0.13\end{array}$

$\begin{array}{lll}-26.65 & 2.04 & 0.25\end{array}$

$-30.76 \quad 0.06$

$0.11-1.50$

$\begin{array}{lll}-26.97 & 2.11 \quad 0.20\end{array}$

$-30.81 \quad 0.05$

$0.11-1.43$

Aoki, 1961

$\begin{array}{lll}-27.00 & 2.08 & 0.25\end{array}$

$\begin{array}{lll}-27.27 & 3.98 & 0.20\end{array}$

$-30.76$

0.02

$0.03 \quad-0.41$

Hammer,

26

1982

Ermilov,

Sandmann,

Klarner,

Widyastuti

\& Scheu,

2015

(Hammer, 1979)

$\begin{array}{lll}-26.67 & 3.95 & 0.29\end{array}$

$-30.81$

$\begin{array}{lll}-27.32 & 1.37 & 0.20\end{array}$

$-31.05 \quad 0.00$

$0.04-0.28$

Jud

1991

Csiszár, 1961

udson,
991
Csiszár,
961

$\begin{array}{lll}-26.46 & 1.34 & 0.20\end{array}$

$\begin{array}{lll}-25.34 & 0.06 & 0.03\end{array}$

$\begin{array}{lll}-26.57 & 4.13 & 0.29\end{array}$

$\begin{array}{lll}-26.13 & 2.39 & 0.25\end{array}$

$\begin{array}{lll}-26.50 & 3.25 & 0.29\end{array}$

$\begin{array}{lll}-27.16 & 4.16 \quad 0.20\end{array}$

$\begin{array}{lll}-26.84 & 0.72 & 0.03\end{array}$

$\begin{array}{lll}-24.75 & 6.22 & 0.29\end{array}$

$\begin{array}{lll}-26.14 & 3.15 & 0.25\end{array}$

Ermilov,

Sandmann

\& Scheu,

2019

Balogh \&

Mahunka,

1974

$\begin{array}{lll}-27.26 & 1.70 & 0.20\end{array}$

$-30.8$

0.01

$0.00-0.03$

$0.02 \quad-0.38$

Ermilov,

$\begin{array}{lll}-27.32 & 1.30 & 0.25\end{array}$

$\begin{array}{lll}-27.54 & -1.04 & 0.03\end{array}$

$-31.22 \quad 0.25$

$\begin{array}{ll}-30.76 \quad 0.01 \\ -31.05 & 0.11\end{array}$

-31.05 0.11

$-26.81 \quad 1.17$

$-30.81 \quad 0.02$

0.03

$-0.53$

$\begin{array}{ll}-31.22 & 0.08\end{array}$

$0.00 \quad-2.00$

$\begin{array}{llll}-31.05 & 0.27 & 1.11 & -7.12\end{array}$

$\begin{array}{llll}-30.76 & 0.01 & 0.01 & -0.15\end{array}$

-31.05 0.01

$0.04 \quad-0.34$

$-30.81 \quad 0.03$

$0.12-0.77$

$-31.22 \quad 0.21$

$0.15 \quad-5.62$

$-31.05 \quad 0.02$

$0.10-0.41$

$-30.76 \quad 0.15$

$0.46-3.82$

$0.11-1.75$

Sandmann,

Klarner,

Widyastuti

\& Scheu,

2015

$\begin{array}{lll}-27.40 & 2.56 & 0.20\end{array}$

$-30.7$

$-30.81$

0.04

$0.06-1.16$

$\begin{array}{lllllll}-27.01 & -0.18 & 0.03 & -31.22 & 0.02 & 0.00 & -0.59 \\ -25.69 & 2.35 & 0.29 & -31.05 & 0.00 & 0.00 & -0.04 \\ -27.53 & 2.43 & 0.25 & -30.76 & 0.01 & 0.03 & -0.35 \\ -28.31 & -2.39 & 0.29 & -31.05 & 0.13 & -0.31 & -3.65 \\ & & & & & & \\ -27.96 & -1.05 & 0.20 & -30.81 & 0.29 & -0.31 & -8.16 \\ -28.34 & -2.09 & 0.03 & -31.22 & 0.27 & -0.56 & -7.54 \\ -28.54 & -2.43 & 0.25 & -30.76 & 0.22 & -0.54 & -6.40 \\ -29.25 & 0.73 & 0.20 & -30.81 & 0.25 & 0.18 & -7.33 \\ -29.38 & 0.51 & 0.29 & -31.05 & 0.05 & 0.02 & -1.34 \\ -28.74 & 0.48 & 0.25 & -30.76 & 0.15 & 0.07 & -4.38 \\ -26.21 & 3.80 & 0.20 & -30.81 & 0.01 & 0.04 & -0.24 \\ -26.15 & 3.18 & 0.03 & -31.22 & 0.01 & 0.03 & -0.28\end{array}$




\begin{tabular}{|c|c|c|c|c|c|c|c|c|c|c|}
\hline HF3 & & & & -25.72 & 4.03 & 0.29 & -31.05 & 0.03 & 0.12 & -0.76 \\
\hline HF4 & & & & -26.78 & 3.04 & 0.25 & -30.76 & 0.00 & 0.01 & -0.12 \\
\hline HF1 & 405642 & Zetorchestes novaguineanus & $\begin{array}{l}\text { Krisper, } \\
1987\end{array}$ & -29.07 & 1.01 & 0.20 & -30.81 & 0.04 & 0.04 & -1.06 \\
\hline HF2 & & & & -29.11 & 0.76 & 0.03 & -31.22 & 0.09 & 0.06 & -2.50 \\
\hline HF3 & & & & -28.51 & 3.72 & 0.29 & -31.05 & 0.10 & 0.38 & -2.89 \\
\hline HF4 & & & & -28.90 & 1.34 & 0.25 & -30.76 & 0.03 & 0.04 & -0.89 \\
\hline \multicolumn{11}{|c|}{ jungle rubber } \\
\hline $\mathrm{HJ} 2$ & 405650 & $\begin{array}{l}\text { [B08] [33] Apoplophora } \\
\text { pantotrema cf. Apoplophora } \\
\text { cristata }(405650)\end{array}$ & & -27.10 & 3.86 & 0.67 & -30.80 & 0.31 & 1.20 & -8.39 \\
\hline HJ4 & & & & -26.61 & 6.06 & -0.97 & -30.26 & 0.01 & 0.04 & -0.16 \\
\hline HJ4 & 405447 & $\begin{array}{l}\text { [B08] [66] Trachyoribates } \\
\text { ampulla (405447) }\end{array}$ & & -26.96 & 1.66 & -0.97 & -30.26 & 0.20 & 0.33 & -5.38 \\
\hline HJ2 & 405856 & $\begin{array}{l}\text { [B08] [88] Dolicheremaeus } \\
\text { sp. } 2 \text { (405856) }\end{array}$ & & -26.86 & 1.24 & 0.67 & -30.80 & 0.11 & 0.14 & -2.92 \\
\hline HJ4 & 405885 & $\begin{array}{l}\text { [B08] [96] Afronothrus } \\
\text { incisivus (405885) }\end{array}$ & & -26.71 & 1.09 & -0.97 & -30.26 & 0.05 & 0.05 & -1.34 \\
\hline HJ2 & 405539 & Allogalumna indonesiensis & $\begin{array}{l}\text { Ermilov, } \\
\text { Sandmann, } \\
\text { Klarner, } \\
\text { Widyastuti } \\
\text { \& Scheu, } \\
2015\end{array}$ & -27.85 & -2.54 & 0.67 & -30.80 & 0.06 & -0.15 & -1.67 \\
\hline HJ3 & & & & -26.29 & 2.85 & -0.47 & -29.70 & 0.01 & 0.02 & -0.14 \\
\hline HJ4 & & & & -26.63 & 1.86 & -0.97 & -30.26 & 0.01 & 0.02 & -0.32 \\
\hline HJ1 & 405381 & Archegozetes longisetosus & Aoki, 1965 & -26.68 & 2.31 & 0.16 & -30.12 & 0.07 & 0.17 & -1.98 \\
\hline HJ2 & & & & -28.05 & 0.90 & 0.67 & -30.80 & 0.02 & 0.01 & -0.44 \\
\hline HJ3 & & & & -26.73 & -0.59 & -0.47 & -29.70 & 0.49 & -0.29 & -13.12 \\
\hline HJ4 & & & & -26.98 & -0.15 & -0.97 & -30.26 & 0.04 & -0.01 & -0.95 \\
\hline HJ1 & 405541 & Cosmogalumna areticulata & $\begin{array}{l}\text { Ermilov, } \\
\text { Sandmann, } \\
\text { Klarner, } \\
\text { Widyastuti } \\
\text { \& Scheu, } \\
2015\end{array}$ & -25.75 & 1.93 & 0.16 & -30.12 & 0.01 & 0.03 & -0.36 \\
\hline HJ2 & & & & -27.13 & 1.90 & 0.67 & -30.80 & 0.00 & 0.01 & -0.08 \\
\hline $\mathrm{HJ} 2$ & 434366 & Cultroribula lata & Aoki, 1961 & -26.69 & 8.70 & 0.67 & -30.80 & 0.11 & 0.98 & -3.01 \\
\hline HJ3 & & & & -27.18 & -3.19 & -0.47 & -29.70 & 0.07 & -0.22 & -1.88 \\
\hline HJ4 & & & & -26.63 & -0.45 & -0.97 & -30.26 & 0.06 & -0.03 & -1.49 \\
\hline HJ1 & 405626 & Eremulus baliensis & $\begin{array}{l}\text { Hammer, } \\
1982\end{array}$ & -26.59 & 3.09 & 0.16 & -30.12 & 0.05 & 0.14 & -1.23 \\
\hline HJ2 & & & & -26.93 & 1.29 & 0.67 & -30.80 & 0.03 & 0.04 & -0.89 \\
\hline HJ3 & & & & -26.73 & 4.43 & -0.47 & -29.70 & 0.02 & 0.10 & -0.61 \\
\hline HJ4 & & & & -27.24 & 3.59 & -0.97 & -30.26 & 0.06 & 0.21 & -1.60 \\
\hline HJ1 & 405547 & Galumna corpuzrarosae & $\begin{array}{l}\text { Ermilov, } \\
\text { Sandmann, } \\
\text { Klarner, } \\
\text { Widyastuti } \\
\text { \& Scheu, } \\
2015\end{array}$ & -27.03 & 6.23 & 0.16 & -30.12 & 0.23 & 1.43 & -6.21 \\
\hline $\mathrm{HJ} 2$ & 405875 & Kalloia gerdweigmanni & $\begin{array}{l}\text { Ermilov, } \\
\text { Sandmann } \\
\text { \& Scheu, } \\
2019\end{array}$ & -25.59 & 1.61 & 0.67 & -30.80 & 0.07 & 0.12 & -1.83 \\
\hline HJ4 & & & & -26.54 & -1.67 & -0.97 & -30.26 & 0.05 & -0.08 & -1.24 \\
\hline HJ1 & 405530 & Lamellobates orientalis & $\begin{array}{l}\text { Csiszár, } \\
1961\end{array}$ & -26.53 & 0.27 & 0.16 & -30.12 & 0.11 & 0.03 & -2.89 \\
\hline HJ3 & & & & -26.88 & 2.89 & -0.47 & -29.70 & 0.24 & 0.69 & -6.40 \\
\hline HJ4 & & & & -28.24 & 2.45 & -0.97 & -30.26 & 0.09 & 0.22 & -2.52 \\
\hline HJ1 & 405386 & Otocepheus heterosetiger & Aoki, 1965 & -24.73 & 2.41 & 0.16 & -30.12 & 0.07 & 0.17 & -1.72 \\
\hline $\mathrm{HJ} 2$ & & & & -25.10 & 1.60 & 0.67 & -30.80 & 0.01 & 0.01 & -0.20 \\
\hline
\end{tabular}




\begin{tabular}{|c|c|c|c|c|c|c|c|c|c|c|}
\hline HJ1 & 405548 & Pergalumna paraindistincta & $\begin{array}{l}\text { Ermilov, } \\
\text { Sandmann, } \\
\text { Klarner, } \\
\text { Widyastuti } \\
\text { \& Scheu, } \\
2015\end{array}$ & -25.52 & 4.89 & 0.16 & -30.12 & 0.03 & 0.17 & -0.89 \\
\hline HJ2 & & & & -27.50 & 0.61 & 0.67 & -30.80 & 0.07 & 0.04 & -1.91 \\
\hline HJ4 & & & & -26.67 & 1.65 & -0.97 & -30.26 & 0.06 & 0.10 & -1.61 \\
\hline HJ4 & 405529 & Pergalumna pterinervis & $\begin{array}{l}\text { (Canestrini, } \\
1898)\end{array}$ & -26.00 & 2.85 & -0.97 & -30.26 & 0.04 & 0.11 & -1.04 \\
\hline HJ1 & 405470 & $\begin{array}{l}\text { [B08] [2] Phyllhermannia } \\
\text { similis (405470) }\end{array}$ & & -26.39 & 0.19 & 0.16 & -30.12 & 0.02 & 0.00 & -0.45 \\
\hline HJ3 & & & & -28.93 & -2.08 & -0.47 & -29.70 & 0.01 & -0.02 & -0.34 \\
\hline $\mathrm{HJ} 4$ & & & & -27.39 & -1.27 & -0.97 & -30.26 & 0.05 & -0.06 & -1.40 \\
\hline HJ1 & 405671 & Protoribates paracapucinus & $\begin{array}{l}\text { (Mahunka, } \\
\text { 1988) }\end{array}$ & -25.76 & 2.03 & 0.16 & -30.12 & 0.02 & 0.04 & -0.44 \\
\hline HJ2 & & & & -29.29 & 7.47 & 0.67 & -30.80 & 0.09 & 0.68 & -2.65 \\
\hline HJ2 & 405449 & Scheloribates praeincisus & $\begin{array}{l}\text { (Berlese, } \\
1910)\end{array}$ & -29.32 & -1.30 & 0.67 & -30.80 & 0.04 & -0.05 & -1.23 \\
\hline HJ3 & & & & -28.86 & -0.04 & -0.47 & -29.70 & 0.12 & -0.01 & -3.42 \\
\hline HJ4 & & & & -27.61 & 1.85 & -0.97 & -30.26 & 0.22 & 0.40 & -5.94 \\
\hline HJ1 & 405524 & Tegeozetes tunicatus & $\begin{array}{l}\text { Berlese, } \\
1913\end{array}$ & -26.96 & 1.49 & 0.16 & -30.12 & 0.17 & 0.25 & -4.47 \\
\hline $\mathrm{HJ} 3$ & & & & -26.97 & 2.99 & -0.47 & -29.70 & 0.04 & 0.13 & -1.18 \\
\hline HJ4 & 405389 & Trachyoribates shibai & (Aoki, 1976) & -26.02 & 4.17 & -0.97 & -30.26 & 0.05 & 0.22 & -1.39 \\
\hline HJ1 & 405642 & Zetorchestes novaguineanus & $\begin{array}{l}\text { Krisper, } \\
1987\end{array}$ & -27.09 & 1.10 & 0.16 & -30.12 & 0.22 & 0.25 & -6.03 \\
\hline HJ2 & & & & -28.37 & 0.25 & 0.67 & -30.80 & 0.08 & 0.02 & -2.15 \\
\hline HJ4 & & & & -27.52 & 0.28 & -0.97 & -30.26 & 0.03 & 0.01 & -0.75 \\
\hline \multicolumn{11}{|c|}{ rubber plantation } \\
\hline HR1 & 405455 & $\begin{array}{l}\text { [B08] [111] Lamellobates } \\
\text { molecula mol (405455) }\end{array}$ & & -24.65 & 3.39 & -0.41 & -28.80 & 0.01 & 0.02 & -0.15 \\
\hline HR2 & & & & -26.54 & -3.24 & -1.29 & -29.30 & 0.01 & -0.02 & -0.14 \\
\hline HR3 & & & & -25.39 & 6.22 & 1.92 & -29.25 & 0.31 & 1.92 & -7.84 \\
\hline HR4 & & & & -25.90 & 7.71 & 1.07 & -28.83 & 0.04 & 0.34 & -1.15 \\
\hline HR1 & 405445 & $\begin{array}{l}\text { [B08] [152] Hoplophorella } \\
\text { sp. cf. Hoplophorella vitrina } \\
\text { (405445) }\end{array}$ & & -27.57 & 3.46 & -0.41 & -28.80 & 0.01 & 0.05 & -0.38 \\
\hline HR2 & 405450 & $\begin{array}{l}\text { [B08] [20] Bischeloribates } \\
\text { mahunkai (405450) }\end{array}$ & Subías 2010 & -26.37 & 6.40 & -1.29 & -29.30 & 0.38 & 2.42 & -9.97 \\
\hline HR3 & & & & -28.03 & 8.45 & 1.92 & -29.25 & 0.16 & 1.39 & -4.61 \\
\hline HR4 & & & & -26.71 & 7.03 & 1.07 & -28.83 & 0.08 & 0.58 & -2.20 \\
\hline HR1 & 405729 & $\begin{array}{l}\text { [B08] [30] Plonaphacarus } \\
\text { kugohi (405729) }\end{array}$ & Aoki, 1959 & -27.90 & 5.68 & -0.41 & -28.80 & 0.07 & 0.39 & -1.93 \\
\hline HR3 & & & & -24.78 & 2.20 & 1.92 & -29.25 & 0.03 & 0.06 & -0.71 \\
\hline HR4 & & & & -23.05 & 2.27 & 1.07 & -28.83 & 0.29 & 0.66 & -6.67 \\
\hline HR1 & 405650 & $\begin{array}{l}\text { [B08] [33] Apoplophora } \\
\text { pantotrema cf. Apoplophora } \\
\text { cristata }(405650)\end{array}$ & & -30.79 & -1.42 & -0.41 & -28.80 & 0.17 & -0.24 & -5.29 \\
\hline HR1 & 405540 & $\begin{array}{l}\text { Allogalumna } \\
\text { paranovazealandica }\end{array}$ & $\begin{array}{l}\text { Ermilov, } \\
\text { Sandmann, } \\
\text { Klarner, } \\
\text { Widyastuti } \\
\text { \& Scheu, } \\
2015\end{array}$ & -26.39 & 1.31 & -0.41 & -28.80 & 0.00 & 0.00 & -0.04 \\
\hline HR2 & & & & -27.44 & 2.00 & -1.29 & -29.30 & 0.31 & 0.62 & -8.54 \\
\hline HR1 & 405506 & Allonothrus russeolus & $\begin{array}{l}\text { Wallwork, } \\
1960\end{array}$ & -28.74 & 1.14 & -0.41 & -28.80 & 0.22 & 0.25 & -6.34 \\
\hline HR4 & & & & -32.54 & 1.01 & 1.07 & -28.83 & 0.06 & 0.06 & -2.06 \\
\hline HR2 & 405381 & Archegozetes longisetosus & Aoki, 1965 & -27.33 & 0.98 & -1.29 & -29.30 & 0.06 & 0.06 & -1.68 \\
\hline HR3 & & & & -23.73 & 6.79 & 1.92 & -29.25 & 0.09 & 0.62 & -2.17 \\
\hline HR4 & & & & -24.86 & 9.19 & 1.07 & -28.83 & 0.05 & 0.46 & -1.25 \\
\hline HR1 & 405619 & Epilohmannoides wallworki & $\begin{array}{l}\text { Hammer, } \\
1979\end{array}$ & -27.89 & 0.75 & -0.41 & -28.80 & 0.09 & 0.06 & -2.39 \\
\hline
\end{tabular}




\begin{tabular}{|c|c|c|c|c|c|c|c|c|c|c|}
\hline HR1 & 405620 & Eremulus densus & $\begin{array}{l}\text { Hammer, } \\
1979\end{array}$ & -31.13 & -2.65 & -0.41 & -28.80 & 0.02 & -0.06 & -0.73 \\
\hline HR2 & & & & -31.18 & -6.90 & -1.29 & -29.30 & 0.05 & -0.35 & -1.58 \\
\hline HR1 & 405664 & Galumna sabahna & $\begin{array}{l}\text { Mahunka, } \\
1995\end{array}$ & -29.19 & 3.44 & -0.41 & -28.80 & 0.07 & 0.24 & -2.05 \\
\hline HR2 & & & & -26.19 & 4.38 & -1.29 & -29.30 & 0.10 & 0.45 & -2.67 \\
\hline HR2 & 405548 & Pergalumna paraindistincta & $\begin{array}{l}\text { Ermilov, } \\
\text { Sandmann, } \\
\text { Klarner, } \\
\text { Widyastuti } \\
\text { \& Scheu, } \\
2015\end{array}$ & -27.35 & 4.68 & -1.29 & -29.30 & 0.09 & 0.42 & -2.46 \\
\hline HR1 & 405671 & Protoribates paracapucinus & $\begin{array}{l}\text { (Mahunka, } \\
\text { 1988) }\end{array}$ & -25.62 & 5.95 & -0.41 & -28.80 & 0.03 & 0.17 & -0.71 \\
\hline HR3 & & & & -24.79 & 3.83 & 1.92 & -29.25 & 0.05 & 0.18 & -1.18 \\
\hline HR4 & & & & -26.08 & 6.40 & 1.07 & -28.83 & 0.18 & 1.15 & -4.67 \\
\hline HR1 & 405449 & Scheloribates praeincisus & $\begin{array}{l}\text { (Berlese, } \\
\text { 1910) }\end{array}$ & -26.17 & 3.95 & -0.41 & -28.80 & 0.19 & 0.75 & -4.94 \\
\hline HR4 & & & & -27.04 & 0.46 & 1.07 & -28.83 & 0.02 & 0.01 & -0.53 \\
\hline HR1 & 405524 & Tegeozetes tunicatus & $\begin{array}{l}\text { Berlese, } \\
1913\end{array}$ & -27.49 & 1.82 & -0.41 & -28.80 & 0.11 & 0.20 & -3.08 \\
\hline HR3 & & & & -27.72 & -2.52 & 1.92 & -29.25 & 0.36 & -0.90 & -9.95 \\
\hline HR4 & & & & -29.15 & 11.99 & 1.07 & -28.83 & 0.08 & 0.98 & -2.39 \\
\hline HR1 & 405389 & Trachyoribates shibai & (Aoki, 1976) & -27.16 & 2.54 & -0.41 & -28.80 & 0.01 & 0.02 & -0.25 \\
\hline HR2 & & & & -24.78 & 2.69 & -1.29 & -29.30 & 0.00 & 0.00 & -0.03 \\
\hline HR4 & & & & -25.15 & 3.00 & 1.07 & -28.83 & 0.19 & 0.57 & -4.77 \\
\hline \multicolumn{11}{|c|}{ oil palm plantation } \\
\hline HO1 & 405718 & $\begin{array}{l}\text { [B08] [107] Rostrozetes sp. } \\
1 \text { (405718) }\end{array}$ & & -26.91 & 4.28 & 1.63 & -29.59 & 0.22 & 0.94 & -5.92 \\
\hline HO3 & & & & -25.87 & 4.25 & 1.00 & -28.84 & 0.09 & 0.38 & -2.34 \\
\hline HO4 & & & & -27.35 & 4.89 & -0.22 & -30.27 & 0.03 & 0.15 & -0.86 \\
\hline HO1 & 405450 & $\begin{array}{l}\text { [B08] [20] Bischeloribates } \\
\text { mahunkai (405450) }\end{array}$ & Subías 2010 & -25.98 & 3.44 & 1.63 & -29.59 & 0.01 & 0.05 & -0.34 \\
\hline HO3 & & & & -26.86 & 8.32 & 1.00 & -28.84 & 0.41 & 3.40 & -11.00 \\
\hline HO2 & 405506 & Allonothrus russeolus & $\begin{array}{l}\text { Wallwork, } \\
1960\end{array}$ & -28.17 & 0.12 & 0.53 & -28.96 & 0.40 & 0.05 & -11.14 \\
\hline HO4 & & & & -28.05 & 7.55 & -0.22 & -30.27 & 0.04 & 0.29 & -1.07 \\
\hline HO1 & 405381 & Archegozetes longisetosus & Aoki, 1965 & -28.28 & 4.52 & 1.63 & -29.59 & 0.43 & 1.95 & -12.21 \\
\hline $\mathrm{HO}$ & & & & -27.46 & 4.48 & 1.00 & -28.84 & 0.39 & 1.73 & -10.59 \\
\hline HO4 & & & & -28.70 & 1.94 & -0.22 & -30.27 & 0.92 & 1.79 & -26.48 \\
\hline HO1 & 405449 & Scheloribates praeincisus & $\begin{array}{l}\text { (Berlese, } \\
\text { 1910) }\end{array}$ & -26.33 & 4.09 & 1.63 & -29.59 & 0.04 & 0.16 & -1.03 \\
\hline $\mathrm{HO} 2$ & & & & -25.67 & 4.34 & 0.53 & -28.96 & 0.03 & 0.11 & -0.64 \\
\hline HO3 & & & & -26.51 & 5.06 & 1.00 & -28.84 & 0.07 & 0.33 & -1.75 \\
\hline HO4 & & & & -26.92 & 1.04 & -0.22 & -30.27 & 0.01 & 0.01 & -0.21 \\
\hline HO1 & 405389 & Trachyoribates shibai & (Aoki, 1976) & -26.02 & 4.89 & 1.63 & -29.59 & 0.30 & 1.45 & -7.70 \\
\hline $\mathrm{HO} 2$ & & & & -26.42 & 2.51 & 0.53 & -28.96 & 0.58 & 1.45 & -15.31 \\
\hline HO3 & & & & -27.00 & 1.72 & 1.00 & -28.84 & 0.05 & 0.08 & -1.30 \\
\hline
\end{tabular}


Table S2: Single-dimensional metrics of oribatid mite community - average position ('IPos'), maximum, minimum and range (max-min). Variable $\left(\Delta^{13} \mathrm{C}\right.$ and $\left.\Delta^{15} \mathrm{~N}\right)$, land-use system, value and the letter $(\mathrm{a} / \mathrm{b} / \mathrm{ab})$ representing the significances. $\Delta^{13} \mathrm{C}$ and $\Delta^{15} \mathrm{~N}$ values were scaled between 0 and 1 based on maximum and minimum across communities to ensure equal contribution. Maximum as well as minimum of $\Delta^{13} \mathrm{C}$ and $\Delta^{15} \mathrm{~N}$ values were represented by one species with the most extreme values within the whole community. For calculation see Materials and Methods, for statistical analysis see text.

\begin{tabular}{|c|c|c|c|c|}
\hline & variable & $\begin{array}{l}\text { land-use } \\
\text { system }\end{array}$ & value & letter \\
\hline average position & $\Delta^{13} \mathrm{~N}$ & jungle rubber & 0.69 & $a$ \\
\hline average position & $\Delta^{13} \mathrm{~N}$ & rainforest & 0.67 & $a$ \\
\hline average position & $\Delta^{13} \mathrm{~N}$ & $\begin{array}{l}\text { rubber } \\
\text { plantation }\end{array}$ & 0.58 & $b$ \\
\hline average position & $\Delta^{13} N$ & $\begin{array}{l}\text { oil palm } \\
\text { plantation }\end{array}$ & 0.57 & $b$ \\
\hline average position & $\Delta^{15} \mathrm{~N}$ & $\begin{array}{l}\text { rubber } \\
\text { plantation }\end{array}$ & 0.45 & a \\
\hline average position & $\Delta^{15} \mathrm{~N}$ & $\begin{array}{l}\text { oil palm } \\
\text { plantation }\end{array}$ & 0.44 & $a$ \\
\hline average position & $\Delta^{15} \mathrm{~N}$ & jungle rubber & 0.37 & $a b$ \\
\hline average position & $\Delta{ }^{15} \mathrm{~N}$ & rainforest & 0.31 & $b$ \\
\hline maximum & $\Delta^{13} N$ & jungle rubber & 0.84 & $a$ \\
\hline maximum & $\Delta^{13} N$ & rainforest & 0.83 & a \\
\hline maximum & $\Delta^{13} N$ & $\begin{array}{l}\text { rubber } \\
\text { plantation }\end{array}$ & 0.81 & a \\
\hline maximum & $\Delta^{13} N$ & $\begin{array}{l}\text { oil palm } \\
\text { plantation }\end{array}$ & 0.69 & $b$ \\
\hline maximum & $\Delta{ }^{15} \mathrm{~N}$ & $\begin{array}{l}\text { rubber } \\
\text { plantation }\end{array}$ & 0.63 & a \\
\hline maximum & $\Delta^{15} \mathrm{~N}$ & rainforest & 0.62 & a \\
\hline maximum & $\Delta^{15} \mathrm{~N}$ & $\begin{array}{l}\text { oil palm } \\
\text { plantation }\end{array}$ & 0.61 & a \\
\hline maximum & $\Delta^{15} \mathrm{~N}$ & jungle rubber & 0.56 & a \\
\hline minimum & $\Delta^{13} \mathrm{~N}$ & rainforest & 0.57 & $a$ \\
\hline minimum & $\Delta^{13} \mathrm{~N}$ & jungle rubber & 0.57 & a \\
\hline minimum & $\Delta^{13} N$ & $\begin{array}{l}\text { oil palm } \\
\text { plantation }\end{array}$ & 0.48 & a \\
\hline minimum & $\Delta^{13} N$ & $\begin{array}{l}\text { rubber } \\
\text { plantation }\end{array}$ & 0.24 & $b$ \\
\hline minimum & $\Delta{ }^{15} \mathrm{~N}$ & $\begin{array}{l}\text { oil palm } \\
\text { plantation }\end{array}$ & 0.34 & a \\
\hline minimum & $\Delta^{15} \mathrm{~N}$ & jungle rubber & 0.20 & $\mathrm{~b}$ \\
\hline minimum & $\Delta^{15} \mathrm{~N}$ & $\begin{array}{l}\text { rubber } \\
\text { plantation }\end{array}$ & 0.16 & $b$ \\
\hline minimum & $\Delta{ }^{15} \mathrm{~N}$ & rainforest & 0.14 & $b$ \\
\hline range (max-min) & $\Delta^{13} N$ & $\begin{array}{l}\text { rubber } \\
\text { plantation }\end{array}$ & 0.57 & $a$ \\
\hline range (max-min) & $\Delta^{13} \mathrm{~N}$ & jungle rubber & 0.28 & $b$ \\
\hline range (max-min) & $\Delta^{13} N$ & rainforest & 0.25 & $b$ \\
\hline
\end{tabular}




\begin{tabular}{|c|c|c|c|c|}
\hline range (max-min) & $\Delta^{13} \mathrm{~N}$ & $\begin{array}{l}\text { oil palm } \\
\text { plantation }\end{array}$ & 0.21 & $b$ \\
\hline range (max-min) & $\Delta^{15} \mathrm{~N}$ & rainforest & 0.48 & $a$ \\
\hline range (max-min) & $\Delta{ }^{15} \mathrm{~N}$ & $\begin{array}{l}\text { rubber } \\
\text { plantation }\end{array}$ & 0.47 & a \\
\hline range (max-min) & $\Delta^{15} \mathrm{~N}$ & jungle rubber & 0.37 & $a b$ \\
\hline range (max-min) & $\Delta^{15} \mathrm{~N}$ & $\begin{array}{l}\text { oil palm } \\
\text { plantation }\end{array}$ & 0.27 & $b$ \\
\hline
\end{tabular}

Table S3: Multi-dimensional metrics of oribatid mite community - isotopic dispersion ('IDis'), isotopic divergence ('IDiv'), isotopic evenness ('IEve'), isotopic richness ('IRic'), isotopic uniqueness ('IUni'). Land-use system, value and the letter $(\mathrm{a} / \mathrm{b} / \mathrm{ab})$ representing the significances. $\Delta^{13} \mathrm{C}$ and $\Delta{ }^{15} \mathrm{~N}$ values were scaled between 0 and 1 based on maximum and minimum across communities to ensure equal contribution. Maximum as well as minimum of $\Delta{ }^{13} \mathrm{C}$ and $\Delta^{15} \mathrm{~N}$ values were represented by one species with the most extreme values within the whole community. For calculation see Materials and Methods, for statistical analysis see text.

\begin{tabular}{|c|c|c|c|}
\hline $\begin{array}{l}\text { multidimensional } \\
\text { metrics }\end{array}$ & land-use system & value & letter \\
\hline 'IDis' & oil palm plantation & 0.47 & $\mathrm{a}$ \\
\hline 'IDis' & jungle rubber & 0.47 & a \\
\hline 'IDis' & rubber plantation & 0.37 & a \\
\hline 'IDis' & rainforest & 0.32 & a \\
\hline 'IDiv' & rainforest & 0.73 & $a$ \\
\hline ‘IDiv’ & jungle rubber & 0.71 & a \\
\hline ‘IDiv’ & rubber plantation & 0.71 & a \\
\hline ‘IDiv' & oil palm plantation & 0.67 & a \\
\hline 'IEve' & oil palm plantation & 0.65 & $a$ \\
\hline 'IEve' & jungle rubber & 0.53 & a \\
\hline 'IEve' & rainforest & 0.49 & a \\
\hline 'IEve' & rubber plantation & 0.47 & a \\
\hline 'IRic' & rubber plantation & 0.13 & $a$ \\
\hline 'IRic' & jungle rubber & 0.07 & $b$ \\
\hline 'IRic' & rainforest & 0.06 & $b$ \\
\hline 'IRic' & oil palm plantation & 0.02 & $b$ \\
\hline 'IUni’ & oil palm plantation & 0.61 & $\mathrm{a}$ \\
\hline ‘IUni’ & jungle rubber & 0.46 & $a b$ \\
\hline 'IUni' & rubber plantation & 0.43 & $a b$ \\
\hline ‘IUni’ & rainforest & 0.31 & $b$ \\
\hline
\end{tabular}


Chapter IV

\section{Response of soil animal communities to tree diversity enrichment of oil palm plantations}
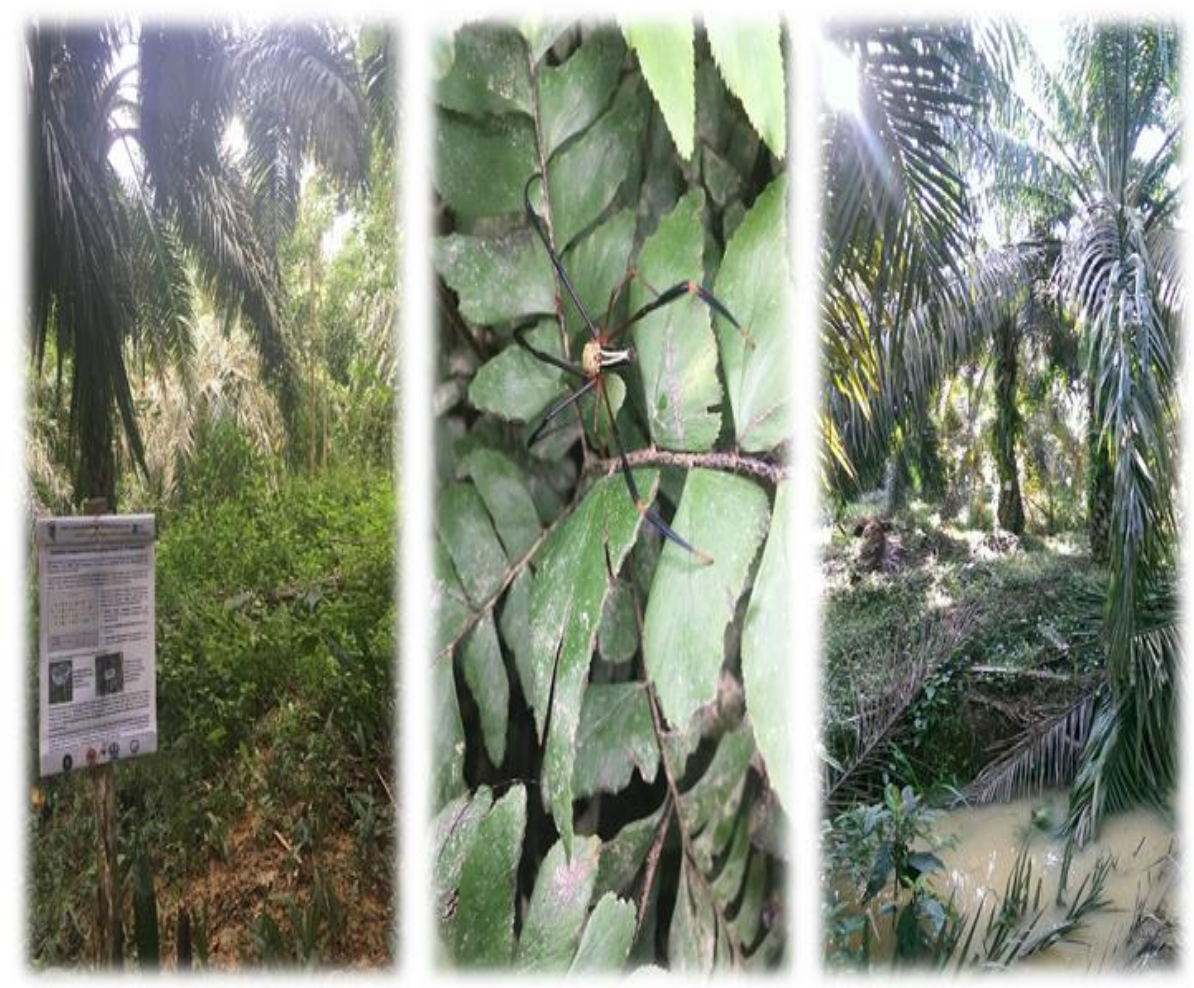

Alena Krause, Anton Potapov, Stefan Scheu and Mark Maraun 



\section{Abstract}

The transformation and degradation of landscapes is rapidly increasing worldwide. Due to the increase in the human population and increased resource demand, pressure on ecosystems is increasing strongly. Especially tropical regions are suffering. In south East Asia rainforest is increasingly transformed into cash crop monoculture plantations such as rubber, oil palm and acacia. In particular oil palm is one of the fasted expanding crops, and therefore, effects of oil palm plantation management on biodiversity and ecosystem functioning are of increasing interest. However, in particular studies on the belowground system are rare. The structure and functioning of soil systems are essential for the functioning of ecosystems. This study formed part of the 'Biodiversity Enrichment Experiment" within the interdisciplinary project "Ecological and socioeconomic functions of tropical lowland rainforest transformation systems" (EFForTS), located in southwest Sumatra, Indonesia. In this experiment 'tree islands' of varying species diversity $(0,1,2,3$ and 6 tree species) and plot sizes $(5 \times 5,10 \times 10,20 \times 20$ and $40 \times 40 \mathrm{~m})$ were established in oil palm plantations. We investigated the effect of these 'tree islands' on the soil macroand mesofauna three years after the experiment started. Neither the different diversity levels of trees nor plot size significantly affected the abundance of soil invertebrate taxa. However, the richness of soil invertebrate taxa was increased in plantations with two tree species. Overall, the results indicate that diversity and abundance of plant communities little affects the structure and diversity of soil invertebrates in the short term. However, soil animal communities are likely to respond to the enrichment of plantations by trees at later stages and this needs further investigation. 


\section{Introduction}

Transformation as well as degradation of landscapes is rapidly increasing worldwide. This is driven predominantly by the growing human population and increased use of resources; by 2050 the worldwide population size will increase to 9.7 billion people (UN, 2015). This in turn will lead to an increase in the demand of food, fuel and fiber (Dirzo and Raven, 2003; Foley et al., 2005; Gibbs et al., 2010; Newbold et al., 2015). Such demands, however, lead to high pressure on ecosystems worldwide regarding the production and yield of agricultural landscapes (Godfray et al., 2010; Lambin and Meyfroidt, 2011; Tscharntke et al., 2012). Until today $40 \%$ of the terrestrial surface is managed for agricultural purposes or transformed into agricultural systems; (Bridges and Oldeman, 1999; Reynolds et al., 2007; Foley et al., 2011; Pavao-Zuckerman and Sookhdeo, 2017; Francini et al., 2018).

Especially tropical regions suffer from degradation and transformation into different landuse systems, e.g. oil palm or rubber plantations (Sodhi et al., 2010; Wilcove et al., 2013; Meijide et al., 2018). Those transformations are threatening ecosystems with the highest rates of biodiversity and endemism worldwide (Jones, 2013). One of the rapidly increasing agricultural land-use system are vegetable oils (Clay, 2013), in particular oil palm. This is not only one of the fastest expanding crops but also one of the most versatile oils (Carter et al., 2007; Fitzherbert et al., 2008; Zimmer, 2010; Ashraf et al., 2018). In consequence of its versatility, palm oil is widely used, beyond that it is the oil seed crop that produces the highest yield of oil per land area (Zimmer, 2010; Ashraf et al., 2018). In Indonesia, transformation of rainforest into agricultural systems strongly increased in the last decades. Oil palm plantations were often established on rainforest sites which were previously logged or degraded by fire (Curran et al., 2004; Dennis et al., 2005; Fitzherbert 
et al., 2008; Drescher et al., 2016). In 2012, 0.84 million hectares of rainforest were converted into agricultural systems in Indonesia; the highest rate worldwide (Margono et al., 2014; Drescher et al., 2016).

Conversion of rainforest into plantations and intensification of land use are known to affect diversity and biomass, and therefore ecosystem functioning of above- and belowground animals and plants (Sodhi et al., 2004; Fitzherbert et al., 2008; Wilcove et al., 2013; Barnes et al., 2014; Edwards et al., 2014; Klarner et al., 2017). In particular, the reduction of decomposer diversity may reduce decomposition rates as well as carbon and nutrient cycling (Handa et al., 2014). Decomposition is one of the most important processes for terrestrial ecosystems, since about $90 \%$ of the primary production of plants enters the soil system as leaf and wood detritus or rhizodeposits (McNaughton et al., 1989; Bardgett, 2005). Soil structure and thereby the functioning of soil systems, e.g. the turnover of organic matter and nutrient cycling, can be modified by the presence of soil animal species (Bardgett, 2005; Nielsen et al., 2015). Soil animals contribute to soil functioning and energy fluxes (Brussaard et al., 2007). Even within small spatial scales the abundance and diversity of soil arthropods varies, since organisms are not distributed uniformly due to environmental gradients (Legendre and Fortin, 1989; Ettema and Wardle, 2002). Additionally, active dispersal and movement of soil organisms is limited, depending on the species from few millimeters to centimeters per day (Ettema and Wardle, 2002). Variations in abiotic as well as biotic factors, e.g. climate and litter type, are major determinants of the high spatial variability of the structure of soil communities (Coûteaux et al., 1995; Wardle et al., 2006; Berg and McClaugherty, 2008). Spatial variability of soil animals also is related to the variability in the composition and diversity 
of plant communities (Scherber et al., 2010; Eisenhauer et al., 2011; Thakur and Eisenhauer, 2015). This might be due to variations in plant species richness but also to the identity of individual plant species (Spehn et al., 2000; Wardle et al., 2006; Viketoft et al., 2009; Eisenhauer et al., 2010, 2011). The decline in plant diversity and thereby the loss of litter and root resources negatively impacts the density, diversity and functioning of soil organisms (Hooper et al., 2000; Scherber et al., 2010; Eisenhauer et al., 2011). However, studies investigating the response of soil biota to changes in plant diversity and identity for longer periods of time (Eisenhauer et al., 2009, 2011; Viketoft et al., 2009) and considering a wide range of taxonomic and functional groups are scare (Hedlund et al., 2003; Scherer-Lorenzen and Leadley, 2003; Milcu et al., 2008; Viketoft et al., 2009; Eisenhauer et al., 2011).

An option for restoring the diversity and functioning of decomposer communities is the planting of native trees (Chazdon, 2008; Teuscher et al., 2016). Planted tree islands form, among others, local areas of recovery which then might enhance or initiate natural succession not only within the tree islands but also for the surrounding environment (Yarranton and Morrison, 1974; Corbin and Holl, 2012; Teuscher et al., 2016). Increased diversity in tree islands may be due to the fact that larger area is associated with increased species richness (MacArthur and Wilson, 1963, 1967; Jonsson et al., 2009). However, the most effective island size (economically and ecologically) is still debated (Mendenhall et al., 2014; Teuscher et al., 2016). Generally, management strategies of intensively managed oil palm plantations targeting at increasing biodiversity but maintaining productivity are virtually lacking until today (Teuscher et al., 2016). 
To protect biodiversity of tropical regions it is important to integrate the belowground system and to consider the management of plantation systems (Koh et al., 2009; Foster et al., 2011; Luskin and Potts, 2011; Teuscher et al., 2015, 2016). The effects of oil palm plantation management on aboveground biodiversity and ecosystem functioning is receiving increased interest (Nurdiansyah et al., 2016; Syafiq et al., 2016; Teuscher et al., 2016; Ashton-Butt et al., 2018), however, so far studies on belowground systems are scarce (Bessou et al., 2017; Krause et al., 2019; Potapov et al., 2019; Susanti et al., 2019). The current study formed part of the interdisciplinary project "Ecological and socioeconomic functions of tropical lowland rainforest transformation systems" (EFForTS), established in Jambi Province, southwest Sumatra, Indonesia (Drescher et al., 2016). The aim of the 'Biodiversity Enrichment Experiment' was to enhance biodiversity and ecosystem functioning in oil palm plantations by 'tree islands' of varying diversity level of planted tree species and plot size. We hypothesized that the abundance, diversity and community of belowground soil invertebrate taxa will increase with both increasing plot size and increasing diversity of planted tree species.

\section{Material and Methods}

\section{Study sites}

The 'Biodiversity Enrichment Experiment', was established in 2013 in the oil palm plantation of PT Humusindo Makmur Sejata $\left(01.95^{\circ} \mathrm{S}\right.$ and $103.25^{\circ} \mathrm{E}, 47 \pm 11 \mathrm{~m}$ a.s.I.; see also paragraph "study design" of the general introduction; Fig. 2) (Teuscher et al., 2016). Loamy Acrisol is the dominant soil type (Allen et al., 2015). Within the existing oil palm plantation, 'tree islands' of varying diversity level $(0,1,2,3$ and 6 planted tree species) 
and plot size $(5 \times 5,10 \times 10,20 \times 20,40 \times 40 \mathrm{~m}$ ) were established (see Fig. 3 of the paragraph "study design" of the General Introduction). Following the random partitions design of Bell et al. (2009), 52 'tree island' were established. Additionally, four control plots ("ctrl", $10 \times 10 \mathrm{~m}$ ) without any experimental treatment, i.e. with management-asusual, were established resulting in 56 'tree islands' in total. Species composition within the 'tree island' was random and each tree species was selected only once at each species diversity level (Teuscher et al., 2016). Prior to the tree planting, $40 \%$ of the oil palms within the 'tree islands' were cut. For the enrichment of the 'tree islands' six native trees were selected including three fruit trees (Parkia speciosa, and Archidendron pauciflorum, Fabaceae; Durio zibethinus, Malvaceae), two timber trees (Peronema canescens, Lamiaceae; Shorea leprosula, Dipterocarpaceae), and one tree used for the production of latex (Dyera polyphylla, Apocynaceae). Management of the 'tree island' plots contained manual weeding in the first two years (preventing weeds to overgrow planted saplings; done every three months). Manual weeding was stopped thereafter to allow natural succession as well as interaction/competition of native trees with each other and oil palms. Application of fertilizer, herbicides and pesticides in 'tree island' plots was stopped after tree planting. More details on the study sites and experimental design are given in Teuscher et al. (2016). Samples for soil invertebrate extraction were taken in 2016 after manual weeding was finished.

\section{Sampling, extraction and species determination}

In October to November 2016, four soil samples $(16 \times 16 \mathrm{~cm}$, litter layer and $0-5 \mathrm{~cm}$ of mineral soil) were taken randomly from a $5 \times 5$ m subplot established in each plot, i.e. a 
total of 224 samples were taken. In the $5 \times 5 \mathrm{~m}$ plot the full plot area was used for taking samples. The samples were transported to the laboratory and extracted by heat (Kempson et al., 1963). Soil invertebrates were transferred into ethanol (70 \%) and sorted to high rank taxa including Oribatida, Collembola, Annelida and Chilopoda (Table S1). The taxa were assigned to size classes of meso- and macrofauna (Table S1 and S2).

\section{Statistical analysis}

The numbers of individuals of the four samples per subplot were summed up and given as number of individuals per square meter. Further, the number of meso- and macrofauna taxa of the four samples per subplot were summed up to obtain the total number of mesoand macrofauna taxa of the area sampled, i.e. $1024 \mathrm{~cm}^{2}$. Meso- and macrofauna were analyzed separately due to large differences in density. Statistical analyses were performed using R v 3.5.2 (R Core Team, 2018) with R studio interface (RStudio, Inc.). Normality and homogeneity of variance were inspected using diagnostic plots and this indicated that preconditions for parametric data analysis were met. Effects of diversity level of planted tree species and plot size were assessed using linear models (Wilkinson and Rogers, 1973; Chambers and Hastie, 1992). Significance was evaluated using the anova function (Chambers and Hastie, 1992). Data were visualized using ggplot in the ggplot2 package (Wickham, 2016).

Additionally, principal components analysis (PCA) was used to analyze and present graphically the response of the different taxa to tree diversity levels. Here, the response variables (different taxa) were log-transformed to improve homogeneity of variances. The different tree diversity levels $(0,1,2,3,6$ planted tree species) were included as 
passive/supplementary variables not affecting the ordination. PCA was performed using CANOCO 5 (Microcomputer Power, Ithaca, USA, 2012).

\section{Results}

The abundance of mesofauna was higher than the abundance of macrofauna with an overall averages of 3645 ind. $/ \mathrm{m}^{2}$ and $828 \mathrm{ind} . / \mathrm{m}^{2}$, respectively. Additionally, the richness of mesofauna was higher than the richness of macrofauna with overall averages of $160 \pm$ 26 ind./ $/ \mathrm{m}^{2}$ and $153 \pm 45 \mathrm{ind} . / \mathrm{m}^{2}$, respectively. Among macrofauna groups, Diplopoda and Coleoptera (larve) had the highest abundance with averages of 223 and $166 \mathrm{ind} . / \mathrm{m}^{2}$, respectively. Among mesofauna taxa, Collembola and Oribatida had the highest abundance with averages of 1706 and 1339 ind./ $/ \mathrm{m}^{2}$, respectively. For more detailed information see Table S1.

\section{Abundance of total macro- and mesofauna}

Tree diversity neither significantly affected the abundance of macro- nor mesofauna $\left(F_{1,50}\right.$ $=1.53, p=0.2219$ and $F_{1,50}=0.68, p=0.4122$, respectively). Although not significant, macrofauna abundance was similar at diversity level 0, 1 and 2 and lower at diversity level 3 and 6 (Figure 1a; for detailed information see Table S3). Abundance of mesofauna was highest at diversity level 2, 3 and 6 and lowest at diversity level 0 (Figure 1b; for detailed information see Table S3). 

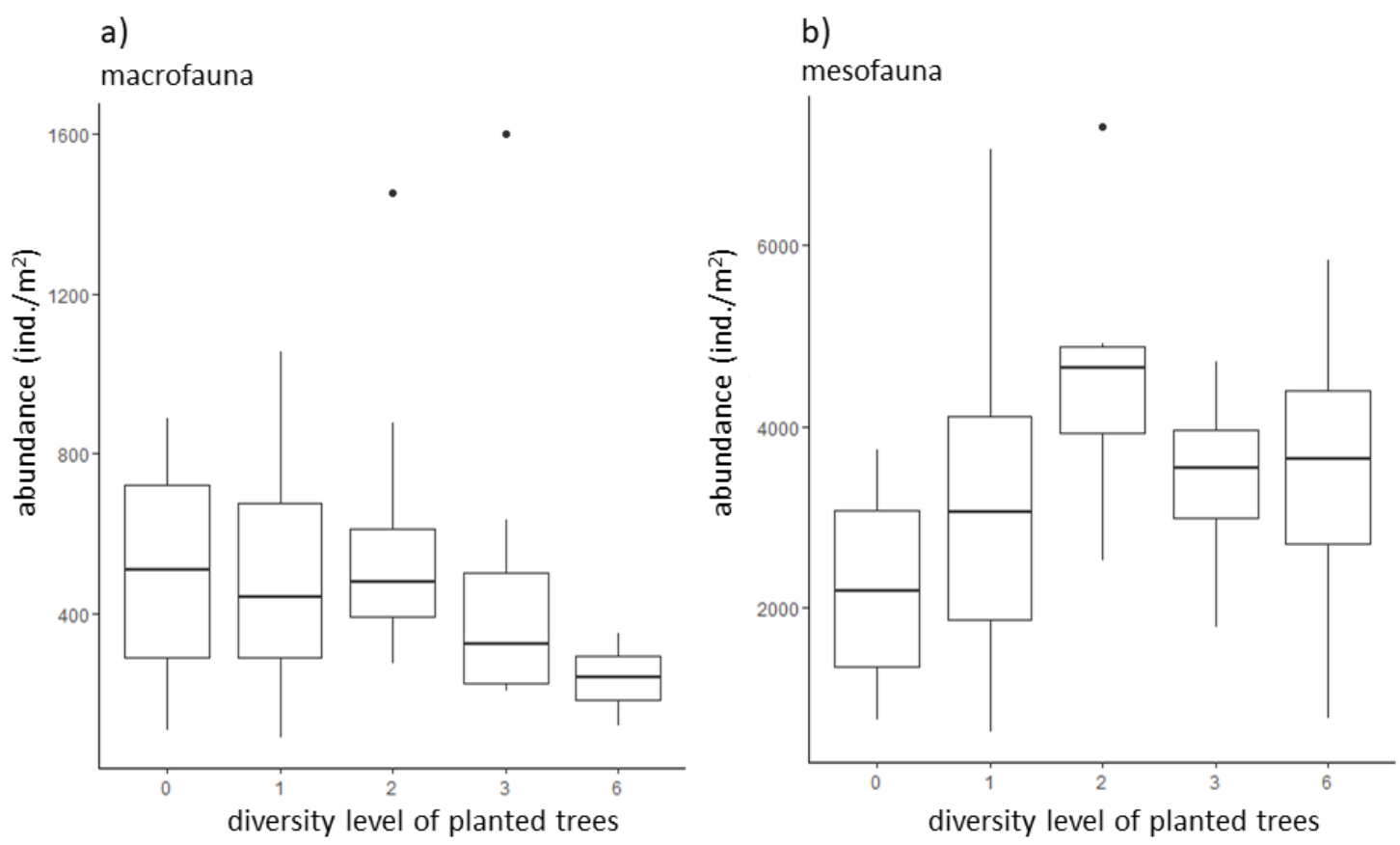

Figure 1: Abundance of macrofauna (a) and mesofauna (b) at the five tree diversity levels $(0,1,2$, 3 and 6). Note the different scales. Differences between means in both analyses were not significant, anova $\mathrm{p}>0.05$.

Plot size also did not significantly affect the abundance of macro- and mesofauna $\left(F_{3,48}=\right.$ 1.19, $p=0.3244$ and $F_{3,48}=1.23, p=0.3092$, respectively). Although not significant, macrofauna abundance was similar in $20 \times 20$ and $40 \times 40 \mathrm{~m}$ and lower in $10 \times 10$ and $5 \times$ $5 \mathrm{~m}$ plots (Figure 2a; for detailed information see Table S4). Mesofauna abundance was similar in each of the plots of different size (Figure $2 b$; for detailed information see Table S4). 
a)

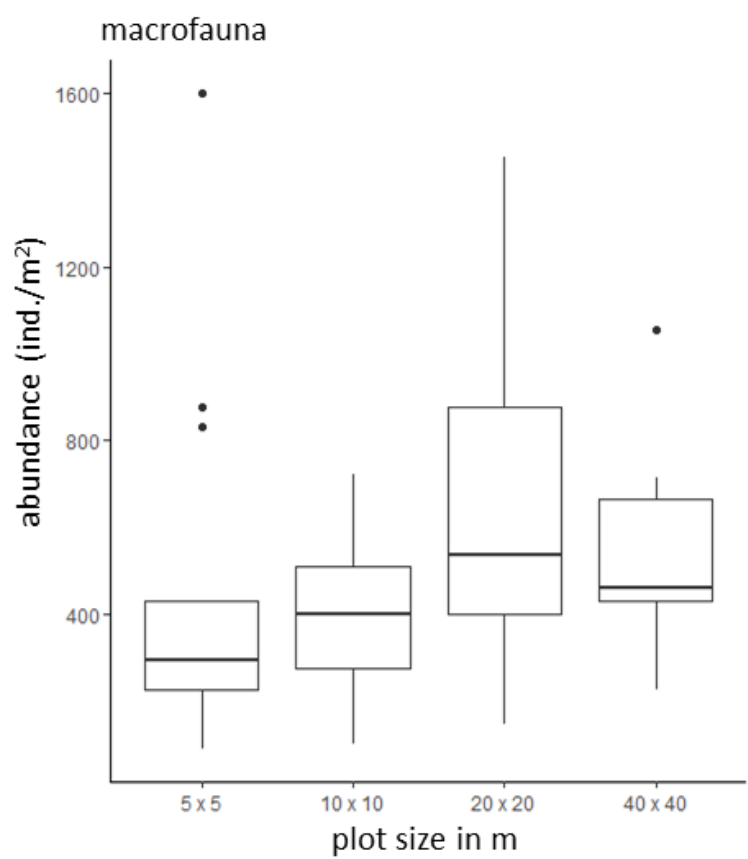

b)

mesofauna

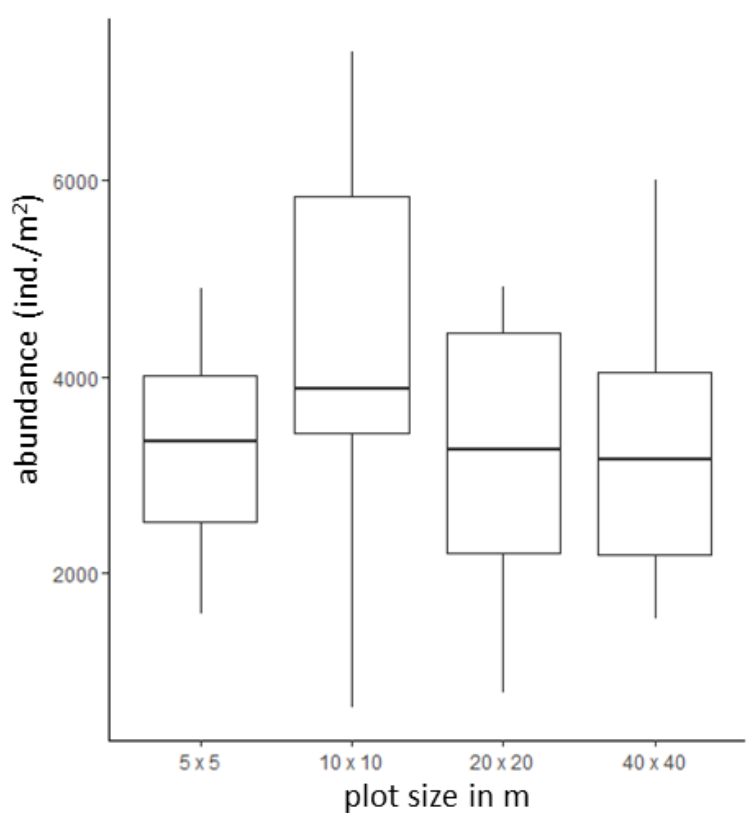

Figure 2: Abundance of macrofauna (a) and mesofauna (b) at the four plot sizes $(5 \times 5,10 \times 10,20$ x 20 and $40 \times 40 \mathrm{~m}$ ). Note the different scales. Differences between means in both analyses were not significant, anova $\mathrm{p}>0.05$.

\section{Richness of macro- and mesofauna taxa}

Richness of macrofauna taxa varied significantly with tree diversity $\left(F_{1,50}=4.29 ; p=0.027\right)$, whereas richness of mesofauna taxa were not significant (Figure 3; for detailed information see Table S5). Macrofauna richness was highest at diversity level 2, lowest at diversity level 6 and intermediate at diversity levels 0, 1 and 3 (Figure 3a). Mesofauna richness was similar at all diversity levels (Figure 3b). 

a) macrofauna
b) mesofauna
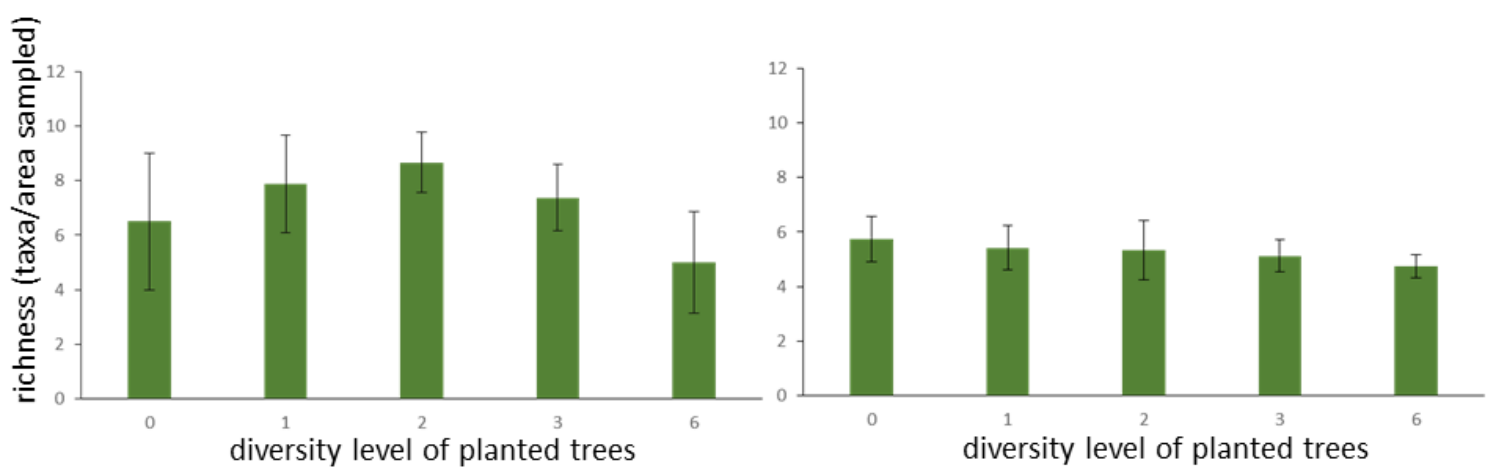

Figure 3: Richness of macrofauna (a) and mesofauna (b) at five tree diversity levels (0, 1, 2, 3 and 6) of the area sampled per plot, i.e. $1024 \mathrm{~cm}^{2}$. Means with standard deviation.

Macro- and mesofauna richness did not vary significantly with plot size $\left(F_{3,48}=0.71, p=\right.$ 0.55 and $F_{3,48}=1.53, p=0.219$, respectively) (Figure 4; for detailed information see Table S6). Although not significant, macrofauna richness was highest at plot size $20 \times 20 \mathrm{~m}$, similar at plot size $40 \times 40 \mathrm{~m}, 10 \times 10 \mathrm{~m}$ and $5 \times 5 \mathrm{~m}$ (Figure 4a). Mesofauna richness of soil invertebrate taxa was similar at plot size $5 \times 5 \mathrm{~m}$ and $20 \times 20 \mathrm{~m}$ and slightly lower at plot size $10 \times 10 \mathrm{~m}$ and $40 \times 40 \mathrm{~m}$ (Figure 4b). 
a) macrofauna

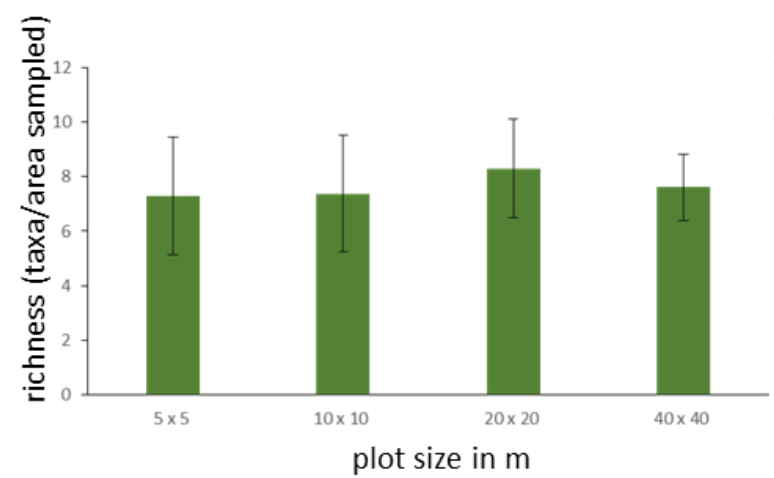

b) mesofauna

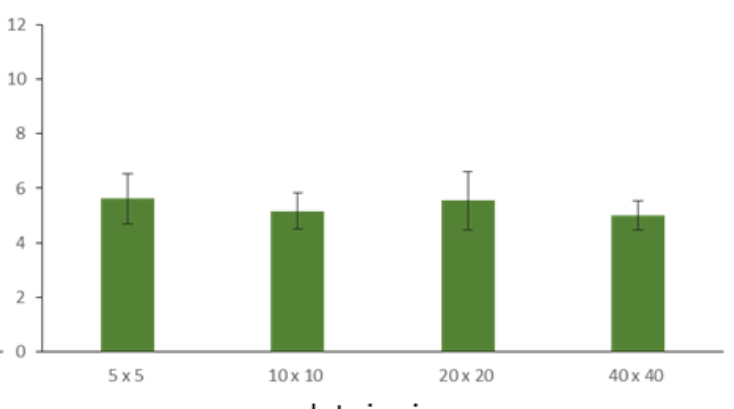

plot size in $\mathrm{m}$

Figure 4: Richness of macrofauna (a) and mesofauna (b) at the four plot sizes $(5 \times 5,10 \times 10,20 \times$ 20 and $40 \times 40 \mathrm{in} \mathrm{m}$ ) of the area sampled per plot, i.e. $1024 \mathrm{~cm}^{2}$. Means with standard deviation.

\section{Community structure}

In total, 21,270 individuals of 25 taxa (Table S2) were identified. Only Collembola and Oribatida occurred at each diversity level of planted trees and plot size. None of the taxa occurred exclusively at only one tree diversity level.

The first two axes of the PCA accounted for a total of $39.2 \%$ of the variation in taxa data (Figure 5). The first axis (PC1) accounted for the majority of the variability (21.0\%) and separated diversity level 2 from the other four diversity levels $(0,1,3$ and 6$)$. The second axis (PC2) accounted for $18.2 \%$ and separated diversity levels 2 and 1 from diversity levels 0, 3 and 6. Taxa associated with diversity level 2 were mostly decomposers, including Collembola, Oribatida, Symphyla and Diplopoda, and two predatory taxa, i.e. Mesostigmata and Chilopoda. Taxa associated with the other four diversity levels of planted tree species $(0,1,3$ and 6$)$ were mostly predators, including predatory Coleoptera, Opiliones and Schizomida, and one decomposer taxon, i.e. Annelida. Along the second axis diversity level 1 was mostly associated with predators, including Pseudoscorpiones, 
Araneae and Diplura (Campodidae) and one decomposer taxon, i.e. Annelida. By contrast, diversity level 2 was mostly associated with decomposer taxa, including Oribatida, Collembola and Symphyla. Taxa associated with diversity level 3 were Opiliones and Schizomida, with diversity level 6 it was predatory Coleoptera and with diversity level 0 is was Thysanoptera.

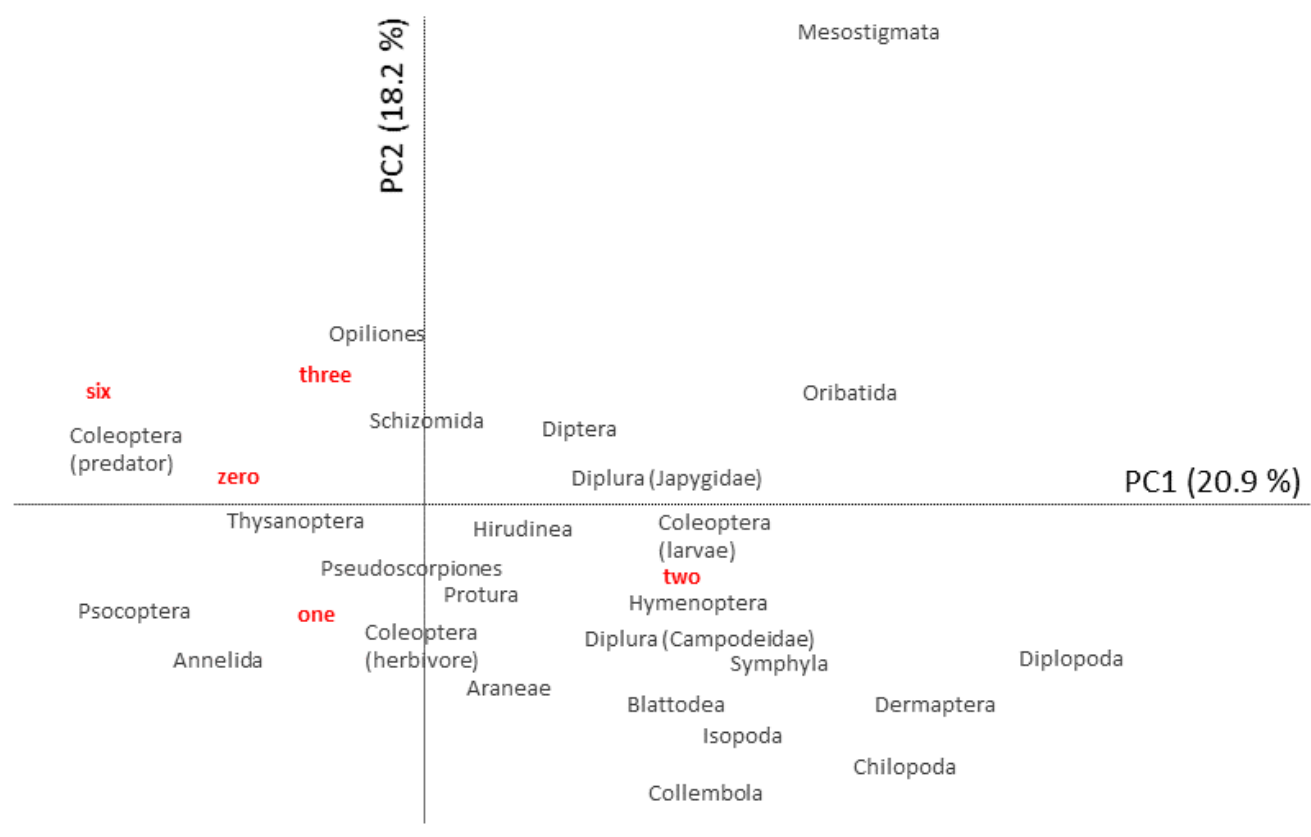

Figure 5: Principal components analysis (PCA) of the community composition of soil invertebrate taxa. Tree diversity levels (0, 1, 2, 3 and 6) were included as passive variables (red). The first axis (PC1) represents $20.9 \%$ and the second (PC2) $18.2 \%$ of the variability in taxa data; the length of gradient is 1.2. Data were log-transformed prior to the analysis. 


\section{Discussion}

\section{Abundance of macro- and mesofauna}

Neither the diversity of planted tree species nor plot size significantly affected the abundance of macro- and mesofauna taxa. These findings contrast results of earlier studies showing that increased coverage of plants, due to a reduction of herbicide use, beneficially affects aboveground invertebrates (Chung et al., 2000; Ashton-Butt et al., 2018; Spear et al., 2018; Darras et al., 2019). In contrast to these results, bird diversity and bird abundance have been shown to increase with increasing number of planted trees in oil palm plantations (Teuscher et al., 2015). However, plant diversity effects have been found to dampen at higher trophic level and with the degree of omnivory of consumers, and this was true for both abundance and richness of above- and belowground organisms (Scherber et al., 2010). Results of the study of Scherber et al. (2010) further showed the response of belowground organisms to plant diversity to be less pronounced compared to that of aboveground organisms. In particular herbivore species responded more strongly to changes in plant diversity than predator and omnivore species. Also, alley-cropping, i.e. planting a mosaic of tree, grass and/or shrubs species into cropland (Gold and Garrett., 2009), has been shown to impact aboveground arthropod diversity; larger numbers of predators and decomposers occurred at sites with alley-cropping (Ashraf et al., 2018). Plant diversity effects on soil biota have been shown to strongly depend on time and only occur after a pronounced time lag of four to six years after manipulating plant species diversity (Eisenhauer et al., 2011). This suggests that three years after the establishment of plant communities of different diversity in the present study might have been too short for macro- and mesofauna soil invertebrate taxa to respond to the established 
experimental treatments. Castillo et al. (2018) showed that abundance and species richness of oribatid mites changed due to reforestation of pastureland in tropical montane forest in Ecuador after seven years, but the changes still were little pronounced. Supporting the conclusion that soil invertebrates respond to changes in plant community composition with a pronounced lime lag, Teuscher et al. (2016) found significant effects of planting trees as well as plot size on bird and aboveground invertebrate species one year after the establishment of the experiment. Aboveground invertebrates associated with the herb-layer increased slightly compared to the control plots. Further, contrasting the findings of the present study, aboveground invertebrates also responded to plot size already one year after the establishment of the experiment (Teuscher et al., 2016). This likely reflects the more close association of aboveground animals, in particular herbivores, with plant species and associated changes in environmental factors and habitat structure (Tscharntke et al., 2011; Pywell et al., 2012; Teuscher et al., 2016). Supporting our findings, earlier studies showed that physical habitat characteristics might be more important drivers for belowground soil invertebrate communities than the diversity and identity of planted trees (Ducarme et al., 2004; Nielsen et al., 2010; Bluhm et al., 2019). However, physical habitat characteristics also change with changes in tree diversity and identity but these changes are slow and need to be investigated in long-term studies (Bluhm et al., 2019).

\section{Richness of macro- and mesofauna taxa}

Confirm to our hypothesis, the richness of macrofauna taxa varied with the diversity of planted tree species; it was at a maximum at diversity level 2 , whereas it was at a minimum 
at diversity level 6 . Similar to these findings, it has been demonstrated that aboveground arthropod diversity and richness increase in oil palm plantations with alley-cropping (Azhar et al., 2014; Ashraf et al., 2018). Alley-cropping includes a variety of crop plants and trees which increase habitat heterogeneity, soil fertility, water quality as well as carbon and nutrient cycling (Fahrig et al., 2011; Torralba et al., 2016; Ashraf et al., 2018). Additionally, it enhances the complexity of the vegetation and thereby the number and size of microhabitats (Lawton, 1983; Jose, 2009). Oil palm plantations generally lack a diverse understory, and herbicides as well as fertilizer use is high (Ismail et al., 2009). Similar to Alley-cropping, the enrichment of oil palm plantations with native tree species and the reduced fertilizer and herbicide use may increase resource availability and thereby increase the diversity of micohabitats.

Richness as well as abundance of macro- and mesofauna taxa did not significantly respond to variations in plot size. These findings are consistent with results of earlier studies indicating that species richness may not vary in a consistent way with island area (Brose, 2003; Báldi, 2008; Jonsson et al., 2009). The study of Brose (2003) demonstrated that habitat area did not affect species richness of wetland carabid beetle communities in agricultural landscapes in northern Germany. Báldi (2008) demonstrated that habitat heterogeneity may in fact decrease with habitat size and species-area relationship were not significant for nine out of eleven studied taxa including Collembola, Oribatida and Chilopoda. Jonsson et al. (2009) also found the diversity of belowground invertebrates of the boreal zone of northern Sweden to be rather insensitive to changes in island size or isolation. 


\section{Community structure}

Community analysis showed that taxa associated with diversity level 2 and 1 were primarily decomposers, whereas taxa associated with diversity levels 0,3 and 6 were primarily predators. This suggests that decomposer invertebrates benefitted from increased litter input and the formation of a litter layer in plantations of low tree species richness. Potentially, higher tree diversity counteracted the accumulation of litter in the litter layer by facilitating litter decomposition. In fact, it has been shown that litter mixtures may decompose much faster than single litter species or mixtures of low species richness (Hättenschwiler et al., 2005; Benbow et al., 2015). On the contrary, predator taxa such as cursorial spiders may benefit from more open habitats facilitating prey capture (Wise, 1995; Lawrence and Wise, 2000). If true, this implies that low diversity levels of tree species are associated with low nutrient recycling hampering primary production with important feedbacks to the belowground system. Potentially, in the long-term tree plantations of low diversity may be associated by a depauperated soil biota community (Wardle, 2006; Wardle et al., 2006). However, the traits of plant and litter species responsible for changes in soil animal communities associated with changes in plant species are little understood (Wardle, 2006), but the changes are likely driven by changes in litter quality (Díaz et al., 2004; Wardle, 2006) but also by changes in the physical structure of litter (Hansen, 1999; Wardle, 2006; Wardle et al., 2006). Supporting our conclusion that predators may benefit from more open habitats with shallow litter layers, results of earlier studies on Oribatida and Chilopoda indicate that monoculture plantations, such as rubber and oil palm, favor predators and/or scavengers (Klarner et al., 2017; Krause et al., 2019, A. Krause unpublished data 2020). Another study showed 
that soil porosity and $\mathrm{pH}$ are the main drivers of oribatid mite abundance and richness, indicating that physical habitat characteristics might override food resources as driving factors for soil animal communities (Ducarme et al., 2004).

Overall, the results of the present study indicate that the enrichment of oil palm plantation with native trees may contribute to the formation of more complex decomposer communities, but further long-term studies with a wider range of tree species are needed to explore the factors responsible for changes in soil communities increasing the functioning of plantation systems. Enrichment of oil palm plantations with native trees is a promising option to enhance biodiversity of existing monoculture plantations and to develop more sustainable management strategies.

\section{Conclusions}

The decline in biomass of arthropod species in temperate and tropical regions are driven in the first place by changes in land use. Alternative management practices of agricultural systems therefore are receiving increased attention. However, since soil formation processes are slow, effects of the enrichment of plantation systems with native trees for soil invertebrate taxa are likely to be delayed. Three years after the establishment of enrichment planting soil invertebrate abundance did not change significantly. However, soil invertebrate richness increased at intermediate tree diversity level, indicating that resource availability peaks at intermediate diversity level. Presumably, additive mixture effects increase litter decomposition thereby increasing food quality for litter feeding macrofauna. Long-term experiments are needed to more fully explore the response of soil 
animal communities to the enrichment of plantation systems with native trees species and the feedbacks to the functioning of the plantations.

\section{Acknowledgments}

\section{Funding}

This study was funded by the Deutsche Forschungsgemeinschaft (DFG, German Research Foundation) - project number 192626868 - SFB 990 (and/or the Ministry of Research, Technology and Higher Education (Ristekdikti)) in the framework of the collaborative German - Indonesian research project CRC990.

\section{Field work permissions}

The study was conducted in the framework of the German-Indonesian research project "Ecological and socio-economic functions of tropical lowland rainforest transformation systems" (EFForTS) based on the research permits no. 343/SIP/FRP/E5/Dit.KI/X/2016, issued by the State Ministry of Research and Technology of the Republic of Indonesia (RISTEK). Samples were based on collection permit no. S.1006/KKH/SDG/KSA.2/10/2016 issued by the Indonesian Ministry of Forestry (PHKA). Sample export for analysis in Germany was based on permit no. SK.337/KSDAE/SET/KSA.2/7/2019 issued by the Ministry of Forestry of the Republic of Indonesia. 


\section{Sample collection and determination}

We thank Di Ajeng Prameswari, Hanif Fataroh, Hilman, Julia Schulz, Leonarda Situmorang, Marisi Italiansia Paulina and Mohamad Suheri for help in sorting soil animals and the transport of animals from Indonesia to Germany.

\section{References}

Allen, K., Corre, M.D., Tjoa, A., Veldkamp, E., 2015. Soil nitrogen-cycling responses to conversion of lowland forests to oil palm and rubber plantations in Sumatra, Indonesia. PLOS ONE 10, 1-21.

Ashraf, M., Zulkifli, R., Sanusi, R., Tohiran, K.A., Terhem, R., Moslim, R., Norhisham, A.R., Ashton-Butt, A., Azhar, B., 2018. Alley-cropping system can boost arthropod biodiversity and ecosystem functions in oil palm. Agriculture, Ecosystems \& Environment 260, 19-26.

Ashton-Butt, A., Aryawan, A.A., Hood, A.S., Naim, M., Purnomo, D., Suhardi, S., Wahyuningsih, R., Willcock, S., Poppy, G.M., Caliman, J., Turner, E.C., Foster, W., Peh, K.S., Snaddon, J.L., 2018. Understory vegetation in oil palm plantations benefits soil biodiversity and decomposition rates. Frontier in Forest and Global Change 1, 10.

Azhar, B., Puan, C.L., Zakaria, M., Assan, N., Arif, M., 2014. Effects of monoculture and polyculture practices in oil palm smallholdings on tropical farmland birds. Basic and Applied Ecology 15, 336-346.

Báldi, A., 2008. Habitat heterogeneity overrides the species-area relationship. Journal of Biogeography 35, 675-681.

Bardgett, R., 2005. The biology of soil: A community and ecosystem approach. Oxford University Press.

Barnes, A.D., Jochum, M., Mumme, S., Haneda, N.F., Farajallah, A., Widarto, T.H., Brose, U., 2014. Consequences of tropical land use for multitrophic biodiversity and ecosystem functioning. Nature Communications 5, 1-7.

Bell, T., Lilley, A.K., Hector, A., Schmid, B., King, L., Newman, J.A., 2009. A linear model method for biodiversity-ecosystem functioning experiments. The American Naturalist $174,836-849$.

Benbow, M.E., Tomberlin, J.K., Tarone, A.M., 2015. Introduction to carrion ecology, evolution, and their applications, in: Carrion Ecology, Evolution, and Their Applications. CRC Press, Boca Raton, USA, pp. 3-12.

Berg, B., McClaugherty, C., 2008. Plant Litter: Decomposition, humus formation carbon sequestration. Springer-Verlag Heidelberg.

Bessou, C., Verwilghen, A., Beaudoin-Ollivier, L., Marichal, R., Ollivier, J., Baron, V., Bonneau, X., Carron, M.-P., Snoeck, D., Naim, M., Ketuk Aryawan, A.A., Raoul, F., Giraudoux, P., Surya, E., Sihombing, E., Caliman, J.-P., 2017. Agroecological practices in oil palm plantations: Examples from the field. Ocl, Oilseeds and Fats, Crops and Lipids 24. 
Bluhm, C., Butenschoen, O., Maraun, M., Scheu, S., 2019. Effects of root and leaf litter identity and diversity on oribatid mite abundance, species richness and community composition. PLOS ONE 14, e0219166.

Bridges, E.M., Oldeman, L.R., 1999. Global assessment of human-induced soil degradation. Arid Soil Research and Rehabilitation 13, 319-325.

Brose, U., 2003. Island biogeography of temporary wetland carabid beetle communities. Journal of Biogeography $30,879-888$.

Brussaard, L., Pulleman, M.M., Ouédraogo, É., Mando, A., Six, J., 2007. Soil fauna and soil function in the fabric of the food web. Pedobiologia 50, 447-462.

Carter, C., Finley, W., Fry, J., Jackson, D., Willis, L., 2007. Palm oil markets and future supply. European Journal of Lipid Science and Technology 109, 307-314.

Castillo, P.R., Marian, L., Marian, F., Günter, S., Espinosa, C.I., Maraun, M., Scheu, S., 2018. Response of oribatid mites to reforestation of degraded tropical montane pastureland. European Journal of Soil Biology 84, 34-41.

Chambers, J.M., Hastie, T.J., 1992. Linear models, in: Hastie, T.. (Ed.), Statistical Models in S. Pacific Grove, CA: Wadsworth \& Brooks/Cole Advanced Books \& Software.

Chazdon, R.L., 2008. Beyond Deforestation: Restoring forest and ecosystem services on degraded lands. Science 320, 1458-1460.

Chung, A.Y.C., Eggleton, P., Speight, M.R., Hammond, P.M., Chey, V.K., 2000. The diversity of beetle assemblages in different habitat types in Sabah, Malaysia. Bulletin of Entomological Research 90, 475496.

Clay, J., 2013. World agriculture and the environment: A commodity-by-commodity guide to impacts and practices. Island Press.

Corbin, J.D., Holl, K.D., 2012. Applied nucleation as a forest restoration strategy. Forest Ecology and Management 265, 37-46.

Coûteaux, P., Bottner, M.-M., Berg, B., 1995. Litter decomposition, climate and liter quality. Trends in Ecology \& Evolution 12.2, 63-66.

Curran, L.M., Trigg, S.N., Mcdonald, A.K., Astiani, D., Hardiono, Y.M., Siregar, P., Caniago, I., Kasischke, E., 2004. Lowland forest loss in protected areas. Science 303, 1000-1003.

Darras, K., Corre, M.D., Formaglio, G., Tjoa, A., Potapov, A., Sibhatu, K.T., Grass, I., Tscharntke, T., Rubiano, A.A., Buchori, D., Drescher, J., Fardiansah, R., Hölscher, D., Irawan, B., Kneib, T., Krashevska, V., Krause, A., Kreft, H., Li, K., Polle, A., Ryadin, A.R., Rembold, K., Scheu, S., 2019. Reducing fertilizer and avoiding herbicides in oil palm plantations - Ecological and economic valuation. Frontiers in Forests and Global Change 265.

Dennis, R.A., Mayer, J., Applegate, G., Chokkalingam, U., Colfer, C.J.P., Kurniawan, I., Lachowski, H., Maus, P., Permana, R.P., Ruchiat, Y., Stolle, F., Suyanto, Tomich, T.P., 2005. Fire, people and pixels: Linking social science and remote sensing to understand underlying causes and impacts of fires in Indonesia. Human Ecology 33, 465-504. 
Díaz, S., Hodgson, J.G., Thompson, K., Cabido, M., J.H., C., Jalili, A., Montserrat-Marti, G., Grime, J.P., Zarrinkamar, F., Asri, Y., Band, S.R., 2004. The plant traits that drive ecosystems: Evidence from three continents. Journal of Vegetation Science 15, 295-304.

Dirzo, R., Raven, P.H., 2003. Global state of biodiversity and loss. Annual Review of Environment and Resources 28, 137-167.

Drescher, J., Rembold, K., Allen, K., Beckscha, P., Buchori, D., Clough, Y., Faust, H., Fauzi, A.M., Gunawan, D., Hertel, D., Irawan, B., Jaya, I.N.S., Klarner, B., Kleinn, C., Knohl, A., Kotowska, M.M., Krashevska, V., Krishna, V., Leuschner, C., Lorenz, W., Meijide, A., Melati, D., Steinebach, S., Tjoa, A., Tscharntke, T., Wick, B., Wiegand, K., Kreft, H., Scheu, S., 2016. Ecological and socio-economic functions across tropical land use systems after rainforest conversion. Philosophical Transactions of the Royal Society of London. Series B, Biological Sciences 231, 1-7.

Ducarme, X., André, H.M., Wauthy, G., Lebrun, P., 2004. Are there real endogeic species in temperate forest mites? Pedobiologia 48, 139-147.

Edwards, F.A., Edwards, D.P., Larsen, T.H., Hsu, W.W., Benedick, S., Chung, A., Vun Khen, C., Wilcove, D.S., Hamer, K.C., 2014. Does logging and forest conversion to oil palm agriculture alter functional diversity in a biodiversity hotspot? Animal Conservation 17, 163-173.

Eisenhauer, N., Beßler, H., Engels, C., Gleixner, G., Habekost, M., Milcu, A., Partsch, S., Sabais, A.C.W., Scherber, C., Steinbeiss, S., Weigelt, A., Weisser, W.W., Scheu, S., 2010. Plant diversity effects on soil microorganisms support the singular hypothesis. Ecology 91, 485-496.

Eisenhauer, N., Milcu, A., Sabais, A.C.W., Bessler, H., Brenner, J., Engels, C., Klarner, B., Maraun, M., Partsch, S., Roscher, C., Schonert, F., Temperton, V.M., Thomisch, K., Weigelt, A., Weisser, W.W., Scheu, S., 2011. Plant diversity surpasses plant functional groups and plant productivity as driver of soil biota in the long term. PLOS ONE 6, 15-18.

Eisenhauer, N., Milcu, A., Sabais, A.C.W., Bessler, H., Weigelt, A., Engels, C., Scheu, S., 2009. Plant community impacts on the structure of earthworm communities depend on season and change with time. Soil Biology and Biochemistry 41, 2430-2443.

Ettema, C.H., Wardle, D.A., 2002. Spatial soil ecology. Trends in Ecology \& Evolution 17.4, 177-183.

Fahrig, L., Baudry, J., Brotons, L., Burel, F.G., Crist, T.O., Fuller, R.J., Sirami, C., Siriwardena, G.M., Martin, J.L., 2011. Functional landscape heterogeneity and animal biodiversity in agricultural landscapes. Ecology Letters 14, 101-112.

Fitzherbert, E.B., Struebig, M.J., Morel, A., Danielsen, F., Brühl, C.A., Donald, P.F., Phalan, B., 2008. How will oil palm expansion affect biodiversity? Trends in Ecology and Evolution 23, 538-545.

Foley, J.A., Ramankutty, N., Brauman, K. a., Cassidy, E.S., Gerber, J.S., Johnston, M., Mueller, N.D., O'Connell, C., Ray, D.K., West, P.C., Balzer, C., Bennett, E.M., Carpenter, S.R., Hill, J., Monfreda, C., Polasky, S., Rockström, J., Sheehan, J., Siebert, S., Tilman, D., Zaks, D.P.M., 2011. Solutions for a cultivated planet. Nature 478, 337-342.

Foley, J.A., Defries, R., Asner, G.P., Barford, C., Bonan, G., Carpenter, S.R., Chapin, S.F., Coe, M.T., Daily, G.C., Gibbs, H.K., Helkowski, J.H., Holloway, T., Howard, E.A., Kucharik, C.J., Monfreda, C., Patz, J.A., Prentice, C.I., Ramankutty, N., Snyder, P.K., 2005. Global consequences of land use. Science 309, 570574. 
Foster, W.A., Snaddon, J.L., Turner, E.C., Fayle, T.M., Cockerill, T.D., Farnon Ellwood, M.D., Broad, G.R., Chung, A.Y.C., Eggleton, P., Khen, C.V., Yusah, K.M., 2011. Establishing the evidence base for maintaining biodiversity and ecosystem function in the oil palm landscapes of South East Asia. Philosophical Transactions of the Royal Society B: Biological Sciences 366, 3277-3291.

Francini, G., Hui, N., Jumpponen, A., Kotze, D.J., Romantschuk, M., Allen, J. a., Setälä, H., 2018. Soil biota in boreal urban greenspace: Responses to plant type and age. Soil Biology and Biochemistry 118, 145155.

Gibbs, H.K., Ruesch, A.S., Achard, F., Clayton, M.K., Holmgren, P., Ramankutty, N., Foley, J.A., 2010. Tropical forests were the primary sources of new agricultural land in the 1980s and 1990s. Proceedings of the National Academy of Sciences of the USA 107, 16732-16737.

Godfray, H.C.J., Beddington, J.R., Crute, I.R., Haddad, L., Lawrence, D., Muir, J.F., Pretty, J., Robinson, S., Thomas, S.M., Toulmin, C., 2010. Food Security: The challenge of feeding 9 billion people 327, 812818.

Gold, M.A., Garrett., H.E., 2009. Agroforestry nomenclature, concepts, and practices, in: North American Agroforestry: An Integrated Science and Practice. northamericanag, pp. 45-56.

Handa, I.T., Aerts, R., Berendse, F., Berg, M.P., Bruder, A., Butenschoen, O., Chauvet, E., Gessner, M.O., Jabiol, J., Makkonen, M., McKie, B.G., Malmqvist, B., Peeters, E.T.H.M., Scheu, S., Schmid, B., Van Ruijven, J., Vos, V.C.A., Hättenschwiler, S., 2014. Consequences of biodiversity loss for litter decomposition across biomes. Nature 509, 218-221.

Hansen, R.A., 1999. Red oak litter promotes a microarthropod functional group that accelerates its decomposition. Plant and Soil 209, 37-45.

Hättenschwiler, S., Tiunov, A.V., Scheu, S., 2005. Biodiversity and litter decomposition in terrestrial ecosystems. Annual Review of Ecology, Evolution, and Systematics 36, 191-218.

Hedlund, K., Regina, I.S., Van Der Putten, W.H., Lepš, J., Díaz, T., Korthals, G.W., Lavorel, S., Brown, V.K., Gormsen, D., Mortimer, S.R., Barrueco, C.R., Roy, J., Smilauer, P., Smilauerová, M., Van Dijk, C., 2003. Plant species diversity, plant biomass and responses of the soil community on abandoned land across Europe: Idiosyncracy or above-belowground time lags. Oikos 103, 45-58.

Hooper, D.U., Bignell, D.E., Brown, V.K., Lavelle, P., Van der Putten, W.H., de Ruiter, P.C., Rusek, J., Silver, W.L., Tiedje, J.M., Wolters, V., 2000. Aboveground and belowground biodiversity in terrestrial ecosystems: Patterns, mechanisms, and feedbacks. Bioscience 50, 1049-1061.

Ismail, S., Khasim, N., Omar, Z.R., 2009. Double-row avenue system for crop integration with oil palm. MPOB Information Series 1-4.

Jones, G., 2013. The population of Southeast Asia. Routledge Handbook of Southeast Asian Economics. Routledge, 2014. 223-251.

Jonsson, M., Yeates, G.W., Wardle, D.A., 2009. Patterns of invertebrate density and taxonomic richness across gradients of area, isolation, and vegetation diversity in a lake-island system. Ecography 32, 963972.

Jose, S., 2009. Agroforestry for ecosystem services and environmental benefits: An overview. Agroforestry Systems 76, 1-10.

Kempson, D., Monte, L., Ghelardi, R., 1963. A new extractor for woodland litter. Pedobiologia 3, 1-21. 
Klarner, B., Winkelmann, H., Krashevska, V., Maraun, M., Widyastuti, R., Scheu, S., 2017. Trophic niches, diversity and community composition of invertebrate top predators (Chilopoda) as affected by conversion of tropical lowland rainforest in Sumatra (Indonesia). PLOS ONE 1-17.

Koh, L.P., Levang, P., Ghazoul, J., Bhagwat, S.A., Willis, K.J., 2009. Designer landscapes for sustainable biofuels. Trends in Ecology \& Evolution 24, 431-438.

Krause, A., Sandmann, D., Bluhm, S.L., Ermilov, S., Widyastuti, R., Haneda, N.F., Scheu, S., Maraun, M., 2019. Shift in trophic niches of soil microarthropods with conversion of tropical rainforest into plantations as indicated by stable isotopes $\left({ }^{15} \mathrm{~N},{ }^{13} \mathrm{C}\right)$. PLOS ONE 14.10.

Lambin, E.F., Meyfroidt, P., 2011. Global land use change, economic globalization, and the looming land scarcity. Proceedings of the National Academy of Sciences of the United States of America 108, 34653472.

Lawrence, K.L., Wise, D.H., 2000. Spider predation on forest-floor Collembola and evidence for indirect effects on decomposition. Pedobiologia. 44.1, 33-39.

Lawton, J.H., 1983. Plant architecture and the diversity of phytophagous insects. Annual Review of Entomology 28, 23-39.

Legendre, P., Fortin, M.-J., 1989. Spatial pattern and ecological analysis. Vegetatio 80, 107-138.

Luskin, M.S., Potts, M.D., 2011. Microclimate and habitat heterogeneity through the oil palm lifecycle. Basic and Applied Ecology 12, 540-551.

MacArthur, R.H., Wilson, E.O., 1967. The theory of island biogeography. Princeton University Press.

MacArthur, R.H., Wilson, E.O., 1963. An equilibrium theroy of insular zoogeography. Evolution 17, 373-387.

Margono, B.A., Potapov, P.V., Turubanova, S., Stolle, F., Hansen, M.C., 2014. Primary forest cover loss in indonesia over 2000-2012. Nature Climate Change 4, 730-735.

McNaughton, S.J., Oesterheld, M., Frank, D.A., Williams, K.J., 1989. Ecosystem-level patterns of primary productivity and herbivory in terrestrial habitats. Nature 341, 142-144.

Meijide, A., Badu, C.S., Moyano, F., Tiralla, N., Gunawan, D., Knohl, A., 2018. Impact of forest conversion to oil palm and rubber plantations on microclimate and the role of the 2015 ENSO event. Agricultural and Forest Meteorology 252, 208-2019.

Mendenhall, C.D., Karp, D.S., Meyer, C.F.J., Hadly, E. a., Daily, G.C., 2014. Predicting biodiversity change and averting collapse in agricultural landscapes. Nature 509, 213-217.

Milcu, A., Partsch, S., Scherber, C., Weisser, W.W., Scheu, S., 2008. Earthworms and legumes control litter decomposition in a plant diversity gradient. Ecology 89, 1872-1882. 
Newbold, T., Hudson, L.N., Hill, S.L.L., Contu, S., Lysenko, I., Senior, R.A., Börger, L., Bennett, D.J., Choimes, A., Collen, B., Day, J., De Palma, A., Díaz, S., Echeverria-Londoño, S., Edgar, M.J., Feldman, A., Garon, M., Harrison, M.L.K., Alhusseini, T., Ingram, D.J., Itescu, Y., Kattge, J., Kemp, V., Kirkpatrick, L., Kleyer, M., Correia, D.L.P., Martin, C.D., Meiri, S., Novosolov, M., Pan, Y., Phillips, H.R.P., Purves, D.W., Robinson, A., Simpson, J., Tuck, S.L., Weiher, E., White, H.J., Ewers, R.M., MacE, G.M., Scharlemann, J.P.W., Purvis, A., 2015. Global effects of land use on local terrestrial biodiversity. Nature 520, 45-50.

Nielsen, U.N., Osler, G.H.R., Campbell, C.D., Neilson, R., Burslem, D.F.R.P., van der Wal, R., 2010. The enigma of soil animal species diversity revisited: The role of small-scale heterogeneity. PLOS ONE 5, 26-28.

Nielsen, U.N., Wall, D.H., Six, J., 2015. Soil biodiversity and the environment. Annual Review of Environment and Resources 40, 63-90.

Nurdiansyah, F., Denmead, L.H., Clough, Y., Wiegand, K., Tscharntke, T., 2016. Biological control in Indonesian oil palm potentially enhanced by landscape context. Agriculture, Ecosystems \& Environment 232, 141-149.

Pavao-Zuckerman, M.A., Sookhdeo, C., 2017. Nematode community response to green infrastructure design in a semiarid city. Journal of Environmental Quality 46, 687-694.

Potapov, A.M., Tiunov, A.V., Scheu, S., 2019. Uncovering trophic positions and food resources of soil animlas using bulk natural stable isotope composition. Biological Reviews 94, 37-59.

Pywell, R.F., Heard, M.S., Bradbury, R.B., Hinsley, S., Nowakowski, M., Walker, K.J., Bullock, J.M., 2012. Wildlife-friendly farming benefits rare birds, bees and plants. Biology Letters 8, 772-775.

R Core Team, 2018. R: A language and environment for statistical computing. R Foundation for Statistical Computing.

Reynolds, J.F., Smith, D.M.S., Mortimore, M., Herrick, J.E., Downing, T.E., Batterbury, S.P.J., Maestre, F.T., Huber-Sannwald, E., Turner, B.L., Dowlatabadi, H., Walker, B., Ayarza, M., Reynolds, J.F., Leemans, R., Lambin, E.F., Lynam, T., Jiang, H., Fernandez, R.J., 2007. Global desertification: Building a science for dryland development. Science 316, 847-851.

Scherber, C., Eisenhauer, N., Weisser, W.W., Schmid, B., Voigt, W., Fischer, M., Schulze, E.D., Roscher, C., Weigelt, A., Allan, E., Beler, H., Bonkowski, M., Buchmann, N., Buscot, F., Clement, L.W., Ebeling, A., Engels, C., Halle, S., Kertscher, I., Klein, A.M., Koller, R., König, S., Kowalski, E., Kummer, V., Kuu, A., Lange, M., Lauterbach, D., Middelhoff, C., Migunova, V.D., Milcu, A., Müller, R., Partsch, S., Petermann, J.S., Renker, C., Rottstock, T., Sabais, A., Scheu, S., Schumacher, J., Temperton, V.M., Tscharntke, T., 2010. Bottom-up effects of plant diversity on multitrophic interactions in a biodiversity experiment. Nature 468, 553-556.

Scherer-Lorenzen, G.A.M., Leadley, P.W., 2003. No consistent effects of plant diversity on root biomass, soil biota and soil abiotic conditions in temperate grassland communities. Applied Soil Ecology 24, 101-111.

Sodhi, N.S., Koh, L.P., Brook, B.W., Ng, P.K., 2004. Southeast Asian biodiversity: An impending disaster. Trends in Ecology and Evolution 19, 654-660.

Sodhi, N.S., Posa, M.R.C., Lee, T.M., Bickford, D., Koh, L.P., Brook, B.W., 2010. The state and conservation of Southeast Asian biodiversity. Biodiversity and Conservation 19, 317-328. 
Spear, D.M., Foster, W. a., Advento, A.D., Naim, M., Caliman, J.P., Luke, S.H., Snaddon, J.L., Ps, S., Turner, E.C., 2018. Simplifying understory complexity in oil palm plantations is associated with a reduction in the density of a cleptoparasitic spider, Argyrodes miniaceus (Araneae: Theridiidae), in host (Araneae: Nephilinae) webs. Ecology and Evolution 8, 1595-1603.

Spehn, E.M., Joshi, J., Schmid, B., Alphei, J., Körner, C., 2000. Plant diversity effects on soil heterotrophic activity in experimental grassland ecosystems. Plant and Soil 224, 217-230.

Susanti, W.I., Pollierer, M.M., Widyastuti, R., Scheu, S., Potapov, A., 2019. Conversion of rainforest to oil palm and rubber plantations alters energy channels in soil food webs. Ecology and Evolution 1-13.

Syafiq, M., Nur Atiqah, A.R., Ghazali, A., Asmah, S., Yahya, M.S., Aziz, N., Puan, C.L., Azhar, B., 2016. Responses of tropical fruit bats to monoculture and polyculture farming in oil palm smallholdings. Acta Oecologica 74, 11-18.

Teuscher, M., Gérard, A., Brose, U., Buchori, D., Clough, Y., Ehbrecht, M., Hölscher, D., Irawan, B., Sundawati, L., Wollni, M., Kreft, H., 2016. Experimental biodiversity enrichment in oil-palmdominated landscapes in Indonesia. Frontiers in Plant Science 07, 1-15.

Teuscher, M., Vorlaufer, M., Wollni, M., Brose, U., Mulyani, Y., Clough, Y., 2015. Trade-offs between bird diversity and abundance, yields and revenue in smallholder oil palm plantations in Sumatra, Indonesia. Biological Conservation 186, 306-318.

Thakur, M.P., Eisenhauer, N., 2015. Plant community composition determines the strength of top-down control in a soil food web motif. Scientific Reports 5, 1-6.

Torralba, M., Fagerholm, N., Burgess, P.J., Moreno, G., Plieninger, T., 2016. Do European agroforestry systems enhance biodiversity and ecosystem services? A meta-analysis. Agriculture, Ecosystems and Environment 230, 150-161.

Tscharntke, T., Clough, Y., Bhagwat, S.A., Buchori, D., Faust, H., Hertel, D., Hölscher, D., Juhrbandt, J., Kessler, M., Perfecto, I., Scherber, C., Schroth, G., Veldkamp, E., Wanger, T.C., 2011. Multifunctional shade-tree management in tropical agroforestry landscapes - A review. Journal of Applied Ecology 48, 619-629.

Tscharntke, T., Clough, Y., Wanger, T.C., Jackson, L., Motzke, I., Perfecto, I., Vandermeer, J., Whitbread, A., 2012. Global food security, biodiversity conservation and the future of agricultural intensification. Biological Conservation 151, 53-59.

UN, 2015. World Population Prospects: The 2015 Revision, Volume I: Comprehensive Tables (ST/ESA/SER:A 379. New York.

Viketoft, M., Bengtsson, J., Sohlenius, B., Berg, M.P., Petchey, O., Palmborg, C., Huss-Danell, K., 2009. Long-term effects of plant diversity and composition on soil nematode communities in model grasslands. Ecology 90, 90-99.

Wardle, D. A., 2006. The influence of biotic interactions on soil biodiversity. Ecology Letters 9, 870-886.

Wardle, D. A., Yeates, G.W., Barker, G.M., Bonner, K.I., 2006. The influence of plant litter diversity on decomposer abundance and diversity. Soil Biology and Biochemistry 38, 1052-1062.

Wickham, H., 2016. ggplot2: Elegant Graphics for Data Analysis. Springer. 
Wilcove, D.S., Giam, X., Edwards, D.P., Fisher, B., Koh, L.P., 2013. Navjot's nightmare revisited: Logging, agriculture, and biodiversity in Southeast Asia. Trends in Ecology and Evolution 28, 531-540.

Wilkinson, G.N., Rogers, C.E., 1973. Symbolic description of factorial models for analysis of variance. Journal of the Royal Statistical Society: Series C (Applied Statistics) 22, 392-399.

Wise, D.H., 1995. Spiders in ecological webs. Cambridge University Press.

Yarranton, A.G.A, Morrison, R.G., 1974. Spatial dynamics of a primary succession: Nucleation. Journal of Ecology 62, 417-428.

Zimmer, Y., 2010. Competitiveness of rapeseed, soybeans and palm oil. Journal of Oilseed Brassica 1, 8490. 


\section{Appendix}

Table S1: Size class of soil taxa and their mean abundance per $\mathrm{m}^{2}$.

\begin{tabular}{|c|c|c|}
\hline size class & soil taxa & $\begin{array}{c}\text { mean } \\
\text { abundance per } \\
\mathrm{m}^{2} \\
\end{array}$ \\
\hline macrofauna & Annelida & 20 \\
\hline macrofauna & Araneae & 13 \\
\hline macrofauna & Blattodea & 15 \\
\hline macrofauna & Chilopoda & 62 \\
\hline macrofauna & $\begin{array}{l}\text { Coleoptera } \\
\text { (herbivore) }\end{array}$ & 29 \\
\hline macrofauna & Coleoptera (larvae) & 166 \\
\hline macrofauna & $\begin{array}{l}\text { Coleoptera } \\
\text { (predator) }\end{array}$ & 45 \\
\hline macrofauna & Dermaptera & 30 \\
\hline macrofauna & Diplopoda & 223 \\
\hline macrofauna & Diptera & 57 \\
\hline macrofauna & Hirudinea & 10 \\
\hline macrofauna & Hymenoptera & 43 \\
\hline macrofauna & Isopoda & 56 \\
\hline macrofauna & Opiliones & 15 \\
\hline macrofauna & Schizomida & 11 \\
\hline macrofauna & Thysanoptera & 33 \\
\hline mesofauna & Collembola & 1706 \\
\hline mesofauna & Diplura (Campodea) & 32 \\
\hline mesofauna & Diplura (Japygidae) & 88 \\
\hline mesofauna & Mesostigmata & 212 \\
\hline mesofauna & Oribatida & 1339 \\
\hline mesofauna & Protura & 10 \\
\hline mesofauna & Pseudoscorpiones & 29 \\
\hline mesofauna & Psocoptera & 18 \\
\hline mesofauna & Symphyla & 211 \\
\hline
\end{tabular}

Table S2: Size class and numbers of individuals summed up for the four samples taken, i.e. per $1024 \mathrm{~cm}^{2}$. Plot ID, diversity level of planted tree species $(0,1,2,3$ and 6$)$, plot size $(5 \times 5,10 \times 10$, $20 \times 20,40 \times 40$ ) in m, size class (meso-, macrofauna) and number of individuals.

\begin{tabular}{ccccc}
\hline plotID & diversitylevel & plot size in $\mathrm{m}$ & size class & abundance \\
\hline 1 & 1 & $40 \times 40$ & macrofauna & 108 \\
& & & mesofauna & 324 \\
\hline \multirow{2}{*}{2} & 3 & $20 \times 20$ & macrofauna & 41 \\
& & & mesofauna & 226 \\
\hline
\end{tabular}


Chapter IV: Enrichment Project

\begin{tabular}{|c|c|c|c|c|}
\hline \multirow[t]{2}{*}{3} & \multirow[t]{2}{*}{2} & \multirow[t]{2}{*}{$20 \times 20$} & macrofauna & 59 \\
\hline & & & mesofauna & 503 \\
\hline \multirow[t]{2}{*}{4} & \multirow[t]{2}{*}{1} & \multirow[t]{2}{*}{$10 \times 10$} & macrofauna & 45 \\
\hline & & & mesofauna & 723 \\
\hline \multirow[t]{2}{*}{5} & \multirow[t]{2}{*}{1} & \multirow[t]{2}{*}{$40 \times 40$} & macrofauna & 73 \\
\hline & & & mesofauna & 299 \\
\hline \multirow[t]{2}{*}{6} & \multirow[t]{2}{*}{1} & \multirow[t]{2}{*}{$5 \times 5$} & macrofauna & 37 \\
\hline & & & mesofauna & 171 \\
\hline \multirow[t]{2}{*}{7} & \multirow[t]{2}{*}{3} & \multirow[t]{2}{*}{$40 \times 40$} & macrofauna & 23 \\
\hline & & & mesofauna & 183 \\
\hline \multirow[t]{2}{*}{8} & \multirow[t]{2}{*}{1} & \multirow[t]{2}{*}{$5 \times 5$} & macrofauna & 9 \\
\hline & & & mesofauna & 163 \\
\hline \multirow[t]{2}{*}{9} & \multirow[t]{2}{*}{3} & \multirow[t]{2}{*}{$10 \times 10$} & macrofauna & 65 \\
\hline & & & mesofauna & 398 \\
\hline \multirow[t]{2}{*}{10} & \multirow[t]{2}{*}{0} & \multirow[t]{2}{*}{$20 \times 20$} & macrofauna & 91 \\
\hline & & & mesofauna & 292 \\
\hline 11 & 1 & $10 \times 10$ & macrofauna & 10 \\
\hline & & & mesofauna & 65 \\
\hline 12 & 1 & $20 \times 20$ & macrofauna & 42 \\
\hline & & & mesofauna & 303 \\
\hline 13 & 1 & $10 \times 10$ & macrofauna & 28 \\
\hline & & & mesofauna & 710 \\
\hline 14 & 1 & $10 \times 10$ & macrofauna & 74 \\
\hline & & & mesofauna & 535 \\
\hline 15 & 1 & $20 \times 20$ & macrofauna & 55 \\
\hline & & & mesofauna & 403 \\
\hline 16 & 3 & $5 \times 5$ & macrofauna & 23 \\
\hline & & & mesofauna & 426 \\
\hline 17 & 1 & $20 \times 20$ & macrofauna & 90 \\
\hline & & & mesofauna & 455 \\
\hline 18 & 2 & $5 \times 5$ & macrofauna & 28 \\
\hline & & & mesofauna & 301 \\
\hline 19 & 6 & $20 \times 20$ & macrofauna & 21 \\
\hline & & & mesofauna & 80 \\
\hline 20 & 1 & $10 \times 10$ & macrofauna & 52 \\
\hline & & & mesofauna & 235 \\
\hline 21 & 6 & $10 \times 10$ & macrofauna & 36 \\
\hline & & & mesofauna & 597 \\
\hline 22 & 2 & $5 \times 5$ & macrofauna & 90 \\
\hline & & & mesofauna & 258 \\
\hline 23 & 6 & $40 \times 40$ & macrofauna & 28 \\
\hline & & & mesofauna & 402 \\
\hline 24 & 2 & $40 \times 40$ & macrofauna & 37 \\
\hline & & & mesofauna & 421 \\
\hline 25 & 1 & $5 \times 5$ & macrofauna & 30 \\
\hline
\end{tabular}




\begin{tabular}{|c|c|c|c|c|}
\hline & & & mesofauna & 192 \\
\hline \multirow[t]{2}{*}{26} & 2 & $40 \times 40$ & macrofauna & 51 \\
\hline & & & mesofauna & 415 \\
\hline \multirow[t]{2}{*}{27} & 2 & $10 \times 10$ & macrofauna & 41 \\
\hline & & & mesofauna & 363 \\
\hline \multirow[t]{2}{*}{28} & 1 & $5 \times 5$ & macrofauna & 26 \\
\hline & & & mesofauna & 410 \\
\hline \multirow[t]{2}{*}{29} & 3 & $40 \times 40$ & macrofauna & 47 \\
\hline & & & mesofauna & 361 \\
\hline \multirow[t]{2}{*}{30} & 1 & $20 \times 20$ & macrofauna & 15 \\
\hline & & & mesofauna & 93 \\
\hline \multirow[t]{2}{*}{31} & 1 & $5 \times 5$ & macrofauna & 85 \\
\hline & & & mesofauna & 393 \\
\hline \multirow[t]{2}{*}{32} & 2 & $10 \times 10$ & macrofauna & 31 \\
\hline & & & mesofauna & 748 \\
\hline \multirow[t]{2}{*}{33} & 3 & $20 \times 20$ & macrofauna & 21 \\
\hline & & & mesofauna & 333 \\
\hline \multirow[t]{2}{*}{34} & 2 & $10 \times 10$ & macrofauna & 52 \\
\hline & & & mesofauna & 465 \\
\hline \multirow[t]{2}{*}{35} & 0 & $40 \times 40$ & macrofauna & 68 \\
\hline & & & mesofauna & 158 \\
\hline \multirow[t]{2}{*}{36} & 2 & $20 \times 20$ & macrofauna & 73 \\
\hline & & & mesofauna & 487 \\
\hline \multirow[t]{2}{*}{37} & 0 & $10 \times 10$ & macrofauna & 11 \\
\hline & & & mesofauna & 79 \\
\hline \multirow[t]{2}{*}{38} & 1 & $20 \times 20$ & macrofauna & 99 \\
\hline & & & mesofauna & 456 \\
\hline \multirow[t]{2}{*}{39} & 2 & $5 \times 5$ & macrofauna & 44 \\
\hline & & & mesofauna & 502 \\
\hline \multirow[t]{2}{*}{40} & 0 & $5 \times 5$ & macrofauna & 36 \\
\hline & & & mesofauna & 384 \\
\hline \multirow[t]{2}{*}{41} & 1 & $10 \times 10$ & macrofauna & 43 \\
\hline & & & mesofauna & 351 \\
\hline \multirow[t]{2}{*}{42} & 1 & $5 \times 5$ & macrofauna & 21 \\
\hline & & & mesofauna & 338 \\
\hline \multirow[t]{2}{*}{43} & 1 & $40 \times 40$ & macrofauna & 44 \\
\hline & & & mesofauna & 224 \\
\hline \multirow[t]{2}{*}{44} & 3 & $5 \times 5$ & macrofauna & 164 \\
\hline & & & mesofauna & 482 \\
\hline \multirow[t]{2}{*}{45} & 1 & $40 \times 40$ & macrofauna & 68 \\
\hline & & & mesofauna & 260 \\
\hline \multirow[t]{2}{*}{46} & 2 & $40 \times 40$ & macrofauna & 47 \\
\hline & & & mesofauna & 499 \\
\hline \multirow[t]{2}{*}{47} & 2 & $20 \times 20$ & macrofauna & 149 \\
\hline & & & mesofauna & 497 \\
\hline
\end{tabular}




\begin{tabular}{ccccc}
48 & 3 & $10 \times 10$ & $\begin{array}{c}\text { macrofauna } \\
\text { mesofauna }\end{array}$ & $\begin{array}{c}25 \\
366\end{array}$ \\
\hline 49 & 1 & $40 \times 40$ & $\begin{array}{c}\text { macrofauna } \\
\text { mesofauna }\end{array}$ & $\begin{array}{c}45 \\
174\end{array}$ \\
\hline \multirow{2}{*}{50} & 6 & $5 \times 5$ & macrofauna & 12 \\
& & & mesofauna & 343 \\
\hline \multirow{2}{*}{51} & 1 & $20 \times 20$ & macrofauna & 53 \\
& & & mesofauna & 188 \\
\hline \multirow{2}{*}{52} & 1 & $40 \times 40$ & macrofauna & 55 \\
& & & mesofauna & 615
\end{tabular}

Table S3: Mean and standard deviation (sd) of the abundance of macro- and mesofauna per square meter in plots varying in planted tree species $(0,1,2,3$ and 6$)$.

\begin{tabular}{cccc}
\hline diversitylevel & size class & mean $\mathrm{m}^{2}$ & $\mathrm{sd} \mathrm{\textrm {m } ^ { 2 }}$ \\
\hline 0 & macrofauna & 503 & 298 \\
& mesofauna & 2229 & 1151 \\
\hline 1 & macrofauna & 491 & 262 \\
& mesofauna & 3288 & 1713 \\
\hline 2 & macrofauna & 571 & 313 \\
& mesofauna & 4443 & 1159 \\
\hline 3 & macrofauna & 499 & 440 \\
& mesofauna & 3387 & 909 \\
\hline 6 & macrofauna & 237 & 86 \\
& mesofauna & 3472 & 1804
\end{tabular}

Table S4: Mean and standard deviation (sd) of abundance of macro- and mesofauna (size class) per square meter varying with plot size $(5 \times 5,10 \times 10,20 \times 20,40 \times 40 \mathrm{~m})$.

\begin{tabular}{cccc}
\hline plot size in m & size class & mean $\mathrm{m}^{2}$ & $\mathrm{sd} \mathrm{\textrm {m } ^ { 2 }}$ \\
\hline $5 \times 5$ & macrofauna & 454 & 404 \\
& mesofauna & 3277 & 1060 \\
\hline $10 \times 10$ & macrofauna & 385 & 178 \\
& mesofauna & 4233 & 2125 \\
\hline $20 \times 20$ & macrofauna & 608 & 356 \\
& mesofauna & 3242 & 1410 \\
\hline $40 \times 40$ & macrofauna & 521 & 208 \\
& mesofauna & 3256 & 1282
\end{tabular}


Table 55: Variations in mean and standard deviation (sd) of soil invertebrate taxa richness per sampled area $\left(1024 \mathrm{~cm}^{2}\right)$ with diversity level of planted tree species $(0,1,2,3$ and 6$)$.

\begin{tabular}{cccc}
\hline diversit ylevel & size class & $\begin{array}{c}\text { mean taxa per } \\
\text { area sampled }\end{array}$ & $\begin{array}{c}\text { sd taxa per } \\
\text { area sampled }\end{array}$ \\
\hline 0 & macrofauna & 6.50 & 2.50 \\
& mesofauna & 5.75 & 0.83 \\
\hline 1 & macrofauna & 7.88 & 1.79 \\
& mesofauna & 5.42 & 0.81 \\
\hline 2 & macrofauna & 8.67 & 1.11 \\
& mesofauna & 5.33 & 1.11 \\
\hline 3 & macrofauna & 7.38 & 1.22 \\
& mesofauna & 5.13 & 0.60 \\
\hline 6 & macrofauna & 5.00 & 1.87 \\
& mesofauna & 4.75 & 0.43
\end{tabular}

Table S6: Variations in mean and standard deviation (sd) of soil invertebrate taxa richness per sampled area $\left(1024 \mathrm{~cm}^{2}\right)$ with plot size $(5 \times 5,10 \times 10,20 \times 20,40 \times 40 \mathrm{~m})$.

\begin{tabular}{cccc}
\hline diversit ylevel & size class & $\begin{array}{c}\text { mean taxa per } \\
\text { area sampled }\end{array}$ & $\begin{array}{c}\text { sd taxa per } \\
\text { area sampled }\end{array}$ \\
\hline $5 \times 5$ & macrofauna & 7.31 & 2.16 \\
& mesofauna & 5.62 & 0.92 \\
\hline $10 \times 10$ & macrofauna & 7.38 & 2.13 \\
& mesofauna & 5.15 & 0.66 \\
\hline $20 \times 20$ & macrofauna & 8.31 & 1.81 \\
& mesofauna & 5.54 & 1.08 \\
\hline $40 \times 40$ & macrofauna & 7.62 & 1.21 \\
& mesofauna & 5.00 & 0.55
\end{tabular}


Chapter V

\section{General Discussion}

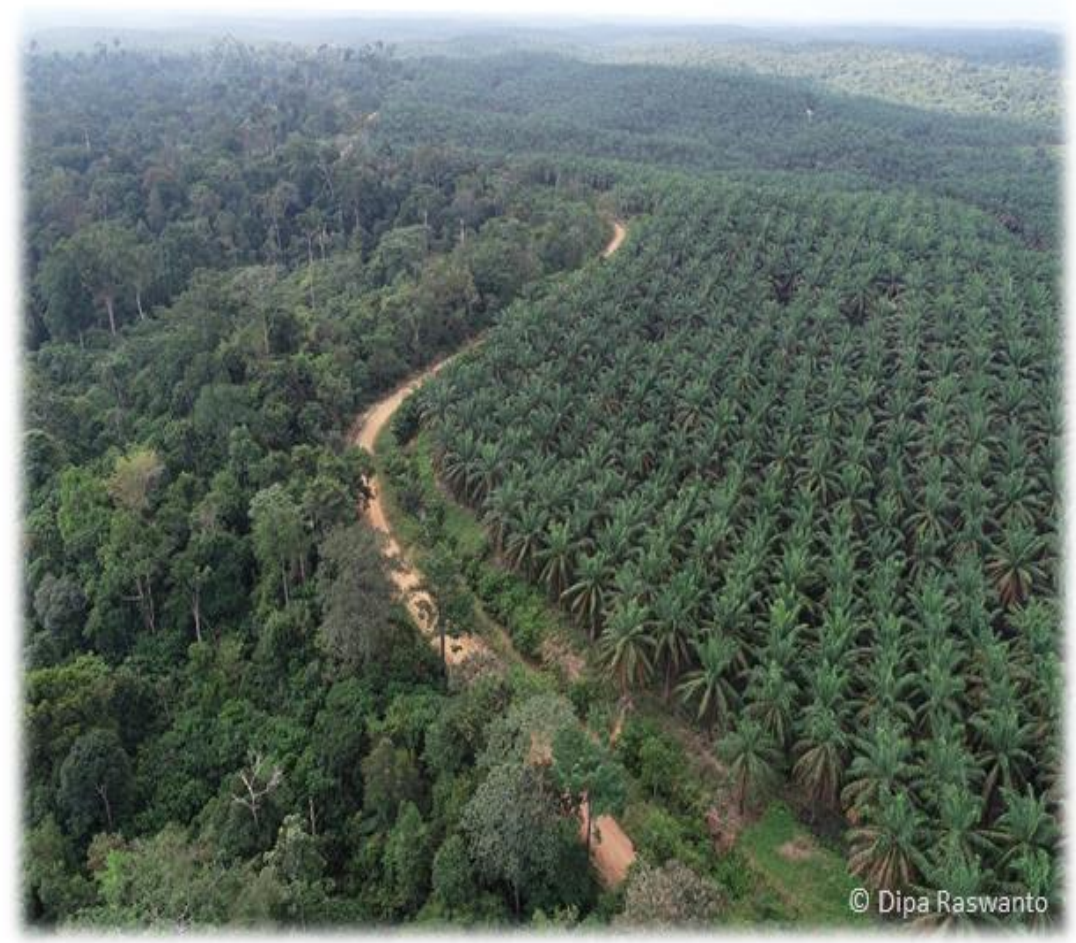



The human population is rapidly growing worldwide and in parallel the demand for food, fuel and fibre (Dirzo and Raven, 2003; Foley et al., 2005; Gibbs et al., 2010; Newbold et al., 2015). Satisfying these demands puts high pressure on ecosystems worldwild (Dirzo and Raven, 2003; Foley et al., 2005; Gibbs et al., 2010; Newbold et al., 2015) and results in increased conversion of natrual ecosystems into plantations as well in more intensively managed production systems (Godfray et al., 2010; Lambin and Meyfroidt, 2011; Tscharntke et al., 2012). In the past decades, especially tropical regions suffered from the transformation of landscapes (Sodhi et al., 2010; Wilcove et al., 2013; Meijide et al., 2018; see Chapter 1). This thesis aimed at improving understanding how the conversion of rainforest and jungle rubber into monoculture plantation systems (rubber and oil palm monoculture plantations) affects soil arthropods, especially oribatid mites and their trophic ecology in tropical lowland regions in South East Asia. The investigated land-use systems represented a gradient of different intensively managed systems, from more natural systems, represented by secondary rainforest and jungle rubber, to intensively managed systems, represented by rubber and oil palm monoculture plantations. Further, we investigated if the enrichment of oil palm plantations with native tree species planted in 'tree islands' of varying tree diversity and plot size beneficially affects soil invertebrates.

In Chapter 2 we investigated shifts in the trophic niches of six soil-living oribatid mite species (Plonaphacarus kugohi, Protoribates paracapucinus, Scheloribates praeincisus, Bischeloribates mahunkai, Rostrozetes cf. shibai, and Rostrozetes sp. 1). Therefore, we measured stable isotope ratios $\left({ }^{13} \mathrm{C} /{ }^{12} \mathrm{C}\right.$ and $\left.{ }^{15} \mathrm{~N} /{ }^{14} \mathrm{~N}\right)$ of single oribatid mite individuals. For three of the six studied species (S. praeincisus, $R$. cf. shibai and Rostrozetes sp. 1) significant shifts of the trophic level (represented by ${ }^{15} \mathrm{~N}$ ) and of the use of basal resources 
(represented by ${ }^{13} \mathrm{C}$ ) were shown, indicating that at least these species change their trophic niches with changing environment. The other three studied species (B. mahunkai, P. kugohi and $P$. paracapucinus) did not differ significantly, however, their trophic shifts followed the same trend. Additionally, the trophic niches of all species separated between more natural systems, i.e. rainforest and jungle rubber, and monoculture plantation systems, i.e. rubber and oil palm plantation. These results contrast earlier studies, which assumed trophic niches of oribatid mite species to be stable and narrow. The investigated oribatid mite species spanned over three trophic levels, including primary and secondary decomposers and predators/scavengers, which is conform to earlier studies (Schneider et al., 2004; Illig et al., 2005; Maraun et al., 2011). Notably, changes in trophic niches of species were due to both changes in the trophic position (indicated by ${ }^{15} \mathrm{~N}$ values) as well as the use of basal resources (indicated by ${ }^{13} \mathrm{C}$ values) with the shifts in transformed ecosystems occurring towards higher tropic levels. This indicates that oribatid mite species switched towards prey of higher trophic levels in converted ecosystems, presumably to animal prey such as nematodes (Heidemann et al., 2011, 2014). Decomposer species were virtually lacking in oil palm plantations, but were also scarce in the other land-use systems, which is conform to another study in tropical ecosystems (Illig et al., 2005). By contrast, higher tropic level species, such as secondary decomposers and predators/scavengers, were present in each of the land-use systems. The scarcity of primary decomposer likely is related to poor litter quality (Butenschoen et al., 2014; Krashevska et al., 2017; Marian et al., 2017) and this is aggravated by the conversion of rainforest into plantation systems (Teuscher et al., 2016; Klarner et al., 2017). In fact, none of the studied oribatid mite species were identified as primary decomposer in plantation systems. Typically soil animals are enriched by $3-4 \delta$ units in ${ }^{13} \mathrm{C}$ compared to litter and this has been termed 
"detrital shift" (Pollierer et al., 2009; Potapov et al., 2019); this also was true in the present study. However, the detrital shift was more pronounced in rainforest and jungle rubber than in monoculture plantations, which likely reflects changes in the usage of plant litter carbon compounds, i.e. form difficult accessible ones with lower $\delta^{13} \mathrm{C}$ values, e.g. lignin, towards easy accessible ones, e.g. sugar and proteins (Gleixner et al., 1993; Hobbie and Werner, 2004; Bowling et al., 2008; Pollierer et al., 2009; Irawan et al., 2019). Additionally, primary decomposer are characterized by low fractionation of ${ }^{15} \mathrm{~N}$, presumably related to "protein sparing", i.e. the retaining of assimilated $\mathrm{N}$ in body tissue rather than excreting it due to low nitrogen supply in litter (Swift et al., 1979; Castellini and Rea, 1992; Gannes et al., 2007; Pollierer et al., 2009). In conclusion, our results indicate that oribatid mites predominantly function as secondary decomposers feeding on microorganisms, in particular fungi, however, they also indicate that in part they feed on animal prey or live as scavengers. Results of this study further indicate that oribatid mite species are able to colonize different ecosystems and this at least in part is due to trophic plasticity and the shift in the use of basal resources with conversion of rainforest into plantation systems.

Chapter 3 investigated shifts in the community-level trophic niche of oribatid mites. Here, we investigated $80 \%$ of oribatid mite communities of rainforest and monoculture plantation systems of oil palm and rubber. Different to the first study, we measured stable isotopes ratios $\left({ }^{13} \mathrm{C} /{ }^{12} \mathrm{C}\right.$ and $\left.{ }^{15} \mathrm{~N} /{ }^{14} \mathrm{~N}\right)$ of pooled individuals. Results of this study confirmed that the community-level trophic niche of oribatid mites is broader in rainforest than in plantation systems. The results further indicated that community-level trophic niche are clearly separated between natural and plantation systems. Further, confirming results of the study presented in Chapter $1,{ }^{15} \mathrm{~N} /{ }^{14} \mathrm{~N}$ ratios indicated that oribatid mites shift their 
diet towards predation and/or scavenging in monoculture plantation systems, presumably due to low amounts and low quality of litter in plantations. Additionally, very low ${ }^{13} \mathrm{C} /{ }^{12} \mathrm{C}$ ratios in rubber plantations indicated that certain oribatid mite species in these systems use resources which do not exist in the other systems. However, the identity of those resources used remained unclear as neither the abundance of algae nor of understory plants is higher in rubber plantations than in the other three land-use systems studied (Rembold et al., 2017; Schulz et al., 2019; Susanti et al., 2019). Additionally, it is unlikely that oribatid mite communities use plant compounds depleted in ${ }^{13} \mathrm{C}$ such as lignin (Bowling et al., 2008; Pollierer et al., 2009), as animals in general are unable to digest lignin (Berg and Ryszard, 2005). However, the results in general suggest that oribatid mite communities in rubber plantations are functionally more diverse than in the other three land-use systems studied. The high uniqueness in oil palm plantations, however, suggested that the loss of species in these systems is associated with a loss of function. Additionally trophic chains in oil palm plantations were shorter as in the other three landuse systems. Again, primary decomposer were lacking supporting the conclusion of the study presented in Chapter 2, that the quality of litter in the studied ecosystems is poor (Butenschoen et al., 2014; Krashevska et al., 2017; Marian et al., 2017). Additionally, parallel to the results presented in Chapter 2, the use of resources of oribatid mite communities changed with changing land-use systems. Changes in the flux of energy trough soil food webs with changes in land-use demonstrate that soil fauna communities are able to respond in a flexible way to changes in the availability of resources (Susanti et al., 2019). The study of Susanti et al. (2019) further indicated that in tropical ecosystems algae play an important role as food resource for Collembola and Oribatida. Similar to the results of Susanti et al. (2019), results of this study indicate that the conversion of 
rainforest into plantation systems likely is associated with the strengthening of the plantbased energy channel in plantation systems. Moreover, high ${ }^{13} \mathrm{C}$ values in rainforest and jungle rubber indicate that in these systems soil food webs are predominantly based on the microbial energy channel (Potapov et al., 2013, 2019). Further, generalist predators, such as Chilopoda, have been shown to switch from decomposer prey to predominantly herbivore prey in monoculture plantations (Klarner et al., 2017). These shifts predominantly were due to reduced or lacking litter layer in plantation systems (Klarner et al., 2017). In natural ecosystems the thickness of the litter layer generally is higher than in plantation systems (Hyodo et al., 2015). As in the study presented in Chapter 2, the trophic niche of communities of oribatid mites differed most between more natural systems, i.e. rainforest and jungle rubber, and monoculture plantations, i.e. rubber and oil palm plantations. ${ }^{13} \mathrm{C}$ and ${ }^{15} \mathrm{~N}$ values further indicated that community-level trophic niches of oribatid mites are similar in more natural ecosystems, and markedly different from those in plantation systems. Notably, oribatid mite communities showed similar trends as in the study presented in Chapter $\mathbf{2}$, indicating that the conversion of rainforest into plantation systems is associated with pronounced shifts in the decomposer system and the channeling of energy trough the decomposer food web.

Results of the first two studies indicated that soil-living oribatid mites are able to adapt to changing environmental conditions with changes in land-use contrasting most species of the aboveground system (Teuscher et al., 2015; Darras et al., 2019). The study presented in Chapter 4 investigated the response of meso- and macrofauna species in 'tree islands' with varying diversity level planted native tree species $(0,1,2,3$ and 6$)$ and plot size ( $5 \mathrm{x}$ 5, $10 \times 10,20 \times 20$ and $40 \times 40 \mathrm{~m}^{2}$ ). Three years after the establishment of the experiment 
we found little evidence that the enrichment of oil palm plantations in 'tree islands' affected the abundance of meso- and macrofauna soil invertebrates. However, the richness of soil invertebrate taxa benefited from 'tree islands' of diversity level 2 . The results contrast earlier studies reporting that a more pronounced understory in plantation systems beneficially impacts aboveground invertebrates (Chung et al., 2000; Ashton-Butt et al., 2018; Spear et al., 2018; Darras et al., 2019). Additionally, bird diversity and bird abundance were increasing with increasing numbers of planted trees at the experimental site (Teuscher et al., 2015). However, it has been demonstrated that the response of belowground organisms to variations in plant diversity generally are less pronounced than the response of aboveground species (Scherber et al., 2010). Another management strategy beneficially affecting aboveground arthropod diversity is Alley-cropping, i.e. planting trees, grasses and/or shrubs into monoculture crop plantations (Gold and Garrett., 2009; Ashraf et al., 2018). Further, arthropod habitat size may be enhanced by increasing the complexity of vegetation and therefore microhabitat diversity (Lawton, 1983; Jose, 2009), which in turn may benefit arthropod diversity. Increased diversity of crop plants and trees might result in an increase in habitat heterogeneity, soil fertility, water quality as well as carbon and nutrient cycling (Fahrig et al., 2011; Torralba et al., 2016; Ashraf et al., 2018). However, decomposer species of grassland ecosystems have been shown to respond to changes in the diversity of plant communities with a delay of four to six years (Eisenhauer et al., 2011). This might explain why we did not find changes in the abundance of macro- and mesofauna three years after establishment of the 'Enrichment experiment'. Additionally, physical habitat characteristics, such as pH and soil porosity, have been assumed to more strongly affect soil communities than plant diversity (Ducarme et al., 2004; Nielsen et al., 2010; Bluhm et al., 2019). Again, changes in physical 
habitat characteristics are slow and might be difficult to detect in short term experiments (Bluhm et al., 2019). Further, the use of herbicides and the associated reduced herb layer in oil palm plantations may affect animal communities (Ismail et al., 2009), even after treatments have has been terminated (Teuscher et al., 2016). However, the enrichment of oil palm plantations with 'tree islands' and the reduced fertilizer and herbicide use likely increased resource availability and habitat diversity. An earlier study at the experimental site demonstrated that aboveground invertebrate species were less affected by 'tree islands' than vertebrate species, such as birds (Teuscher et al., 2016). Presumably, the planted trees and the associated new habitats, and the parallel ceasing of fertilizer and pesticide application exerted positive effects on birds (Tscharntke et al., 2011; Pywell et al., 2012; Teuscher et al., 2016).

Plot size of the 'tree islands' generally did not significantly affect the richness and abundance of soil invertebrate taxa. This is consistent with results of earlier studies demonstrating that species richness and abundance may vary little with island size or connectivity (Brose, 2003; Báldi, 2008; Jonsson et al., 2009). However, in most studies plant diversity and habitat heterogeneity were identified as major drivers of the richness and abundance of species (Báldi, 2008; Jonsson et al., 2009).

The analysis of the community structure showed that taxa associated with diversity level 1 and 2 were mostly decomposers, whereas taxa associated with the other diversity level were mainly predators. It has been shown that the response of belowground animal species to variations in plant species is less pronounced than that of aboveground species (Wardle et al., 2006; Scherber et al., 2010; Eisenhauer et al., 2011). Until now, however, effects of plant species on soil animal species are little understood, but the differential 
response is likely to be related to different traits of plant species in particular those affecting plant litter quality (Díaz et al., 2004; Wardle, 2006).

\section{Conclusions}

Overall, our studies confirmed our hypothesis that at least some oribatid mite species are able to cope with environmental changes in transformed ecosystems by shifting their tropic niches, i.e. by trophic plasticity. Additionally, the community-level trophic niche of oribatid mite changed with changing land-use systems. This, however, contradicted our hypothesis that oribatid mite communities are trophically broader in more natural ecosystems. Especially in rubber plantations oribatid mite communities are functionally diverse and use carbon resources not occurring in the other land use systems studied. The results further indicate that in particular in oil palm plantations the loss of species is associated with a loss of function. Notably, results of the studies presented in Chapter 2 and 3 indicated that changes in the use of basal resources (indicated by ${ }^{13} \mathrm{C}$ ) were more prominent and consistent than those in trophic position (indicated by ${ }^{15} \mathrm{~N}$ ). This suggests that the transformation of rainforest into plantations changes the resource use of soil invertebrate species but in part also their tropic level. Furthermore, it indicates that colonization of different land-use systems by oribatid mites in part is due to trophic plasticity.

Three years after the enrichment of oil palm plantations with 'tree islands' the density and complexity of soil invertebrate communities was little affected. Presumably, this was due to the delayed response of soil invertebrate communities to changes in plant community composition and tree planting. The diversity and abundance of plant communities will 
likely have stronger effects later in time, but this needs further investigation in particular in tropical ecosystems.

\section{References}

Ashraf, M., Zulkifli, R., Sanusi, R., Tohiran, K.A., Terhem, R., Moslim, R., Norhisham, A.R., Ashton-Butt, A., Azhar, B., 2018. Alley-cropping system can boost arthropod biodiversity and ecosystem functions in oil palm. Agriculture, Ecosystems \& Environment 260, 19-26.

Ashton-Butt, A., Aryawan, A.A., Hood, A.S., Naim, M., Purnomo, D., Suhardi, S., Wahyuningsih, R., Willcock, S., Poppy, G.M., Caliman, J., Turner, E.C., Foster, W., Peh, K.S., Snaddon, J.L., 2018. Understory vegetation in oil palm plantations benefits soil biodiversity and decomposition rates. Frontier in Forest and Global Change.

Báldi, A., 2008. Habitat heterogeneity overrides the species-area relationship. Journal of Biogeography 35, 675-681.

Berg, B., Ryszard, L., 2005. Decomposers: Soil microorganisms and animals. Advances in Ecological Research $38,73-100$.

Bluhm, C., Butenschoen, O., Maraun, M., Scheu, S., 2019. Effects of root and leaf litter identity and diversity on oribatid mite abundance, species richness and community composition. PLOS ONE 14, e0219166.

Bowling, D.R., Pataki, D.E., Randerson, J.T., 2008. Carbon isotopes in terrestrial ecosystem pools and $\mathrm{CO}_{2}$ fluxes. New Phytologist 178, 24-40.

Brose, U., 2003. Island biogeography of temporary wetland carabid beetle communities. Journal of Biogeography 30, 879-888.

Butenschoen, O., Krashevska, V., Maraun, M., Marian, F., Sandmann, D., Scheu, S., 2014. Litter mixture effects on decomposition in tropical montane rainforests vary strongly with time and turn negative at later stages of decay. Soil Biology and Biochemistry 77, 121-128.

Castellini, M.A., Rea, L.D., 1992. The biochemistry of natural fasting at its limits. Experientia 48, 575-582.

Chung, A.Y.C., Eggleton, P., Speight, M.R., Hammond, P.M., Chey, V.K., 2000. The diversity of beetle assemblages in different habitat types in Sabah, Malaysia. Bulletin of Entomological Research 90, 475496.

Darras, K., Corre, M.D., Formaglio, G., Tjoa, A., Potapov, A., Sibhatu, K.T., Grass, I., Tscharntke, T., Rubiano, A.A., Buchori, D., Drescher, J., Fardiansah, R., Hölscher, D., Irawan, B., Kneib, T., Krashevska, V., Krause, A., Kreft, H., Li, K., Polle, A., Ryadin, A.R., Rembold, K., Scheu, S., 2019. Reducing fertilizer and avoiding herbicides in oil palm plantations - Ecological and economic valuation. Frontiers in Forests and Global Change 265.

Díaz, S., Hodgson, J.G., Thompson, K., Cabido, M., J.H., C., Jalili, A., Montserrat-Marti, G., Grime, J.P., Zarrinkamar, F., Asri, Y., Band, S.R., 2004. The plant traits that drive ecosystems: Evidence from three continents. Journal of Vegetation Science 15, 295-304. 
Dirzo, R., Raven, P.H., 2003. Global state of biodiversity and loss. Annual Review of Environment and Resources 28, 137-167.

Ducarme, X., André, H.M., Wauthy, G., Lebrun, P., 2004. Are there real endogeic species in temperate forest mites? Pedobiologia 48, 139-147.

Eisenhauer, N., Milcu, A., Sabais, A.C.W., Bessler, H., Brenner, J., Engels, C., Klarner, B., Maraun, M., Partsch, S., Roscher, C., Schonert, F., Temperton, V.M., Thomisch, K., Weigelt, A., Weisser, W.W., Scheu, S., 2011. Plant diversity surpasses plant functional groups and plant productivity as driver of soil biota in the long term. PLOS ONE 6, 15-18.

Fahrig, L., Baudry, J., Brotons, L., Burel, F.G., Crist, T.O., Fuller, R.J., Sirami, C., Siriwardena, G.M., Martin, J.L., 2011. Functional landscape heterogeneity and animal biodiversity in agricultural landscapes. Ecology Letters 14, 101-112.

Foley, J.A., Defries, R., Asner, G.P., Barford, C., Bonan, G., Carpenter, S.R., Chapin, S.F., Coe, M.T., Daily, G.C., Gibbs, H.K., Helkowski, J.H., Holloway, T., Howard, E.A., Kucharik, C.J., Monfreda, C., Patz, J.A., Prentice, C.I., Ramankutty, N., Snyder, P.K., 2005. Global consequences of land use. Science 309, 570574.

Gannes, L.Z., Brien, D.M.O., Martinez, C., Jun, N., 2007. Stable isotopes in animal ecology: Assumptions, caveat, and a call for more laboratory experiments. Ecology 78, 1271-1276.

Gibbs, H.K., Ruesch, A.S., Achard, F., Clayton, M.K., Holmgren, P., Ramankutty, N., Foley, J.A., 2010. Tropical forests were the primary sources of new agricultural land in the 1980s and 1990s. Proceedings of the National Academy of Sciences of the USA 107, 16732-16737.

Gleixner, G., Danier, H.J., Werner, R.A., Schmidt, H.L., 1993. Correlations between the ${ }^{13} \mathrm{C}$ content of primary and secondary plant products in different cell compartments and that in decomposing Basidiomycetes. Plant Physiology 102, 1287-1290.

Godfray, H.C.J., Beddington, J.R., Crute, I.R., Haddad, L., Lawrence, D., Muir, J.F., Pretty, J., Robinson, S., Thomas, S.M., Toulmin, C., 2010. Food Security: The challenge of feeding 9 billion people 327, 812818.

Gold, M.A., Garrett., H.E., 2009. Agroforestry nomenclature, concepts, and practices, in: North American Agroforestry: An Integrated Science and Practice. northamericanag, pp. 45-56.

Heidemann, K., Hennies, A., Schakowske, J., Blumenberg, L., Ruess, L., Scheu, S., Maraun, M., 2014. Freeliving nematodes as prey for higher trophic levels of forest soil food webs. Oikos 123, 1199-1211.

Heidemann, K., Scheu, S., Ruess, L., Maraun, M., 2011. Molecular detection of nematode predation and scavenging in oribatid mites: Laboratory and field experiments. Soil Biology and Biochemistry 43, 2229-2236.

Hobbie, E.A., Werner, R.A., 2004. Bulk carbon isotope patterns in $C_{3}$ and $C_{4}$ plants: $A$ review and synthesis. New Phytologist 161, 371-385.

Hyodo, F., Matsumoto, T., Takematsu, Y., Itioka, T., 2015. Dependence of diverse consumers on detritus in a tropical rain forest food web as revealed by radiocarbon analysis. Functional Ecology 29, 423-429.

Illig, J., Langel, R., Norton, R.A., Scheu, S., Maraun, M., 2005. Where are the decomposers? Uncovering the soil food web of a tropical montane rain forest in southern Ecuador using stable isotopes $\left({ }^{15} \mathrm{~N}\right)$. Journal of Tropical Ecology 21, 589-593. 
Irawan, B., Krashevska, V., Kreft, H., Li, K., Polle, A., Potapov, A., Rembold, K., Scheu, S., Tadesse, K., 2019. Avoiding herbicides and reducing fertilizers in oilpalm plantations - ecological and economic valuations, Frontiers in Forests and Global Change.

Ismail, S., Khasim, N., Omar, Z.R., 2009. Double-row avenue system for crop integration with oil palm. MPOB Information Series 1-4.

Jonsson, M., Yeates, G.W., Wardle, D.A., 2009. Patterns of invertebrate density and taxonomic richness across gradients of area, isolation, and vegetation diversity in a lake-island system. Ecography 32, 963972.

Jose, S., 2009. Agroforestry for ecosystem services and environmental benefits: An overview. Agroforestry Systems 76, 1-10.

Klarner, B., Winkelmann, H., Krashevska, V., Maraun, M., Widyastuti, R., Scheu, S., 2017. Trophic niches, diversity and community composition of invertebrate top predators (Chilopoda) as affected by conversion of tropical lowland rainforest in Sumatra (Indonesia). PLOS ONE 1-17.

Krashevska, V., Sandmann, D., Marian, F., Maraun, M., Scheu, S., 2017. Leaf litter chemistry drives the structure and composition of soil testate amoeba communities in a tropical montane rainforest of the Ecuadorian Andes. Microbial Ecology 74, 681-690.

Lambin, E.F., Meyfroidt, P., 2011. Global land use change, economic globalization, and the looming land scarcity. Proceedings of the National Academy of Sciences of the United States of America 108, 34653472.

Lawton, J.H., 1983. Plant architecture and the diversity of phytophagous insects. Annual Review of Entomology 28, 23-39.

Maraun, M., Erdmann, G., Fischer, B.M., Pollierer, M.M., Norton, R.A., Schneider, K., Scheu, S., 2011. Stable isotopes revisited: Their use and limits for oribatid mite trophic ecology. Soil Biology and Biochemistry 43, 877-882.

Marian, F., Sandmann, D., Krashevska, V., Maraun, M., Scheu, S., 2017. Leaf and root litter decomposition is discontinued at high altitude tropical montane rainforests contributing to carbon sequestration. Ecology and Evolution 7, 6432-6443.

Meijide, A., Badu, C.S., Moyano, F., Tiralla, N., Gunawan, D., Knohl, A., 2018. Impact of forest conversion to oil palm and rubber plantations on microclimate and the role of the 2015 ENSO event. Agricultural and Forest Meteorology 252, 208-2019.

Newbold, T., Hudson, L.N., Hill, S.L.L., Contu, S., Lysenko, I., Senior, R. a., Börger, L., Bennett, D.J., Choimes, A., Collen, B., Day, J., De Palma, A., Díaz, S., Echeverria-Londoño, S., Edgar, M.J., Feldman, A., Garon, M., Harrison, M.L.K., Alhusseini, T., Ingram, D.J., Itescu, Y., Kattge, J., Kemp, V., Kirkpatrick, L., Kleyer, M., Correia, D.L.P., Martin, C.D., Meiri, S., Novosolov, M., Pan, Y., Phillips, H.R.P., Purves, D.W., Robinson, A., Simpson, J., Tuck, S.L., Weiher, E., White, H.J., Ewers, R.M., MacE, G.M., Scharlemann, J.P.W., Purvis, A., 2015. Global effects of land use on local terrestrial biodiversity. Nature 520, 45-50.

Nielsen, U.N., Osler, G.H.R., Campbell, C.D., Neilson, R., Burslem, D.F.R.P., van der Wal, R., 2010. The enigma of soil animal species diversity revisited: The role of small-scale heterogeneity. PLOS ONE 5, 26-28. 
Pollierer, M.M., Langel, R., Scheu, S., Maraun, M., 2009. Compartmentalization of the soil animal food web as indicated by dual analysis of stable isotope ratios $\left({ }^{15} \mathrm{~N} /{ }^{14} \mathrm{~N}\right.$ and $\left.{ }^{13} \mathrm{C} /{ }^{12} \mathrm{C}\right)$. Soil Biology and Biochemistry 41, 1221-1226.

Potapov, A.M., Semenina, E.E., Kurakov, A.V., Tiunov, A.V., 2013. Large ${ }^{13} \mathrm{C} /{ }^{12} \mathrm{C}$ and small ${ }^{15} \mathrm{~N} /{ }^{14} \mathrm{~N}$ isotope fractionation in an experimental detrital foodweb (litter-fungi-collembolans). Ecological Research 28, 1069-1079.

Potapov, A.M., Tiunov, A.V., Scheu, S., 2019. Uncovering trophic positions and food resources of soil animlas using bulk natural stable isotope composition. Biological Reviews 94, 37-59.

Pywell, R.F., Heard, M.S., Bradbury, R.B., Hinsley, S., Nowakowski, M., Walker, K.J., Bullock, J.M., 2012. Wildlife-friendly farming benefits rare birds, bees and plants. Biology Letters 8, 772-775.

Rembold, K., Mangopo, H., Tjitrosoedirdjo, S.S., Kreft, H., 2017. Plant diversity, forest dependency, and alien plant invasions in tropical agricultural landscapes. Biological Conservation 213, 234-242.

Scherber, C., Eisenhauer, N., Weisser, W.W., Schmid, B., Voigt, W., Fischer, M., Schulze, E.D., Roscher, C., Weigelt, A., Allan, E., Beler, H., Bonkowski, M., Buchmann, N., Buscot, F., Clement, L.W., Ebeling, A., Engels, C., Halle, S., Kertscher, I., Klein, A.M., Koller, R., König, S., Kowalski, E., Kummer, V., Kuu, A., Lange, M., Lauterbach, D., Middelhoff, C., Migunova, V.D., Milcu, A., Müller, R., Partsch, S., Petermann, J.S., Renker, C., Rottstock, T., Sabais, A., Scheu, S., Schumacher, J., Temperton, V.M., Tscharntke, T., 2010. Bottom-up effects of plant diversity on multitrophic interactions in a biodiversity experiment. Nature 468, 553-556.

Schneider, K., Migge, S., Norton, R.A., Scheu, S., Langel, R., Reineking, A., Maraun, M., 2004. Trophic niche differentiation in soil microarthropods (Oribatida, Acari): Evidence from stable isotope ratios $\left({ }^{15} \mathrm{~N} /{ }^{14} \mathrm{~N}\right)$. Soil Biology and Biochemistry 36, 1769-1774.

Schulz, G., Schneider, D., Brinkmann, N., Edy, N., Daniel, R., Polle, A., Scheu, S., Krashevska, V., 2019. Changes in trophic groups of protists with conversion of rainforest into rubber and oil palm plantations. Frontiers in Microbiology 10, 1-14.

Sodhi, N.S., Posa, M.R.C., Lee, T.M., Bickford, D., Koh, L.P., Brook, B.W., 2010. The state and conservation of Southeast Asian biodiversity. Biodiversity and Conservation 19, 317-328.

Spear, D.M., Foster, W. a., Advento, A.D., Naim, M., Caliman, J.P., Luke, S.H., Snaddon, J.L., Ps, S., Turner, E.C., 2018. Simplifying understory complexity in oil palm plantations is associated with a reduction in the density of a cleptoparasitic spider, Argyrodes miniaceus (Araneae: Theridiidae), in host (Araneae: Nephilinae) webs. Ecology and Evolution 8, 1595-1603.

Susanti, W.I., Pollierer, M.M., Widyastuti, R., Scheu, S., Potapov, A., 2019. Conversion of rainforest to oil palm and rubber plantations alters energy channels in soil food webs. Ecology and Evolution 1-13.

Swift, M.J., Heal, O.W., Anderson, J.M., 1979. Decomposition in terrestrial ecosystems, Decomposition in terrestrial ecosystems. Univ of California Press.

Teuscher, M., Gérard, A., Brose, U., Buchori, D., Clough, Y., Ehbrecht, M., Hölscher, D., Irawan, B., Sundawati, L., Wollni, M., Kreft, H., 2016. Experimental biodiversity enrichment in oil-palmdominated landscapes in Indonesia. Frontiers in Plant Science 07, 1-15.

Teuscher, M., Vorlaufer, M., Wollni, M., Brose, U., Mulyani, Y., Clough, Y., 2015. Trade-offs between bird diversity and abundance, yields and revenue in smallholder oil palm plantations in Sumatra, Indonesia. Biological Conservation 186, 306-318. 
Torralba, M., Fagerholm, N., Burgess, P.J., Moreno, G., Plieninger, T., 2016. Do European agroforestry systems enhance biodiversity and ecosystem services? A meta-analysis. Agriculture, Ecosystems and Environment 230, 150-161.

Tscharntke, T., Clough, Y., Bhagwat, S.A., Buchori, D., Faust, H., Hertel, D., Hölscher, D., Juhrbandt, J., Kessler, M., Perfecto, I., Scherber, C., Schroth, G., Veldkamp, E., Wanger, T.C., 2011. Multifunctional shade-tree management in tropical agroforestry landscapes - A review. Journal of Applied Ecology 48, 619-629.

Tscharntke, T., Clough, Y., Wanger, T.C., Jackson, L., Motzke, I., Perfecto, I., Vandermeer, J., Whitbread, A., 2012. Global food security, biodiversity conservation and the future of agricultural intensification. Biological Conservation 151, 53-59.

Wardle, D.A., 2006. The influence of biotic interactions on soil biodiversity. Ecology Letters 9, 870-886.

Wardle, D.A., Yeates, G.W., Barker, G.M., Bonner, K.I., 2006. The influence of plant litter diversity on decomposer abundance and diversity. Soil Biology and Biochemistry 38, 1052-1062.

Wilcove, D.S., Giam, X., Edwards, D.P., Fisher, B., Koh, L.P., 2013. Navjot's nightmare revisited: Logging, agriculture, and biodiversity in Southeast Asia. Trends in Ecology and Evolution 28, 531-540. 



\section{Acknowledgments}

Mein erster Dank geht an Mark Maraun. Danke, dass du mir die Möglichkeit gegeben hast Teil dieses Projektes zu sein und mir ermöglich hast meine Liebe für Indonesien zu entdecken. Danke für die vielen Gespräche und dein Fachwissen, was meine Arbeit geformt und bereichert haben. Vielen Danke für die Möglichkeit nach Indonesien zu reisen und dafür, dass du immer ein offenes Ohr hattest für meine Fragen und Probleme.

Ein weiterer großer Dank geht an Stefan Scheu. Danke, dass ich als Teil deiner Arbeitsgruppe die Möglichkeit hatte zu forschen und arbeiten durfte. Danke für alle Gespräche, dein Fachwissen die meine Arbeit vorangebracht und maßgeblich geformt haben. Danke, das du mir die Möglichkeit gegeben hast zum Milbenkurs nach Ohio zu reisen. Danke, dass auch du ein offenes Ohr für Fragen und Probleme hattest und mich immer unterstützt hast.

Danke auch an Marko Rolfs der auch und vor allem in der letzten Zeit unterstützend zur Seite stand.

Danke an meine drei Betreuer, Mark Maraun, Stefan Scheu und Marko Rolfs für die Unterstützung während meiner Promotion und die Verlängerung meiner Studienzeit.

Vielen Dank auch an Barbara Wick, Ivonne Hein, Andrea Lambertz, Aiyen Toja, Mega, Yuking und Rizky, die administrativ immer helfend zur Seite standen, ob hier in Deutschland oder in Indonesien.

Ein ganz besonderer Dank geht an meine Kollegen Melissa Jüds, Anton Potapov, Franca Marian, Dorothee Sandmann und Valentyna Krahevska, für die wunderbaren Kaffeepause, die mitgebrachten Kekse, die schöne Bürozeit und die Unterstützungen sowie 
Ermutigungen und die Ablenkungen, die manchmal einfach nötig waren. Danke dafür, dass ihr immer mit Rat und Tat zur Seite standet und immer ein offenes Ohr hattet, egal was war.

Vielen Dank an all die Mitglieder der AG Scheu für die schöne gemeinsame Zeit, die angenehme Atmosphäre, die gute Zusammenarbeit und die Hilfe. Besonders möchte ich hier nochmal Anton Potapov und Sarah Bluhm danken, die bei statistischen und technischen Problemen da waren.

Besonderen Dank auch an Susanne Böning-Klein, Dora Volvei, Guido Humpert und Dieter Nünchert, die immer helfend zur Seite standen.

Danke an Marisi Italiansia Paulina und Leonarda Situmorang ohne euch wäre Indonesien nicht Indonesien gewesen. Danke für eure Unterstützung vor Ort und die wunderbare Zusammenarbeit. Danke für die gemeinsamen Essenspausen und für all die Sachen bei denen ihr helfend zur Seite standet und für die vielen unvergesslichen Stunden auch außerhalb der Arbeitszeit.

Vielen Danke an all die Kollegen aus dem Efforts-Projekt. Besonderer Dank hierbei geht an die Mitbewohner während meiner Aufenthalte. Danke, dass ihr die Zeit in Indonesien zu einer ganz besonderen und unvergesslichen Zeit gemacht habt. Danke an Jochen Drescher und Dipa Raswanto für die zwei Bilder die ich nutzen durfte für meine Titelbilder.

Danke auch an all die Helfer, die beim vorsortieren der Tiere geholfen haben, sowohl in Indonesien als auch in Deutschland. 
Vielen Dank auch an Cornelia Kurz. Danke, dass du nicht nur mit Rat und Tat zur Seite gestanden hast, sondern auch dass die Zeit in Kassel immer geholfen hat meine Gedanken zu sortieren.

Besonders danken möchte ich auch meinen Freundinnen, Anja Abelmann, Lea Redmann, und Melissa Jüds, die mich seit langer Zeit begleiten und die ich nicht missen möchte. Danke, dass ihr immer da seid und es auch immer sein werdet. Danke, dass ihr immer zugehört habt, geholfen habt und mich abgelenkt habt wenn ich es brauchte. Danke, dass ihr mich auch ohne Worte versteht und in dieser zum Schluss außergewöhnlichen Zeit immer da wart. Danke, dass es keinen Unterschied gemacht hat ob wir dicht beisammen waren oder ob uns 1000 von Kilometer und etliche Stunden getrennt haben. Danke, dass ich immer ich bei euch sein darf!

Mein letzter und größter Dank geht an meine Familie, vor allem an meine Eltern Karin und Peter Krause. Danke, dass ihr immer für mich da seid und mich immer unterstützt. Danke, dass ihr immer nur einen Telefonanruf entfernt seid. Danke, auch vor allem an Mutti, die immer spürt was ich brauch und mich auch ohne Worte versteht. Ohne euch wäre ich heute nicht der Mensch der ich bin. Ein ganz besonderer Dank geht auch an meine Schwester Laura Krause, du bist meine andere Hälfte und gleichst mir wie kein zweiter Mensch. Danke auch an meine Großeltern, die immer da waren. 



\section{List of publications}

Krause A, Pachl P, Schulz G, Lehmitz R, Seniczak A, Schaefer I, Scheu S, Maraun M. 2016. Convergent evolution of aquatic life by sexual and oribatid mites. Experimental and Applied Acarology 70: 439-453.

Pachl P, Lindl A, Krause A, Scheu S, Schaefer I, Maraun M. 2017. The tropics as an ancient cradle of oribatid mite diversity. Acarologia 57: 309-322

Krause A, Sandmann D, Bluhm S L, Ermilov S, Widyastuti R, Farikhah Haneda N, Scheu S, Maraun M. 2019. Shift in trophic niches of soil microarthropods with conversion of tropical rainforest into plantations as indicated by stable isotopes $\left({ }^{15} \mathrm{~N},{ }^{13} \mathrm{C}\right)$. PLOS ONE 14(10): e0224520

Darras K, Corre M D, Formaglio G, Tjoa A, Potapov A, Brambach F, Sibhatu K T, Grass I, Tscharntke T, Rubiano A A, Buchori D, Drescher J, Fardiansah R, Hölscher D, Irawan B, Kneib T, Krashevska V, Krause A, Kreft H, i K, Maraun M, Polle A, Ryadin A R, Rembold K, Scheu S, Tarigan S, Valdés-Uribe A, Yadi S and Veldkamp E. 2019. Reducing fertilizer and avoiding herbicides in oil palm plantations-ecological and economic valuations. Frontiers in Forests and Global Change, 2, 65. 



\section{Thesis declaration}

\section{Declaration of the author's own contribution to manuscripts with multiple authors}

The experiment presented in Chapter $\mathbf{2}$ and $\mathbf{3}$ was set up at the first phase of GermanIndonesian research project "Ecological and socio-economic functions of tropical lowland rainforest transformation systems" (EFForTS) whereas Chapter 4 was set up at the second phase of the EFForTS project. Samples of the experiments in Chapter $\mathbf{2}$ and $\mathbf{3}$ were collected, extracted and exported in the first phase by Bernhard Klarner based on the research permits no. 332/SIP/FRP/SM/IX/2012, 389/SIP/FRP/SM/X/2013 and 145/SIP/FRP/SM/V/2013, collection permit no. S.07/KKH-2/2013 and export permit no. 125/KKH-5/TRP/2014 issued by by the State Ministry of Research and Technology of the Republic of Indonesia (RISTEK), by the Indonesian Ministry of Forestry (PHKA) and issued by the Ministry of Forestry of the Republic of Indonesia. Oribatid mite species were identified by Dorothee Sandmann and Svenja Meyer, Kristina Richter, Anneliese Beckendorff and Melissa Jüds. Samples of the experiments in Chapter 4 were collected, extracted and exported by myself, based on the research permits no. 343/SIP/FRP/E5/Dit.KI/X/2016, collection permit no. S.1006/KKH/SDG/KSA.2/10/2016 and exported on permit no. SK.337/KSDAE/SET/KSA.2/7/2019, issued by the State Ministry of Research and Technology of the Republic of Indonesia (RISTEK), Indonesian Ministry of Forestry (PHKA) and by the Ministry of Forestry of the Republic of Indonesia. Measurements of the stable isotopes were performed by the Kompetenzzentrum Stabile Isotope Göttingen (KOSI). 
I am first author of all manuscripts; I have analyzed the data, written the manuscripts, developed the main ideas, and created tables, figures and appendices. All persons contributing to the manuscripts have been named. All co-authors contributed to finalizing the manuscripts.

The cover-photographs were all taken by me or my colleagues and helpers in Indonesia (see acknowledgments) except for the EM pictures of Oribatida used on the cover page for Chapter 2, which were taken by Mark Maraun under the supervision of Dorothea Hause-Reitner from the Faculty of Geoscience and Geography, University of Göttingen. I confirm that the electronical and printed version of this thesis are identical. 


\section{Plagiarism declaration}

I, Alena Krause, declare that I have written this doctoral thesis independently. All persons contributing to the manuscripts have been named (see above). All sentences or passages quoted from other people's work have been specifically acknowledged by clear crossreferencing.

I have not submitted this thesis in any form for another degree at the university or institution.

Alena Krause

Hamburg, November 2020 



\section{Poster and oral presentation}

Milbenkundliches Kolloquium in Bozen 07.-09.09.2017

Krause A, Pachl P, Schulz G, Lehmitz R, Seniczak A, Schaefer I, Scheu S, Maraun M. 2016. Convergent evolution of aquatic life by sexual and oribatid mites. Experimental and Applied Acarology 70: 439-453. (Talk)

International symposium on socio - ecological transformation of tropical lowland rainforest in Bali 07.-11.10.2018

Krause A, Sandmann D, Bluhm S L, Ermilov S, Widyastuti R, Farikhah Haneda N, Scheu S, Maraun M. 2019. Shift in trophic niches of soil microarthropods with conversion of tropical rainforest into plantations as indicated by stable isotopes $\left({ }^{15} \mathrm{~N},{ }^{13} \mathrm{C}\right.$ ). PLOS ONE $14(10)$ : e0224520 (Talk)

GTÖ conference in Edinburgh 08.-15.04.2019

Krause A, Sandmann D, Bluhm S L, Ermilov S, Widyastuti R, Farikhah Haneda N, Scheu S, Maraun M. 2019. Are soil animals able to change their diet in the changing world? - Changes in trophic niches of oribatid mites with rainforest transformation (Poster) 